\title{
Transitional Justice and Education
}

Engaging Young People in Peacebuilding and Reconciliation 


\section{VÉR Academic}

Open-Access-Publikation im Sinne der CC-Lizenz BY 4.0

(C) 2018, VधR unipress $\mathrm{GmbH}$, Göttingen 


\section{Eckert. Die Schriftenreihe}

\section{Studien des Georg-Eckert-Instituts}

zur internationalen Bildungsmedienforschung

Band 148

Herausgegeben von Eckhardt Fuchs

Redaktion

Wendy Anne Kopisch

Die Reihe ist referiert.

Wissenschaftlicher Beirat

Konrad Jarausch (Chapel Hill/Berlin)

Heidemarie Kemnitz (Braunschweig)

Frank-Olaf Radtke (Frankfurt)

Manfred Rolfes (Potsdam)

Peter Vorderer (Mannheim) 
Clara Ramírez-Barat / Martina Schulze (eds.)

\section{Transitional Justice and Education}

Engaging Young People in Peacebuilding and Reconciliation

With 6 figures

V\& R unipress 
A publication of the Georg Arnhold Program on Education for Sustainable Peace.

The Georg Arnhold Program on Education for Sustainable Peace seeks to bridge the gap between research and practice in peace education, bringing together scholars and practitioners and providing them with a dynamic forum and a worldwide network. The program is a response to the rising demand for sustainable, regionally sensitive, and grassroots approaches to establishing or strengthening a culture of peace and sustainable development through education. Its focus lies particularly on educational media, curricula, policy, and practice at secondary-school level in post-conflict and/or transitional societies.

Henry H. Arnhold instituted the program at the Georg Eckert Institute for International Textbook Research in Braunschweig, Germany, to honor the legacy of his grandfather, Georg Arnhold (1859-1926), a banker, patron of the arts, and committed pacifist.

Bibliografische Information der Deutschen Nationalbibliothek

Die Deutsche Nationalbibliothek verzeichnet diese Publikation in der Deutschen Nationalbibliografie; detaillierte bibliografische Daten sind im Internet über http://dnb.d-nb.de abrufbar.

ISSN 2198-6320

ISBN 978-3-7370-0837-2

Weitere Ausgaben und Online-Angebote sind erhältlich unter: www.v-r.de

○ 2018, V\&R unipress GmbH, Robert-Bosch-Breite 6, D-37079 Göttingen / www.v-r.de Dieses Werk ist als Open-Access-Publikation im Sinne der Creative-Commons-Lizenz BY International 4.0 („Namensnennung“) unter dem DOI 10.14220/9783737008372 abzurufen. Um eine Kopie dieser Lizenz zu sehen, besuchen Sie https://creativecommons.org/licenses/by/4.0/. Jede Verwertung in anderen als den durch diese Lizenz zugelassenen Fällen bedarf der vorherigen schriftlichen Einwilligung des Verlages.

Titelbild: @ Sandra Spitzer 
To Henry H. Arnhold,

dedicated advocate of international dialogue

Open-Access-Publikation im Sinne der CC-Lizenz BY 4.0

(c) 2018, VधR unipress $\mathrm{GmbH}$, Göttingen 
Open-Access-Publikation im Sinne der CC-Lizenz BY 4.0

(c) 2018, V\&R unipress $\mathrm{GmbH}$, Göttingen 


\section{Contents}

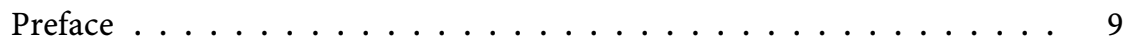

Roger Duthie / Clara Ramírez-Barat

Introduction: Addressing the Educational Legacies of Human Rights

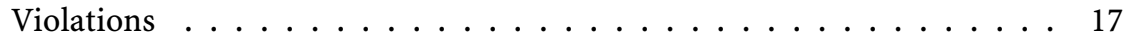

Part I: Designing and Implementing Educational Media and Materials for Transitional Justice

María Andrea Rocha

Creating Classroom Materials: Efforts to Open up a Debate about

Colombia's Armed Conflict . . . . . . . . . . . . . . . . . 45

Denise Bentrovato

Beyond Transitional Justice: Evaluating School Outreach and Educational

Materials in Postwar Rwanda and Sierra Leone . . . . . . . . . . . 67

Najwa Belkziz

Education Reforms in Transitional Justice Contexts: Memory Studies versus Human Rights Education in Morocco _ . . . . . . . . . . . 95

Stefana Fratila

Education for Reconciliation: Transitional Justice in the Aftermath of Canada's Truth and Reconciliation Commission . . . . . . . . . . 117

\section{Part II: Education in Transitional Justice Contexts: Actors and} Practices

Daniel Haumschild

Inappropriate Transgressions: Reanimating Necropolitics via Memorialization in Rwanda . . . . . . . . . . . . . . . . . . 143 
Sara Clarke-Habibi

Insights from Practice: Lessons from Holocaust Education for the

Transitional Justice Classroom . . . . . . . . . . . . . . . . . . 159

Jasmina Brankovic

"People's Power" in the Age of Human Rights: Victims' Contributions to Education in Post-Apartheid South Africa . . . . . . . . . . . . . . . 189

Nadia Siddiqui

At the Frontlines of Education and Peace: Arts-based Storytelling in the

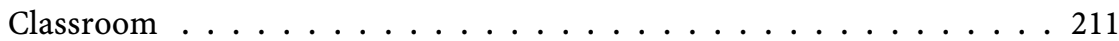

Ties Schelfhout / Ruben Bücking

Building Bridges between Research and Education: The Institute for

Historical Justice and Reconciliation . . . . . . . . . . . . . . . . 229

About the Authors . . . . . . . . . . . . . . . . . . . 249 


\section{Preface}

How the past is remembered, forgotten, or silenced is a highly contentious issue especially in the classroom. Educational media and textbook content,

as the main tools teachers have to develop their classes, speak loudly of how a society chooses to deal with its past and its willingness to strengthen its democracy by breaking with its past of human rights violations. María Andrea Rocha

Centro Nacional de Memoria Histórica, Colombia

This volume, with nine original contributions, owes its existence to the Georg Arnhold International Summer School on Education for Sustainable Peace that took place in June 2015 in Braunschweig, Germany, jointly organized by the Georg Eckert Institute for International Textbook Research (GEI) and the International Center for Transitional Justice (ICTJ). ${ }^{1}$ The Georg Arnhold Program on Education for Sustainable Peace was established at the Georg Eckert Institute in 2013 by Henry H. Arnhold to honor the legacy of his grandfather Georg Arnhold, a committed German pacifist from the city of Dresden, and comprises a guest professorship, an annual summer school and symposium, and focuses on educational media and curricula in post-conflict and transitional societies.

In line with the objectives of the Georg Arnhold Program and following the path set by its first summer school in 2014 on the teaching of history in divided and postwar societies, ${ }^{2}$ the 2015 summer school explored the theme of transitional justice and education. In the aftermath of conflict and mass repression, education has been one of the tools with which different societies have sought to achieve positive transformation. While education has the potential to trigger, maintain and exacerbate conflict, it has also been used to promote a better understanding of the past. It can communicate lessons from past conflicts with a view to advancing reconciliation and peacebuilding, and preventing the recurrence of violence. ${ }^{3}$ With its focus on transitional justice processes and poli-

1 As an academic center of excellence with a unique research library, the GEI conducts research on educational media in their political and social contexts. ICTJ is an international non-profit organization based in New York City specializing in the field of transitional justice. It works to help societies in transition address legacies of massive human rights violations and build civic trust in state institutions as protectors of human rights. For more information, see both centers' websites: www.gei.de and www.ictj.org.

2 The results of that first summer school are collected in a volume entitled History can Bite: History Education in Divided and Postwar Societies, edited by Denise Bentrovato, Karina V. Korostelina, and Martina Schulze (Göttingen: V\&R unipress, 2016).

3 As already noted in the seminal study by Kenneth D. Bush and Diana Saltarelli, education can be a driver of both conflict and peace. See their The Two Faces of Education in Ethnic Conflict: 
cies, our summer school investigated sustainable and context-sensitive grassroots approaches, primarily those delivered through schools, designed to establish or strengthen a culture of peace and advocate values of inclusion and tolerance among children and young people.

In the late 1990s, the concept of transitional justice inspired a new field in practice, policy and academia relating to the set of judicial and non-judicial measures implemented by various countries in times of transition from conflict and/or state repression in order to provide redress for massive human rights abuses. ${ }^{4}$ These measures, which have been prominently supported by international organizations and donor agencies, typically include, although they are not limited to, criminal prosecutions, truth-seeking mechanisms, programs of reparation, memory initiatives, and institutional reforms. Above all, transitional justice strives to provide recognition of the rights of victims, to build civic trust and to strengthen the democratic rule of law. ${ }^{5}$ In creating a bridge between the concepts of transitional justice and education for sustainable peace, our summer school sought to reflect on lessons learned and explore innovative ways to help engage children and youth in justice and peacebuilding efforts through education. Which approaches might foster their capacity for critical thinking and support their civic empowerment while, at the same time, promoting the social cohesion of the societies in which these young people live?

Early-career scholars and long-established academics alike investigated at the summer school how sustainable programs in this area could be supported, how we can mobilize social action toward educative change in post-conflict contexts, and protect informal education initiatives in adverse political climates. Particular emphasis was also placed on measures supporting a conflict-sensitive approach to coming to terms with past violence and repression. In order to promote a varied and rich discussion, the summer school invited original contributions that drew upon diverse contexts, theories and methods to shed new light on various topics, including curricula and curriculum reform, teaching tools and media, and educational activities. Attention was also paid to the roles played by diverse actors such as teachers, NGOs, international organizations,

Towards a Peacebuilding Education for Children (Florence: UNICEF Innocenti Research Centre, 2002). See also Alan Smith and Tony Vaux, Education, Conflict and International Development (London: DIFD, 2003); and Lynn Davies, Education and Conflict: Complexity and Chaos (London: Routledge, 2003).

4 Seminal works in this respect include Neil J. Kritz (ed.) Transitional Justice (Washington D.C.: United States Institute of Peace Press, 1995), James A. McAdams (ed.) Transitional Justice and the Rule of Law in New Democracies (Notre Dame: University of Notre Dame Press, 1997); and Ruti Teitel, Transitional Justice (New York: Oxford University Press, 2000).

5 For a theoretical account of the concept, see Pablo de Greiff, "Theorizing Transitional Justice," in Nomos LI: Transitional Justice, ed. Melissa Williams et al. (New York: NYU Press, 2012), 31-77. 
communities and governments in the context of transitional justice processes. The discussion was guided by, and not restricted to, the following issues and research questions.

\section{Conflict-sensitive curricula and curriculum reform as part of transitional justice policies}

- Which school subjects and educational levels can incorporate a transitional justice perspective? Which roles can curricula play in the exacerbation of conflict and human rights abuses, and how can the effects of conflict be addressed in curricula?

- What are the objectives of curricula reform from a transitional justice perspective and which strategies and challenges should be considered in their implementation?

- How can transitional justice measures, including truth commissions, trials and efforts to uphold the memory of atrocities and their victims, influence curriculum reform?

- How can curriculum reform contribute to, or hinder, achieving the objectives of transitional justice, including redress for atrocities, the prevention of future abuses, accountability, and reconciliation?

\section{Educational media and materials}

- What is the potential of educational media such as textbooks and other publications for children to contribute to achieving the objectives of transitional justice processes, such as building a culture of democratic citizenship and respect for human rights, and ensuring the non-recurrence of conflict and human rights violations?

- How can materials produced by transitional justice institutions be converted into educational media? How should these be designed and used in order to cater for children?

- How can topics related to transitional justice be incorporated into and presented in textbooks? Which methodologies and learning objectives should be pursued or have proved successful? 


\section{Educational activities in the context of transitional justice processes}

- What educational outreach activities led by transitional justice institutions or civil society organizations in schools can be considered innovative and successful?

- How can educational programs revolving around memorials, memorial museums, libraries, cultural institutions etc. in the aftermath of conflict and human rights violations contribute to engaging children and youth in justice and peacebuilding efforts?

- How can informal educational initiatives in transitional justice be linked with formal education systems in order to ensure their sustainability?

\section{Involving and coordinating stakeholders in transitional justice and education programs}

- How might teachers, teacher training and teaching methods make a difference in promoting redress, inclusion, tolerance, and peace?

- How can transitional justice-related educational materials be used in the classroom? What might be the main challenges in doing so?

- What are the roles and experiences of such actors as NGOs, UN bodies, governments and communities in the field of education in transitional justice contexts? What impact have they had in attempting to link education, justice and peacebuilding?

The week-long summer school brought together 17 early-career scholars and practitioners from Africa, Asia, Europe, and North America and eight senior scholars and practitioners from Argentina, Canada, Colombia, Italy, South Africa, Spain, the United Kingdom, and the United States, each of them with extensive experience in the field of transitional justice and education. The experts were: Mario Novelli, Professor of the Political Economy of Education at the University of Sussex, who gave the keynote address; Elena Bergonzini, an educator at the Monte Sole Peace School in Italy who led a workshop on the Monte Sole Peace School's educational programs; Roger Duthie, Senior Associate in the Research Unit at ICTJ, who led the panel on "Educational Activities in the Context of Transitional Justice Processes;" Roy Hellenberg, Deputy Headmaster at Durban High School in South Africa, who chaired the panel on "Involving and Coordinating Stakeholders in Transitional Justice and Education Programs"; María Andrea Rocha who is part of the pedagogical team of the Centro Nacional de Memoria Histórica (National Center for Historical Memory) in Bogotá and 
who led the panel on educational media and materials, introducing Colombian efforts to build classroom materials to open a debate about a violent past; Ana María Rodino, a Senior Researcher at the National Distance University in Costa Rica and Lecturer at the University of La Plata and the University of Buenos Aires in Argentina, who chaired the panel on "Conflict-sensitive Curricula and Curriculum Reform as Part of Transitional Justice Policies"; and Susan Shepler, Associate Professor of International Peace and Conflict Resolution at American University in Washington, DC, and Georg Arnhold Visiting Research Professor 2015, who conducted a workshop on the use of ethnography in studies of Transitional Justice and education.

The summer school thus provided a space for learning different approaches and perspectives, but also recognizing similar themes, objectives, and challenges that arise working in this relatively new but rapidly evolving field. Despite working in different regions, fields, and approaches, nearly every participant encountered similar obstacles and risks in their work, an encouraging reminder that they were not the only ones dealing with the delicate challenge of promoting justice and peace in educational curricula and materials.

The key question of this volume revolves around the role and importance of education in transitional justice processes. As the mission statement of the Georg Eckert Institute ascertains: "Education is the cornerstone of our future in the societies we live in. As an academic institute, we are dedicated to ensuring that future generations are brought up with open minds, able to reflect on their attitudes and beliefs and embrace responsibility and democracy." ${ }^{\prime 6}$ In the aftermath of conflict or after years of authoritarianism, education, precisely because of the role it plays in building the future of societies, can play a unique role in the peacebuilding process. As a recent report from ICTJ recognizes, "the contribution that education can make to peace depends not only on measures such as the physical reconstruction of schools, the reincorporation of young people into the education system, and school curricula that promote universal values of tolerance and social cohesion, but also on the sensitivity of reforms and programs to the legacies of past injustices in the education sector itself and the public culture of a country."7

For Mario Novelli, the role education can play in the area of peacebuilding should take into account this act of looking back into the past:

I believe in peace with social justice, and that requires more than just the cessation of violence. It necessitates truth, justice and reparations for the victims - which is central

6 Mission statement, Georg Eckert Institute for International Textbook Research, http://www. gei.de/en/the-institute/mission-statement.html, accessed 14 September 2016.

7 Ramírez-Barat, Clara and Roger Duthie, Education and Transitional Justice: Opportunities and Challenges for Peacebuilding (New York: ICTJ, 2015), 1. 
to the transitional justice agenda. That is at the heart of the idea of transitional justice and education can play an important part in that process. It can educate people about their country's difficult past, it can bring communities together and it can also offer people an alternative path from violence. It can, of course, also do the very opposite, so it is important that education systems are brought into the peacebuilding debate. ${ }^{8}$

According to Novelli, while education has received increased attention from the international community over the past two decades, it has only played a minor role for the United Nations as well as in international peacebuilding approaches. For Novelli, education systems and interventions need to first and foremost address the original causes of conflicts and should focus more on structural and systemic opportunities as well as on conflict-sensitive and "more robust" approaches. He has introduced an analytical framework that he developed with colleagues from the Universities of Amsterdam, Ulster and Sussex and calls the "4 Rs Analytical Approach" (Redistribution, Recognition, Representation and Reconciliation) and that "can offer a more robust approach for analyzing, promoting and strengthening education's role in supporting and promoting peace with social justice - a form of 'positive peace' that can better contribute to longterm and sustainable peacebuilding in conflict affected contexts." ${ }^{10} \mathrm{He}$ has also voiced criticism of what he calls "mainstream peace education" and instead argued for the term "peacebuilding education":

Much peace education focuses too much on interpersonal aspects and as a result tends to avoid addressing the structural factors that underpin most conflicts, that is, the grievances that people have. Palestinians do not need peace education; they need human rights and dignity. Peacebuilding education on the other hand seeks to address the education system more holistically looking at the governance, funding, coordination of the education system as well as the curriculum and issues of pedagogy. It seeks to promote a more socially just system that can work to support the restoration of human rights and dignity of marginalized populations. ${ }^{11}$

The principal claim developed in a variety of ways in the different chapters of this book is that, when considering the contribution made by transitional justice to the peacebuilding agenda, we also need to pay attention to the specific role that

8 Interview with Mario Novelli, "Education for Sustainable Peace: News from the Georg Arnhold Program in 2015," Eckert Bulletin 15, 54.

9 See Mario Novelli, Mieke Lopes Cardozo, and Alan Smith, Theoretical Framework for Analysing the Contribution of Education to Sustainable Peacebuilding: 4Rs in Conflict Affected Contexts (Amsterdam: University of Amsterdam, 2015).

10 Mario Novelli, "Education, Peace \& Social Justice in Conflict-Affected Contexts: Beyond Negative Peace and Peace Education," Keynote Speech, Second Georg Arnhold International Summer School, 2015. See also Mario Novelli and Mieke T.A. Lopes Cardozo, "Conflict, Education and the Global South: New Critical Directions," International Journal of Educational Development 28 (2008): 473-488.

11 Interview with Mario Novelli (as above). 
education can play in this process. Traditionally, peace education focuses on the future, whereas a transitional justice perspective also considers the past. It acknowledges that, in building a different society, one must first examine and address past injustices and conflictive structures and dynamics. Considering the role that education plays in shaping social values and norms, legacies of conflict and repression in the educational system can involve significant and long-lasting negative effects. These often go beyond the destruction of infrastructure, material resources and a lack of school personnel to include the emotional effects of conflict in children and educators, the persistence of a culture of impunity and violence, and intergenerational trauma. Such contexts are frequently characterized by deeply conflictual narratives and social divisions.

In this respect, the legacy of conflict not only has significant effects on the education system alone; it can also have long-term impacts on the transmission of memory. In the aftermath of conflict, societies urgently need to rebuild their public culture. Indeed, focusing their intervention primarily on the institutional realm, the longer-term impact of transitional justice processes depends on their capacity to transform a previous culture of impunity, division and conflict into one of respect for the democratic rule of law and human rights. Education can be a fundamental vehicle in achieving these goals by fostering a longer-term continuity for the values and principles instituted through transitional justice processes. For Julia Paulson, education can importantly contribute to reinforcing some of the goals of transitional justice processes, "when transitional justice measures engage children and youth and their particular experiences of the past, and when transitional justice measures address the education system, its role in the past, and its (re)creation as something new." ${ }^{12}$ As such, after violent conflict, in many cases such reform is necessary to guarantee that the education system properly fulfills its role in a democracy; that is, to educate informed and critical citizens within a broader culture of participation and defense of human rights.

It remains for us to acknowledge here the numerous institutions and people that made both the summer school and this volume possible. First, we are deeply thankful to Henry H. Arnhold and his strong belief in the role education can play in building more just and peaceful societies. We also thank the members of the Academic Advisory Board of the Georg Arnhold Program for their support and strong interest in transitional justice and education. We are grateful to the Georg Eckert Institute and to the International Center of Transitional Justice for their roles in putting together the event, particularly to Michael Annegarn-Gläß, Denise Bentrovato, Roger Duthie, Maik Fiedler, Jakob Kirchheimer, Inga Nie-

12 Julia Paulson, (Re)Creating Education in Postconflict Contexts: Transitional Justice, Education, and Human Development (New York: International Center for Transitional Justice, November 2009), 13. 
haus, Imke Rath, Roman Richtera, and Zrinka Štimac. We also would like to thank Matthew Parkes and Lucy Taylor, the 2015 and 2016 interns of the Georg Arnhold Program, for their invaluable support. For their encouragement and for many lively and engaging discussions we further warmly thank Erna Anjarwati, Najwa Belkziz, Denise Bentrovato, Elena Bergonzini, Jasmina Brankovic, Sara Clarke-Habibi, Roger Duthie, Stefana Fratila, Judith Geerling, Rachel Goodmann, Daniel Haumschild, Roy Hellenberg, Julius O. Jwan, Jakob Kirchheimer, Vincent Lungwitz, Munini Mutuku, Mario Novelli, María Andrea Rocha, Ana María Rodino, Susan Shepler, Nadia Siddiqui, Marijana Toma, and Nathaniel Umukoro.

Clara Ramírez-Barat and Martina Schulze São Paulo and Hamburg, November 2017 


\section{Introduction: Addressing the Educational Legacies of Human Rights Violations}

The relationship between education and conflict has recently received increased attention in the fields of education and peacebuilding, particularly around the impact of conflict on education and the ways in which education can both trigger conflict and contribute to peace. ${ }^{1}$ Most work on education reconstruction after periods of conflict or authoritarianism has taken a development or peacebuilding perspective given the clear role that education can play in promoting socioeconomic development and preventing the recurrence of armed violence or repression. Less attention has been paid to the specific educational legacies of repression and human rights violations, especially where education has been used to exacerbate divisions or to discriminate against groups for ideological purposes, or where conflict has resulted in lost educational opportunities for children. The contribution that education can make to peace, however, depends not only on measures such as the physical reconstruction of schools, the reincorporation of young people into the education system, and school curricula that promote universal values of tolerance and social cohesion, but also on the sensitivity of reforms and programs to the legacies of past injustices in the education sector itself. $^{2}$

Transitional justice, understood as judicial and non-judicial measures that seek to promote accountability and redress for massive violations of human

1 See, for example, Kenneth D. Bush and Diana Saltarelli, The Two Faces of Education in Ethnic Conflict: Towards a Peacebuilding Education for Children (Florence: UNICEF Innocenti Research Centre, 2002); Alan Smith and Tony Vaux, Education, Conflict and International Development (London: DIFD, 2003); Lynn Davies, Education and Conflict: Complexity and Chaos (London: Routledge, 2003); Sobhi Tawil and Alexandra Harley, eds., Education, Conflict and Social Cohesion (Geneva: International Bureau of Education/UNESCO, 2004); and Peter Buckland, Reshaping the Future: Education and Post-conflict Reconstruction (Washington, D.C.: World Bank, 2004).

2 For a longer report, see Clara Ramírez-Barat and Roger Duthie, "Education and Transitional Justice: Opportunities and Challenges for Peacebuilding" (New York: ICTJ/UNICEF, 2015), which was a final product of a two-year research project conducted by ICTJ in collaboration with UNICEF. 
rights, is increasingly recognized as a fundamental aspect of peacebuilding efforts. ${ }^{3}$ To the extent that it provides recognition for victims and helps to restore civic trust in state institutions and among citizens, transitional justice can help to strengthen the rule of law, address grievances among affected communities, and prevent the recurrence of violations. ${ }^{4}$ This introductory chapter sets out initial reflections as to how a transitional justice framework can play an important role in identifying educational deficits related to the logic of past conflict and repression and informing the reconstruction of the education sector. It also examines how education can facilitate and sustain the work of transitional justice measures, considering both post-conflict and post-authoritarian contexts. It should be noted that, while there is an emerging literature at the intersection of transitional justice and education, to date this literature has mainly focused on aspects of teaching the violent past in the classroom, importantly understood as an issue for history education. ${ }^{5}$ However, our claim here is that, beyond that important aspect, which is very much linked to issues surrounding the inter-

3 See the working draft, Guidance on Evaluating Conflict Prevention and Peacebuilding Activities, by the OECD and DAC (Paris: OECD Publishing, 2008), which expanded the "Utstein Palette" to include transitional justice under its pillar of building a "Culture of Truth, Justice and Reconciliation"; United Nations, Guidance Note of the Secretary General: United Nations Approach to Transitional Justice (New York: UN, 2010), 3; and Camino Kavanagh and Bruce Jones, Shaky Foundations: An Assessment of the UN's Rule of Law Support Agenda (New York: New York University/Center on International Cooperation, 2011), 13.

4 For a theoretical account of how transitional justice can make this contribution, see Pablo de Greiff, “Theorizing Transitional Justice," Nomos 51 (2012): 31-77.

5 The seminal work in the field is Elizabeth A. Cole, ed., Teaching the Violent Past: History Education and Reconciliation (New York: Roman \& Littlefield, 2007). See also Julia Paulson, ed., Education and Reconciliation: Exploring Conflict and Post-Conflict Situations (London: Bloomsbury, 2011); Michelle J. Bellino, Julia Paulson, and Elizabeth Anderson Worden, "Working Through Difficult Pasts: Democracy and Transitional Justice in Education," Comparative Education 53 (2017): 313-332, introducing a special issue on the topic; and Clara Ramírez-Barat and Roger Duthie, eds., Transitional Justice and Education: Learning Peace (New York: SSRC, 2017). Other contributions to this discussion, mostly focusing on specific case studies, include Alan Smith, "Education in the Twenty-First Century: Conflict, Reconstruction and Reconciliation," Compare 35 (2005): 373-391; Julia Paulson, "The Educational Recommendations of Truth and Reconciliation Commissions: Potential and Practice in Sierra Leone," Research in Comparative and International Education 1 (2006): 335-350; Harvey M. Weinstein et al., "School Voices: Challenges Facing Education Systems after Identity-based Conflicts," Education, Citizenship and Social Justice 2 (2007): 41-71; Alan McCully, "History Teaching, Conflict and the Legacy of the Past," Education, Citizenship and Social Justice 7 (2012): 145-159; Denise Bentrovato, "Accounting for Genocide: Transitional Justice, Mass (Re)education and the Pedagogy of Truth in Present-day Rwanda," Comparative Education 53 (2017):396-410; and Clare Magill, Alan Smith, and Brandon Hamber, The Role of Education in Reconciliation (Ulster: University of Ulster, 2009). It should also be noted that the most notable and varied literature on the topic has been written in Spanish, as part of the work of numerous authors within what has been called "la pedagogía de la memoria." 
generational transmission of memory, the education system should be treated, as a whole, as an area of institutional reform from a transitional justice perspective.

To establish an initial relationship between education and transitional justice, the first section of this introduction briefly discusses these two areas as separate but related elements of societal responses to injustices associated with massive human rights violations, and the potential contribution of synergies between the two fields to establishing sustainable peace and preventing the recurrence of atrocities. The second section maps out the different elements of education reconstruction in which a transitional justice framework can make a difference, including curricula reform, increased access to education, school culture and governance, pedagogy, teaching tools, and teacher capacity and training. The third section highlights the various actors who can play a part in linking transitional justice and education, including transitional justice bodies, civil society groups, school communities, and government, each of which can be either an agent of change or an obstacle to it. The fourth section examines the more capacity- and resource-based constraints that efforts to address the past through education are likely to face. The concluding section emphasizes the importance of identifying opportunities for change while maintaining realistic expectations regarding the change that can actually be achieved.

\section{A Transitional Justice Approach to Education}

During periods of violent conflict and repression, there is often a connection between human rights violations and the provision of education. The result is often an educational deficit. Such violations may not be merely the indirect impact of conflict, but rather part of an intentional and systematic attempt to deprive children and young people of schooling and to manipulate and distort teachers and textbooks to legitimize repression and reproduce patterns of violence. ${ }^{6}$ The closure and destruction of schools, for example, has often been used "as a weapon of war to erode civilian support processes and punish insurgents in ways that will compromise irremediably the future of their families and ethnic groups," or "as a weapon of cultural repression of minorities, denying them access to education, or using education to suppress their language, traditions, art forms, religious practices and cultural values." ${ }^{8}$ Furthermore, repressive political systems have used education policies to shape or reinforce social divisions,

6 See Graça Machel, The Impact of Conflict on Children, A/51/302, August 26, 1996; UN Security Council Resolution 1612, 26 July, 2005; see more on this at the website of the Global Coalition to Protect Education from Attack, www.protectingeducation.org, accessed 5 February 2018.

7 Bush and Saltarelli, The Two Faces of Education, 11.

8 Smith and Vaux, Education, Conflict and International Development, 18. 
intolerance, and inequality, or to eliminate spaces for the development of a critical citizenship.

Because of education's important social role, legacies of conflict and repression in the educational system can have significant, long-lasting impacts on individuals and societies. Their negative effects on individuals can be psychological, impairing capacities for empowerment and resilience; economic, for instance due to reduced employment opportunities; and political, considering that "many children leave school with a profound distrust of the institutions of the state in which they live and, because of the poor quality of the education they have received, they are particularly susceptible to the machinations of ethnic mobilizers." "Violations with an impact on education can also have significant social repercussions: attacks on schools and the manipulation of education for political purposes affect not only individuals but also the larger communities and societies. Legacies of abuse related to the development of a culture of violence and impunity can have long-term impacts on social patterns in the transmission of memory. As Gail Weldon has argued, the legacies of conflict "not only shape the way in which the new social order is conceived, but also the ways in which traumatic knowledge is passed on from one generation to another." 10

When understood as part of a societal response to the legacies of past abuses, however, education can be aligned with the aims of transitional justice. It can engage society, especially the younger generations, in a dialogue on the importance of dealing with the past. It can address the impact of violations on education, and accordingly help to reform the education system from a perspective informed by a respect for human rights and the democratic rule of law. This can be an important indicator of the new government's commitment to the recognition and non-repetition of the past, adding an extra layer of complexity to the peacebuilding agenda. A transitional justice framework, for its part, can play an important role in identifying educational deficits related to previous repressive or conflictive logic and in informing the reconstruction of the education sector via renewed social values. More importantly, it can contribute to contextualizing the aims of education reconstruction within a particular history of abuses, with an eye to strengthening its potential for preventing future violence from recurring. ${ }^{11}$

9 Bush and Saltarelli, The Two Faces of Education, 16.

10 Gail Weldon, "Conflict, Identity and Intergenerational Transmission of Memory," presentation at ICTJ Transitional Justice and Education Roundtable (New York, October 2014), 2.

11 Lynn Davies, "The Power of a Transitional Justice Approach to Education: Post-Conflict Education Reconstruction and Transitional Justice," ICTJ Studies on Education and Transitional Justice (New York: ICTJ, 2017). 


\section{Transitional Justice and the Reconstruction of Education}

A transitional justice framework - usually understood to include measures of criminal justice, truth-seeking efforts, institutional reform, and reparations ${ }^{12}$ can play a valuable role in promoting reforms that contribute more effectively to modifying patterns that have fueled conflict in the past, especially in relation to exclusionary and authoritarian practices in a school system. Truth-seeking efforts and criminal proceedings in particular can develop new narratives that promote a critical approach to history and the recognition of victims' rights, which can later be included in the national school curricula or used in informal educational venues. At the same time, access to educational measures, when properly articulated in relation to the past conflict, can be a form of reparation for those who lost educational opportunities as a consequence of human rights violations. Finally, education can itself be reformed within a transitional justice framework, with the aim of reinforcing norms and values based on respect for human rights. This section explores some of the specific areas within the education system in which a transitional justice approach can make a difference.

Norms and Institutions

A first step in changing the education system is a review of existing norms and policies with the aim of removing all harmful remnants of the previous repressive logic. This process should importantly be contextualized, with an assessment in each case of exactly how the past affected education. Depending on each context, a revision of the system in place can lead either to the reform of educational institutions or to the creation of new ones; the revision of laws that guarantee the right to education for all as well as the rights of teachers and educators; the removal of personnel who abused human rights from key positions; and the restitution of teachers and administrators who were dismissed unfairly by the previous regime. ${ }^{13}$ Indeed, truth commissions and criminal trials have on occasion produced findings regarding the role of education in repression and conflict, on which they have based their recommendations for education reform. The truth commission in Peru, for example, identified the education sector as

12 See, for example, Clara Sandoval, "Transitional Justice and Social Change," SUR International Journal on Human Rights 20 (2014): 181-193.

13 See Julia Paulson, "(Re)Creating Education in Postconflict Contexts: Transitional Justice, Education, and Human Development" (New York: ICTJ, 2009), 22-23; Christiane Wilke, "The Shield, the Sword and the Party: Vetting the East German Public Sector," in Justice as Prevention: Vetting Public Employees in Transitional Societies, edited by Alexander MayerRieckh and Pablo de Greiff (New York: SSRC, 2009). 
one of four essential areas requiring reform, devoting a whole chapter to the topic and focusing its recommendations on promoting respect for human rights and sociocultural differences in order to build a new national vision for education. ${ }^{14}$ A recent study of 20 truth commissions importantly noted an increasing engagement with education over time; however, it also found that the commissions' forward-looking recommendations tended to be hindered in their impact due to their inadequate grounding in backward-looking analyses of the role of education in conflict and injustice. ${ }^{15}$

When reforming norms and institutions within education systems, it is equally important to address aspects of segregation among different groups, a common structural legacy of past human rights violations. Many transitional societies, such as Bosnia-Herzegovina and Northern Ireland, retain educational institutions that are deeply segregated, often mirroring broader sociopolitical norms that are still in place. This is particularly true of cases where conflict or repression has had an identity-related dimension. While segregation can be a reflection of identity and other social divisions, it can also be part of an explicit policy of privileging one group over another. The persistence of segregated schools in the public system can contribute to reinforcing divisions and exacerbating tensions - by perpetuating stereotypes and prejudices - and hindering progress made by other initiatives designed to promote acknowledgment and build civic trust. As Karen Murphy argues, "[d]iversity, in a formerly segregated society, could be viewed as a just goal and one that aims to not just bring people together across communities but also to provide more equal opportunities and access to resources across communities."

\section{Access to Education}

While access to free primary education is an established human right, ${ }^{17}$ during conflict and under repressive regimes it is common for children and young

14 Comisión de la Verdad y la Reconciliación del Perú, "Recomendaciones," in Informe Final, vol. IX (Lima: Comisión de la Verdad y la Reconciliación del Perú, 2003), 137-138. See also Julia Paulson, "Truth Commissions and National Curricula: The Case of Recordándonos in Peru," in Children and Transitional Justice: Truth-Telling, Accountability and Reconciliation, edited by Sharanjeet Parmar et al. (Cambridge: Harvard Law School and UNICEF, 2010), 327-364.

15 Julia Paulson and Michelle J. Bellino, "Truth Commissions, Education, and Positive Peace: An Analysis of Truth Commission Final Reports (1980-2015)," Comparative Education 53 (2017): 313-332.

16 Karen Murphy, "Educational Reform through a Transitional Justice Lens: The Ambivalent Transitions of Bosnia and Northern Ireland," in Transitional Justice and Education, 69.

17 See Art. 13.2 of the International Covenant on Economic, Social and Cultural Rights, General 
people to have limited or no access to schooling or to be denied quality education. If the provision of education as a state social policy returns to more normal levels during a transition, using reparative justice policies as a mechanism to foster access to education for individuals who were previously excluded or to facilitate the completion of studies for those whose education was interrupted can be a way of acknowledging the educational impact of repressive policies and human rights violations. If education as a form of reparation specifically helps victims to overcome obstacles to education that resulted from rights violations, ${ }^{18}$ it may contribute to "reducing inequality, particularly in cases in which victims tend to be from socioeconomically disadvantaged groups." ${ }^{19}$ Education as a form of reparation must go beyond what the state is already obligated to provide, however, by acknowledging as unjust the harm endured by children and young people as rights-bearers, or by their communities.

Administrative reparation programs, which provide material and symbolic benefits to both individual and collective victims, have been proposed or implemented in numerous countries in the form of education. Reparations or assistance programs (proposed or implemented) in Peru, Sierra Leone, TimorLeste, and Colombia have included education as an individual or material benefit or as part of a social service package. These benefits can include scholarships, reduced school fees, tuition and accommodation assistance, stipends, accelerated or fast-track programs, psychosocial support, and childcare facilities for students with their own children. Such benefits can facilitate access to education at the primary, secondary, tertiary, vocational/technical, and adult levels. ${ }^{20}$ In some cases, such as Argentina, Brazil, Chile, Nepal, and Peru, the children of victims of violations have also received educational benefits. ${ }^{21}$ Collective reparations can include the (re)building of school infrastructure, the allocation of resources to conflict-affected areas or the reduction of fees and hidden costs in those areas, and the provision of bilingual and intercultural education. In South

Assembly Res. 2200A (XXI), December 16, 1966. As with other socioeconomic rights, however, it should be read in conjunction with Art. 2 of the covenant, which recognizes the progressive attainment for the full realization of rights of this sort. See also Art. 24 of the Convention on the Rights of the Child, General Assembly Resolution 44/25, November 20, 1989.

18 Cristián Correa, "Education for Overcoming Massive Human Rights Violations," in Transitional Justice and Education.

19 Paulson, "(Re)Creating Education in Postconflict Contexts," 20.

20 Dyan Mazurana and Khristopher Carlson, "Reparations as a Means for Recognizing and Addressing Crimes and Grave Rights Violations against Girls and Boys during Situations of Armed Conflict and under Authoritarian and Dictatorial Regimes," in The Gender of Reparations: Unsettling Sexual Hierarchies while Redressing Human Rights Violations, edited by Ruth Rubio-Marín (New York: Cambridge University Press, 2009).

21 Lorena Escalona González, "Education as a Form of Reparation in Chile," in Transitional Justice and Education. 
Africa, the truth commission recommended community rehabilitation via the rebuilding of schools, and in Peru some communities have used collective compensation to do likewise. ${ }^{22}$

\section{School Environment, Culture, and Governance}

On account of either the direct legacy of the previous regime in the educational system, or violence that infiltrated schools during the conflict, the reform of school culture and governance presents a critical dimension of education reform in a transitional context. The legacies of authoritarian or violent educational cultures among the interpersonal relationships within educational institutions, families, communities, and the students themselves can include despotism of school authorities, corporal punishment and other forms of teacher or student violence, discrimination, and sexual harassment. ${ }^{23}$ Peru's truth commission, for example, in acknowledging this aspect of the educational culture after conflict, considered that both eliminating violence and reforming authoritarian pedagogy were important in fostering a culture of human rights in schools. ${ }^{24}$

Constructive strategies to promote reflection on good governance and nonviolence within a school community include classroom discussions on teaching/ learning methods and peer relations, or extracurricular activities, such as student government or conflict-resolution committees. ${ }^{25}$ Rather than being left to the teachers, however, it should involve administrators, parents, students, and, in some instances, the community as a whole. Importantly, in post-conflict contexts, establishing safe schools - and, more broadly, safe spaces in which students and teachers can speak about the violent past - should include mental health considerations. In this respect, before teaching the violent and conflictive past in the classroom, it may be necessary to put in place measures to promote wellbeing and build resilience among both students and educators. It may be also be necessary to deal with trauma, and therefore to provide psychosocial support. Further, help may be required in order to identify additional or special needs of children with a view to specialist referral and community case management. ${ }^{26}$

22 ICTJ/APRODEH, ¿Cuánto se ha reparado en nuestras comunidades? Avances, percepciones y recomendaciones sobre reparaciones colectivas en Perú 2007-2011 (Lima: ICTJ and APRODEH, 2011), 41-42.

23 Ana María Rodino, "Teaching about the Recent Past and Citizenship Education during Democratic Transitions," in Transitional Justice and Education.

24 Comisión de la Verdad y la Reconciliación del Perú, "Recomendaciones," 136.

25 Rodino, "Teaching about the Recent Past"; see also Fumiyo Kagawa and David Selby, ChildFriendly Schooling for Peacebuilding (New York: UNICEF, 2014).

26 For more on psychosocial considerations in transitional justice contexts, see An Michels, "Psychosocial Support for Children: Protecting the Rights of Child Victims and Witnesses in 


\section{Curriculum Reform}

Revising the content of curricula provides a new government with the opportunity to convey a narrative about the country's recent past to younger generations. Such a narrative will play a fundamental role in influencing national identity and the building of state legitimacy. It also can be crafted in a way that contributes to critically reflecting on the legacies of the past while promoting a more democratic notion of citizenship. With this goal in mind, numerous truth commissions have included among their final recommendations the reform of the school curriculum to teach the recent past and inculcate a culture of human rights. In post-World War II Germany, "a whole textbook section under the Education Branch of the Control Commission undertook the vast task of revising school textbooks." ${ }^{27}$ In South Africa, the current history curriculum examines the country's violent past as well as the transition process as part of a broader political commitment to dealing with the legacies of apartheid. ${ }^{28}$

When teaching the past, the focus should not only be on those whose rights were violated, but also on explanations as to why and how the conflict emerged and how different groups within a society can be led to engage in violence. This supports the notion that there is more to past conflict than the simplistic victimperpetrator binary. It is only by acknowledging the complexity of the past that a society can create a space in which the offspring of both victims and perpetrators can discuss these issues safely. ${ }^{29}$ To the extent that schools are stable and safe environments, the classroom can serve as a unique space in which children and young people can reflect on and discuss the past critically and without fear, helping them to better elaborate on and contextualize their own beliefs and challenge any personal assumptions.

Transitional Justice Processes" (Florence: Innocenti Research Centre/UNICEF, 2010), at www.unicef-irc.org/publications/pdf/iwp_2010_14.pdf, accessed 5 February 2018.

27 Nina Arnhold et al., eds., Education for Reconstruction: The Regeneration of Educational Capacity Following National Upheaval (Oxford: Oxford University Press, 1998), 23.

28 See National Curriculum Statement Grades 10-12 (General): Learning Program Guidelines, History (Pretoria: Department of Education of South Africa, 2008), quoted in Dylan Wray, "Facing the Past - Transforming Our Future: A Professional Development Program for History Teachers in South Africa," in Transitional Justice and Education. See also Najwa Belkiz's case study on Morocco in this volume.

29 For a more complete discussion on this topic, see Ervin Staub, ed., The Psychology of Good and Evil: Why Children, Adults and Groups Help and Harm Others (New York: Cambridge University Press, 2002). 
Pedagogy and Teaching Methods

Pedagogical approaches can improve children's capacity for critical thinking and engaged citizenship in a manner relevant to their immediate lives. There is often a need to move away from teacher-centered and authoritarian methods and toward those favoring more egalitarian and participatory approaches. The latter encourage critical, independent, and creative thinking on the part of the students, appeal to their emotional imagination and capacity to feel empathy, and encourage their disposition for active citizenship. ${ }^{30}$ Pedagogical practices should aim to strengthen the culture of democracy among students, reinforcing the idea that disagreement and deliberation are part of societal interaction, while contributing to the development of students' creativity, attitudes, and skills. Students are then more likely to learn to listen to others and solve conflicts in a peaceful manner. Multiple places also exist outside of the classroom where children and young people can learn about the past while actively participating in educational activities. Memory museums and sites of conscience offer opportunities for students to become engaged with issues of memory and justice. The chance to attend a truth commission public hearing or a trial session may also provide powerful learning opportunities. When dealing with issues that may trigger emotional responses among students, however, safe spaces for discussion may be required and, if necessary, conflict-management tools such as the introduction of mutual-respect rules, or the preparation of topics to be discussed in the classroom by different groups of students.

\section{Teaching Tools}

A wide range of teaching tools can support educators and help students learn about the recent contested past. These can include more traditional resources, both printed materials (such as textbooks, study guides, and lesson plans) and audiovisual media (video clips, documentaries, and audio segments), but also materials that serve to directly portray memory, such as sites of remembrance, artifacts, celebrations, testimonies, and journals. ${ }^{31}$ Under normal circumstances, textbooks are the first and most common resource used in the classroom; however, the production of textbooks is a lengthy and costly process that requires transparency and a broad societal consensus. Initial efforts can instead focus on purging existing textbooks of distorted, manipulated, and hateful

30 An interesting reflection on some pedagogical considerations when teaching the difficult past can be found in Sara Clarke-Habibi's chapter in this volume.

31 Rodino, "Teaching about the Recent Past." 
messages and on using complementary materials that are less controversial. ${ }^{32} \mathrm{~A}$ truth commission or a criminal trial provides a useful opportunity to design complementary teaching tools. In 2004, for instance, the Truth and Reconciliation Commission of Sierra Leone partnered with UNICEF to produce its final report as well as a video report for children and secondary schools. ${ }^{33}$

Audiovisual media have also been useful means to promote learning and facilitate discussion among children and young people. ${ }^{34}$ As part of its educational outreach program, the Liberation War Museum in Bangladesh invites students to view a documentary film on the history of the liberation struggle, visit the gallery, and participate in a quiz competition. The Special Court for Sierra Leone and the International Criminal Court have also used film and documentary screenings followed by question-and-answer sessions when visiting schools as part of their children and youth outreach programs on teaching about the legacies of the past. Oral history projects and testimonies are especially powerful educational tools because they tell personal stories of how people lived through and experienced a conflict. In Lebanon, a project called "Badna Naaref" was conducted between 2010 and 2012 as both an oral history and truth-seeking exercise, involving students under the supervision of their teachers. ${ }^{35}$ Testimonies and intergenerational dialogue should be handled with care, however, as personal accounts are experiential and require an adequate contextualization.

\section{Teacher Capacity and Training}

Teachers' ability, confidence, and willingness to teach the past are critical to the effectiveness of all education reforms. Teachers' roles are not just as purveyors of a curriculum, but as influential actors who can promote (as well as undermine) transitional justice goals. ${ }^{36}$ To prepare teachers to teach the injustices of the past effectively, "Teacher development programs (both pre and in service) need to provide the space and support for teachers to confront their own identities, legacies and biases and to begin the process of self-reflection." ${ }^{37}$ Such programs

32 Elizabeth A. Cole, "Transitional Justice and the Reform of History Education," International Journal of Transitional Justice 1 (2007): 135.

33 On this process, see Denise Bentrovato's contribution in this volume, and, for the Colombian context, the chapter by María Andrea Rocha.

34 Rodino, "Teaching about the Recent Past."

35 Lynn Maalouf and Christalla Yakinthou, "Grappling with Lebanon's Enduring Violence: Badna Naaref, an Intergenerational Oral History Project," in Transitional Justice and Education.

36 Davies, "The Power of a Transitional Justice Approach to Education."

37 Weldon, "Conflict, Identity and Intergenerational Transmission of Memory," 4. See also Nadia Siddiqui's chapter in this volume. 
should also provide teachers with the necessary knowledge and ethical and technical means, and empower them to use democratic methods in the classroom.

Changing how teachers teach, however, is difficult, especially when there are limited resources available and when teachers tend to be inadequately prepared. ${ }^{38}$ While there is plenty of room for civil society organizations to develop teacher-training programs of this sort, ultimately this should be an official endeavor at the state level to ensure that it is designed and implemented effectively and systematically. In this respect, paying attention to teacher training also implies reforming the teaching-learning institutions and the methodologies they employ. Ideally, support to teachers charged with teaching the past should be ongoing. ${ }^{39}$ A less costly alternative may be to create networks of teachers so that they can support each other's work in the classroom.

\section{The Role of Actors in Enacting and Resisting Change}

Education systems are very difficult to change, especially when reform emphasizes the need to address past injustices. It is a process that requires significant political and financial investment and a great deal of time. As Lynn Davies argues, a political lens is part of the distinctiveness and power of this kind of approach to reform: education reform that involves addressing past injustices can both catalyze change and also signal that a new government is committed to democracy and peace. But because it introduces issues of accountability and redress to the governance of a major societal institution, it is also likely to be contested at various levels. ${ }^{40}$ As a result, truth commission recommendations for education reform often go unheeded, reparations programs struggle to be implemented, and comprehensive education reforms are rarely integrated into a wider transitional justice framework. ${ }^{41}$

A range of actors have stakes in addressing the past through education, and each can be an agent of and/or an obstacle to change. Consultation and engagement with relevant stakeholders and partners is therefore fundamental for any sustainable educational reform process. Education reform that is sensitive to transitional justice listens to the voices of educational authorities, school ad-

38 Laura J. Quaynor, "Citizenship Education in Post-Conflict Contexts: A Review of the Literature," Education, Citizenship and Social Justice 7, no. 1 (2012): 47.

39 Elizabeth A. Cole and Judy Barsalou, "Unite or Divide? The Challenges of Teaching History in Societies Emerging from Violent Conflict," Special Report 163 (Washington, D.C.: USIP, 2006), 11.

40 Davies, "The Power of a Transitional Justice Approach to Education."

41 Murphy, "Educational Reform through a Transitional Justice Lens." 
ministrators, curriculum experts, teachers, students, parents, and civil society organizations, each of which will have a different perspective on how the legacies of the past should be addressed. This approach also expands the range of institutional and individual actors engaged in transitional justice, allowing more parties to become involved and engaged with a framework from which they are often excluded. ${ }^{42}$

\section{Transitional Justice Measures}

Transitional justice measures can be designed with a view to establishing links with and catalyzing change within the field of education. Truth commissions, for example, often make recommendations related to education, both about education reform and reparations programs that include the provision of educational assistance to victims. In South Africa, Peru, Morocco, Sierra Leone, and Timor-Leste, commissions identified structural injustices and education-related needs that were addressed by subsequent efforts to improve the provision of education to populations that had suffered marginalization and discrimination. ${ }^{43}$ Truth commissions have arguably played a role in prioritizing education reform in South Africa, Peru, and Morocco, but less so in Sierra Leone and Timor-Leste, where the implementation of recommendations has remained limited. ${ }^{44}$ In some cases, truth commissions and criminal courts and tribunals have also used education as part of their outreach strategies. ${ }^{45}$ Educational tools have been fundamental in this respect when seeking to engage children and young people in a transitional justice process, but also as a means of building a legacy and ensuring the sustainability of justice-related initiatives. ${ }^{46}$

The absence of a legitimate transitional justice framework, on the other hand, can undermine efforts to repair society and achieve reconciliation through education. In Bosnia-Herzegovina and Northern Ireland, for instance, no comprehensive transitional justice framework exists, and education reforms have been only partially implemented, remaining mostly technical and neutral with regard to dealing with the past. ${ }^{47}$ In cases when the absence of a legitimate

42 Cole, "Transitional Justice and the Reform of History Education," 120.

43 Cristián Correa, "Education for Overcoming Massive Human Rights Violations." See more generally Parmar et al., Children and Transitional Justice.

44 Correa, "Education for Overcoming Massive Human Rights Violations."

45 See also Clara Ramírez-Barat, Engaging Children and Youth in Transitional Justice Processes: Guidance for Outreach Programs (New York: ICTJ, 2012); and UNICEF/ICTJ, Children and Truth Commissions (Florence: UNICEF, 2010), 21-28.

46 Nerma Jelacic, "Building a Legacy: The Youth Outreach Program at the ICTY," in Transitional Justice and Education.

47 Murphy, "Educational Reform through a Transitional Justice Lens." 
national transitional justice framework suggests that a society has not taken broader steps to address the divisions of the past, or when a transitional justice policy has been officially endorsed but is overly politicized or unsupported, however, it may still be possible to address the past in educational settings at more local, informal levels.

\section{Civil Society}

Implementation and long-term sustainability of education reform will depend on the support and participation of civil society. For the implementation of truth commission recommendations and reparations programs that provide educational assistance, for example, the strength of civil society and victims' movements is crucial. ${ }^{48}$ Furthermore, education strategies should not be limited to the formal school system, given the number of children and young people who may not be enrolled in school in transitional contexts and the important role played by the community as part of the children's immediate and natural support and protection systems. Education strategies should therefore collaborate with informal initiatives and community-level structures. Non-formal and informal education forums can serve as important vehicles to trigger, reinforce, and sustain changes in the formal educational system. These may be especially relevant when institutional structures of the state remain weak after conflict.

Transitional justice outreach initiatives aimed at the education system can prompt civil society efforts to address the past through education after those justice measures have ceased to function. The ICTY youth outreach program aimed to "[transfer] the ownership of the project to local partners in order to ensure its sustainability," 49 by training high-school teachers to deliver the standardized presentations it had developed, creating and training a network of local groups to do so when teachers were unwilling or unable, and producing teaching tools and materials for those teachers and activists. Civil-society actors can also initiate and catalyze efforts to address the past, particularly when transitional justice measures and the formal school system cannot. ${ }^{50}$ In Côte d'Ivoire, ICTJ worked with local students and youth human rights organizations at the community level to create a group of young people engaged in transitional justice. ${ }^{51}$ There are many examples of civil society groups that have developed

48 Correa, "Education for Overcoming Massive Human Rights Violations."

49 Jelacic, "Building a Legacy," 268.

50 Rodino, "Teaching about the Recent Past"; Maalouf and Yakinthou, "Grappling with Lebanon's Enduring Violence."

51 Virginie Ladisch and Joanna Rice, "Addressing the Recent Past in Schools: Reflections from Côte d'Ivoire," in Transitional Justice and Education. 
educational materials and activities later to be incorporated into the formal curricula for history education in places as varied as Cambodia, Canada, Northern Ireland, and South Africa. ${ }^{52}$

\section{School Communities}

School communities can be involved in addressing the past in different ways. For example, teacher and student participation may be especially relevant when designing and testing new materials. While ensuring consultation with, and participation of, school communities takes time and resources, in the long term, taking into account the views of the direct recipients of the policies and programs contributes to maximizing their relevance, legitimacy, and sustainability. Within school communities, however, some students, teachers, and administrators may present obstacles. First, prevailing agendas and cultures or newly opened schisms between group identities may undermine a transitional justice approach to education reform. Multiple agendas for curriculum reform, for example, may conflict with each other, such as those emphasizing human rights and democracy and those with a more technical focus on economic empowerment. ${ }^{53}$ Discrimination between identity groups can also create difficult environments for students who receive assistance through reparations programs, potentially increasing their dropout rates. ${ }^{54}$

Second, teachers may not have the necessary skills or confidence to teach the past, may be reluctant to admit their own bias or their role in past injustices, may be frustrated at being made responsible for reconciliation, or may resist out of a real fear of physical threats from those who oppose such efforts. In the former Yugoslavia, for example, "Many teachers have expressed concern about allowing such discussions in their classrooms, citing security fears, reactions of parents, but most often their own beliefs about the war." 55 Finally, school administrators may present obstacles to a transitional justice approach. In Argentina and Chile, attempts to deal with the past in schools have been met with opposition, inconformity, and conflict. The school system itself - which reflects social and

52 See, for example, the chapters in this volume by Stefana Fratila and Jasmina Brankovic.

53 André Keet and Felisa Tibbitts, "Curriculum Reform in Transitional Justice Environments: The South African Human Rights Commission, Human Rights Education and the Schooling Sector," Internal Study, ICTJ Research Project: Transitional Justice, Education and Peacebuilding, 2015, 28.

54 Rosa Lía Chauca, "Reparaciones y Educación en Perú," Internal Study, ICTJ Research Project: Transitional Justice, Education and Peacebuilding, 2015.

55 Jelacic, "Building a Legacy," 272. 
community dynamics - is often reluctant to deal with conflictive or controversial issues. $^{56}$

\section{Government}

While educational efforts to address the past often originate with transitional justice measures or civil society actors, the government's involvement is necessary in order to effect change throughout the education system as a whole. ${ }^{57}$ It is the "horizontal and vertical structures" of the education system that make it such a strong partner for transitional justice processes. ${ }^{58}$ In Sierra Leone, although the truth commission did reach out to students and teachers, "the education system was not a partner from the beginning in the creation, dissemination, and teaching of the child-friendly report." 59 The Peruvian truth commission, in contrast, had an agreement with the Ministry of Education, a staff member who worked with the ministry, teacher trainings, and educational materials for students and teachers. ${ }^{60}$ Similarly, the ICTY's youth outreach project specifically sought to engage local authorities in a dialogue in order to ensure government support. And for the team running "Badna Naaref" in Lebanon, visiting schools, explaining the project, and waiting for responses constituted "one of the most crucial and sensitive phases" of the work. ${ }^{61}$

Nevertheless, national and local governments may withhold their approval or support. In South Africa, for example, the department of education has not officially supported at the national level teacher training or guidance programs for educators regarding how their own experiences of the past can affect whether and how they teach apartheid to students. ${ }^{62}$ In the countries of the former Yugoslavia, the majority of governments "have not been favorably inclined toward the ICTY and have been skeptical about extending their support" to the court's youth outreach project aimed at schools. Negotiations with local authorities

56 Sandra Raggio, “'Historia o memoria en las aulas?” in Efemérides en la memoria. 24 de marzo, 2 de abril, 16 de septiembre. Propuestas para trabajar en el aula, edited by Sandra Raggio and Samanta Salvatori, eds. (Rosario: Homo Sapiens Ediciones Argentina, 2012), 22, quoted in Rodino, "Teaching about the Recent Past." Maalouf and Yakinthou, "Grappling with Lebanon's Enduring Violence."

57 Rodino, "Teaching about the Recent Past."

58 Elizabeth A. Cole, "No Legacy for Transitional Justice Efforts Without Education: Education as an Outreach Partner for Transitional Justice," ICTJ Studies in Education and Transitional Justice (New York: ICTJ, 2017), 10.

59 Ibid.

60 Paulson, "(Re)Creating Education in Postconflict Contexts," 17.

61 Maalouf and Yakinthou, "Grappling with Lebanon's Enduring Violence," 399.

62 Wray, "Facing the Past - Transforming Our Future." 
could be lengthy, bureaucratic, difficult, and not always successful. ${ }^{63}$ Government reluctance can also manifest itself in terms of how such educational programs are defined. For transitional justice efforts to have their intended effect, for instance, policymakers need to distinguish between reparations and general reconstruction, development, and social policies. They may often resist doing so, however. While Nepal and Colombia have set up or planned programs providing educational assistance to victims, they do not label them "reparations" because of the acknowledgement of wrongdoing on the part of the state that this would imply. ${ }^{64}$

\section{Capacity and Resource Constraints}

Challenges to the implementation of education reform informed by transitional justice arise in the form of constraints, amongst other restrictions, usually in terms of capacities and resources. Perhaps most importantly, damaged and weak education systems in post-conflict countries can significantly hinder progress. For truth commissions, for example, the implementation of recommendations for reform may be undermined by an education system without sufficient institutional capacity. Similarly, reparations in the form of educational assistance may succeed in increasing victims' access to schools, but the program's impact may be undermined by the quality of education provided and the psychosocial difficulties faced by beneficiaries. ${ }^{65}$ In Sierra Leone, challenges such as a shortage of teachers, the number of destroyed schools, the number of children out of school, and other reconstruction needs made it difficult for justice measures to connect with the education system and served as a hindrance to follow-up and sustainability. ${ }^{66}$ Civil-society actors also suffer from resource and capacity constraints. In Lebanon, for instance, challenges included a significant underresourcing of the organizations involved, internal administrative burdens, and a lack of resources and capacity to sustain the project or expand it geographically. ${ }^{67}$ At the broadest level, the wider structural context can present challenges in terms of differences in power and economic resources that remain after conflict, with school choice and resources unequally distributed throughout the country, as in South Africa and Peru. ${ }^{68}$

63 Jelacic, "Building a Legacy," 270.

64 Correa, "Education for Overcoming Massive Human Rights Violations."

65 Chauca, "Reparaciones y Educación en Perú."

66 Zoe Dugal, "Outreach to Children in the Transitional Justice Process of Sierra Leone," in Transitional Justice and Education.

67 Maalouf and Yakinthou, "Grappling with Lebanon's Enduring Violence."

68 Correa, "Education for Overcoming Massive Human Rights Violations." 
Opposition from actors often relates in part to the use of a discourse that involves an acknowledgment of wrongdoing. At the same time, however, linking justice and education can also lead to the prioritization of certain communities or groups of people over others in the allocation of resources and provision of services, which can provoke further tensions. ${ }^{69}$ Collective reparations, for example, can create disagreement within communities regarding whether resources should be allocated to schools or other needs. They can also create tensions by singling out groups of victims or establishing what is perceived as a hierarchy of victims. Interventions to improve education targeted at groups and regions badly affected by conflict can be interpreted as an attempt to advantage one group or region over another, creating problems of stigmatization. ${ }^{70}$

\section{Opportunities and Expectations}

A transitional justice environment is often a context of significant policy change, with opportunities for actors to engage in "intensified competition" over ideas for education and other public services and goods. ${ }^{71}$ In addition to understanding where support for and reluctance to addressing the past through education are likely to originate and which constraints are likely to be faced, a strategic approach to enacting change should involve identifying opportunities for measures and reform but also remaining realistic about the kind and degree of change that is feasible. It will be necessary to remember that changes in the formal education system are necessarily part of a mid- or long-term process.

Efforts to link transitional justice and education should manage expectations regarding their impact. An education system is a large, complex body that is difficult to change, which means that time, scale, and feasibility are factors that must be considered. As Ana María Rodino argues, old structures must be removed before putting new ones in place; a review of the educational norms and system may be necessary to remove harmful authoritarian practices and the denial of rights before positive reforms can be gradually enacted. ${ }^{72}$ At an early stage in the process, at least, it may be important "not to expect too much, and be content with small, measurable changes," and to be aware of the fact that the

69 Roger Duthie and Clara Ramírez-Barat, "Education as Rehabilitation for Human Rights Violations," International Human Rights Law Review 5, no. 2 (2016): 241-273.

70 ICTJ, The Rabat Report (New York: ICTJ, 2009), 52-3, 59; Alan Smith, Children, Education and Reconciliation, Innocenti Working Paper (Florence: UNICEF Innocenti Research Centre, 2010), 18; UNESCO, Education for All Global Monitoring Report 2011: The Hidden Crisis: Armed Conflict and Education (Paris: UNESCO, 2010), 230, 240.

71 Keet and Tibbitts, "Curriculum Reform in Transitional Justice Environments," 2.

72 Rodino, "Teaching about the Recent Past." 
responsibility for perceived failure or partial failure may fall to students or teachers. $^{73}$

Entry points may nevertheless be identified through which change may be initiated on a small scale and then leveraged for greater reform in the future. Given the various forms of opposition and constraints, this may be difficult, but usually some kind of opportunity will present itself. As Elizabeth Cole suggests, even when the political conditions for a formal transitional justice process are absent, only rarely will there be no political space for educational activities. Different levels of education, for example, may offer different opportunities: if activities are too sensitive for students in basic education, it may be possible to implement them within universities, where students are often granted more political space. ${ }^{74}$

Timing will also be an important factor. Under ideal circumstances, education reform should be developed in contexts where there is no ongoing conflict and at least some institutional and social willingness to discuss the past. It is then that education reform and transitional justice policies can maximize their mutually reinforcing impact. "Educational reforms are not one-off and unidirectional," writes Rodino, but "should move in different directions simultaneously in order to affect several areas or components of the educational system." This does not mean "that all the changes should (or can) occur together or at the same time after the end of a conflict, because each education system is conditioned by the particular contexts in which it exists." Depending on context, goals may be achieved only gradually. ${ }^{75}$

Finally, it is important to have clearly defined, achievable goals, such as helping victims to overcome the obstacles to education that are the result of previous human rights abuses. There is a danger in promising too much to poor and vulnerable members of society. ${ }^{76}$ Responding to deeply historical marginalization requires a long-term commitment of resources and political capital beyond the capacities of most transitional justice efforts on their own. This is why addressing the past through education needs to be complemented with broader reform, reconstruction, and responses to problems such as inequality and segregation. While progress can be made by linking transitional justice and education, lasting change requires intergenerational engagement and the commitment of the affected communities.

73 Davies, "The Power of a Transitional Justice Approach to Education."

74 Cole, "No Legacy for Transitional Justice Efforts Without Education"; Maalouf and Yakinthou, "Grappling with Lebanon's Enduring Violence."

75 Rodino, "Teaching about the Recent Past," 34.

76 Correa, "Education for Overcoming Massive Human Rights Violations." 


\section{About this volume}

This volume is composed of two parts. In the first, on Designing and Implementing Educational Media and Materials for Transitional Justice, the authors examine the role, usage, and design of educational media and materials in transitional justice programs, including projects in Canada, Colombia, Morocco, Sierra Leone, and Rwanda. Chapter one, by María Andrea Rocha, begins by introducing the work of the National Center for Historical Memory (Centro Nacional de Memoria Histórica, $\mathrm{CNMH}$ ), which encourages teachers in Colombia to begin class discussions on the conflict. After contextualizing Colombia's efforts with similar experiences in Chile, Guatemala and Spain, Rocha identifies several obstacles, including the quality of textbooks, the occasionally politicized attitudes of teachers, and the apathy of students. The paper uses the example of the CNMH's recently developed "Teacher's Toolbox" to show how teachers' research and critical thinking skills have been developed, and how a sense of socio-historical agency and empathy has been fostered among students when dealing with the violent past in the classroom. The CNMH's work thus illustrates the use of a transitional justice framework by explicitly but carefully addressing the society's recent traumas and human rights abuses for the sake of future stability and a strong democratic culture.

In Chapter Two, Denise Bentrovato addresses the efficacy of outreach efforts by various transitional justice measures in Rwanda and Sierra Leone. She analyzes educational materials and graphic novels designed for children and young people for use in Rwanda and Sierra Leone, with regard to the depiction and the historical contextualization of the wars in each case. Bentrovato finds that such documents would be scrutinized as to their compliance with the government's official discourse on the past conflict, and that grim graphic or cartoon depictions of the war could distract from learning about the causes of the conflict. She uses the results of her fieldwork in both countries to show that such documents were in fact rarely used, and that teachers could be reluctant to address such sensitive issues. Her findings reveal that both the content and the provenance of the documents are limiting their grass-roots impact, and as a result she suggests that with adequate teacher training the documents could be treated as cultural artefacts worthy of critical analysis within the classroom.

In the third chapter, Najwa Belkziz examines the results and recommendations of Morocco's Truth Commission of 2004, the Instance Equité et Réconciliation. She compares the relative successes of memory studies and human rights education in the country following the work of the commission, and points to missed opportunities for memory recovery through a new master's program on history, as well as the opening and use of the Truth Commission's archives for research purposes. The analysis discloses that Human Rights Edu- 
cation (HRE) must be paired with effective memory studies if education is to adequately address the transitional nature of Moroccan society. Precisely because of the failure of the process to adequately deal with the past, efforts made in the field of education and memorialization have resulted in the creation of an official narrative promoting a forward-looking justice approach based on a break with the past, social cohesion, and reconciliation. This calls for curriculum designers to open up the discussion of the recent past, and to the National Council for Human Rights to allow wider access to their archives.

In the concluding chapter of this section, Stefana Fratila addresses the difficulties of applying transitional justice methods to a country like Canada which, she points out, still suffers from colonial conflict. Fratila analyzes the work of the Truth and Reconciliation Commission, which was completed in 2015, critiquing how it treated colonialism as a historical rather than present experience, and how it emphasized the importance of Indigenous healing without examining the relationships between current settlers and Indigenous people. She finds that reconciliation in Canada is limited by two factors: an unwillingness to recognize Indigenous people's rights to land, and the persistence of colonial and capitalist structures which compromise any depiction of Canada as a transitional society. Fratila endorses alternative methods of education which have contributed towards memorializing Indigenous victims of a colonizing education system: Indigenizing formal education and sustaining Indigenous knowledge. Her findings point toward both formal and informal education settings as areas of focus for those using education to truly contribute to reconciliation in Canada.

Part II of the volume, on Education in Transitional Justice Contexts: Actors and Practices, begins with a chapter on memorialization in Rwanda by Daniel Haumschild. Haumschild problematizes the functions of commemoration and public memory by educational institutions in postwar societies, taking the methodology of the Murambi Genocide Memorial Center in Rwanda as a case study. Following a theoretically rooted reflection, Haumschild explores how a problematic methodology of "intolerable realism" can interfere with the memorial's intended "never again" message by rendering the public incapable of responding in a critical, rational, or reflective manner. The chapter argues that this type of exposure to violent history and the public's inability to speak out against the testimony of corpses leads to a greater deference to the authorities who arrange such exposure. This has ominous implications because, contrary to appearances, controlling citizens through their vulnerability when encountering death follows a similar set of logics to genocide itself.

Chapter Six, by Sara Clarke-Habibi, explores the relationship between what she identifies as "transitional justice education" and other educational approaches, examining possible precedents in search of insights into its design and implementation. Clarke-Habibi explores the pedagogies of peace education, 
human rights education, and conflict-sensitive education, concluding that such approaches do not adequately address the specific histories of those in the classroom in order to fulfill this objective. The analysis identifies similarities between Holocaust education and transitional justice education and argues for the implementation of pedagogical, political, and ethical aspects together with considerations and lessons learned in the classroom from Holocaust education for both educators and decision-makers. She also lays down a series of recommendations, advocating use of the vast literature on Holocaust education to guide the implementation of transitional justice lessons.

Jasmina Brankovic's chapter on human rights education in post-apartheid South Africa compares the approaches of the Khulumani Support Group and formal educational institutions in incorporating human rights education into post-apartheid education reform. Brankovic notes how the introduction of Human Rights Education in South Africa after the end of apartheid masked the continuity of past injustices and came into conflict with the neoliberal culture of competitiveness and economic productivity also proposed in the newly democratic period. Brankovic argues that the strategies of civil-society victims' groups such as Khulumani are more responsive to the educational needs of a transitional society. Importantly, she outlines Khulumani's emphasis on intergenerational exchange, approach to socioeconomic exclusion, willingness to question the state order, and recognition of victims as present, active citizens. Reflecting upon how Khulumani demonstrates more courage than the South African government, she questions whether it is the role of those from within or without state institutions to promote transformative agendas.

Nadia Siddiqui's chapter, on the other hand, addresses the difficult and sometimes traumatic experiences of educators teaching transitional justice, examining the potential of the performing arts and of storytelling for their work and personal development. Exploring arts-based forms and methodologies for storytelling and performative processes, she presents research on formal and informal education settings in the countries of Lebanon, Afghanistan, and Iraq. According to Siddiqui, "Participatory theatre and storytelling exercises and practices can offer opportunities for participants to step outside their routines and as a result find new symbols, meaning, and connection regarding themselves and in relation to others."

Lastly, Ties Schelfhout and Ruben Bücking examine the work carried out by the Institute for Historical Justice and Reconciliation (IHJR), with a particular focus on activities seeking to bridge the gap between research and educational practice. The authors focus on the institute's original shared-narrative approach as a transitional justice educational tool, designed to change perspectives among scholars, educators, and youth in divided societies through historical research and education. Schelfhout and Bücking outline the efforts and the challenges 
involved in moving beyond the constraints of a research organization to the stage of a "hybrid" institution. Such an organization seeks to connect academia and educators and promote historical reconciliation by disseminating its research to relevant stakeholders, eventually reaching and engaging young people. As they describe the various steps of the Institute's theory of change, they highlight the special role of historians whom the Institute has encouraged to take on the role of active advocates in the process of reconciliation, which has at times clashed with their professional ethos.

All in all, these chapters provide a broad overview of a variety of contexts from all over the world, reflecting from many different perspectives on how education can contribute to transitional justice. With a particular view to practical issues and the challenges in linking transitional justice and education in the aftermath of massive human rights violations, the volume offers insights and ideas on how to develop educational materials, activities, and programs in transitional justice settings. Some of the issues considered include distinguishing between political, social and practical challenges, identifying different strategies for overcoming them, and looking into key points of entry in education systems for content and strategies for transitional justice. We hope this volume will provide a solid contribution to the broader reflection on the importance of public culture in support of human rights and democratic values in transitional justice contexts. Ultimately, however, this collection of essays seeks to explore how education can effectively help to build societies that are better equipped and more resilient in making effective the promise of never again.

\section{Bibliography}

Arnhold, Nina et al., eds. Education for Reconstruction: The Regeneration of Educational Capacity Following National Upheaval, Oxford: Oxford University Press, 1998.

Bellino, Michelle J., Julia Paulson, and Elizabeth Anderson Worden. "Working Through Difficult Pasts: Democracy and Transitional Justice in Education." Comparative Education 53 (2017): 313-332.

Bentrovato, Denise. "Accounting for Genocide: Transitional Justice, Mass (Re)education and the Pedagogy of Truth in Present-day Rwanda." Comparative Education 53 (2017): 396-410.

Buckland, Peter. Reshaping the Future: Education and Post-Conflict Reconstruction. Washington, D.C.: World Bank, 2004.

Bush, Kenneth D. and Diana Saltarelli. The Two Faces of Education in Ethnic Conflict: Towards a Peacebuilding Education for Children. Florence: UNICEF Innocenti Research Centre, 2002.

Chauca, Rosa Lía. "Reparaciones y Educación en Perú.” Internal Study. ICTJ Research Project: Transitional Justice, Education and Peacebuilding, 2015. 
Cole, Elizabeth A. "No Legacy for Transitional Justice Efforts Without Education: Education as an Outreach Partner for Transitional Justice." ICTJ Studies in Education and Transitional Justice. New York: ICTJ, 2017.

Cole, Elizabeth A. "Transitional Justice and the Reform of History Education." International Journal of Transitional Justice 1 (2007).

Cole, Elizabeth A., ed. Teaching the Violent Past: History Education and Reconciliation. New York: Roman \& Littlefield, 2007.

Cole, Elizabeth A. and Judy Barsalou. "Unite or Divide? The Challenges of Teaching History in Societies Emerging from Violent Conflict." Special Report 163. United States Institute of Peace (USIP). Washington, D.C.: USIP, 2006.

Comisión de la Verdad y la Reconciliación del Perú. "Recomendaciones.” In Informe Final. Vol. IX. Lima: Comisión de la Verdad y la Reconciliación del Perú, 2003.

Correa, Cristián. "Education for Overcoming Massive Human Rights Violations." In Transitional Justice and Education: Learning Peace, edited by Clara Ramírez-Barat and Roger Duthie. New York: SSRC, 2017.

Davies, Lynn. Education and Conflict: Complexity and Chaos. London: Routledge, 2003.

Davies, Lynn. "The Power of a Transitional Justice Approach to Education: Post-Conflict Education Reconstruction and Transitional Justice." ICTJ Studies on Education and Transitional Justice. New York: ICTJ, 2017.

De Greiff, Pablo. “Theorizing Transitional Justice.” Nomos 51 (2012): 31-77.

Dugal, Zoe. "Outreach to Children in the Transitional Justice Process of Sierra Leone." In Transitional Justice and Education: Learning Peace, edited by Clara Ramírez-Barat and Roger Duthie. New York: SSRC, 2017.

Duthie, Roger and Clara Ramírez-Barat. "Education as Rehabilitation for Human Rights Violations." International Human Rights Law Review 5, no. 2 (2016): 241-273.

Escalona González, Lorena. "Education as a Form of Reparation in Chile.” In Transitional Justice and Education: Learning Peace, edited by Clara Ramírez-Barat and Roger Duthie. New York: SSRC, 2017.

ICTJ. The Rabat Report. New York: ICTJ, 2009.

ICTJ/APRODEH, ¿Cuánto se ha reparado en nuestras comunidades? Avances, percepciones $y$ recomendaciones sobre reparaciones colectivas en Perú 2007-2011. Lima: ICTJ and APRODEH, 2011.

Jelacic, Nerma. "Building a Legacy: The Youth Outreach Program at the ICTY." In Transitional Justice and Education: Learning Peace, edited by Clara Ramírez-Barat and Roger Duthie. New York: SSRC, 2017.

Kagawa, Fumiyo and David Selby. Child-Friendly Schooling for Peacebuilding. New York: UNICEF, 2014.

Kavanagh, Camino and Bruce Jones. Shaky Foundations: An Assessment of the UN's Rule of Law Support Agenda. New York: New York University/Center on International Cooperation, 2011.

Keet, André and Felisa Tibbitts. "Curriculum Reform in Transitional Justice Environments: The South African Human Rights Commission, Human Rights Education and the Schooling Sector.” Internal Study. ICTJ Research Project: Transitional Justice, Education and Peacebuilding, 2015. 
Ladisch, Virginie and Joanna Rice. "Addressing the Recent Past in Schools: Reflections from Côte d'Ivoire.” In Transitional Justice and Education: Learning Peace, edited by Clara Ramírez-Barat and Roger Duthie. New York: SSRC, 2017.

Maalouf, Lynn and Christalla Yakinthou. "Grappling with Lebanon's Enduring Violence: Badna Naaref, an Intergenerational Oral History Project." In Transitional Justice and Education: Learning Peace, edited by Clara Ramírez-Barat and Roger Duthie. New York: SSRC, 2017.

Machel, Graça. The Impact of Conflict on Children. A/51/302. 26 August, 1996. UN Security Council Resolution 1612. 26 July, 2005.

Magill, Claire, Alan Smith, and Brandon Hamber. The Role of Education in Reconciliation. Ulster: University of Ulster, 2009.

Mazurana, Dyan and Khristopher Carlson. "Reparations as a Means for Recognizing and Addressing Crimes and Grave Rights Violations against Girls and Boys during Situations of Armed Conflict and under Authoritarian and Dictatorial Regimes." In The Gender of Reparations: Unsettling Sexual Hierarchies while Redressing Human Rights Violations, edited by Ruth Rubio-Marín. New York: Cambridge University Press, 2009.

McCully, Alan. "History Teaching, Conflict and the Legacy of the Past." Education, Citizenship and Social Justice 7 (2012): 145-159.

Michels, An. "Psychosocial Support for Children: Protecting the Rights of Child Victims and Witnesses in Transitional Justice Processes." Florence: Innocenti Research Centre/ UNICEF, 2010.

Murphy, Karen. "Educational Reform through a Transitional Justice Lens: The Ambivalent Transitions of Bosnia and Northern Ireland." In Transitional Justice and Education: Learning Peace, edited by Clara Ramírez-Barat and Roger Duthie. New York: SSRC, 2017.

Paulson, Julia. "The Educational Recommendations of Truth and Reconciliation Commissions: Potential and Practice in Sierra Leone." Research in Comparative and International Education 1 (2006): 335-350.

Paulson, Julia. "(Re)Creating Education in Postconflict Contexts: Transitional Justice, Education, and Human Development.” New York: ICTJ, 2009.

Paulson, Julia. "Truth Commissions and National Curricula: The Case of Recordándonos in Peru." In Children and Transitional Justice: Truth-Telling, Accountability and Reconciliation, edited by Sharanjeet Parmar, Mindy Jane Roseman, Saudamini Siegrist, and Theo Sowa. Cambridge: Harvard Law School and UNICEF, 2010.

Paulson, Julia, ed., Education and Reconciliation. Exploring Conflict and Post-Conflict Situations. London: Bloomsbury, 2011.

Paulson, Julia and Michelle J. Bellino. "Truth Commissions, Education, and Positive Peace: An Analysis of Truth Commission Final Reports (1980-2015)." Comparative Education 53 (2017): 313-332.

Quaynor, Laura J. "Citizenship Education in Post-Conflict Contexts: A Review of the Literature." Education, Citizenship and Social Justice 7, no. 1 (2012): 33-57.

Raggio, Sandra. “¿Historia o memoria en las aulas?” In Efemérides en la memoria. 24 de marzo, 2 de abril, 16 de septiembre. Propuestas para trabajar en el aula, edited by Sandra Raggio and Samanta Salvatori. Rosario: Homo Sapiens Ediciones Argentina, 2012.

Ramírez-Barat, Clara. Engaging Children and Youth in Transitional Justice Processes: Guidance for Outreach Programs. New York: ICTJ, 2012. 
Ramírez-Barat, Clara and Roger Duthie, eds., Transitional Justice and Education: Learning Peace. New York: SSRC, 2017.

Rodino, Ana María. "Teaching about the Recent Past and Citizenship Education during Democratic Transitions." In Transitional Justice and Education: Learning Peace, edited by Clara Ramírez-Barat and Roger Duthie. New York: SSRC, 2017.

Sandoval, Clara. "Transitional Justice and Social Change." SUR International Journal on Human Rights 20 (2014): 181-193.

Smith, Alan. Children, Education and Reconciliation. Florence: UNICEF Innocenti Research Centre, 2010.

Smith, Alan. "Education in the Twenty-first Century: Conflict, Reconstruction and Reconciliation." Compare 35 (2005): 373-391.

Smith, Alan and Tony Vaux. Education, Conflict and International Development. London: DIFD, 2003.

Staub, Ervin, ed. The Psychology of Good and Evil: Why Children, Adults and Groups Help and Harm Others. New York: Cambridge University Press, 2002.

Tawil, Sobhi and Alexandra Harley, eds. Education, Conflict and Social Cohesion. Geneva: International Bureau of Education/UNESCO, 2004.

UNESCO, Education for All Global Monitoring Report 2011: The Hidden Crisis: Armed Conflict and Education. Paris: UNESCO, 2010.

UNICEF Innocenti Research Centre/ICTJ. Children and Truth Commissions. Florence: UNICEF Innocenti Research Centre, 2010.

Weinstein, Harvey M., Sarah Warshauer Freedman, and Holly Hughson. "School Voices: Challenges Facing Education Systems after Identity-based Conflicts.” Education, Citizenship and Social Justice 2 (2007): 41-71.

Wilke, Christiane. "The Shield, the Sword and the Party: Vetting the East German Public Sector." In Justice as Prevention: Vetting Public Employees in Transitional Societies, edited by Alexander Mayer-Rieckh and Pablo de Greiff. New York: Social Science Research Council, 2009.

Wray, Dylan. "Facing the Past - Transforming Our Future: A Professional Development Program for History Teachers in South Africa." In Transitional Justice and Education: Learning Peace, edited by Clara Ramírez-Barat and Roger Duthie. New York: SSRC, 2017. 
Part I:

Designing and Implementing Educational Media and Materials for Transitional Justice 
Open-Access-Publikation im Sinne der CC-Lizenz BY 4.0

(c) 2018, V\&R unipress $\mathrm{GmbH}$, Göttingen 


\section{Creating Classroom Materials: Efforts to Open up a Debate about Colombia's Armed Conflict}

\section{Introduction}

How the past is remembered, forgotten, or silenced is always a highly contentious issue, and this is especially true in the classroom. The contents of educational media and textbooks in particular, as the main tools with which teachers develop their classes, convey important information about how a society chooses to deal with its past and about its willingness to strengthen its democracy by confronting a record of human rights violations. Sweeping such a reality under the carpet by hiding or denying certain facts and presenting a one-sided perspective of history usually continues to fuel the conflict from a different dimension, and in most cases it proves to be an unsuccessful approach. Wars are not exclusively fought on the battlefield; they can also expand culturally to permeate a society and can be reproduced via exclusionary, dogmatic, and stigmatizing narratives. A willingness to uncover and openly discuss about the past, on the other hand especially a past of which a country is not proud - can constitute a step forward that shows the willingness and capacity of a society to make changes and show its commitment to the non-recurrence of violence.

During their school years, students in Colombia only briefly touch upon the history of the armed conflict suffered by the country for the past 50 years. Students do not focus on this topic until the last two years of secondary school, when they are already 16 years of age. Moreover, the materials and textbooks used by teachers are generally not suitable for the purpose of dealing with such a complicated topic in the classroom. The existing textbooks do not provide enough space for the armed conflict to be studied in all its depth and complexity; nor is the portion of time allocated to the subject sufficient. Rather, the conflict is often approached from a detached perspective that succeeds neither in fostering empathy towards the victims nor in helping students develop critical thinking.

Several different groups have been involved in Colombia's armed conflict, changing their identities over time. The two main left-wing guerillas were the Armed Revolutionary Forces of Colombia (Fuerzas Armadas Revolucionarias de 
Colombia, FARC) and the National Liberation Army (Ejercito de liberación Popular, ELN). At the other end of the political spectrum, we could find rightwing paramilitaries with roots in vigilante groups set up by landowners and local businessmen for protection against the guerrillas during the eighties. The main group was the United Self-Defense Forces of Colombia (Autodefensas Unidas de Colombia, AUC), which was partially demobilized in 2005 as part of the Peace and Law Process. All parties engaged in the conflict, including the Colombian Armed Forces, have perpetrated numerous human rights violations. Between 1958 and 2012, 220,000 people died in the conflict, most of them civilians $(180,000)$, and more than five million civilians were displaced from their homes. Paramilitaries are blamed for massacres, forced disappearances, torture, and sexual violence while guerilla groups are responsible, mostly, for assassinations, kidnapping, and extortion. ${ }^{1}$ In October 2012, the government and the largest rebel group, FARC, launched peace talks. A final agreement was reached by the parties on 26 September, 2016, and signed in Cartagena, Colombia. This agreement, however, had still to be approved by popular vote. In the plebiscite that took place in Colombia on 2 October, the "no" vote to reject the accords won by a slight majority ( $50.21 \%$ vs. $49.78 \%$ ). Only $37.43 \%$ of Colombians turned out to the polls. These results are evidence of the high levels of polarization and skepticism that exist among the population and the enormous efforts required in the field of education to overcome the cultural legacies of war and embark upon a new path as a country. As Fernán Gonzales, a well known historian whose extensive academic work is already part of Colombian historiography, stated in an interview about the challenges to be considered and overcome when implementing these agreements, it is crucial to "work with people and help them understand both the causes of the conflict and the benefits the peace process could bring." ${ }^{\prime 2}$ As a society, Colombia failed to achieve this before the plebiscite took place. ${ }^{3}$

1 Centro Nacional de Memoria Histórica, $;$ Basta Ya! Colombia: Memorias de guerra y dignidad, Resumen (Bogotá: Pro Off Set, 2013). Work on this chapter was begun in 2015; while revisions reflect changes in the status quo that have occurred in the meantime, the data and core reflections presented here correspond to that time.

2 Alana Poole, "An Interview with a Leading Colombian Intellectual on the Peace Process," Peace Direct, http://www.insightonconflict.org/2015/11/interview-leading-colombian-in tellect-peace-process/, accessed 10 December 2015.

3 Subsequent to the results of the plebiscite, several analysts maintained that the defeat of the "yes" vote was related to the lack of pedagogical effort made to explain the contents and scope of the agreement. While in fact the content of the agreement was indeed explained via various pedagogical tools, I would argue that the problem lay in the failure to reach the entire population with the material, and particularly to convey to those who had not themselves experienced the war first-hand the extent of suffering and damage caused by the armed conflict across a large part of the country. It is in this context that a pedagogy of historical memory in the classroom acquires relevance. 
In the framework of the transitional justice process in Colombia that began in 2005 with the so-called "Justice and Peace Law," the Historical Memory Group which in 2011, with the passing of the "Victims Law," became the National Center for Historical Memory (Centro Nacional de Memoria Histórica, CNMH) began an investigation process throughout the country with the aim of understanding the dynamics that had fueled the war. Victims' narratives were attributed a core role in the process. In 2013, the group's comprehensive report, Basta Ya Colombia! Memorias de Guerra y Dignidad (Enough, Colombia! Memories of War and Dignity ${ }^{6}$ ), was submitted to Juan Manuel Santos, who had become president in 2010. By this time it was generally acknowledged that the nonrepetition of violence was dependent upon a process of addressing the history of the armed conflict within society; that via this process, a society might become capable of knowing, reflecting, and identifying the aspects of history that must not be repeated, thus strengthening its democracy and fostering peace. This chapter describes the participatory process with teachers that was begun in 2012 by the National Center for Historical Memory. In this process, the various reports and research findings produced by the Centre were converted into educational materials suitable for discussing the historical memory of the Colombian armed conflict in the classroom.

With regard to the rejection of the peace accord by the "no" vote in October 2016, various activists, researchers, and educationists have claimed that "the results and the high abstention rate reveal the failure of the Colombian education system because it has not been able to change the cognitive and moral structures of students."7 Similarly, Julián de Zubiría, a recognized expert on pedagogy in Colombia, argued after the "no" victory for the need to "recognize that education has not been able to mobilize $63 \%$ of Colombians to participate actively in building a better society. We have not been able to break his indifference. Nor have we been able to teach them to argue, to read critically, to write and to infer." De Zubiría continued that, according to the so-called "SABER tests," less than

4 Congreso de Colombia, "Ley 975 de 2005, por la cual se dictan disposiciones para la reincorporación de miembros de grupos armados organizados al margen de la ley, que contribuyan de manera efectiva a la consecución de la paz nacional y se dictan otras disposiciones para acuerdos humanitarios," Diario Oficial No. 45.980, 25 July, 2005.

5 Congreso de Colombia, "Ley 1448 de 2011, por la cual se dictan medidas de atención, asistencia y reparación integral a las víctimas del conflicto armado interno y se dictan otras disposiciones," Diario Oficial No 48.096, 10 June, 2011.

6 GMH, BASTA YA! Colombia: Memories of War and Dignity (Bogotá: CNMH, 2016), http:// www.centrodememoriahistorica.gov.co/descargas/informes2016/basta-ya-ingles/BASTAYA-ingles.pdf, accessed 29 January 2018.

7 Andrei Gomez-Suarez, "Peace Process Pedagogy: Lessons from the No-vote Victory in the Colombian Peace Referendum," Comparative Education 53, no. 3 (2017): 462.

8 A state examination taken twice annually by all eleventh-grade students from both state and 
$2 \%$ of the population was able to demonstrate "an advanced level of argumentation, deduction and inference ... Therefore, the main obstacle to peace in Colombia is not the FARC, but an educational system incapable of changing the ways of thinking, communicating and coexisting with future citizens."

Improving this situation involves many structural reforms and greater investment in the education system, particularly in teacher training. With this in mind, this chapter seeks to demonstrate the important role played by education in addressing historical memory as part of the challenging peacebuilding process beginning in Colombia. It helps to raise awareness among the indifferent, to cultivate empathy, and to generate bonds of solidarity; further, it inspires autonomy and the critical thinking necessary to face the multiple - often misrepresented - versions and narratives of Colombian history that circulate in the media, frequently undermining attempts to build peace.

Before focusing on the Colombian case, the chapter begins by examining how the representation of the violent past in the classroom has also been a matter of dispute in other countries such as Chile, Guatemala, and Spain. It then highlights the key features of the Colombian education system and provides a short overview of the armed conflict, subsequently discussing in detail a project put in place by the $\mathrm{CNMH}$ to create a set of classroom materials with which to address the war. The last section reflects on how these materials have been conceptualized and on the challenges faced by the $\mathrm{CNMH}$ during this process, especially those arising from the intention to bring the past into the classroom with the aim of contributing to democracy and peacebuilding.

\section{Struggles Surrounding Historical Narratives in the Educational Field}

Coming to terms with a past of massive human rights violations is not an easy endeavor. According to Eduardo González Calleja, "there is no doubt that the past is orchestrated for collective ends, the state elaborates and executes 'memory policies' in an implicit or explicit way, as an active policy or as an omission." 10 In the case of education policy, especially with regard to the history curriculum, certain political stances may beg for the silencing of specific his-

private schools across the country. Its objective is to evaluate the basic skills that all students are supposed to develop during their school career.

9 Julian de Zubiría, "El triunfo del NO y el fracaso de la educación colombiana," Semana, http://www.semana.com/educacion/articulo/implicaciones-del-no/497863, accessed 13 October 2017.

10 Eduardo González Calleja, Memoria e historia: vademécum de conceptos y debates fundamentales (Madrid: Los libros de la Catarata, 2013), 121. Author's translation from Spanish. 
torical aspects while others seek to render them more visible. In either case, how to deal with the past in the classroom is always a contentious issue that changes over time in accordance with specific contexts.

Examples of countries that have undergone turbulent political episodes, such as dictatorships or civil wars, illustrate very well how the educational field can become a place of dispute regarding versions of history built around an unedifying past. This has been shown by studies on the cases of Chile, Guatemala, and Spain. If we focus on the Chilean case, for instance, we can observe an intense discussion on the production of educational materials and what to convey to students about the period of Pinochet's rule. According to Leonora Reyes, after the establishment of the Commission for Truth and Reconciliation in 1990 and the delivery of the final report to President Patricio Aylwin in 1991, the Chilean historian Gonzalo Vial (also Minister of Education under the Pinochet regime from December 1978 to December 1979) was given the task of drafting the historical context to explain the previous 30 years of Chile's history. ${ }^{11}$ Vial's text stated that "it is not for the Commission to comment on the events that happened on 11 September, 1973. The 1973 crisis, in general, can be described as a sharp polarization where two entities ${ }^{12}$ - government and opposition - confronted each other."13

A year later, an ad hoc committee of the Ministry of Education was given the task of designing a new curriculum to be subjected to consultation and public discussion. In 1992, the commission submitted a first draft of the document before the process was interrupted by criticism from sectors of the political right and some members of the clergy, resulting in the immediate withdrawal of the document from public circulation. In 1996, the National Commission for the Modernization of Education (la Comisión Nacional para la Modernización de la Educación) resumed the task; however, as Julio Pinto, one of the team members, said, "there was a tactical analysis ... the framework program had to be approved by the Higher Council for Education, which is composed not only of the ministry but of a representative of the Church and a representative of the armed forces." 14

After all these disputes, what actually found its way into the classroom? Nowadays in Chile, the minimum contents of the obligatory curriculum do not

11 Leonora Reyes, "Actores, conflicto y memoria: Reforma curricular de Historia y Ciencias Sociales en Chile, 1990-2003," in Educación y memoria: la escuela elabora el pasado, edited by Elizabeth Jelin and Federico Lorenz (Madrid: Siglo XXI de España Editores, 2004), 65-93.

12 The expression that "two equal parties" were fighting each other has been used in different contexts. Equating the violence of guerrilla groups with that of military juntas has a long history in Latin America. Known as the "two demons theory," the idea seeks to obscure human rights abuses and to paper over crimes of the past.

13 Reyes, "Actores, conflicto y memoria," 72. Author's translation from Spanish.

14 Ibid., 73. Author's translation from Spanish. 
require students to study the period of the military dictatorship; however, they do include the neoliberal economic model that was established by Pinochet. Strictly speaking, while it is possible for a teacher to teach this period in the classroom without even mentioning that there was a state coup in Chile, he or she cannot, however, omit the economic aspects of the period in question because that would contravene what is stipulated in Decrees 220 and $240 .{ }^{15}$

This historical cherry-picking is problematic since many people in Chile identify Pinochet's rule with a period of economic prosperity, not necessarily aware of the massive human cost brought about by his rule. Further, the manner in which the past is represented in the curricula is a matter of dispute: Pinochet's era is referred to as a period of military governance rather than a dictatorship. This softer wording obfuscates the responsibility of the armed forces in the state coup that overthrew Salvador Allende's government in 1973 and in the systematic human rights violations that followed. The curriculum design fails to clearly communicate to students the tragedy represented by the Chilean dictatorship, nor does it convey the need to prevent the recurrence of such violence.

In Guatemala, the final peace accord in 1996 put an end to thirty-four years of war and created a Commission for Historical Clarification (Comisión para el Esclarecimiento Histórico, CEH). While in 1999, the CEH presented its final report, Memory of Silence, to the public, "the Guatemalan state did not take ownership of the report; on the contrary, three weeks after publication, President Arzú signed a full-page letter in the Guatemalan press repudiating many of the commission's recommendations." ${ }^{.16}$ To make matters worse, at the close of 1999, the party of the former head of state, General Efraín Ríos Montt (1981-83), who led the country during the worst years of the war, swept to power in presidential and congressional elections. Threats and attacks intensified against human rights activists and researchers who studied the armed conflict.

Despite this unfavorable political context, Oglesby argues that the influence of the CEH report can be seen in different ways, especially because many popular organizations took the commission's recommendations as their own and developed different educational projects that, in the non-formal sector, created a space for this history to become known. Nevertheless, as Oglesby identifies, when it comes to the reality of the classroom, "the actual use of the CEH report has been minimal. References to the report are almost always limited to the grim profiles of the violence, with little historical or social context to explain the conditions that gave rise to the armed conflict." Ultimately, Oglesby continues,

15 Ibid., 78.

16 Elizabeth Oglesby, "Educating Citizens in Postwar Guatemala: Historical Memory, Genocide, and the Culture of Peace," Radical History Review 97 (2007): 78. 
"the important issue is not the suppression of the report per se, but the ways in which certain portions of the report are repeated while others are muted."17

This reflection brings to the fore the question of why the violent past should be brought into the classroom. It should not be done in order to learn about the violence in itself; rather, it is to achieve some frame of understanding that can enlighten a society about the context and conditions that make violence possible in order to prevent its recurrence. In the Guatemalan case, in contrast to the Chilean situation, although the facts of the civil war are taught in schools and in some cases the victims' narratives are included in the textbooks, these narratives do not clarify where responsibilities lie, nor do they foster an understanding of the logic of discrimination and ethnic violence that brought about the war in the country. $^{18}$

A last example can be found in Spain. General Francisco Franco headed a coup d'état in 1936 that overthrew the democratically elected government of the Second Republic (1931-1936), giving rise to a civil war that lasted from 1936 to 1939. General Franco seized power, marking the beginning of the longest dictatorship in the history of Europe (1939-1975). When the process of transition finally brought democracy back to Spain in 1977, Spanish policymakers decided to adopt the strategy of oblivion and forgiveness in order to come to terms with the past and as means to move forward as a society. This "pact of silence," as it has often been called, was given legal form with the Amnesty Law of 1977. In spite of this, almost twenty years later and demonstrative of how dynamic such accords can be, since 2000 an increasing number of human rights organizations have attempted to reverse this process, highlighting the importance of bringing back memory and dealing with the past. ${ }^{19}$

In this context, an analysis of history textbooks in Spain carried out by Enrique Díez shows that the books fail to reflect significant events that took place after the defeat of the Republican side in the 1930s. The vacuum is, above all, in reference to the repression during the Franco regime and the role of those who continued to fight against the dictatorship until the mid-1960s. Most textbooks provide extensive details about the civil war and the various battles it entailed, emphasizing the confrontation between two equally evil entities, yet offering neither an explanation as to how the democratic project was overthrown nor the history of the anti-Franco resistance. ${ }^{20}$

17 Ibid., 78-79.

18 Ibid., 77-98.

19 For more on this process see, for example, Stephanie Golob, "Volver: The Return of/to Transitional Justice Politics in Spain," Journal of Spanish Cultural Studies 9, no. 2 (2008): 127-141; and Omar Encarnación, "Reconciliation after Democratisation: Coping with the Past in Spain," Political Science Quarterly 123, no. 3 (2008): 435-459.

20 Enrique Díez, "Educando la memoria de las jóvenes generaciones: el olvido escolar de la II 
Diez shows conclusively that although the Second Republic, the Civil War, and the Franco regime lasted together more than 50 years, they account for only $10 \%$ of the 20th-century contents in the most widely used textbooks. Of that $10 \%$, the largest portion of space is dedicated to the description of the civil war, while other aspects such as the repression of the dictatorship, the anti-Franco resistance, and the republican cause, are hidden. As Diez correctly states, these gaps or omissions are far from innocent ${ }^{21}$ in the context of Spain, anything "registered" in school textbooks was loyal to the "pact of silence" made during the transition period. The contents taught failed to raise awareness of this crucial period in Spanish history. Generally speaking, teenagers of today do not necessarily have knowledge of them, at least not from reflections on the past carried out in school.

\section{The Colombian Case}

If teaching recent history is a contested question in countries seeking to overcome violent pasts, the case of Colombia is arguably even more complex because the war has not yet come to an end. Multiple versions of the past are still pugnaciously competing for a place in the historical record. The history of the armed conflict that has lasted for more than 50 years is still somewhat neglected in the teaching of social sciences in both primary and secondary education. However, at this crucial point in Colombia's history, in the midst of a peace process, schools in the country can choose to either contribute to constructing memories of the conflict from a democratic framework or, conversely, sustain the war ideology by using exclusionary, dogmatic and stigmatizing narratives.

The education system of Colombia is decentralized. There is neither an official curriculum, nor are official compulsory textbooks issued for schools across the country. Schools are able to autonomously design their own Institutional Educational Project (Projecto Educativo Institucional, PEI) according to the specific contexts with which they find themselves confronted. Notwithstanding this decentralization, in 2006 the National Ministry of Education issued a set of Basic Competence Standards ${ }^{22}$ that specify what students must learn in the compulsory areas of language, mathematics, sciences and citizenship education in different learning cycles. ${ }^{23}$ These competences include the guidelines teachers receive to

República y de la barbarie franquista," in Lecciones contra el olvido, edited by Carlos Lomas (Barcelona: Ediciones Octaedro, S.L., 2011), 225-258.

21 Díez, "Educando la memoria," 225-258.

22 Ministerio de Educación Nacional, Estándares Básicos de Competencias en Lenguaje, Matemáticas, Ciencias y Ciudadanas (Bogotá: Imprenta Nacional de Colombia, 2006).

23 There are five learning cycles: first to third grade, fourth to fifth, sixth to seventh, eighth to ninth and tenth to eleventh grade. 
design their classes for each learning cycle, and schools must also take them into account when developing their PEIs. State evaluations made to determine the quality of schools are based on these standards. Thus, even in the absence of an official curriculum, these standards provide guidance regarding the issues to be addressed by teachers in the classroom and the abilities that their students should acquire.

What space does the history of the armed conflict in Colombia occupy according to these standards? In each learning cycle students must be able to develop competencies specified in three categories. The first requires students to develop research capabilities; the second stipulates the content-matter that students must learn during each cycle; and the last refers to the development of personal and social competencies. The Colombian armed conflict as a subject of study is allocated no space in any of the first four learning cycles. This means that students aged approximately from 7 to 15 neither hear of, nor reflect on, the armed conflict in the classroom at all. Moreover, no orientation is provided by the Ministry of Education to specify what students should learn about the armed conflict during these four cycles. From this perspective, the information and ideas that students absorb regarding the conflict are only partial, as they develop on the basis of what students learn at home, from the media, from television soap operas set in this context, and from sporadic news items that are difficult for them to contextualize.

The armed conflict appears as a topic for study only within the last learning cycle, applying to students of 16 years and above. In the last two years of school, in the tenth and eleventh grades, students must learn topics centered around 30 competencies that are part of the section called "management of knowledge belonging to social sciences." These topic areas cover historical world events of the 20th century (primarily the two World Wars and the Middle East conflict) to the struggles of ethnic groups within Colombia and Latin America, dictatorships within Latin America in the 20th century, artistic manifestations, economic theories, globalization, etc. ${ }^{24}$ Of all these topics, only 4 of the 30 competencies established in the Standards relate to the armed conflict in Colombia. A simple mathematical calculation shows that, since the 30 competencies to be covered during the last two years of schooling are divided across the two years with 15 in each, by the end of the cycle a total of only two months will have been dedicated to the Colombian armed conflict. Students thus graduate from school and begin their college or working life without knowing the most significant facts to have shaped the recent history of the country, or the suffering experienced by their fellow citizens as a result of the war.

24 Ministerio de Educación Nacional de Colombia, Estándares Básicos de Competencias, $130-131$. 
The picture does not much improve even if we take a look at some of the most widely used textbooks in the country. ${ }^{25}$ The publishing houses refer to the Standards provided by the Ministry of Education when designing the textbooks and, with these as a reference, they must provide material to cover the wide range of subjects presented. Even following revisions, the textbooks still fail to dedicate more than $10 \%$ of their contents to the armed conflict and, even here, its victims remain invisible.

Teachers do not generally lean on a single textbook when preparing their classes. They additionally consult historical sources or more complex books written by experts, which due to their complexity may not necessarily be suitable for grades ten and eleven. While there are exceptions, and indeed the decentralization and flexibility of the Ministry of Education has allowed some teachers to cover this issue in more depth, ultimately it remains a voluntary matter rather than a systematic practice arising from a public policy on education committed to teaching a violent past.

With the aim of addressing this deficiency, the $\mathrm{CNMH}$ decided to develop materials based on the various reports it had commissioned, with the aim of facilitating classroom discussion about the historical memory of the armed conflict and helping interested teachers address the issue more directly. Certain challenges still lie between the materials and their use in schools; ongoing struggles within the work of the Center render negotiations with a variety of actors necessary, including public servants from the Ministry of Education and the teachers themselves.

What are Schools Missing and Why is it Important to Bring the Violent Past into the Classroom?

In 2005, when the transitional justice process began in Colombia, the victims of the conflict were not part of the public agenda, nor was there any recognition on the part of the Alvaro Uribe government (2002-2010) regarding the existence of an armed conflict. After failed peace talks (1998-2002), President Uribe launched a strategy to demobilize paramilitary groups and the Congress approved Law number 975, or the so-called "Justice and Peace Law," which included the cre-

25 See, for example, Estrategias en Ciencias Sociales 10 (Bogotá: Editorial Libros \& Libros S.A., 2010); Estrategias en Ciencias Sociales 11 (Bogotá: Editorial Libros \& Libros S.A., 2010); Norma. Sociales para pensar 10 (Bogotá: Grupo Editorial Norma 2011); Norma. Sociales para pensar 11 (Bogotá: Grupo Editorial Norma 2011); Los Caminos del Saber: sociales 10 (Bogotá: Editorial Santillana, 2012); Los Caminos del Saber: sociales 11 (Bogotá: Editorial Santillana, 2013); Avanza sociales 10 (Bogotá: Carvajal Soluciones Educativas S.A.S., 2014); and Avanza sociales 10 (Bogotá: Carvajal Soluciones Educativas S.A.S., 2014). 
ation of the National Commission for Reparation and Reconciliation (CNRR), in 2005. The CNRR was responsible, among other things, for the public documentation of why and how illegal armed entities had risen and become established in Colombia since 1964. Considering the enormous Task involved in the process of $\mathrm{DDR}^{26}$ among the paramilitary groups, the CNRR decided to delegate the production of the report to the Historical Memory Group (HMG), an independent academic team put together under the leadership of Gonzalo Sánchez. ${ }^{27}$ In 2010, Juan Manuel Santos was elected President and lobbied intensively for congressional approval of what is now known as the Law of Victims and Land Restitution (Law 1448 of 2011). This law explicitly sees historical memory reconstruction as part of the rights of victims to symbolic reparation and truth, and established the Centro Nacional de Memoria Histórica (CNMH) to carry out this task. The CNMH, under Gonzalo Sánchez's direction, builds on the work undertaken by the HMG.

Well aware of the complexity of the Colombian war and the variations in its narrative from one region to another, Gonzalo Sánchez designed a methodology that allowed for the production of reports about "emblematic cases." An emblematic case focuses on a particular event, a specific aspect that fueled the conflict - such as a massacre, the disappearance of a leader, or kidnapping, etc. and it uses it to reconstruct the dynamics of war around it. Its lessons go beyond the case itself, also shedding light on other examples where conflict was exacerbated by the same element. The reconstruction of emblematic cases has shown the dynamism and the complexity of the war in Colombia. The HMG decided to move from a traditional historical research endeavor toward an approach that combined data collection and the rigorous use of historical sources with an interest in the voices of victims, seeking to provide a dignified public space for their memories within the national narrative of war. In more than 30 reports, ${ }^{28}$ the $\mathrm{HMG}$ and $\mathrm{CNMH}$ have developed a comprehensive narrative of the causes, emergence, and escalation of the internal armed conflict, armed groups, and their competing claims. Following these efforts toward historical clarification, the $\mathrm{CNMH}$ ascertained that nothing would be accomplished if all the books remained in libraries, only to be read by social workers, academics, or

26 Abbreviation for "Disarmament, Demobilization and Reintegration."

27 Gonzalo Sánchez Gómez, the current director of the CNMH, has a long history of investigating the armed conflict in Colombia and documenting its effects. Most of his academic work has revolved around understanding the conflict and violence in Colombia. He belongs to the group known in Colombia as the "violentologists" (violentólogos), experts on the period known as "The Violence" in Colombia (1946-1958). In 2007 he was appointed director of the Historical Memory Group that became what is today the CNMH.

28 The reports can be consulted at http://www.centrodememoriahistorica.gov.co/informes, accessed 29 January 2018. 
human rights advocates. Rather, the books needed to be visible within society as a whole if they were to contribute to non-repetition. Based on this premise, the CNMH set up a Pedagogical Team in 2012, led by Maria Emma Wills ${ }^{29}$ and comprising eight others, with the mission to promote public debate and facilitate social appropriation of the Center's research findings. Well aware of the strategic position held by schools in the accomplishment of this task, the Pedagogical Team began to build a teacher's toolbox aimed at facilitating learning and classroom discussion about Colombia's violent past.

\section{Efforts toward Teaching Colombia's Violent Past}

The CNMH teacher's toolbox, Un viaje por la memoria histórica. Aprender la paz. Desaprender la Guerra (A journey through historical memory. Learn peace. Unlearn the war), is a set of materials that facilitates work and discussion in the classroom on the historical memory of the Colombian armed conflict. It makes pedagogical use of the reports produced by the $\mathrm{CNMH}$ with the aim of fostering empathy, critical thinking, and respect for human rights. The toolbox contains five books. Two of the textbooks for students are inspired by two of the CNMH's emblematic case reports: the El Salado and Bahía Portete massacres. Both textbooks come with a teacher guide for use in the classroom.

The first book, Los caminos de la memoria (the memory roads) is a book for teachers that acknowledges their participation and contributions to the process, offers theoretical support and various pedagogical activities to be developed freely in the classroom. The second is a textbook for students in tenth and eleventh grades inspired by the CNMH report on the El Salado massacre, with, thirdly, a separate teacher's guide. The fourth is a textbook for students in tenth and eleventh grades based on the $\mathrm{CNMH}$ report on the Bahía Portete massacre, also with a teacher's guide. Additionally, the toolbox comes with a set of 10 flashcards for teachers and the children's story about forced displacement, Un largo camino (a long way) written by Beatriz Vallejo. ${ }^{30}$

The toolbox design included insights from and the active participation of

29 María Emma Wills is an advisor to the director of the CNMH and the Pedagogy Team coordinator. She worked as a researcher for several years at the Center for Research and Popular Education (CINEP), then in the Department of Political Science at Andes University and the Institute of Political Studies and International Relations at the National University of Colombia. In 2008 she became a member of the Historical Memory Group and, in 2015, she was the only woman on the Historical Commission of the Conflict and its Victims that was established in the context of peace process negotiations between FARC and the government of Colombia in Havana, Cuba.

30 All these different materials can be consulted and downloaded here: http://www.centro dememoriahistorica.gov.co/informes/informes-2015-1/un-viaje-por-la-memoria-historica. 
teachers from different regions of the country. This collaboration was crucial to the process, especially considering that in a context of ongoing war teachers best know their daily contexts and the challenges to be faced when initiating a classroom discussion on the armed conflict. From 2013 to 2015, teachers from different parts of the country participated in different stages of the process. To date, the $\mathrm{CNMH}$ has worked on this project together with some 300 teachers from nine different departments and 20 municipalities of Colombia. ${ }^{31}$ The majority were teachers of the social sciences in public schools, while in Bogotá work was carried out with teachers in private elite schools belonging to the Unión de Colegios Internacionales, UNCOLI (Association of International Schools).

The project was launched in 2013. During this first year, the work focused on designing the preliminary materials with the active participation of teachers in El Chocó, Arauca, and La Guajira. Seven workshops in total were carried out with the aim of exploring, together with the teachers, their perceptions of the armed conflict and the level of importance they attached to the treatment of the armed conflict as a subject in their classrooms. In the course of this process, the teachers expressed ideas as to how to teach the findings of the various $\mathrm{CNMH}$ reports. In 2014, the Pedagogical Team continued to work with teachers from these areas, while significant efforts were made to validate and expand upon the first materials designed with educators from other regions. During this period, workshops were undertaken with teachers from El Putumayo, Antioquia, Bogotá and Bolívar. With such a variety of input from fieldwork with teachers and the challenges identified (to be explained in detail below) a first edition of the toolbox was published in August 2015. Following workshops in 2016 and 2017 on how to use the toolbox, 94 schools decided to implement it in their classrooms.

This preliminary work conveyed many important lessons, revealing various challenges that required consideration when creating the final materials. Particularly the collaboration with teachers revealed three important aspects:

First, the work confirmed that silence surrounding the armed conflict has become instituted in the classroom. Most teachers avoid speaking about it. In the case of textbooks, as mentioned above, there are only very few references to Colombian history from the 1950s to the present. The resulting combination of these poor quality textbooks and the Standards produced by the Ministry of Education is that the violent past remains an unacknowledged theme in the

31 Colombia is geographically divided into 32 departments (departamentos), each of which is divided into municipalities (municipios), which are smaller geographical territories. The departments in which the project was carried out with teachers, with corresponding municipalities in brackets, are: Arauca (Tame, Arauca, and Saravena), Chocó (Quibdó and Bojayá), Guajira (Riohacha and Uribia), Putumayo (Valle del Guamuez) Antioquia (Medellín and Bello), Cauca (Mercaderes, El Bordo, and El Tambo), Huila (Guadalupe and San José de Isnos), Nariño (Samaniego and Pasto), Bolívar (San Juan Nepomuceno y Salado), and Bogotá. 
classroom, and even when teachers are willing to address the subject they do not have access to the appropriate classroom materials with which to do so.

Second, the work with the teachers also revealed that, while some teachers do talk about the armed conflict in the classroom, they do so in a problematic manner. The messages they convey are rather more shaped by ingrained beliefs than by nuanced perspectives or an awareness of the complexities inherent in the history. The study revealed that teachers tend to be anchored within their local contexts and often rather politicized. Some teachers who have decided to address the armed conflict in the classroom do so by reproducing their own mental frameworks, thus reflecting the polarization and dogmatization resulting from the war. An example of this can be found in Arauca, a region of Colombia that is rich in oil and thus a base for several multinational corporations. Teachers understand the conflict in the region through this lens, commenting, for example, that "the origin and permanence of the conflict in Arauca is due to Yankee imperialism." During the workshops, members of the CNMH Pedagogical Team would ask "Why is it then, that other countries with the presence of the United States and multinational corporations do not have an armed conflict?" The purpose of this kind of intervention was to challenge common beliefs that are neither necessarily true nor underpinned by empirical facts. In Arauca and other regions, the Pedagogical Team worked with teachers to help them transform such statements into hypotheses. Taking this into account, one of the main aims of the teacher's toolbox is to provide methodological materials that can teach teachers to carry out thorough research and come to their own conclusions, ultimately learning how to question their own preconceptions about the armed conflict. Consequently, the purpose is not only to inform teachers about the traumatic events that occurred in different parts of Colombia; it is to develop a guide for both teachers and students to develop critical thinking and the habit of testing their own thoughts and beliefs.

Third, the teachers spoke of the apathy and lack of interest on the part of their students with regard to history. Because of the differentiated development of the war in Colombia, the way it has been perceived in different regions also varies. For instance, in urban and wealthy areas students feel the armed conflict has nothing to do with them. This apathy needs to be addressed and taken into account when designing materials.

The two emblematic cases selected (El Salado and Bahía Portete) place a different emphasis on aspects that have fueled war in Colombia. As stated by Fernán Gonzales,

The Colombian conflict is not a religious war. Nor is it a civil war defined by clear black and white lines. It is a conflict with different modalities in different regions, not a fight 
against specific or rigid determinants. And it demonstrates a very complex and complete set of dynamics for which we need to work in a different way. ${ }^{32}$

In order to understand the war in Colombia it is necessary to get into the dynamics of the conflict in different regions. El Salado is a little town in the department of Bolívar in the mountainous region of Montes de María. Between February 16 and 21, 2000, El Salado was the scene of a massacre. Some 450 paramilitaries entered the town, forced all those present to go to the soccer field, and massacred 60 people at random while the others were watching as a "message of punishment" for all. Because of its history, struggles, and the strong presence of guerrilla troops, this whole town was stigmatized, by both the state forces and paramilitary groups, as a "guerilla town." The violence was intended to punish a town in which everyone was suspected of belonging to the guerrillas. ${ }^{33}$

The massacre of Bahía Portete, located in the department of La Guajira, reveals the impact of the violent conflict among native groups. Ethnic and gender discrimination point to the strategic warfare methods of armed entities. Paramilitaries were seeking control over this port in the north of Colombia, important for trafficking drugs and guns, a territory inhabited and controlled by the Wayuu indigenous group since 1920. In order to destroy the rule and order of the community and take control over the port, paramilitaries abused and massacred women, spread terror, and organized a massive displacement of the indigenous population. This case, reconstructed in one of the CNMH reports, ${ }^{34}$ shows ethnic and gender discrimination. The objective in addressing these events is that students identify how armed conflict has annihilated ethnic diversity in Colombia, recognize the value of that difference, and appreciate the enriching aspects of various native groups in Colombia.

\section{Some Insights Regarding the Challenges of Designing Educational Materials}

Why are we bringing the violent past into the classroom? Why do we do so via historical memory? A history of pardons and amnesty shows how various societies have considered the best way of coming to terms with the past to be one of forgetting and ignoring highly sensitive wounds that could unleash new cycles of

32 Alana Poole, "An interview with a leading Colombian intellectual on the peace process."

33 CNRR-Grupo de Memoria Histórica, La Masacre de El Salado, Esa guerra no era nuestra (Bogotá: Ediciones Semana, 2009).

34 CNRR-Grupo de Memoria Histórica, La Masacre de Bahía Portete, Mujeres Wayuu en la mira (Bogotá: Ediciones Semana, 2010). 
violence, the decision taken by policymakers in Spain during the seventies being a paradigmatic example of such an approach. With the transitional justice framework, however, this method is being increasingly abandoned, with the realization that "societies that choose not to address past human rights abuses or other forms of severe trauma (including their root causes and enduring consequences) risk undermining their efforts of socioeconomic reconstruction and their transition to a more democratic and peaceful future." ${ }^{\prime 35}$

In order to prevent the recurrence of violence, it is necessary to identify and name what we do not want to repeat. As Karen Murphy has argued, "democracy is not an intuitive system: Learning to become a democratic citizen is not something one learns just by being in society. There is both procedural knowledge to learn (a new constitution, for example) and behaviors and dispositions that must be developed and practiced." ${ }^{36}$ In order to build a sustainable peace, the education system needs to be "synchronized with the aims of peacebuilding and conflict prevention by sensitizing younger generations to the values, attitudes, and skills necessary for peace and tolerance. ${ }^{\prime 37}$ When devising methods to teach the violent past, it is crucial to ensure that the goals of bringing the violent past into the classroom are aligned with methodologies and didactic activities that promote a culture of empathy, critical thinking, and debate that reinforce democracy and human rights norms. The content of the materials designed and the way in which they are put together should remain focused on the goal to bring the recent past into the classroom. If we want to inspire a debate, we cannot continue to edit textbooks based on the logic of "right answers" that students have to memorize and recall during an exam in order to achieve good marks. If we want to strengthen democracy we cannot write materials from one perspective, excluding others; rather, we must recognize the plurality of voices.

Taking this perspective into account, three aspects guided us when creating the educational materials:

1. Generating a Connection between the Contents of History and what is Meaningful to Students

Experiences with teachers and students in Colombia reveal a general lack of interest in history on the part of young people, a clear disconnection based on the assumption that history has nothing to do with them. All materials produced by

35 Clara Ramírez-Barat and Roger Duthie, Education and Transitional Justice, Opportunities and Challenges for Peacebuilding (New York: ICTJ and UNICEF, 2015), 1.

36 Karen Murphy, "Education and Transitional Justice," presentation at ICTJ, New York, June 23, 2011 and quoted from Ramírez-Barat and Duthie, Education and Transitional Justice, 18.

37 Ramírez-Barat and Duthie, Education and Transitional Justice, 4. 
the Center must take this into account and face the challenge of how to awaken young people's interest in contents that might appear dull at first glance. To address this challenge, the toolbox textbooks have carefully considered entry points. Each textbook chapter has an opening section with space for situations faced by students in their daily lives that are related to the historical contents to be addressed in the following pages. For example, the first chapter of the El Salado textbook is about the history of peasants in Montes de María. The chapter explores the bonds and knowledge peasants develop regarding the land they inhabit. It also explains how the land was distributed around 1960 and about the conflicts between peasants and landowners at that time. The idea behind this first chapter is to address the relationships between the places people inhabit and their identities. Taking this into account, the first section of this chapter is dedicated to reflecting with students on which places are important for them and the conflicts they have experienced with regard to those places.

Once the students have considered why they might have important bonds with some places and how these might be related to the development of their own identities, they move on to the next section of the chapter. Here they can see how other people, particularly peasants of the Montes de María region, are deeply connected with the place they inhabit and shaped by their own struggles with other groups. The purpose of these opening sessions is to render students aware of the connection between social, historical, and personal issues. It also helps to build a bridge between the content matter to be addressed and the student's own everyday life.

\section{Recovering the Student's Sense of Agency}

Another problem uncovered by the project is what de Roux has called "the bronze history," 38 a history made by large characters, by "heroes," presidents, and kings. One of the difficulties inherent in teaching history in this way is that students gain the impression that history is not made by ordinary people like themselves, thus eliminating any sense of agency. In contrast, history can be taught in such a way that young people can envisage shaping history through their actions and decisions, and that there is something they can do to make a change.

This problem is addressed by the textbooks in the toolbox in two ways. First, the students are invited to see that the characters who shape history are ordinary people not usually found in traditional textbooks: peasants, members of civil

38 Rodolfo de Roux, "La insolente longevidad del héroe patrio," Caravelle 72, no. 1 (1999): 31-43. 
society, women, teachers, and youngsters who took different paths in life. While of course laws and presidents are also present, the message conveyed is that history is made by many different actors, not exclusively by those with power as depicted by traditional textbooks.

Second, the El Salado and Bahía Portete textbooks conclude with an exercise that directly invites students to take action. They are faced with the question as to what they themselves can do from their own contexts and situations, and how they can contribute to the non-recurrence of these violent events. Learning and believing that one can have an impact on history fosters accountability for decisions taken and the consequences of these decisions, both for one's own life and for the lives of others.

\section{Developing Materials that Stimulate Critical Thinking and Empathy}

As Angela Bermúdez argues, "teachers appreciate the general notion of critical thinking, but they find it hard to translate into a specific pedagogy ... in spite of this wide appeal, research shows that critical deliberation is rare in the classroom, and when it does happen, it is often of low quality." 39 Acknowledging the political interests of teachers was a crucial part of this process to create materials that challenge not only students' beliefs, but also teachers' own preconceptions. The pedagogical design of the materials seeks both to facilitate critical thinking in the classroom and to challenge teachers to move from the position of purveyors of knowledge to one where they encourage the construction of knowledge and thus empower students.

In order to accomplish this, the textbooks are not narrated by a third-person voice that recounts the history of what has happened $;^{40}$ instead, they encourage students to come to their own conclusions based on their exposure to different sources. The textbooks guide the students through different sources referring to certain subjects: speeches given by politicians, press articles, testimonies, graphs, legislation excerpts, and so on. These different sources present different points of view, reveal historical struggles, and the challenges faced by different people and groups. The students then face different questions with which to contrast and compare these different points of view and come to their own conclusions. In this way, the textbooks are designed to engage the students in a methodical inquiry where they develop an acute awareness of the process by

39 Angela Bermúdez, "Four Tools for Critical Inquiry in History, Social Studies, and Civic Education," Revista de Estudios Sociales 52 (2015): 103.

40 This type of writing, the most prevalent in traditional textbooks, does not encourage critical thinking. It leads students to memorize and provide the answers that they know the teacher is looking for. 
which they reach certain conclusions. This methodology is also consistent with the endeavors of $\mathrm{CNMH}$ to avoid fostering any official memory or history. It was not intended, however, to be an exclusively intellectual endeavor; emotions played a crucial role. Emotions are often regarded as obstacles that disrupt and confuse our thinking, rendering us prone to impulsiveness, error, and distortion. Interestingly, however, as Matthew Lipman and other scholars contend, emotions are not necessarily "psychological storms" or "murky clouds"; rather, they can be important sources of understanding as they "heighten our awareness, redirect our attention, and provide patterns of sensibility." 41

The toolbox textbooks are dedicated to emblematic cases that occurred in places that most Colombians did not know existed. These cases render visible what had remained invisible for years and they do so with the victims' voices at the core of each report. Students are expected to be emotionally moved by the testimonies in these textbooks that reveal the enormous suffering on the part of their fellow citizens. Even though these testimonies of violations were carefully selected in order to avoid saturating the textbook with them, they are present alongside questions seeking to encourage empathy and the capacity "to put yourself in another's shoes."

This project of the $\mathrm{CNMH}$, the historical memory toolbox for teachers, recognizes that, in a conflict-ridden country such as Colombia, the project to strengthen democracy and build a peaceful future requires society as a whole, and particularly teachers and students, to be able to identify, verbalize, understand and debate the historical roots and aspects that need to be transformed in order to break repeating cycles of violence. To this end, the classroom materials designed in this project promote an empathic connection with victims, a rigorous understanding of history, and a journey during which students acknowledge their sense of historical agency. The historical memory endeavor is intended to foster qualities such as precision, coherence, consistency, and knowledge based on evidence to construct a deep understanding of historical events as well as to compel students to move from indifference to taking action, as far as they can, in their daily lives.

In a nutshell, the materials created encourage reflective processes regarding the Colombian violent past that promote a detailed understanding of the logics and complexities of the war and a committed citizenry. Given that these materials do not literally translate the $\mathrm{CNMH}$ reports into booklets for students but rather promote a path of inquiry with which students can develop a critical, informed and empathetic view of history, it is hoped that they will contribute to fostering and maintaining open and democratic debate in the

41 Angela Bermúdez, "Four Tools for Critical Inquiry," 107; Matthew Lipman, Thinking in Education (Cambridge: Cambridge University Press, 2003). 
classroom. Such a debate must address both our collective past and present as a country in an arena of complex struggle regarding different versions of a contested history.

\section{Bibliography}

Avanza sociales 10. Bogotá: Carvajal Soluciones Educativas S.A.S., 2014.

Avanza sociales 11. Bogotá: Carvajal Soluciones Educativas S.A.S., 2014.

Bermúdez, Angela. "Four Tools for Critical Inquiry in History, Social Studies, and Civic Education." Revista de Estudios Sociales 52 (2015): 103.

$\mathrm{CNMH}$, $B$ Basta Ya! Colombia: Memorias de guerra y dignidad, Resumen. Bogotá: Pro Off Set, 2013.

CNRR-Grupo de Memoria Histórica, La Masacre de El Salado, Esa guerra no era nuestra. Bogotá: Ediciones Semana, 2009.

CNRR-Grupo de Memoria Histórica, La Masacre de Bahía Portete, Mujeres Wayuu en la mira. Bogotá: Ediciones Semana, 2010.

De Roux, Rodolfo. "La insolente longevidad del héroe patrio." Caravelle 72, no. 1 (1999): 31-43.

De Zubiría, Julián. “El triunfo del NO y el fracaso de la educaci_n colombiana.” Semana, 10 October 2016, http://www.semana.com/educacion/articulo/implicaciones-del-no/497 863. Accessed 13 October 2017.

Díez, Enrique. "Educando la memoria de las jóvenes generaciones: el olvido escolar de la II República y de la barbarie franquista." In Lecciones contra el olvido, edited by Carlos Lomas. Barcelona: Ediciones Octaedro, S.L., 2011, 225-258.

Estrategias en Ciencias Sociales 10. Bogotá: Editorial Libros \& Libros S.A., 2010.

Estrategias en Ciencias Sociales 11. Bogotá: Editorial Libros \& Libros S.A., 2010.

Gomez-Suarez, Andrei. "Peace Process Pedagogy: Lessons from the No-vote Victory in the Colombian Peace Referendum.” Comparative Education 53, no. 3 (2017): 462.

Gonzáles, Eduardo. Memoria e historia: vademécum de conceptos y debates fundamentales (Madrid: Los libros de la Catarata, 2013).

Lipman, Matthew. Thinking in Education. Cambridge: Cambridge University Press, 2003.

Ministerio de Educación Nacional, Estándares Básicos de Competencias en Lenguaje, Matemáticas, Ciencias y Ciudadanas. Bogotá: Imprenta Nacional de Colombia, 2006.

Norma. Sociales para pensar 10. Bogotá: Grupo Editorial Norma, 2011.

Norma. Sociales para pensar 11. Bogotá: Grupo Editorial Norma, 2011.

Oglesby, Elizabeth. "Educating Citizens in Postwar Guatemala: Historical Memory, Genocide, and the Culture of Peace." Radical History Review 97 (2007): 77-98.

Poole, Alana. "An Interview with a Leading Colombian Intellectual on the Peace Process." Peace Direct. http://www.insightonconflict.org/2015/11/interview-leading-colombianintellect-peace-process. Accessed 10 December 2015.

Ramírez-Barat, Clara and Roger Duthie. Education and Transitional Justice: Opportunities and Challenges for Peacebuilding. New York: ICTJ and UNICEF, 2015.

Reyes, Leonora. "Actores, conflicto y memoria: Reforma curricular de Historia y Ciencias Sociales en Chile, 1990-2003.” In Educación y memoria: la escuela elabora el pasado, 
edited by Elizabeth Jelin and Federico Lorenz. Madrid: Siglo XXI de España Editores S.A., 2004, 65-93. 
Open-Access-Publikation im Sinne der CC-Lizenz BY 4.0

(c) 2018, V\&R unipress $\mathrm{GmbH}$, Göttingen 


\section{Beyond Transitional Justice: Evaluating School Outreach and Educational Materials in Postwar Rwanda and Sierra Leone}

\section{Introduction}

In recent years, outreach has become an important aspect of transitional justice (TJ). Truth commissions and criminal tribunals across the globe have increasingly been implementing public education programs on transitional justice processes in order to inform and involve affected communities and to ensure local ownership. ${ }^{1}$ Of late, attention has also been paid to reaching out to younger generations. This novel development in transitional justice practice comes as the result of increasing efforts to involve children and young people in TJ in view of their position both as particularly vulnerable groups in war contexts and as key stakeholders in postwar recovery. ${ }^{2}$ Various initiatives have simultaneously attempted to intensify the impact and sustainability of such initiatives by connecting TJ outreach with formal education systems.

While specialized literature investigating and evaluating TJ outreach programs and their impacts on macro and micro levels has begun to emerge, little remains known about outreach efforts targeted toward youth, and particularly schools, and their efficacy. This chapter seeks to help fill this lacuna by investigating specific instances of bridgebuilding between transitional justice work and the education sector. It will analyze educational materials produced within the context of TJ outreach programs aimed specifically at young people, and

1 Janine Natalya Clark, "International War Crimes Tribunals and the Challenge of Outreach," International Criminal Law Review 9 (2009): 99-106; Wendy Lambourne, "Outreach, Inreach and Civil Society Participation in Transitional Justice," in Critical Perspectives in Transitional Justice, edited by Phil Clark (Cambridge: Intersentia, 2013), 235-261; Clara Ramírez-Barat, Making an Impact. Designing and Implementing Outreach Programs for Transitional Justice Measures (New York: ICTJ, 2011).

2 Sharanjeet Parmar et al., eds., Children and Transitional Justice. Truth-Telling, Accountability and Reconciliation (Cambridge: Harvard University Press, 2010); Clara Ramírez-Barat, Engaging Children and Youth in Transitional Justice Processes: Guidance for Outreach Programs (New York: ICTJ, 2012); Clara Ramírez-Barat, ed., Transitional Justice, Culture and Society: Beyond Outreach (New York: Social Science Research Council, 2014). 
discuss two unique and thus far under-studied initiatives conducted in two African countries recently emerging from war and mass violence.

The first of these initiatives is the 127-page Senior Secondary School Version of the Sierra Leonean Truth and Reconciliation Commission's (SLTRC) Final Report. ${ }^{3}$ The book, published in 2005 , was produced by a local civil society network called the Truth and Reconciliation Working Group (TRWG) in the wake of the decade-long civil war that raged in the small West African country between 1991 and 2002, killing an estimated 70,000 and forcibly displacing half the remaining population. ${ }^{4}$ It represents a response to a recommendation made by the SLTRC to integrate the findings of its investigation of the war into the country's national curriculum. ${ }^{5}$ The SLTRC was one of the two TJ mechanisms established in Sierra Leone in 2002 following the signing of the peace agreement by the warring parties, notably the government and the Revolutionary United Front (RUF). The other mechanism was the Special Court of Sierra Leone (SCSL). The SLTRC mandate, which expired in 2004, was "to create an impartial historical record of violations and abuses ..., to address impunity, to respond to the needs of the victims, to promote healing and reconciliation and to prevent a repetition" of the atrocities through truth-telling. ${ }^{6}$ The secondary-school resource that emerged from the work of the SLTRC was written by two Sierra Leoneans with the assistance of an international media consultant from Germany and the financial support of the German Foreign Office. Its conceptualization also involved

3 Mohamed Sheriff and Elvira M. J. Bobson-Kamara, TRC Report: A Senior Secondary School Version (Sierra Leone: Truth and Reconciliation Working Group, 2005).

4 Lansana Gberie, A Dirty War in West Africa: The RUF and the Destruction of Sierra Leone (Bloomington: Indiana University Press, 2005); David Keen, "Greedy Elites, Dwindling Resources, Alienated Youths: The Anatomy of Protracted Violence in Sierra Leone," International Politics and Society 2 (2003): 67-94.

5 Sierra Leone Truth and Reconciliation Commission, Witness to Truth: Report of the Sierra Leone Truth and Reconciliation Commission, Volume 2 (Freetown: SLTRC, 2004), 204. See also Julia Paulson, "The Educational Recommendations of Truth and Reconciliation Commissions: Potential and Practice in Sierra Leone," Research in Comparative and International Education 1, no. 4 (2006): 338. Another outreach document worth mentioning here is the Child-Friendly Version of the TRC final report, which was produced by the TRC in cooperation with the UN and local children groups for primary schools: Sierra Leone Truth and Reconciliation Commission, Truth and Reconciliation Commission Report for the Children of Sierra Leone: ChildFriendly Version (Freetown: UNICEF, 2004).

6 Kirsten Ainley, Rebekka Friedman and Chris Mahony, eds., Evaluating Transitional Justice: Accountability and Peacebuilding in Post-Conflict Sierra Leone (London: Palgrave Macmillan, 2015). It is relevant to note that the Special Court did not develop documents specifically for children, although its two key outreach documents, The Court Made Simple and International Humanitarian Law Made Simple, were reportedly used in reaching out to young people as well. Maya Karwande, "Implementing an Engagement Model: Outreach at the Special Court for Sierra Leone," in Transitional Justice, edited by Clara Ramírez-Barat, 49-96. 
teachers and pupils. "[E]xpected to be taught in class," this outreach document was officially endorsed by the national Ministry of Education and by the SLTRC.

The second initiative investigated in this study is 100 Days in the Land of the Thousand Hills, a 55-page document produced by the Tanzania-based UN International Criminal Tribunal for Rwanda (ICTR) in 2011. ${ }^{8}$ The book was republished in 2014, twenty years after the state-sponsored genocide of 1994, which killed nearly 1 million Rwandans, primarily of the Tutsi minority, and displaced over 2 million in the context of a four-year civil war between the then Hutu majority government and the eventually victorious Tutsi rebel movement of the Rwandan Patriotic Front (RPF). Established by the UN in November 1994 and operating until December 2015, the ICTR was mandated with "bringing to justice those responsible for serious violations of international humanitarian law" committed in Rwanda throughout 1994, and thereby "contribut[ing] to the process of national reconciliation and to the restoration and maintenance of peace." The document was written by the Senegalese ICTR Communication and Outreach Unit's spokesperson and was funded by the German embassy in Tanzania.

These TJ outreach materials are unique in at least two ways. First, they are resources designed to inform younger generations as much about transitional justice as about the violent past. Alongside the familiar objective of raising public awareness and active stakeholdership, their aim is to teach about and encourage understanding of a troubling recent history of violence while fostering a culture of peace and human rights. Second, the materials examined in this study fall into the genre of the graphic novel or comic, thus representing an instance of the innovative use of creative approaches combining images and text to teach about violent pasts and efforts to deal with their legacy. ${ }^{10}$ The genre's use as a vehicle for the representation of collective violence, while highly contentious, has been

7 John Caulker, "Foreword," in Sheriff and Bobson-Kamara, TRC Report, 4.

8 Bocar Sy, 100 Days in the Land of the Thousand Hills (Arusha: ICTR, 2014) [first published in 2011]. Another comic book on the Rwanda genocide designed for children and by the same author is Tugire Ubumwe - Let's Unite! published by the UN Outreach Programme on the Rwanda Genocide.

9 Philip Clark and Zachary Kaufman, After Genocide: Transitional Justice, Post-Conflict Reconstruction, and Reconciliation in Rwanda and Beyond (Columbia/Hurst: Columbia University Press, 2009); Gerald Gahima, Transitional Justice in Rwanda: Accountability for Atrocity (New York: Routledge, 2013).

10 In the context of this chapter, the terms "graphic novel" and "comic book" are used interchangeably to refer to a literary genre and cultural art form characterized by "juxtaposed pictorial and other images in deliberate sequence." Scott McLoud, Understanding Comics: The Invisible Art (New York: Kitchen Sink Press, 1993), 9. For scholarly discussions on the genre of graphic novels, see also Jan Baetens and Hugo Frey, The Graphic Novel: An Introduction (New York: Cambridge University Press, 2014); and Hugo Frey and Benjamin Noys eds., History in the Graphic Novel, special issue, Rethinking History 6, no. 3 (2002). 
gaining in legitimacy and popularity. ${ }^{11}$ One view regards the use of comics as a powerful strategy for representing and making accessible complex issues when "words alone have proven curiously inadequate."12 Critics of the approach, meanwhile, have pointed to the inappropriateness of using comics for this purpose, expressing concerns around the potential for trivializing tragic and traumatic experiences and for overly simplistic and inaccurate depictions reducing complex historical dynamics into frozen moments. Despite this contention, comics and graphic novels are increasingly finding their way into schools around the world as tools for teaching about such violent events as the Second World War and the Holocaust, prompting new research to investigate their use in the classroom. ${ }^{13}$

With its focus on primarily retrospective TJ outreach materials, this chapter draws on debates around postwar opportunities and challenges associated with teaching violent pasts to young people, a group constituting the bulk of today's Sierra Leoneans and Rwandans. A range of theoretical and empirical studies have outlined the importance of educating younger generations about painful pasts for the sake of a better future while recognizing the daunting nature of such endeavours. ${ }^{14}$ This research proceeds from the premise that, assuming that histories of war and mass violence are integral parts of young people's education toward informed citizenship, those designing educational media to address these issues face multiple dilemmas regarding how to represent traumatic events. Prominent among these is the tension between fidelity to the brutality and

11 Numerous compelling graphic novels exist today covering instances of war and mass violence. Among the most well-known are: Joe Kubert, Fax from Sarajevo: A Story of Survival (Milwaukie, OR: Dark Horse Comics, 1996); Joe Sacco, Safe Area Gorazde: The War in Eastern Bosnia, 1992-1995 (Seattle, WA: Fantagraphic Books, 2000), and Palestine (Seattle, WA: Fantagraphic Books, 2001); Art Spiegelman, Maus, A Survivor's Tale I: My Father Bleeds History (New York: Pantheon Books, 1986), and Maus, A Survivor's Tale II: And Here My Troubles Began (New York: Pantheon Books, 1991).

12 Michiko Kakutani, quoted in Michael Cromer and Penney Clark, "Getting Graphic with the Past: Graphic Novels and the Teaching of History," Theory and Research in Social Education 35, no. 4 (2007): 584.

13 Lila L. Christensen, "Graphic Global Conflict: Graphic Novels in the High School Social Studies Classroom," The Social Studies 97, no. 6 (2006):227-230; Cromer and Clark, "Getting Graphic with the Past", 574-591. On the use of this genre in school settings, see also the recent work by William G. Brozo, Gary Moorman and Carla Meyer, eds., Wham! Teaching with Graphic Novels Across the Curriculum (New York: Teachers College Press, 2014), and Carrye Kay Syma and Robert G. Weiner, eds., Graphic Novels and Comics in the Classroom: Essays on the Educational Power of Sequential Art (Jefferson, NC: McFarland, 2013).

14 Denise Bentrovato, Karina V. Korostelina and Martina Schulze, eds., History Can Bite: History Education in Divided and Postwar Societies (Göttingen: V\&R unipress, 2016); Elizabeth A. Cole, ed., Teaching the Violent Past: History Education and Reconciliation (Lanham, MD: Rowman \& Littlefield, 2007); Julia Paulson, “'Whether and How?' History Education about Recent and Ongoing Conflict: A Review of Research," Journal on Education in Emergencies 1, no. 1 (2015): 14-47. 
complexity of violent experiences and appropriate depiction of such events for target audiences consisting primarily of children and adolescents, many of whom have been directly or indirectly affected by the recent violence. The critical political, ethical, pedagogical and aesthetic choices involved in developing such materials will frequently entail negotiation between conflicting demands and needs.

Drawing on a content analysis of the TJ outreach materials and their reception by target audiences in Sierra Leone and Rwanda respectively, this chapter investigates the strategies they adopt for teaching young people about histories of war and violence. It assesses the value of such materials as pedagogical tools for promoting a historical understanding of past violence and furthering the cause of peace and reconciliation, and concludes by reflecting on some of the lessons learned regarding the promises and pitfalls of these initiatives while also underscoring the need for more empirical research on their reception and impact. Its reflections seek to offer valuable insights that will contribute to ongoing efforts in the assessment of transitional justice processes and related postwar educational interventions in and beyond Rwanda and Sierra Leone.

\section{Methodology}

This study employs an interdisciplinary and multi-method approach. Its first part examines similarities and differences between the strategies and techniques of representation employed by the two sets of TJ outreach materials as they negotiate dilemmas and contrasting demands related to the highly sensitive and controversial histories they depict. ${ }^{15}$ Taking inspiration from theoretical and methodological perspectives from literary and cultural studies, the research draws on qualitative content analysis, particularly textual and pictorial analysis, to decipher the narrative and visual rhetoric characterizing the two cultural artifacts, examining and comparing emerging themes, perspectives and stylistic choices. ${ }^{16}$ It deconstructs these texts through discourse analysis, highlighting emphases, omissions and interpretations in order to discern bias in the use of language and images to pursue particular purposes in specific contexts. Moving beyond a critical examination of the materials' content, the study seeks to

15 While valuable, an additional analysis of the processes involved in the conceptualization and development of the materials at hand is beyond the scope of this chapter. Unfortunately, in both cases, the retrieval of substantial information and insider views about such processes proved impractical during field research.

16 Chris Barker, Cultural Studies: Theory and Practice, 4th Edition (London/Thousand Oaks: SAGE, 2011); Robert Dale Parker, ed., Critical Theory: A Reader for Literary and Cultural Studies (New York: Oxford University Press, 2012). 
evaluate the strategies chosen to navigate dilemmas related to teaching young people about extreme violence committed in the course of recent conflict while recognizing that there are no universal and one-fits-all formulas and that attempts to develop benchmarks in this regard remain elusive. In an effort to identify criteria against which to evaluate such strategies, this study complements the analysis described above by drawing on the wealth of literature about Holocaust education. One characteristic of educational materials deemed particularly desirable in the treatment of violent histories is the capacity to promote an appreciation of the complexities of the topic through attention to such aspects as factual accuracy, historical contextualization, multiperspectivity, humanization and individuation through engagement with the lives and agency of people who lived through past violence, and reflection on the legacies of these experiences. Conversely, concerning factors may include simplification, the use of excessively graphic accounts and portrayals of violence, and the presentation of victims as passive and anonymous masses. ${ }^{17}$

The second part of the work underpinning this chapter complements the content analysis by investigating grassroots perspectives of those directly targeted by these TJ educational interventions. Specifically, it presents the results of a small-scale exploratory study seeking insights into teacher and student awareness, and attitudes and perceptions regarding the materials under scrutiny in the two countries. Drawing on evaluation research, ${ }^{18}$ the study thus seeks to assess the perceived relevance and effectiveness of these educational materials in addressing postwar needs and priorities, alongside their impact and sustainability. It reports on qualitative fieldwork conducted in Sierra Leone's capital, Freetown, in 2007 and 2011 and, more recently, in Rwanda's capital, Kigali, in $2015 .{ }^{19}$ In each country, four focus group discussions (FGDs), each composed of 6 respondents, were carried out with a non-representative convenience sample of a total of 12 qualified and trainee teachers and 12 secondary-school pupils and school graduates aged 17 to 25 . Altogether, 24 respondents were thus involved in each country, with a total of 48 teachers and students participating in the discussions. All respondents were randomly approached at schools or in the community and invited to volunteer for the research project. FGDs were con-

17 See, among others, the educational guidelines developed by the International Holocaust Remembrance Alliance (IHRA), "IHRA Resources Guide," https://www.holocaustremem brance.com/educate/teaching-guidelines, accessed 9 March 2016. For a comprehensive collection of recent research on Holocaust education, see Zehavit Gross and E. Doyle Stevick, eds., As the Witnesses Fall Silent: 21st Century Holocaust Education in Curriculum Policy and Practice (Cham: Springer, 2015).

18 Michael Quinn Patton, Qualitative Research \& Evaluation Methods: Integrating Theory and Practice, $4^{\text {th }}$ edition (London/Thousand Oaks: SAGE Publications, 2014).

19 Fieldwork was conducted within the framework of two larger research projects on education and peacebuilding in West and Central Africa. 
ducted in English by the author using a standardized questionnaire with openended questions. Questions for teachers primarily sought to establish whether the TJ materials were known and used in the classroom and, if so, how and for what purpose. Fieldwork with pupils was aimed at investigating the degree to which their exposure to the materials prompted engagement with the past. Questions were formulated with the objective of prompting the young respondents to critically reflect upon their understanding of the book's content and meaning, its objectivity and comprehensiveness, the messages and lessons they took away from the reading, the emotional responses elicited, and, ultimately, their perceptions of the materials' significance for contemporary society. ${ }^{20}$

The following sections take a closer look at the stated aims and content of the two sets of TJ outreach materials in postwar Sierra Leone and Rwanda respectively before turning to the empirical findings emerging from the fieldwork.

\section{Sierra Leone's TRC Report. A Senior Secondary School Version}

In Sierra Leone, the TRC Report. A Senior Secondary School Version aims to teach secondary-school students aged 15 to 19 about the work of the TRC and the history of the country's recent war and its aftermath. Its stated objective is to promote human rights education in a society where war resulted in a "lost generation" of young people and where the need "to respond to the challenges created by misguided youths in the past and ... to restore youths as productive members of their communities" has remained salient. ${ }^{21}$

The book echoes the structure and themes of the three-volume long final report of the TRC in its original version. It includes eight chapters outlining the historical antecedents and causes of the conflict and offering a factual and detailed account of the course and nature of the war. ${ }^{22}$ In so doing, it pays considerable attention to the types of violations committed and, in line with the final report, identifies both victims and perpetrators, the latter with their share of responsibility, without naming individuals. ${ }^{23}$ Like the original report, the school

20 In Rwanda, where none of the young respondents was found to know the resource under investigation, the reading was assigned to each respondent individually and discussed in focus groups the following week.

21 Sheriff and Bobson-Kamara, TRC Report, 102.

22 The text traces the origins of the conflict to bad governance and abuse of power, manifest in the suppression of political dissent and "endemic greed, corruption and nepotism." Ibid., 35.

23 It mentions, in this specific order, the Revolutionary United Front of Sierra Leone (RUF), the Armed Forces Revolutionary Council (AFRC), the Civil Defence Forces/Kamajors (CDF), the Government of Sierra Leone (SLA) and local civil forces, and foreign troops. 
version places particular emphasis on the experiences of women, children, and young people, three groups identified as "the most vulnerable and the worst hit." 24 The separate chapters dedicated to each of these groups outline their multifarious roles during the war. The book, for instance, points out that some women "committed human rights violations in the same way as men in their positions did," while others chose to act as peacemakers. It also highlights the dual role of forcibly recruited children as victims and perpetrators, thus thematizing the complexity of the ordeal undergone by young people "transformed into killing machines." ${ }^{25}$ The book further recognizes the enduring impact of the conflict on these groups and the present-day challenges they face.

This narrative of the conflict is placed between an introduction to the TRC, detailing its origins, aims, proceedings, and achievements, and a forwardlooking chapter titled "Reconciling the Past and Looking to the Future," which deals with issues related to reconciliation and the broader TJ framework. The text provides legitimation for the establishment of the TRC as an effective way of responding to the stated imperative of facing history through truth-telling in order to "build a new Sierra Leone." 26 The book teaches young Sierra Leoneans that "[w] need to confront the past" 27 in order to know "what went wrong" and "why ... so many abandon[ed] traditions of community and peaceful coexistence", ${ }^{28}$ arguing that "[w]e must know and understand, then it won't happen again." ${ }^{29}$ Like the original report, the educational material valorizes remembering and truth-telling, echoing messages communicated in TRC leaflets and posters such as "Truth today! Peaceful Sierra Leone tomorrow." 30

Measures to render the book more comprehensible for its young readers included condensing the original text from 2,000 to 127 pages, simplifying its language and adding a glossary in an appendix. Additionally, each of the eight chapters features a fictional cartoon story illustrating the topic under discussion. ${ }^{31}$ The book further provides a series of suggested activities, including role-plays, discussions, writing exercises and artistic tasks, encouraging students to critically engage with the content of the book and talk about selected matters in the classroom.

A striking characteristic of the cartoons included in this resource is their

24 Ibid., 75.

25 Ibid., 108.

26 Ibid., 15.

27 Ibid., 8.

28 Ibid., 13.

29 Ibid., 9.

30 Rosalind Shaw, Rethinking Truth and Reconciliation Commissions: Lessons from Sierra Leone (Washington DC: USIP, 2005), 8.

31 This story was also represented on posters that were displayed in schools and used in communities by storytellers. 
metaphorical use of anthropomorphic animal characters, namely mice and cats, the latter representing "the evil ones." 32 The authors justify the use of animal imagery as a strategy for the depiction of Sierra Leone's sensitive history in a "less painful," more depersonalized and less stigmatizing manner, "without referring or seeming to refer to individual persons," 33 and for encouraging young people to engage with the past. ${ }^{34}$ The cartoon tells "the story of Sierrarat" - "our story." Its opening scene recounts that "Sierrarat was once a poor but peaceful and beautiful country ... until one day in March 1991," when it was attacked by Sierrarat people turned into cats. ${ }^{35}$ The principal vehicle via which the cartoon conveys the essence of the TRC's findings is the traumatic personal story of the mouse Ratabu and his family. This fictional story runs through the book's various chapters, graphically rendering the ordeal of individuals and their families during the war. It recounts the displacement and abduction of this family, the beatings and amputations that Ratabu suffered after resisting a commander's decision to take his 12-year-old daughter as a bush wife, the murder and disembowelment of Ratabu's pregnant wife, and the forcible conscription of his sons, "taught and made to kill."36 It then describes the death of one son and the survival of the other who, after the war, lived as a street child, and about the reunion of Ratabu and his daughter, who returned home after overcoming the fear and shame of having conceived children by her abductor and abuser. The cartoon's final image conveys a positive and hopeful ending, emphasizing the concepts of peace, unity, reconciliation, repentance, forgiveness, and progress. Other concepts, most notably justice, do not have a place in this context, evidencing attempts in the material to legitimize the TRC and the authors' nor-

32 Sheriff and Bobson-Kamara, TRC Report, 44. This book's use of animal characters is reminiscent of the ground-breaking German Holocaust graphic novel Maus, in which Spiegelman illustrates Jews as mice and Nazis as cats. The extent to which this represents a case of cultural transfer and the level of influence exercised by German consultants and funders on the eventual format of the project are questions that this naturally raises. While this question could not be investigated in the framework of this study as no interviews were conducted with those involved in the production of this material, Zoe Dugal found that, whereas reactions to this proposed design were ones of hesitancy among the international staff of the TRC, "as rats in Western cultures are seen as disease spreading animals," Sierra Leonean staff members in contrast were favorable to the idea as they perceived rats as "friendly cartoon characters to reach out to youth." Zoe Dugal, "Outreach to Children in Transitional Justice Processes in Sierra Leone," in Transitional Justice and Education: Learning Peace, edited by Clara Ramírez Barat and Roger Duthie (New York: SSRC, 2016).

33 Caulker, "Foreword," 4.

34 Ibid.

35 Sheriff and Bobson-Kamara, TRC Report, 5.

36 Ibid., 109-110. 
mative position vis-a-vis the "truth-versus-justice" debate within the TJ literature. $^{37}$

It is notable that, while the book employs a fictional cartoon story to teach about the war's "shocking brutality" in a "less painful" way, it does not shy away from graphic images of violence. The book includes images showing the results of violent actions such as amputation, presented in one panel depicting blood flooding from Ratabu's severed arms, and disembowelment, portrayed through the scene of the dead foetus of Ratabu's pregnant wife being triumphantly held up by her tormentor. ${ }^{38}$ The sense of horror graphically portrayed in the cartoon panels appears compounded in the text by the use of explicit and often profoundly disturbing testimonies of "harrowing" 39 experiences as recounted by victims and perpetrators, including children, to the TRC during its investigation. One such testimony, from a mother, describes: "They cut my son in pieces alive ... they took out his heart and cut a piece of it and pushed it into my mouth ... then when they have cut his head, they laid it in my hand saying go and breast feed your son and they started dancing." ${ }^{\prime 40}$ Another is from a man who witnessed how " $[\mathrm{t}]$ hey ... took a sharpened stick and jabbed [two pregnant women] inside their wombs until the babies came out on the stick." ${ }^{41}$ Yet another spoke of a "commander ... put[ting] the gun in his [a man's] mouth ... [h] is brains scattered all over the street." 42

A further troubling aspect in this regard is the book's inclusion of exercises in historical empathy and perspective-taking, some of which are confrontational and presumably extremely challenging in a context in which, as recognized by the book, "[m] ost of you must have had some experience of the war, either first hand or by hearing it from friends and relatives." ${ }^{\text {"3 }}$ Among these are role-plays of statement-taking and public hearings at the TRC, in which students are asked to imagine and enact being a witness, a victim and/or a perpetrator, and to give "real or imaginary accounts of their war experiences,"44 "describing what you saw and how you felt." 45 Whereas this particular exercise gives students the

37 See, for instance, Robert I. Rotberg and Dennis Thompson, Truth Versus Justice: The Morality of Truth Commissions (Princeton, NJ: Princeton University Press, 2000). For a critique of this dichotomous debate, see Naomi Roht-Arriaza and Javier Mariezcurrena, eds., Transitional Justice in the Twenty-First Century: Beyond Truth versus Justice (Cambridge: Cambridge University Press, 2006).

38 Sheriff and Bobson-Kamara, TRC Report, 65, 83.

39 Ibid., 91.

40 Ibid., 59.

41 Ibid., 80.

42 Ibid., 71.

43 Ibid., 17.

44 Ibid.

45 Ibid., 57. 
option to relate imagined experiences, another explicitly asks students to "[s]hare some frightening experiences you had during the war with the rest of the class" and to answer questions "about how you felt during those experiences and how you coped." It further encourages students to talk to their family members about their experiences and coping strategies. ${ }^{46}$ Once again in line with the values and norms underlying the work of the TRC, the book thus encourages "public recounting of memories of violence," a practice valorized by the TRC as having therapeutic and reconciliatory value. ${ }^{47}$

\section{Rwanda's ICTR Comic Book, 100 Days in the Land of the Thousand Hills}

In Rwanda, the ICTR comic book 100 Days in the Land of the Thousand Hills, aimed at children of eight years and above, seeks to "facilitate the understanding of young people in the region about the Rwandan genocide" as part of a mission "to ensure ... that the concept of 'Never Again' becomes a reality" and that younger generations will be inspired "to act responsibly in their societies."

Similarly to the SLTRC material, the ICTR comic book draws on fictional personal stories in order to render the historical episodes of war and mass violence more comprehensible for young people. At its core is the tragic story of two 10-year-old schoolchildren, Kagabo and Francoise, a Tutsi and a "moderate Hutu" respectively, neighbors and best friends, both orphaned in $1994 .{ }^{49}$ The cartoon tells of the two children's dangerous journey to escape and hide from certain death as the situation in the country quickly escalates from targeted discrimination, dehumanization and harassment to outright massacres of Tutsi and of "moderate Hutu" seen as Tutsi accomplices. Their story, used as a medium to communicate the hardship, fear and desperation experienced by the victims of the genocide, is intertwined with a broader national narrative touching upon cases investigated by the tribunal and incorporating several key events that marked the history of the genocide, including some of the most notorious massacres and most celebrated acts of organized resistance. ${ }^{50}$ A glossary explains

46 Ibid., 101.

47 Shaw, Rethinking Truth and Reconciliation Commissions, 2.

48 Bongani Majola, "Welcoming note," in Sy, 100 Days, 4. For a critical analysis of this cartoon's content, see also Deborah Mayersen, "One Hundred Days of Horror: Portraying Genocide in Rwanda," Rethinking History: The Journal of Theory and Practice 19, no. 3 (2015): 357-369.

49 Sy, 100 Days, 7.

50 Among other things, the book refers to the massacre at Murambi technical school in Gikongoro, at Butare hospital and at Nyange parish, as well as to the Tutsi heroic resistance in Bisesero. 
key characters, localities and events referred to in the book. Unlike the SLTRC material, the book includes neither authorial text for informative purposes nor learning activities.

A critical analysis of the book's content against its stated aims shows it to be more articulate in outlining "the dynamics and evils of genocide" than it is in explaining its origins and causes. While the SLTRC material relies on the authorial text accompanying the cartoon to explain the causes of civil war in Sierra Leone, the ICTR resource, lacking any type of informative section, falls short of providing historical depth and contextualization. Some of its statements and images are particularly misleading in their portrayal of a sense of abrupt change and disruption of a romanticized pre-genocide past. Not dissimilarly from the SLTRC material in Sierra Leone, the ICTR cartoon's story begins by portraying Rwanda as once "a harbor of peace" and "a wonderful country," where "[e]verything was always quiet and beautiful" until "[o]ne morning in April, something terrible happens to the Land of a Thousand Hills." ${ }^{\text {"1 }}$ Serene images of peaceful and pristine landscapes are abruptly juxtaposed with images of destruction, with little or no explanation. An impression of sudden change also emerges in a panel showing a teacher writing "We are all Rwandese" on a classroom blackboard in April 1994, followed by a panel illustrating how "One day [emphasis added], the teacher separates the Hutu children from the Tutsi and canes the Tutsi children for no apparent reason." ${ }^{52}$ The cartoon is silent with regard to the longstanding history of practices of discrimination and violence that preceded the 1994 genocide, with only two references throughout the text to previous killings of Tutsi, notably in the late 1950s.

The thorough representation of the "dynamics and evils of genocide" is not without its issues. This said, and in stark contrast to the rather crude SLTRC material, the narrative and graphical strategies of the ICTR book appear more sensitive to the need to convey the horror of the violence without disturbing young readers' sensitivities with excessively graphic depictions. The book avoids visually explicit representations of acts of violence, instead creating a sense of implied violence through panels suggesting that abuse might or will ensue. Images portray armed men threatening, for example, killings that are later confirmed. Images of bloodstained walls and of burning and bulldozed buildings and hideouts, which in previous panels were crowded with people looking for a safe haven, likewise imply atrocities. ${ }^{53}$ What happened in the space between the frames is left to the reader's imagination. Other techniques used in the material to portray the violence with caution are visual distancing and minimalism:

51 Ibid., 7.

52 Ibid., 10-11.

53 Ibid., 32, 36-37. 
victims of mass killings appear as small and out of focus, floating in a river, tossed in mass graves, or littered in valleys as survivors watch "helplessly" from the surrounding hills. ${ }^{54}$ For the most part, the book makes similarly sensitive use of language. The narrative omits lurid descriptions of the violence, with the notable exception of a caption explaining that "babies were smashed against the walls." 55 While thus creating a degree of distance from the violence, the book encourages empathy toward the victims, reinforced through the abundant use of expressive close-ups capturing their sense of despair. At the same time, the cartoon employs a strategy of "othering" and distancing toward the perpetrators, depicting them as possessing almost demonic demeanours and as indulging and delighting in moral depravity, with images showing killers "dancing and drinking in celebration" and "excit[ed] because of the cries of the babies and their mothers" as they were being burned alive. ${ }^{56}$ The book thus appears to forestall critical engagement with what is depicted as "evil" by failing to address the complex processes through which ordinary people become willing executioners in genocidal contexts. ${ }^{57}$

In describing the "dynamics and evils of genocide," the cartoon extensively addresses the issues of responsibility and accountability which are key to the work of the ICTR. The book delineates key roles and responsibilities in the violence, implicating a large spectrum of actors and institutions found guilty by the tribunal after legal investigation and prosecution. These include members of the interim government, local authorities, army soldiers and associated militias (commonly known as "Interahamwe"), the media, and religious leaders. Like the SLTRC book, the ICTR material refrains from naming names, while implicitly referring to public figures who were sentenced by the tribunal for their key roles in the cases it investigated. ${ }^{58}$ The book also recognizes the widespread complicity of "Hutu civilians," shown cheering and supporting the militias, harassing the victims, and looting and destroying their properties. ${ }^{59}$ While at times simplistic, the cartoons provide opportunities for the reader to reflect upon complex issues

54 Ibid., 28, 22, 44.

55 Ibid., 43.

56 Ibid., 31 .

57 On the complexities of these dynamics, see James Waller, Becoming Evil: How Ordinary People Commit Genocide and Mass Atrocity (New York: Oxford University Press, 2002).

58 The comic book implicitly refers, for example, to Hassan Ngeze, referred to as "an extremist Hutu journalist" at the head of the hate-mongering Kangura magazine; Georges Ruggiu, "a white journalist" airing on the infamous radio station RTLM (28) and "the only nonRwandese man to have sided with the Hutus" (7); Simon Bikindi, "a very well known musician" in propagating hate messages through his songs on the radio (13); interim Prime Minister Jean Kambanda; and Father Athanase Seromba, former Catholic priest at Nyange parish in Kibuye, where many were killed under his supervision.

59 Sy, 100 Days, 21, 40. 
such as coerced participation, with some characters forced to take part in the violence in order to save themselves and their loved ones, and the ambiguity of perpetrator-rescuers, manifest in one scene where a local leader secretly helps the protagonists flee after convincing a threatening mob that he would "take care" of them personally. ${ }^{60}$ Further, the book convincingly conveys the grave risks associated with resisting the state genocidal plan and assisting the Tutsi, with Hutu upstanders, considered "traitors," being condemned to the same fate.

The ICTR book's treatment of the role played by the now-ruling RPF during the conflict raises particular concerns. The narrative depicts the RPF as fighting against the genocidal forces, establishing safe zones and providing assistance to the refugees before eventually succeeding in "chas[ing] out the extremist government and their army." ${ }^{\prime 61}$ In the process of narrating the former rebels' military advancement and victory, the book evades discussion of the crimes reportedly committed by RPF soldiers during military operations in Rwanda and in the neighboring Democratic Republic of Congo, a country which had become a safe haven for hundreds of thousands of génocidaires and innocent Hutu civilians. This omission reflects the ICTR's failure to investigate alleged crimes by the RPF despite its mandate to do so, be it for political or practical reasons related to the need to secure Rwanda's cooperation with the tribunal. ${ }^{62}$ The book remains conspicuously ambiguous regarding highly controversial discussions on the RPF's degree of responsibility for the violence, possibly a manifestation of a difficult relationship with the RPF. There is an apparent hint at the RPF's onus of responsibility when the publication seemingly traces the beginning of harassment and discrimination against the Tutsi to the moment when the RPF "invaded" Rwanda, ${ }^{63}$ describing with a notably negative term what Rwanda's dominant discourse celebrates as a "liberation war." It thus fails, in a further demonstration of poor historical insight, both to discuss the longstanding harassment of Tutsi commencing at the end of the 1950s and to contextualize and explain the antecedents and origins of the Tutsi refugees' military actions against the backdrop of their decades-long forced exile after successive waves of targeted

60 Ibid., 24, 33-34.

61 Ibid., 51.

62 On accusations and defensive postures towards the ICTR's alleged dispensation of a "victor's justice," see Victor Peskin, International Justice in Rwanda and the Balkans: Virtual Trials and the Struggle for State Cooperation (New York: Cambridge University Press, 2009), and Lars Waldorf, “'A Mere Pretense of Justice': Complementarity, Sham Trials, and Victor's Justice at the Rwanda Tribunal," Fordham International Law Journal 33, no. 4 (2010): 1221-1277. See also Charles Chernor Jalloh and Andrew Morgan, "International Criminal Justice Processes in Rwanda and Sierra Leone: Lessons for Liberia," in Shielding Humanity: Essays in International Law in Honour of Judge Abdul G. Koroma, edited by Charles Chernor Jalloh and Olufemi Elias (Leiden/Boston: Brill Nijhoff, 2015), 447-509.

63 Sy, 100 Days, 11. 
violence. Additionally, the book remains ambiguous on the controversial issue of accountability for the still unresolved plane crash that killed both Rwanda's and Burundi's presidents, sparking the genocide in April 1994. As part of the events' contextualization, the book reports allegations leveled at the time against the RPF by media inciting and fueling the genocide, yet it neither discusses, confirms nor dismisses them, leaving the reader to trust their validity. ${ }^{64}$ The material seems to further hint at the RPF's burden of responsibility for the violence by controversially suggesting that the purpose of its military actions was to "take over" Rwanda at all costs. Its authors comment that "[a]lthough the RPF has been able to take over the country, it is at a high price." ${ }^{25}$

The book is also strikingly evasive with regard to the controversial role of the international community and the UN in the genocide, notably its inaction and bystander attitude. This evasion corresponds to the ICTR's one-sided investigative focus on local actors - and these only "on one side of the conflict" reflects its neglect of foreign actors' roles in the violent events. The book predominantly conveys the vain resolve, courage, defiance, and self-sacrifice of UN troops in their efforts to protect those targeted. It includes images of UN soldiers pleading for safe passage at roadblocks in order to fulfill their mandate, and the sacrifice of Belgian peacekeepers who were tortured and killed by génocidaires while on duty. A sense of failure and powerlessness is detectable in panels depicting the case of the UN-protected Ecole Technique Officielle (ETO), where many refugees had sought sanctuary, "believ[ing] they [were] going to be safe." The cartoon shows UN vehicles leaving the area surrounding the school to the mercy of armed militiamen and explains that a massacre occurred there "[i]mmediately after the departure of the Belgians," yet had previously emphasized that "[e]very day, the U.N. soldiers and the militia around the area quarrel[ed] over the fate of the refugees." ${ }^{67}$ Remarkably, the sudden withdrawal of UN soldiers from Rwanda remains fully unexplained in the cartoon: there is no mention of the relevant UN Security Council decision, made by the same organ that established the ICTR. Following the image of its withdrawal, the UN only reappears on the scene in the cartoon's concluding two-page spread portraying a group of children visiting the ICTR and learning about the tribunal's role in pursuing justice through trials of prominent génocidaires. Significantly, the story ends with the point that " $[t]$ here can be no peace without some form of justice for the victims of the genocide in Rwanda." ${ }^{\text {68 }}$ The ICTR, then, appears to

64 Ibid., 14-15.

65 Ibid., 51.

66 Klaus Bachmann and Aleksandar Fatić, The UN International Criminal Tribunals: Transition Without Justice (London/New York: Routledge, 2015), 42.

67 Sy, 100 Days, 19-20.

68 Ibid., 52-53. 
self-legitimize here as the means for the fulfillment of this purpose, omitting to mention the many local initiatives promoting justice and reconciliation that have been launched within Rwanda itself. This selective and normative narrative points to the fine line between education and self-publicity running through such outreach materials and potentially problematizing their meaningful use in the classroom.

\section{Responses to the outreach materials}

The content analysis of the two resources discussed here has illuminated a number of aspects in which their approaches to addressing painful histories are comparable, albeit marked by various differences in their origins, format and graphical strategies. Both publications were conceived as having the significant potential to help prevent future violence by transmitting the truth to younger generations as uncovered by investigative processes linked to transitional justice mechanisms. In both cases this "truth," while highly normative in suggesting appropriate paths out of violence, is grounded in fact, despite the inevitable occurrence of simplification, silence and omission. These publications' illustration of the obscene realities of war and its devastating consequences engages young readers with complex, morally and emotionally charged themes intended to deeply move their audiences, drawing them into the narrative, warning and inspiring them. Themes include flight and displacement; courage and resilience; resistance, defiance, and sacrifice; suffering, death, loss, and trauma; shame, guilt, and responsibility; and hope, survival, and the triumph of good over evil. Both books also convey a sense of nostalgia for a peaceful prewar past and communicate the challenges and responsibilities inherent in surviving and living in the postwar era. Framed within a normative narrative, the TJ mechanisms in each case appear as compelling answers to a society's need for closure. As such, these materials represent cultural tools that are not as politically or ideologically neutral as they may claim to be; essentially, they are public relations documents which unmistakably support an agenda aimed at sensitizing the population to a particular TJ institution's work and its relevance to contemporary society.

In order to facilitate young readers' navigation of such themes and frame a complex past in an accessible story, both sets of materials draw on valuable creative strategies, intertwining nonfictional historical events and fictional personal stories, and depicting them graphically. Both publications favor a multi-layered approach, effectively showing how national and personal histories intersect and thus promoting an understanding of the violent past on a human level. First-person narratives and direct speech, typical of the comic-book for- 
mat adopted in both instances, serve to encourage young people's engagement with characters symbolizing real people in the past. The powerful use of the "gutter," the space between the frames in comic books, to leave the most brutal and unspeakable violence to the imagination shows sensitivity toward the books' young audiences. In both cases, the recounting of personal narratives from the perspectives of innocent victims with whom the reader is encouraged to empathize combines with a strategy of "othering" and distancing, in line with the materials' underlying normative and moral messages, of "evil" perpetrators. Certain nuances and levels of complexity and ambiguity do feature in these works; notable examples are perpetrator-rescuers in Rwanda and child soldiers as victim-perpetrators in Sierra Leone. Nevertheless, the predominant framing appears to be an often simplistically polarized and Manichean characterization of victims and offenders, a polarization allegorically represented in the story of "Sierrarat" in the SLTRC book as a natural distinction between predators and prey.

Having highlighted some of the common features in the textual and graphical strategies employed by these materials to relate a sensitive past, this section presents and discusses some of the key empirical findings deriving from fieldwork aiming to evaluate these initiatives. The first factor explored in this context is the level of public awareness of and access to these resources. Although largescale representative research is needed prior to any generalization of these findings, fieldwork in both countries ascertained poor knowledge of the existence of these resources among young people. Although they are freely available online, the materials appear to suffer from narrow accessibility and therefore limited impact. Among those surveyed in Sierra Leone, very few remembered having seen the TRC material, while in Rwanda none of the respondents had heard of the ICTR comic book. In addition, none of those interviewed in either country reported ever having been exposed to these resources in the classroom. This finding suggests failures in the effective linking of TJ outreach activities, of which young people are the stated primary beneficiaries, to national school systems. It is unclear whether or not the two TJ mechanisms in this case ever actively attempted such engagement in education systems. What this research indicates is that both appear to have been unsuccessful in securing substantial follow-up in the education sector and in ensuring their outreach documents find approval, distribution and use in schools. This missed opportunity calls for consideration of closer cooperation and coordination with educational actors and institutions, including teachers, in order to facilitate a greater impact and sustainability for $\mathrm{TJ}$ measures following the end of their mandate.

The second aspect investigated during fieldwork, which may explain further why such materials have not found their way into schools, relates to levels of 
acceptance and appreciation of these resources on the part of their target audience, especially teachers. Overall, the fieldwork indicated general appreciation for the pedagogical decision to adopt graphic novels as tools for encouraging young people to engage with history. This particular format was considered a potentially welcome addition to more typical classroom resources, and especially to traditionally text-based history books. Perceived as a "different," "original," and "refreshing" mode of representation, the combination of storytelling and images was credited with the power to better capture young readers' attention and interest. The materials' contemporary relevance also drew appreciation, as did their perceived recognition of "the hardship that we've lived through" 69 and the opportunity they appeared to present for younger generations to learn about, as well as from, a crucial and still influential aspect of their heritage. The materials' representational choices, however, were not uncontested. In Sierra Leone, for instance, the use of cartoons with animal characters was controversial. While some teachers praised it as a cautious and sensitive way of addressing the difficult past, others feared it might create confusion and uncertainty in young users as to "what is real and what is not."70

Despite the general recognition of the potential value of this type of media as pedagogical tools, teachers in both Sierra Leone and Rwanda appeared hesitant to introduce these materials into the classroom, should they have access to them. In general, their reluctance derived from the intrinsically challenging nature of the topic addressed and the limitations on their confidence and professional preparation with regard to such sensitive and contentious subjects. Besides this shared concern, teachers in each country had different considerations, dependent on the specific context in which their work was embedded. In Rwanda, the existence of a pervasive state-enforced official memory of the genocide in society, which has entered Rwandan schools as a compulsory aspect of the national curriculum, appeared to greatly influence teachers' considerations. ${ }^{71}$ Against this backdrop, Rwandan teachers expressed great concern to permit only authoritative and legitimate accounts to enter the classroom, so that they might fulfill the unanimously recognised civic imperative of educating younger generations about the genocide. Generally unaware of the existence of the ICTR cartoon, they tended a priori to be suspicious of the material and to retreat to the safety of state-approved textbooks carefully screened by the authorities for inconsistencies with the official discourse. Fieldwork thus suggested that non-state

69 Teacher FGD1, Kigali, 28 April 2015.

70 Teacher FGD2, Freetown, 20 January 2011.

71 Denise Bentrovato, Narrating and Teaching the Nation: The Politics of Education in Pre-And Post-Genocide Rwanda (Göttingen: V\&R unipress, 2015) and Denise Bentrovato, "Whose Past, What Future? Teaching Contested Histories in Contemporary Rwanda and Burundi," in History Can Bite, edited by Bentrovato, Korostelina, and Schulze. 
actors and institutions such as the ICTR inevitably face a great challenge: the perceived exclusive and uncontested (indeed incontestable) authority of the state in the matter of knowledge production on this topic places significant obstacles in the way of alternative resources and the accounts they convey.

In Sierra Leone, the context influencing teacher attitudes is radically different. Greater discursive freedoms are permitted than in Rwanda; teachers were often aware of the TRC material and generally regarded the account it presents as factual and authoritative, albeit not uncontroversial. All teachers, however, declared their a priori preference for avoiding any such war-related resources, on the basis of the argument that talking about the war was still too difficult and painful and could endanger social cohesion. These attitudes reflect a pervasive societal amnesia and culture of silence surrounding the war in Sierra Leone, which appears institutionalized in the lack of official curricula, textbooks and teacher-training programs addressing the war and its legacy. ${ }^{72}$ Aligning themselves with a widespread forward-looking "forgive and forget" approach, the teachers commonly argued that, in order to create a responsible citizenry, it sufficed to teach younger generations about peaceful conflict resolution, human rights, and civic responsibilities without explicitly referring to their country's painful history. They also admitted that, on account of the numerous difficulties presently facing their country, teaching about the violent past and TJ issues was neither a political nor a societal priority. According to one teacher, "Sierra Leoneans, especially the youth, are not so much interested in the past or even in the future. They are interested in surviving in the present."73 FGDs with young Sierra Leoneans confirmed this view; their reflections on the past as prompted by the research were quickly overshadowed by discussions on present preoccupations, including the urgent need to tackle the rampant youth unemployment, poverty and inequality which deeply affected their daily lives. Rather than necessarily dismissing the relevance of this material altogether, this finding on the relative significance attributed to present conditions as opposed to past ordeals is suggestive of a source of potential added value for TJ educational materials. They may have the potential to help younger generations make sense of past violence by thinking about its legacy in the present and by exercising "historical thinking" to make more explicit connections between causes and consequences.

Further exchanges with young people during fieldwork provided additional insights into the grassroots reception and apparent impact of the educational materials at hand. Their responses to the question as to what they had learned

72 Mneesha Gellman, "Only Looking Forward: The Absence of National History in Sierra Leone," in History Can Bite, edited by Bentrovato, Korostelina, and Schulze.

73 Teacher FGD1, Freetown, 19 January 2011. 
from the books provide particularly acute insights into the extent to which these resources' narratives and imagery, in eliciting cognitive and emotional responses, aided young readers in grasping the complexities of a conflict closely experienced.

First, fieldwork seemed to suggest that the particular effectiveness of these resources lay in encouraging an empathic understanding of the victims' horrific experiences. The emotionally charged stories appeared to be powerful catalysts for affective engagement with the past, reminding readers of "how much people suffered in those days, especially young people like us." ${ }^{374}$ The emotional responses the texts elicited in young readers, as recorded during the fieldwork, reflected those palpably felt by the victim-protagonists, including fear, horror, despair, devastation, sorrow, helplessness, and urgency. Significantly, in expressing their sympathy, respondents in both countries avoided relating their personal experiences or those of their families. This indication of reticence in this regard raises questions around the suitability of confrontational learning activities such as those proposed in the SLTRC material, which encourage students to share their own experiences of violence. Contrasting with the potential of these resources to facilitate young people's understanding of the victims' plight, fieldwork uncovered a simultaneous failure to encourage adoption of the perpatrators' perspectives and thus a comprehension of the latter's thought processes and actions. These were typically dismissed as being beyond rational comprehension. Fieldwork in Rwanda in particular revealed the confirmation of Manichean views and dehumanized perceptions of the perpetrators on the part of the book's readers. These perceptions, thus reinforced, appeared to compound the respondents' difficulty in explaining and locating ambiguous roles of perpetrator-rescuers within a past world primarily understood as comprising separate groups of "good and wicked people."

Fieldwork provided further insights into the effectiveness of the educational resources with regard to facilitating young readers' understanding of the dynamics of the violent events within their broader historical context. The ICTR comic book limits its narrative to the events of 1994, overlooking their historical antecedents. Offering little, if any, historical and contextual explanation of the violence that befell Rwanda, it leaves its young readers to wonder "why did we come so far?" "why did so many participate in the violence?" and "how come nobody in the world cared enough to come and help us and stop the madness?"75 The TRC school material in Sierra Leone does a better job in this respect, locating discussions of human rights abuses experienced during the civil war within their larger historical context. This notwithstanding, its content seems overly con-

74 Youth FGD2, Kigali, 4 May 2015.

75 Youth FGD1-2, Kigali, 24 April 2015 and 4 May 2015. 
cerned with the horror of the war, a preoccupation - manifest in its grim images, accounts, and testimonies - which appears to have distracted some of its young readers from learning about and from their country's violent past. The questionable impact of this type of approach emerged during fieldwork, most notably from the finding that the very few respondents who had seen this book had retained little of it other than its drawings of mice and the long lists of violations reported. The book seemed to have primarily inspired aversion and disbelief toward the horrors of war portrayed. The readers remembered little or nothing about the causes and dynamics of the conflict, with most unable to explain what had happened in their country and why, and what might prevent it from happening again. The material does appear effective in its stated aim to teach young Sierra Leoneans that "war is a terrible thing and we must never let it happen again in our country."76 This said, the evidence regarding young people's retention of information from the material cautions against the use of exceedingly graphic content, indicating that it may not only provoke (re)traumatization, but also distract from learning rather than promoting it.

Field research further revealed the influence of contextual factors on the educative and transformative potential of such TJ measures. In line with findings from teacher FGDs, exchanges with young people in Rwanda in particular confirmed the crucial role of the present political context in impacting on the public reception and impact of any intervention. Exposed to the ICTR material, young people in Rwanda engaged in politicized readings of its content and in the concomitant rehearsal of a widely embraced master-narrative. Readers of the SLTRC resource largely accepted its content at face value and deemed it objective on account of its provenance as the result of a collective truth-seeking effort. Young Rwandans, by contrast, subjected the ICTR comic book to thorough scrutiny and judged it in terms of its level of compliance with the government's official discourse and its underpinning of norms and values to which the respondents appeared to strictly adhere.

While praised for effectively conveying the horror that had come upon the country in 1994 at the hands of the former regime and its accomplices, the ICTR resource was criticized for falling short of acknowledging the extent of the international community's implication in the genocide, instead offering a startlingly vague and sanitized image of its role. Echoing the hegemonic discourse in present-day Rwanda, the young readers affirmed that the comic book masked how "the Belgian colonizers and the French neo-colonizers [had] incited and facilitated the violence in the first place" and "how the world finally left Rwandans to die," which is why "those foreigners should face justice too."77 One

76 Sheriff and Bobson-Kamara, TRC Report, 75.

77 Youth FGD1, Kigali, 24 April 2015. 
student further questioned the veracity of the portrayal of UN soldiers arguing with militias at ETO to convince the génocidaires to spare Tutsi who had taken refuge there. Affirming that "we all knew how French troops were even playing volleyball there while people were [being] massacred and were crying for help," he concluded that "the UN is just trying to cover [up] the truth." ${ }^{78}$ Such comments raise the key issue of the comic book's perceived independence and credibility as a reflection of the investigative work of the ICTR. Young Rwandans questioned the tribunal's trustworthiness, perceiving it as biased on account of its international nature and its presumed susceptibility to political manipulation by dominant Western powers. The ICTR, as the author of the book, appeared to them as a foreign and distant mechanism which could not possibly speak for Rwandans and their experiences. Against this backdrop, when asked whether they thought the material could be used in schools, the respondents echoed concerns more obliquely expressed by Rwandan teachers, widely concurring that "it should first be checked by the government to see if it's completely correct and whether it tells the real truth." ${ }^{\prime 9}$ It is notable here that the response both assumes a particular "real truth" and specifically credits "the government" with the status of its reliable arbiter.

One respondent of Congolese origin, living and studying in Rwanda, likewise accused the book of covering up the truth via omission. Hesitant to publicly express a personal view that he considered "problematic in this country" due to its deviation from the Rwandan master-narrative, this respondent took me aside in order to criticize the book's glossing over of the tragic impact of the genocide on neighbouring DR Congo after the mass exodus of Hutu refugees. He complained that "this book doesn't show how my people also suffered ... after the Rwandan army decided to attack and hunt down their Hutu enemies in our beloved country." 80 The book's introductory note specifies its aim to communicate to a regional audience, an aim this respondent's critical reaction indicates it may not achieve due to its avoidance of what remains a salient and a highly controversial issue in this region's shared recent history. ${ }^{81}$

Confirming findings on popular views of TJ mechanisms in both Sierra Leone and Rwanda, ${ }^{82}$ the fieldwork further suggested that these outreach documents

78 Youth FGD1, Kigali, 24 April 2015.

79 Youth FGD2, Kigali, 4 May 2015.

80 Conversation in French after FGD2, Kigali, 4 May 2015.

81 Denise Bentrovato, “Accounting for Violence in Eastern Congo: Young People's Narratives of War and Peace in North and South Kivu," African Journal on Conflict Resolution 14, no. 1 (2014): 9-35.

82 Gahima, Transitional Justice in Rwanda, 115-117; Gearoid Millar, "Local Evaluations of Justice through Truth Telling in Sierra Leone: Postwar Needs and Transitional Justice," Human Rights Review 12, no. 4 (2011): 515-535; Rosalind Shaw, "Memory Frictions: Loca- 
had ultimately failed to positively influence predominantly negative perceptions of the SLTRC and the ICTR, as well as of their respective alleged contributions to societal healing and reconciliation. In Sierra Leone, while "the truth" produced by the TRC retained an image of objectivity, the model of healing through truthtelling seemed to be rejected. A similarly negative response met the proposal of talking about the nation's violent past within the school setting as a necessary, viable and valuable way forward. Such reactions raise questions around the local relevance and cultural sensitivity of what Rosalind Shaw critically defines as "globalized forms of remembering that are imported and promoted through such arenas as Western psychotherapy and truth commissions." ${ }^{83}$ In addition, respondents in Sierra Leone expressed disillusion with the TRC's limited contribution to peacebuilding, having observed the continued presence of some of the root causes and drivers of conflict despite their treatment in the TRC setting. Respondents in Rwanda, where optimism dominated among participants in the study regarding both the present and the future, credited the perceived attainment of positive change exclusively to the government's efforts and to a resilient Rwandan population. The model of international justice, on the other hand, was criticized for its perceived rootlessness in the local context and its insignificant impact on post-genocide recovery. Young Rwandans routinely accompanied their expressions of grief regarding the violent past represented in the ICTR comic book with statements of pride in the triumphant resurrection of the Rwandan nation under the moral, unifying, and patriotic leadership of the current rulers, thus highlighting their perceived primacy of local efforts vis-a-vis international interventions. The young Rwandans also articulated a firm commitment to "never forgetting" and to taking action to prevent the reoccurrence of violence. This sense of responsibility for the future on the part of young people also derives from a bitter understanding and painful lesson, rekindled by the reading of the comic book, of "how naïve we were to think we could rely on the outside world," a "mistake" they were unwilling to repeat. ${ }^{84}$

\section{Conclusion}

This study has analyzed and evaluated two unique sets of TJ outreach materials designed with the stated aim of educating younger generations about their country's recent violent past and its legacy in postwar Sierra Leone and Rwanda

lizing the Truth and Reconciliation Commission in Sierra Leone," International Journal of Transitional Justice 1, no. 2 (2007): 183-207.

83 Rosalind Shaw, Rethinking Truth and Reconciliation Commissions, 7.

84 Youth FGD1, Kigali, 24 April 2015. 
respectively. In so doing, it has provided insights into the potential value and challenges related to the design and implementation of such TJ educational measures and raised questions as to the feasibility and potential modes of their meaningful use in the classroom.

The research findings point to manifold potential for these materials. The innovative and creative comic format they adopt promises to facilitate young people's cognitive and emotional engagement with a topic of both key national and intensely personal current significance. The particular formats of the materials render them accessible and potentially powerful media for the exploration of sensitive topics and for the simultaneous advancement of such TJ aims as documenting the nature and extent of violence and its consequences, acknowledging victims' experiences and suffering, and establishing accountability. The research, however, also uncovered limitations in the extent to which these materials can promote young people's understanding of past violence, its particularities and complexities. Specifically, such limitations include omission and simplification, insufficiencies in historical contextualization, and an inadequate exploration of the perspectives and humanity of perpetrators. The research also unveiled an over-concern with conveying the horrors of war, with the potential both to (re)traumatize readers and to overshadow critical reflection on the causes and dynamics of the violence, thus potentially compromising progress toward peace and reconciliation.

Beyond their inherent features, the perceived legitimacy and potential impact of these measures were subject to substantial influences and constraints arising from local political and social contexts, particularly from dominant discourses and prevailing politics and practices of memory. In both Sierra Leone and Rwanda, specificities of context, characterized respectively by a pervasive culture of silence and a hegemonic official memory, led teachers to refrain from using these alternative resources. In both cases, teachers showed caution and resistance toward employing non-curricular materials that they perceived as possibly challenging the status quo and requiring them to step out of their comfort zone, taking risks they considered unnecessary.

While recognizing such challenges and pitfalls, the findings of this study might suggest that the most valuable use of these resources in the classroom, given adequate preparation by teachers, may lie in their analysis and interpretation in exercises in critical and historical thinking. An approach inspired by critical pedagogy and an inquiry-based and interpretative approach to history education would neither present them uncritically in the classroom nor reject them outright, but instead treat them as cultural artifacts which, like school textbooks, "are conceived, designed, and authored by real people with real in- 
terests," ${ }^{\prime 5}$ and are therefore inevitably selective and susceptible to bias. Such resources may also serve as means to encourage students to reflect on questions around the possibilities, challenges and limits of representing violent pasts and on the associated politics of representation.

This exploratory study is an initial and partial consideration of evaluative approaches to TJ school and youth outreach programs in postwar societies. Further necessary research should aim at assessing the impact and effectiveness of such TJ educational interventions. Its ultimate end may be to inform the development of innovative strategies for engaging young people with violent pasts and their aftermath in a manner that produces benefits and does not inflict further harm.

\section{Bibliography}

Ainley, Kirsten, Rebekka Friedman and Chris Mahony, eds. Evaluating Transitional Justice: Accountability and Peacebuilding in Post-Conflict Sierra Leone. London: Palgrave Macmillan, 2015.

Apple, Michael W. Official Knowledge: Democratic Education in a Conservative Age. New York: Routledge, 1993.

Bachmann, Klaus and Aleksandar Fatić. The UN International Criminal Tribunals: Transition Without Justice. London/New York: Routledge, 2015.

Baetens, Jan and Hugo Frey. The Graphic Novel: An Introduction. New York: Cambridge University Press, 2014.

Barker, Chris. Cultural Studies: Theory and Practice. 4th edition. London/Thousand Oaks: SAGE, 2011.

Bentrovato, Denise. “Accounting for Violence in Eastern Congo: Young People's Narratives of War and Peace in North and South Kivu." African Journal on Conflict Resolution 14, no. 1 (2014): 9-35.

Bentrovato, Denise. Narrating and Teaching the Nation: The Politics of Education in PreAnd Post-Genocide Rwanda. Göttingen: V\& R unipress, 2015.

Bentrovato, Denise, Karina V. Korostelina and Martina Schulze, eds. History Can Bite: History Education in Divided and Postwar Societies. Göttingen: V\& R unipress, 2016.

Brozo, William G., Gary Moorman and Carla Meyer, eds. Wham! Teaching with Graphic Novels Across the Curriculum. New York: Teachers College Press, 2014.

Caulker, John. "Foreword." In TRC Report: A Senior Secondary School Version, edited by Mohamed Sheriff and Elvira M. J. Bobson-Kamara, 4. Sierra Leone: Truth and Reconciliation Working Group, 2005.

Christensen, Lila L. "Graphic Global Conflict: Graphic Novels in the High School Social Studies Classroom.” The Social Studies 97, no. 6 (2006): 227-230.

85 Michael W. Apple, Official Knowledge: Democratic Education in a Conservative Age (New York: Routledge, 1993), 46. 
Clark, Janine Natalya. "International War Crimes Tribunals and the Challenge of Outreach.” International Criminal Law Review 9 (2009): 99-106.

Clark, Philip and Zachary Kaufman. After Genocide: Transitional Justice, Post-Conflict Reconstruction, and Reconciliation in Rwanda and Beyond. Columbia/Hurst: Columbia University Press, 2009.

Cole, Elizabeth A., ed. Teaching the Violent Past: History Education and Reconciliation. Lanham, MD: Rowman \& Littlefield, 2007.

Cromer, Michael and Penney Clark. "Getting Graphic with the Past: Graphic Novels and the Teaching of History." Theory and Research in Social Education 35, no. 4 (2007): 574-591.

Dugal, Zoe. "Outreach to Children in Transitional Justice Processes in Sierra Leone." In Transitional Justice and Education. Learning Peace, edited by Clara Ramírez Barat and Roger Duthie. New York: SSRC, 2016.

Frey, Hugo and Benjamin Noys, eds. History in the Graphic Novel. Special issue of Rethinking History 6, no. 3 (2002).

Gahima, Gerald. Transitional Justice in Rwanda: Accountability for Atrocity. New York: Routledge, 2013.

Gberie, Lansana. A Dirty War in West Africa: The RUF and the Destruction of Sierra Leone. Bloomington: Indiana University Press, 2005.

Gellman, Mneesha. "Only Looking Forward: The Absence of National History in Sierra Leone." In History Can Bite: History Education in Divided and Postwar Societies, edited by Denise Bentrovato, Karina V. Korostelina and Martina Schulze. Göttingen: V\&R unipress, 2016.

Gross, Zehavit and E. Doyle Stevick, eds. As the Witnesses Fall Silent: 21st Century Holocaust Education in Curriculum Policy and Practice. Cham: Springer, 2015.

International Holocaust Remembrance Alliance (IHRA). "IHRA Resources Guide." https://www.holocaustremembrance.com/educate/teaching-guidelines, accessed 9 March 2016.

Jalloh, Charles Chernor and Andrew Morgan. "International Criminal Justice Processes in Rwanda and Sierra Leone: Lessons for Liberia." In Shielding Humanity: Essays in International Law in Honour of Judge Abdul G. Koroma, edited by Charles Chernor Jalloh and Olufemi Elias, 447-509. Leiden/Boston: Brill Nijhoff, 2015.

Karwande, Maya. "Implementing an Engagement Model: Outreach at the Special Court for Sierra Leone." In Transitional Justice, Culture and Society: Beyond Outreach, edited by Clara Ramirez-Barat. New York: Social Science Research Council, 2014. 49-96.

Keen, Davi. "Greedy Elites, Dwindling Resources, Alienated Youths: The Anatomy of Protracted Violence in Sierra Leone.” International Politics and Society 2 (2003): 67-94.

Kubert, Joe. Fax from Sarajevo: A Story of Survival. Milwaukie, OR: Dark Horse Comics, 1996.

Lambourne, Wendy. "Outreach, Inreach and Civil Society Participation in Transitional Justice." Critical Perspectives in Transitional Justice, edited by Phil Clark. Cambridge: Intersentia, 2013. 235-261.

Majola, Bongani. "Welcoming Note." In Bocar Sy, 100 Days in the Land of the Thousand Hills. Arusha: ICTR, 2014. 4.

Mayersen, Deborah. "One Hundred Days of Horror: Portraying Genocide in Rwanda." Rethinking History: The Journal of Theory and Practice 19, no. 3 (2015): 357-369. 
McLoud, Scott. Understanding Comics: The Invisible Art. New York: Kitchen Sink Press, 1993.

Millar, Gearoid. "Local Evaluations of Justice through Truth Telling in Sierra Leone: Postwar Needs and Transitional Justice." Human Rights Review 12, no. 4 (2011): 515-535.

Parker, Robert Dale, ed. Critical Theory: A Reader for Literary and Cultural Studies. New York: Oxford University Press, 2012.

Parmar, Sharanjeet, Mindy Jane Roseman, Saudamini Siegrist and Theo Sowa, eds. Children and Transitional Justice. Truth-Telling, Accountability and Reconciliation. Cambridge: Harvard University Press, 2010.

Patton, Michael Quinn. Qualitative Research \& Evaluation Methods: Integrating Theory and Practice. $4^{\text {th }}$ edition. London/Thousand Oaks: SAGE Publications, 2014.

Paulson, Julia. "The Educational Recommendations of Truth and Reconciliation Commissions: Potential and Practice in Sierra Leone." Research in Comparative and International Education 1, no. 4 (2006): 335-350.

Paulson, Julia. “'Whether and How?' History Education about Recent and Ongoing Conflict: A Review of Research.” Journal on Education in Emergencies 1, no. 1 (2015): 14-47.

Peskin, Victor. International Justice in Rwanda and the Balkans. Virtual Trials and the Struggle for State Cooperation. New York: Cambridge University Press, 2009.

Ramírez-Barat, Clara. Making an Impact. Designing and Implementing Outreach Programs for Transitional Justice Measures. New York: ICTJ, 2011.

Ramírez-Barat, Clara. Engaging Children and Youth in Transitional Justice Processes: Guidance for Outreach Programs. New York: ICTJ, 2012.

Ramírez-Barat, Clara, ed. Transitional Justice, Culture and Society: Beyond Outreach. New York: Social Science Research Council, 2014.

Roht-Arriaza, Naomi and Javier Mariezcurrena, eds. Transitional Justice in the TwentyFirst Century: Beyond Truth versus Justice. Cambridge: Cambridge University Press, 2006.

Rotberg, Robert I. and Dennis Thompson. Truth versus Justice: The Morality of Truth Commissions. Princeton, NJ: Princeton University Press, 2000.

Sacco, Joe. Safe Area Gorazde: The War in Eastern Bosnia, 1992-1995. Seattle, WA: Fantagraphic Books, 2000.

Sacco, Joe. Palestine, Seattle. WA: Fantagraphic Books, 2001.

Shaw, Rosalind. Rethinking Truth and Reconciliation Commissions: Lessons from Sierra Leone. Washington, DC: USIP, 2005.

Shaw, Rosalind. "Memory Frictions: Localizing the Truth and Reconciliation Commission in Sierra Leone." International Journal of Transitional Justice 1, no. 2 (2007): 183-207.

Sheriff, Mohamed and Elvira M. J. Bobson-Kamara. TRC Report: A Senior Secondary School Version. Sierra Leone: Truth and Reconciliation Working Group, 2005.

Sierra Leone Truth and Reconciliation Commission. Witness to Truth: Report of the Sierra Leone Truth and Reconciliation Commission. Freetown: SLTRC, 2004.

Sierra Leone Truth and Reconciliation Commission. Truth and Reconciliation Commission Report for the Children of Sierra Leone: Child-Friendly Version, Freetown: UNICEF, 2004. 
Spiegelman, Art. Maus, A Survivor's Tale I: My Father Bleeds History. New York: Pantheon Books, 1986.

Spiegelman, Art. Maus, A Survivor's Tale II: And Here My Troubles Began. New York: Pantheon Books, 1991.

Sy, Bocar. 100 Days in the Land of the Thousand Hills. Arusha: ICTR, 2014 [first published in 2011].

Syma, Carrye Kay and Robert G. Weiner, eds. Graphic Novels and Comics in the Classroom: Essays on the Educational Power of Sequential Art. Jefferson, NC: McFarland, 2013.

Waldorf, Lars. "'A Mere Pretense of Justice': Complementarity, Sham Trials, and Victor's Justice at the Rwanda Tribunal." Fordham International Law Journal 33, no. 4 (2010): 1221-1277.

Waller, James. Becoming Evil: How Ordinary People Commit Genocide and Mass Atrocity. New York: Oxford University Press, 2002. 


\section{Education Reforms in Transitional Justice Contexts: Memory Studies versus Human Rights Education in Morocco}

I want the state to acknowledge the heroic fight of Mohand [Mohammed] ben Abdelkrim el Khattabi against French and Spanish colonialism. It [the Rif Republic] was an experience of freedom, and we have the right to be proud of it. They [the regime] should let us be proud of it. They should let us teach it to our children in history textbooks.

Hakim Benchemmas, former victim of repression, Instance Equité et Réconciliation, public hearings, el Hoceima, 2005.

The "years of lead" between 1956 and 1999 undoubtedly constituted the most violent period in the modern history of Morocco, marked by state violence and massive human rights abuses against regime opponents, democracy activists, and the society at large. The Equity and Reconciliation Commission (Instance Equité et Réconciliation, IER), a state-sanctioned truth and reconciliation commission (TRC), was established in 2004 to expose a violent past extending over more than forty years of political repression and the systematic use of torture. Unprecedented in the Arab and Muslim worlds, Morocco's IER organized a series of public hearings where witnesses shared their stories of victimization without, however, naming their torturers. While this has resulted in an official narrative promoting a forward-looking, justice-based approach built around reconciliation, societal cohesion and a break with the past, the perpetrators have neither been prosecuted nor removed from office.

In its final report, the IER recommended constitutional and institutional reforms as well as remembrance initiatives to honor the victims and (re)write the nation's history as means to prevent the recurrence of violence. In 2009, the Instance Equité et Réconciliation 2 (IER 2), a state-sponsored and EU-funded project, sought to implement memorialization measures in various contexts, including archives, cinema, historiography, and education. Under the auspices of the National Council for Human Rights (Conseil National des Droits de l'Homme, $\mathrm{CNDH}),{ }^{1}$ the University of Mohammed V in Rabat launched the master's pro-

1 The $\mathrm{CNDH}$ is the national human rights institution responsible for the protection and promotion of human rights in Morocco. Although the CNDH partially complies with the Paris Principles, which set out the minimum criteria for national human rights institutions to be credible and effective state institutions, its mandate remains limited and its status is an 
gram Histoire du Temps Présent to encourage research into and the study of Morocco's contemporary history and collective memory. The program faced many obstacles after the CNDH failed to secure funding and, most importantly, access to the IER archives for its researchers. Instead, The Council supported the establishment of so-called "Human Rights Clubs" in primary and secondary schools throughout the country in order to cultivate a culture of human rights in future generations of Moroccans.

This chapter analyzes these educational initiatives in the context of Morocco's transitional justice processes. To this end, it first contrasts the narratives resulting from Morocco's TRC with the official history presented to students in history textbooks in primary and secondary schools. The chapter also examines the reasons behind the failure of the memory program Histoire du Temps while shows how Human Rights Clubs, which encouraged a forward-looking form of peace education, were supported and funded by both the $\mathrm{CNDH}$ and the EU.

\section{Morocco's Heavy Legacy of Human Rights Violations}

By the time the international community had been alerted to the human rights situation in Morocco, the regime had detained and tortured tens of thousands of militants and their families and disappeared and killed hundreds. To determine the number of victims of grave human rights violations in Morocco, American Anthropologist Susan Slyomovics proposed to "add five to every known victim of arrest and detention in order to account for friends, family, neighbors and random passers-by." 2 In 2000, a former agent of the Moroccan secret services advanced a different figure. Ahmad Boukhari estimated that a total of 13,500 kidnappings and forced disappearances occurred between 1960 and 1973 when he was in service. To account for the total number of victims between 1956 and 1999, Slyomovics suggested that Boukhari's figure needed to be doubled or tripled. ${ }^{3}$ In 1991, Amnesty International reported the existence of over 350 political prisoners from Morocco and Western Sahara, and 900 cases of forced disappearance. It also deplored the fate of 61 prisoners in the secret desert prison at Tazmamart, twenty-four of whom had already died. ${ }^{4}$ In 1998, the CNDH published a controversial list limiting the number of forcibly missing cases to

advisory one. The CNDH's budget originates directly from the Palace, making it dependent on and only accountable to the king. For more on this, see http://www.cndh.org.ma/fr.

2 Susan Slyomovics, The Performance of Human Rights in Morocco (Philadelphia: University of Pennsylvania Press, 2005), 48.

3 Ibid, 50.

4 Amnesty International, Les Disparus: le mur du silence doit tomber, April 1993 (AI Index: MDE 29/01/93), 2-6. 
$112 .^{5}$ A year later, an indemnity commission approved and compensated 3,681 cases related to disappearance and arbitrary detention. ${ }^{6}$ And by the time Morocco's IER finished its investigation and reparation program in 2007, 23,676 people had been compensated for human rights violations endured between 1956 and 1999. ${ }^{7}$

The large discrepancy between these numbers is indicative of the change in the regime's discourse regarding human rights abuses in Morocco. It demonstrates how the state moved from a policy of silence and repression to a discourse of acknowledgment and justice. After forty years of politics based on terror and oppression against all voices of dissent, the state adopted a stance of redressing past wrongdoings by offering Moroccan people and opposition groups a new social contract based on a liberal discourse of human rights and the rule of law. Thanks to institutions such as the $\mathrm{CNDH}$ and the IER, the regime positioned itself as the new protector of human rights in Morocco even while attempting to silence former and new victims and co-opt opposition groups that contested its hegemony over the process of transitional justice.

\section{Transitional Justice Narratives in Morocco}

The most notable achievement of Morocco's transitional justice project was the organization of public hearings where victims exposed their experiential truth regarding past human rights violations. However, the discourse resulting from the very official IER audiences was constrained by time limits and the fact that victims were forbidden to name wrongdoers. Victims were carefully selected, and recordings were edited in order to highlight narratives of reconciliation and a new era in Morocco. To counter this, civil society - led by the human rights organization Association Marocaine des Droits Humains (AMDH) - held its own alternative public hearings in the same cities and at the same time as the IER hearings. The AMDH provided the victims with the opportunity to name their torturers and complement and/or resist the official discourse, even featuring recent victims detained in relation to the regime's ongoing repression of Islamists and Sahrawi separatists. Thanks to both forums, Moroccans were thus able to recover historical facts once erased from their collective memory and national history. One after the other, survivors shared their stories of systematic

5 Veerle Opgenhaffen and Mark Freeman, Transitional Justice in Morocco: A Progress Report (New York: International Center for Transitional Justice, 2005), 9.

6 Ibid, 10.

7 USIP, “Truth Commission: Morocco.” https://www.usip.org/publications/2004/12/truthcommission-morocco accessed May 18, 2017. 
abuse that took the form of collective punishment against families, tribes, neighborhoods, and entire regions.

The Rif events of 1958 and 1959 provide a good example in this regard. Following Morocco's independence in 1956, the northern region of the Rif had become an arena for settling accounts and acts of sabotage between the palace and other power contenders like the nationalist Istiqlal party, culminating in a local rebellion in the winter of 1958. The brutal repression of the Rif and its populations was carried out by the royal army under the command of Crown Prince Moulay Hassan. ${ }^{8}$ His close associate and head of secret services, General Mohammed Oufkir, was identified as "the butcher of the Rif" in reference to his bloody repression. ${ }^{9}$ The latter took the form of a collective punishment against the entire region and tribes of the Rif, and included expropriation, crop-burning, rape, forced disappearances, torture, mass executions and the displacement of the population. The Aith Waryaghar was particularly targeted as it was the tribe of ben Abdelkrim el Khattabi, the guerrilla leader who inflicted a historic defeat on Spanish troops in the Rif War of 1921. El Khattabi also founded the Rif Republic between 1921 and 1926, which challenged the Alaoui dynasty's claim to the region.

Punishment by affiliation occurred again in the 1960s and 1970s against former resistance fighters from the Moroccan Liberation Army that had secured the country's independence, and against leftist opposition political parties, notably the Union National des Forces Populaires, led by the emblematic Mehdi Ben Barka. Arbitrary detention and forced disappearances of real and perceived enemies of the state, as well as their kin and friends, would happen each time the regime faced urban or rural rebellion. As a result, thousands of Moroccans were illegally detained and tortured in secret detention centers around the country, notably during the student riots in 1965, the bread riots in 1981 and 1984, and the civil unrest of the 1990s.

When the military attempted to overthrow King Hassan II in 1971 and again in 1972, the regime imposed brutal punishment upon the perpetrators and their families. While the top generals were executed by firing squads, hundreds of cadets were imprisoned, regardless of their involvement or knowledge of the coups. Their families were dispossessed, shunned, and continuously harassed by the local authorities. A year later, fifty-eight cadets were kidnapped from the central prison in the middle of the night and moved to the secret desert jail at

8 Nabil Mouline, "Reconsidering the Rif Revolt (1958-59)," Jadaliyya. http://www.jadaliyya. com/pages/index/20664/reconsidering-the-rif-revolt-(1958-59), accessed 16 April, 2016 and Richard C. Pennell, Morocco Since 1830: A History (New York: New York University Press, 2001), 304-5.

9 Susan G. Miller, A History of Modern Morocco (Cambridge: Cambridge University Press, 2013), 156-158. 
Tazmamart where half of them died and the other half spent more than twenty years in appalling conditions. ${ }^{10}$ Another coup in 1973, this time led by subversive groups in the rural regions of the Middle and High Atlas (Khenifra and Errachidia), would fail, resulting in the elimination of its leaders and the collective punishment of entire tribes.

Similarly, when separatist voices called for self-determination in the contested territories of Western Sahara in 1975, the regime silenced them using the same techniques of mass arrests, collective punishment, forced disappearance and torture that it had used against the rest of Morocco. ${ }^{11}$ The regime was merciless in its repression of Sahrawi children, women, the elderly and activists alike. Dissidents and their entire families were disappeared in secret detention centers. ${ }^{12}$ The protracted war between Morocco and the Algeria-backed Polisario Front drained both camps and created around 100,000 refugees. Although the United Nations brokered a ceasefire in 1991, hostilities continue between the two camps with alleged repression of Sahrawi civilians to this day. ${ }^{13}$

These narratives, as established by academics and witnessed by many survivors, are absent from the consciousness of the majority of Moroccans. While the recent transitional justice episode has allowed for some of these stories to resurface in public hearings and official publications by the $\mathrm{CNDH}$, most have remained erased from the national curricula. The following sections examine the selective process of remembrance in Morocco through the analysis of educational programs set up by the regime to commemorate, (re)write, and teach its violent past to Moroccans. The first section introduces the project Instance Equité et Réconciliation 2 (IER 2) and investigates the large number of initiatives, notably archives, museums, and memorial sites, that were halted because of the unwillingness of the state to seriously engage in this process. The second section examines education reforms launched after the 2004 transitional justice episode by analyzing history and civic education textbooks in Morocco. The study allows for a better understanding of the regime's policy to support and fund initiatives geared towards a break with the past versus initiatives that seek to investigate it. In so doing, it identifies some challenges and drawbacks facing commemoration processes in transitioning countries, especially in the field of education.

10 Marguerite Rollinde, Le Mouvement Marocain des Droits de l'Homme (Paris: Karthala, 2002), 174.

11 Amnesty International, Les Disparus, 2-6.

12 Ibid., 27.

13 Amnesty International, "Morocco/Western Sahara: New arrests and allegations of torture of Sahrawi human rights defenders." 26 August, 2005, http://www.amnesty.org.au/news/com ments/482/, accessed June 12, 2017. 


\section{The Politics of Memory in Morocco}

Following the work of the IER, and adopting some of the recommendations of its final report in 2009, the National Council for Human Rights launched IER 2: Archives, History and Memory, a project that sought to "positively preserve the memory and the history of Morocco." ${ }^{14}$ This work on memory and history, developed at the state level and led by royal advisors, became an institutional process aimed at the reconciliation of Moroccans with their violent past. With a generous grant from the European Union nearing eight million euros, under the IER 2 Project, the regime launched numerous initiatives including the establishment of a national archive institution and several centers of historical research, the creation of postgraduate degrees on memory and contemporary history, the publication of history books, the founding of museums, and the transformation of detention centers into memorial sites. The state also financed the production of documentary films about the past and promoted other nonofficial truth-telling projects such as victims' memoirs and fiction films about the repressive past, adapting them to fit the official narrative. Regrettably, numerous projects remained work in progress, revealing a certain fragility of the initiative.

An obvious example that illustrates the limited interest of the regime in addressing its violent legacy is the establishment of the Archives du Maroc. ${ }^{15}$ While the creation of a national institution to host the files collected by the IER stood as an obvious recommendation in the commission's final report, the law regulating access to the enormous amount of sensitive information did not come through easily. In 2007, a royal decree promulgated Law 69/99 relating to the archives; however, the Archives $d u$ Maroc were not established until $2011 .{ }^{16}$ Referring to the absence of a legal framework that would guide and regulate the functioning of the institution, the Archives $d u$ Maroc further delayed public access to the general archives, waiting for the government to ratify a bill in this regard. Although the law was approved in December 2014, the institution has yet to function properly. In 2015, for example, the CNDH and Archives $d u$ Maroc agreed on the terms of reference that would regulate the organization and access to the IER archives. The agreement stipulated that the files, which documented and acknowledged

$14 \mathrm{CNDH}$, “Présentation du Programme IER2: Archives, Histoire Et Mémoire," http://www. cndh.ma/fr/programme-daccompagnement-aux-recommandations-de-lier-en-matiere-dar chives-dhistoire-et-de-memoir-31, accessed June 15, 2016.

15 The Archives du Maroc is an institution created in 2011 with the aim of managing the national public archives via their organization, preservation, and the promotion of research into the past. For more information see http://www.archivesdumaroc.ma/.

16 The Strategy of the Archives du Maroc is available at http://www.archivesdumaroc.ma/page/ strategie.html. 
the repressive past of the regime, would remain closed, in spite of the IER recommendation in 2005 to organize, preserve, and facilitate access to them.

Something similar happened with the efforts to acknowledge the past via the conversion of detention and torture centers into museums or memorial sites. After numerous roundtables, workshops and international conferences on the best methods for remembering the past, the project was limited, in the end, to the production of a photobook. ${ }^{17}$ The memorialization program, concluded in February 2015, was hindered by property issues and the communities' strong preference for development projects that would generate income instead of memorial sites that stirred unwanted memories of the past, noted Naima Senhaji, the coordinator of IER $2 .{ }^{18}$ For Omar Lamallem, of the local association $\mathrm{La}$ Memoire $d u$ Rif, the state has no genuine will to build a memorial site or a museum that would continuously remind young Riffians of the bloody events perpetrated in the region in 1958, 1959, and again in $1984 .{ }^{19}$ Between bulldozed or run-down buildings and the older generation, the memory of former victims and detention sites is dying out; all the more reason for a focus on memory studies and history education in times of transition.

\section{Education in Transitional Justice Contexts: Memory Studies versus Human Rights Education}

\section{Memory Studies: l'Histoire du Temps Présent}

When the IER investigated the legacy of the "years of lead" based on victims' testimonies and key witnesses, the official discourse reminded the public that these historical narratives were subjective. ${ }^{20}$ Stressing the traumatic nature of past experiences, the fallible nature of memory, and the enforced structure of the testimonies, Moroccan officials endeavored to differentiate between historical truth and personal memories, calling for a sound exercise in history-writing based on scientific methods. With this aim in mind and as part of the IER 2 project discussed above, academic research and intellectual inquiry into the recent and immediate past of Morocco were encouraged through the establishment of the memory studies program Histoire du Temps Présent. The program recruited Morocco's most renowned academics, including Mohammed Kenbib,

17 The CNDH, L'enfermement et le partage: lieux et mémoire, 2015. http://www.cndh.org.ma/fr/ ouvrages/lenfermement-et-le-partage-lieux-et-memoire, accessed 15 October, 2017.

18 Naima Senhaji, the coordinator of IER 2, interview with author, Rabat, June 2015.

19 Omar Lamaallem, interview with author, Al Hoceima, December 2015.

20 Driss Yazami, president of the CNDH, interview with author, Rabat, June 2015. 
Jamaa Baida, Abdelahad Sebti, Mostafa Bouaziz and Abdelhay Moudden. Each offered a course (one unit) on his subject of expertise, including research methods, archives, oral history, memory studies, globalization, movements of contestation, and the history of the elites.

The master's program sought to link theoretical knowledge with the practical aspects of history through training in data collection and evaluation provided at partnering institutions including the $\mathrm{CNDH}$ and the Archives du Maroc. Other partnering institutions included the Faculty of Law and the University of Communication in Morocco, the April $9^{\text {th }}$ University in Tunis, the Institute of Contemporary History in Paris and la Maison Méditerranéenne des Sciences Humaines (MMSH) in Aix-en-Provence. Students could also undertake archive research in the Moroccan Cinematographic Center (Centre Cinématographique Marocain, CCM) which owns significant video clips and documentaries produced during and about the "years of lead."

Despite the robust program and the expertise of faculty members running it, Histoire du Temps Présent was a lost opportunity for memory recovery. The proposed syllabus aimed at forming competent researchers by tapping into available sources (written, oral, and visual) both inside and outside Morocco to help research and re-write parts of its independent history (including archives in Spain and France, for example). It also offered students contact with contemporary sources and eyewitness accounts thanks to an engaged civil society, such as the AMDH, which understood the importance of documenting and teaching the past to prevent its recurrence and to fight impunity. Unfortunately, educational initiatives as part of a transitional justice project have proved to be challenging. Scholars and practitioners alike have agreed that, due to many political and social factors, transitioning societies often struggle to implement effective education reforms. ${ }^{21}$ In the case of Morocco, Histoire du Temps Présent turned out to be a frustrating exercise in historical research. Students reported their inability to choose their research topics freely. Thesis supervisors often censored them because their research questions were problematic and touched upon sensitive issues. ${ }^{22}$ More importantly, access to the written and media archives of the IER was limited as were the archives of the royal palace. ${ }^{23}$

21 On this see, for example, Elizabeth A. Cole, "Transitional Justice and the Reform of History Education," International Journal of Transitional Justice 1, no. 1 (2007): 115-137, and Clara Ramírez-Barat and Roger Duthie, Education and Transitional Justice: Opportunities and Challenges for Peacebuilding (New York: International Center for Transitional Justice and UNICEF, 2015).

22 Hicham Cherkaoui, interview with author, Rabat, June 2015.

23 The author approached the CNDH in the hope of accessing the archives of the IER in June and July 2015, but her request was turned down. American anthropologist Susan Slyomovics was able to access Fatna el Bouih's IER file because she seems to have had the consent of the victim 
As a result, the postgraduate program, set up by IER 2 to encourage research into and the study of Morocco's contemporary history and post-independence memory, was terminated after only two years. "I put full responsibility on the $\mathrm{CCDH}$ and its chairman Driss Yazami for the failure of this master program. How could students research the memory of Morocco without access to IER archives?" asked Hicham Cherkaoui, a member of AMDH and law professor at the University of Mohammed V in Rabat. ${ }^{24}$ When the Council signed a convention with this university to create a master's degree in contemporary history at the faculty of Arts and Humanities, the CNDH vouched to support its field investigations, secure books and other resources, and invite international lecturers in contemporary history to conferences and seminars, just as it promised students full access to IER archives. ${ }^{25}$ The program could not sustain itself without funding, explained Jilali el Adnani, a history professor and the coordinator of Histoire $d u$ Temps Présent at the University of Mohammed V. ${ }^{26}$

Instead, the $\mathrm{CNDH}$ seems to have favored a forward-looking approach to peace education. In contrast to Histoire $d u$ Temps Présent, Citizenship and Human Rights Clubs in secondary schools throughout the kingdom focused on cultivating a culture of citizenship and human rights without necessarily relating them to the violent past and the sociopolitical realities of the country. Indeed, as will be argued later, the $\mathrm{CNDH}$ showed more enthusiasm toward supporting these initiatives through multiple regional partnerships with the Ministry of Education and civil society actors. Before addressing this, however, the following section examines Moroccan textbooks of history and civic education in order to expose how Morocco's experiences of transitional justice influenced their content.

Independent Morocco in Moroccan History Textbooks

When in 1990 Lucette Valensi analyzed the process of official memory formation in Morocco, she noted that many blank pages punctuated its postcolonial his-

and the cooperation of the $\mathrm{CNDH}$ presidency, often granted to foreign researchers unlike to Moroccan scholars.

24 Hicham Cherkaoui, law professor at the Mohammed V University in Rabat and coordinator of the Moroccan Coalition to the International Criminal Court, interview with author, Rabat, June 2015.

$25 \mathrm{CNDH}$, "Signature d'une convention de partenariat entre le CCDH et l'université Mohammed V-Agdal sur la création d'un master d'histoire contemporaine." http://www.cndh.org.ma/fr/ partenaires-nationaux/signature-dune-convention-de-partenariat-entre-le-ccdh-et-luniver site-mohammed, accessed June 12, 2017.

26 Jillali El Adnani, Professor of History at the Faculty of Humanities and Social Sciences at the University of Mohammed V in Rabat, interview with author, Rabat, June 2015. 
tory. ${ }^{27}$ The skeletons in the closet (les cadavres dans le placard), as she ironically referred to them, concerned many events and actions of political leaders that negatively impacted on the legitimacy of the monarchic regime. Amongst these were the establishment of the Rif Republic by ben Abdelkrim in 1921, when the rest of Morocco was grappling with colonialism; the military coups that sought to depose King Hassan II in 1971 and 1972, and also the uprisings of 1959 in the Rif, 1965 in Casablanca, 1973 in the Middle and High Atlas as well as periods of unrest in 1981 and 1984. When the thorny topic of Western Sahara is broached, it is presented as part of Morocco's rightful struggle for independence from colonialism. As such, the Green March, which allowed Morocco to take back control of the territories in 1975, is celebrated as one of the main achievements of King Hassan II, without mentioning the human costs that resulted from the protracted conflict with the separatist movement, the Polisario Front. Valensi explained that the regime constructed an official memory based on two main protagonists, King Mohammed V and King Hassan II, while other liberation heroes or political opponents were consigned to anonymity or incorporated into abstract concepts such as "the country," "the nation," and "the people."28

Mustapha Hassani Idrissi, a Moroccan historian and specialist in didactics, has noted that Moroccan textbooks present a national history "with neither head nor tail," beginning with the advent of Islam in the region and ending with the country's independence in $1956 .{ }^{29}$ Indeed, it was only in 2002 that the Ministry of Education implemented a series of reforms that revisited school textbooks. ${ }^{30}$ Carried out in complete opacity, the 2002 reforms did indeed allow for a new pedagogical method of teaching that moved away from mere historical factlearning to methods based on critical thinking and fact-formation. Nevertheless, although the new reform offered multiple textbooks (sanctioned by the Ministry of Education) to students, the curriculum still focused on one narrative: the

27 Lucette Valensi, "Le roi chronophage. La construction d'une conscience historique dans le Maroc postcolonial," Cahiers d'Études Africaines 30, no. 119 (1990) (Maghreb: récits, traces, oublis): 279-298.

28 Ibid., 292.

29 Mostafa Hassani-Idrissi, "Manuels d'histoire et identité nationale au Maroc," Revue internationale d'éducation de Sèvres 69 (2015): 53-64.

30 Before 2002, Morocco's educational system had already undergone two other reforms. The reform of 1970 implemented an arabization policy that replaced French as the main language of learning. The second, in 1987, removed philosophy and other subjects inspiring critical thinking from the national curriculum. These were replaced by Islamic studies that stressed archaic concepts such as obedience to the ruler and the unity of the Islamic community. In 2006, King Mohammed VI created a national council of education and, in 2009, an emergency program for education. For more on this see http://www.men.gov.ma/Ar/Pages/Accueil. aspx\#, accessed 29 January, 2018. At the time of writing, another education commission is considering reforms of the Moroccan educational system and curricula. Latifa Jbabdi, a former IER commissioner, is involved in this process. 
official history as depicted and constructed by the winners; that is, the regime that perpetrated those human rights violations.

In Moroccan history textbooks, the focus remains throughout the grades on the national identity that has transcended the pluralist culture of Moroccan society. Students are invited to think about their country as a nation that was under foreign attack following the advent of Islam. Since 2002, the contemporary and postcolonial history of Morocco has been taught as of the third year of middle school; however, the focus is on the movement leading to the independence of the country and the period immediately following it. ${ }^{31}$ This research surveyed all history textbooks used in Moroccan secondary schools (collège and lycée) and published after the 2002 reforms, referred to as "third generation textbooks." Although they are authored by different historians and printed by different publishing houses, their contents (units, sources, photographs, and charts, for instance) are the same. ${ }^{32}$

King Mohammed V, the "liberator" of Morocco, and King Hassan II, who built the modern state as it is today, are presented in these textbooks as symbols of the independent Morocco. When names and portraits of liberation leaders, such as Mohammed Bel Hassan el Ouazzani or Allal el Fassi, are included, they are mentioned in relation to both kings and relegated to secondary roles. Ben Abelkrim el Khattabi is cited as a resistance fighter (muqawim) who defeated Spanish colonialist troops in the Battle of Anoual in 1921. However, nothing is mentioned about the independent Rif Republic he established following his historic win, and which he ran as a modern nation-state for five years before it was crushed by the Spanish and French armies, who reportedly used chemical weapons against the Riffians. ${ }^{33}$ Instead, the battle of Anoual has been appropriated by the regime as the precursor of the nationalist movement that secured Morocco's independence, led by King Mohammed V, and thus celebrated as an achievement of the Alaoui dynasty.

At the end of each unit, a glossary (al-mo'jam) introduces Moroccan students to the main figures of Morocco's history. These mini-biographies usually include

31 The Moroccan education system resembles that of France. Primary school begins at age 7 and consists of six levels. The first cycle of secondary school, collège (middle school or junior high), has three levels and the second cycle, lycée (high school), comprises three grades.

32 This analysis is based on the following: al Shamil fi al Tarikh, $2^{\text {nd }}$ year of high school (Casablanca: al Nashir al Atlassi, 2007), Fada' al ijtima'iyat, $2^{\text {nd }}$ year of junior high, Cycle préparatoire (Rabat, Imprimerie El Maarif, 2004), fi rihab tarikh, Year 2 of high school (Rabat: dar al alamiya lil kitab, 2007), an-najah fi al-ijtima'iyat, year 2 junior high (Casablanca: Imprimerie Najah al Jadida, 2004) and manar al ijtima'iyat, year 3 of junior high (Casablanca: Top Editions, 2006).

33 On the Rif Republic and the Rif War, see Richard C. Pennell, A Country with a Government and a Flag: The Rif War in Morocco, 1921-1926 (Wisbech: Middle East and North African Studies Press, 1986). 
the person's name, date and place of birth, educational level and political career. They sometimes include political affiliations, ideologies, and publications as well as their contribution to the resistance movement. In some cases, the biographies also mention the consequences of their activism (exile by place and period). For Mehdi Ben Barka, the two-line biography notes his dates of birth and death, his political achievements as the co-signer of Morocco's declaration of independence, and his detention by the French colonial government until 1945 and again in 1951. Also included are Ben Barka's appointment as the chairman of Morocco's first parliament (advisory council) in 1956 and his election as president of the political committee of the Asian-African solidarity organization in 1960. This brief biography appears in a unit that introduces the national resistance movement against France in Morocco. ${ }^{34}$ Nothing is mentioned, however, of Ben Barka's leadership of the opposition movement against the regime which eventually led to his exile and "disappearance" in $1965 .{ }^{35}$

History textbooks produced after 2002 repeatedly refer to "the democratic principles upon which modern Morocco was built." However, no details are provided and focus is placed on the institutional building rather than on the political system. More details are provided in the $12^{\text {th }}$ grade (Year 3 of lycée). The last unit of the history curriculum presents the contemporary history of modern Morocco over three periods: the rule of Mohammed V, of Hassan II, and finally Mohammed VI, across a total of five pages. For the first era, students are invited to compare the political systems among the Arab countries: while Algeria, Syria, Iraq, Egypt, and Tunisia adopted the single-party system, Mauritania and Libya experienced considerable periods of upheaval including revolutions and military coups. ${ }^{36}$ In contrast, King Mohammed V was hailed for his "democratic vision" for the new era of Morocco with a multi-party system and modern constitutional structures. The book notes that this "democratic vision" was hindered by internal and external factors without, however, explaining these or encouraging the student to reflect on them via a critical-thinking activity. Similarly, Hassan II's reign is represented in terms of his projects in the field of economy and social development. The emphasis is placed on the Green March as one of Hassan II's main achievements that saw the "Southern Provinces," as the Moroccan regime refers to Western Sahara, "return to the rest of the country." The king is presented as the unifier of Morocco while there is no mention of the separatist Polisario Front or the large numbers of Sahrawi victims who endured state repression in the aftermath of the Green March.

34 Al Shamel fi al Tarikh, year 2 of baccalaureate (Casablanca: al Nasher al Atlassi, 2007), 167.

35 The Ben Barka dossier remains closed to this date, despite pressure from his family on the IER to shed light on his fate and the conditions of his disappearance.

36 Al Shamel fi al Tarikh, year 2 of baccalaureate, 205.

37 Ibid., 207. 
A most notable addition as of 2002 is the inclusion of Hassan II's economic and political measures between 1961 and 1999. These are summarized in three categories: (1) economic, (2) constitutional and administrative, and finally (3) relating to policy and human rights. His economic achievements are explained by means of additional figures that describe the economic imbalances faced by Morocco in 1980 as well as the responses of the state to counter the disastrous social and economic effects. ${ }^{38}$ There is no mention, however, of the political upheaval or "imbalance" of the period, nor to the fact that, indeed, these economic measures resulted in protests by the population struck by hunger and the brutality of the polices forces. ${ }^{39}$ The book does eventually refer, albeit cautiously, to the political measures with relevance for human rights implemented by King Hassan II in the 1990s. The list is presented without further explanation:

- The Advisory Council for Human Rights (Conseil Consultatif des Droits de l'Homme, CCDH) is established in 1990;

- The release of political detainees and the return of exiled persons in three waves: August 1991, July 1993, and May 1994;

- The establishment of administrative courts and a ministry responsible for human rights in 1993;

- The establishment of the Advisory Council for Social Dialogue in 1994;

- The Constitutional Council;

- Appointment of the democratic alternating government in 1998, headed by Abderrahman el Youssoufi. ${ }^{40}$

This is the first time that the student is introduced to the issue of political prisoners in Morocco and, significantly, this first reference is in relation to their release or return from exile. Although this brief mention comes at the end of the school year and is subject to self-censorship by many teachers, it is highly significant that the concept of political prisoners is included here. Less than a decade ago, the regime of Hassan II invented a new term with which to refer to victims of the "years of lead": the "so-called disappeared" and the "so-called political prisoners." 41

The third generation of Moroccan textbooks was clearly influenced by the political liberalization of Morocco following the ascent of Mohammed VI in 1999. The rule of the current king is introduced by a series of pictures featuring his charitable actions and excerpts from his speeches stressing his commitment

38 Al Shamel fi al Tarikh, year 2 of baccalaureate, Figures 6 and 7, 208.

39 The hundreds of victims killed during these events between 1980 and 1984 are commonly known in Morocco as "the martyrs of the baguette" (shuhada' al kumira).

40 Al Shamel fi al Tarikh, year 2 of baccalaureate (Casablanca: al Nasher al Atlassi, 2007), 208.

41 These expressions were used by King Hassan II in his speech and stated in a CCDH memorandum in 1998. See Slyomovics, The Performance, 44. 
to the establishment of a country based on the rule of law and the protection of human rights. ${ }^{42} \mathrm{~A}$ chart also depicts the advancements of Morocco in the $21^{\text {st }}$ century, including its transitional justice experience, for example "the establishment of the Instance Equité et Réconciliation in December 2003 in order to close the files of human rights abuses and turn the page on the past." ${ }^{43}$ No further details are provided, and the decision as to whether to discuss the topic is left entirely to the teacher. Generally, the section is omitted in class because of its sensitive nature, explains a Moroccan history teacher. ${ }^{44}$ Students are, however, invited to reflect critically on Morocco's "liberal choices" as compared to other countries in the Middle East and North Africa, especially in terms of civic duty and the protection of human rights. More importantly, the 2002 reforms $\mathrm{s}^{45}$ updated the national curricula for civic education on the basis of universal concepts of human rights and individual liberties.

\section{Civic Education and Human Rights Clubs}

Civic education in Morocco is usually addressed by history and geography textbooks, referred to as "social sciences" (al 'ouloum al ijtima'iya or simply al ijtima 'iyat) ${ }^{46}$ This program received a great deal of attention after the enactment of the National Education and Training Charter (CNEF) of 1999 that set raised citizenship awareness and social cohesion via education as national objectives. ${ }^{47}$ Concepts of human rights and democracy were taken into consideration in new textbooks for French, Arabic, social sciences and Islamic education, although this remained conditional on the local realities of Morocco, including, for example, Islamic views on gender equality and freedom of conscience. In Morocco, civic education programs run for six years, beginning in the fourth grade (Year 4 of primary school) and continuing through the tenth grade (Year 3 of middle school). Based on the Vienna Declaration and Programme of Action (VDPA) of

42 Al Shamel fi al Tarikh, year 2 of baccalaureate (Casablanca: al Nasher al Atlassi, 2007), 209, 210.

43 Manar al ijtima'iyat, year 3 of junior high (Casablanca: Top Editions, 2006), 71 and fi rihab tarikh, Year 2 of high school (Rabat: dar al alamiya lil kitab, 2007), 211.

44 Anonymous informant (teacher), interview with author, June 2015.

45 In 1994, the Ministry of Human Rights reached an agreement with the Moroccan Ministry of Education to include a human rights curriculum. In 2004, a commission for human rights and citizenship took over the program to supervise its implementation in the Moroccan educational system.

46 Al jaded fi al ijtima'iyat, year 6 of elementary education (Rabat: Dar Nachr wal Maarifa, 2003).

47 The Moroccan Ministry of Education, National Education and Training Charter. http://www. men.gov.ma/Ar/Pages/charteEF.aspx (in Arabic), accessed March 12, 2017. 
1993, the Moroccan student is taught about his or her rights and duties as a member of society in terms of concepts such as equality, individual liberties, justice, solidarity, peace and religious tolerance, democracy, the rule of law, and human rights. In the eighth and ninth grades (Years 2 and 3 of middle school), the program also introduces the political system and state institutions of Morocco. It explains the roles of political parties as well as of unions and the press, yet without necessarily relating these to the sociopolitical issues of the country. For instance, when students are taught concepts such as illegal detention and political prisoners, no connection is drawn, at least not in the textbooks, to their systematic use by the Moroccan authorities in the past. ${ }^{48}$ As the educational system is based on a teacher-centered approach, learners are not encouraged to think critically about these concepts. ${ }^{49}$ Given the repressed memory of the past and the reluctance of the public media to deal with such topics, it is unlikely that students will draw their own connections.

"Citizenship and Human Rights Clubs" (HR clubs) were established with this idea in mind. By 2004, the civil society - represented by the Moroccan Association for Human Rights (AMDH), the Moroccan Organization for Human Rights $(\mathrm{OMDH})$, and Amnesty International in Morocco (AI) - reached an agreement with the Ministry of Education to provide students with workshops and opportunities to apply their human rights knowledge. To this end, the AMDH organized several training workshops for "social science" teachers (history, geography, and civic education) in order to equip them with the methods and educational tools appropriate for the teaching of human rights, children rights, and citizenship values. These were based on the universal concepts of human rights. Following these trainings, hundreds of participating educators decided to found HR clubs in their schools and train students and staff to run them. ${ }^{50}$

The effects of all this were enhanced by the National Education Emergency Programme designed by the Ministry of Education in 2009 to address the shortcomings of the 2002 reforms. The program established a commission of regional offices in the Ministry of Education to monitor and encourage gender equality in education and to provide a safe learning environment for students by fostering respect for human rights in public schools. Its objective was to create citizenship clubs and organize human rights events in all secondary schools in Morocco. In 2009, the state put in motion its 2006 national program for the

48 See, for example, An-Najah fi l-ijtima'iyat, Year 2 of Junior High (Casablanca: Imprimerie Najah al Jadida), 157-166.

49 On the challenges of civic education in Morocco, see Muhammad Faour, "A Review of Citizenship Education in Arab Nations," Carnegie Endowment for International Peace, 20 May, 2013. http://carnegieendowment.org/2013/05/20/review-of-citizenship-education-inarab-nations-pub-51771, accessed 12 March, 2017.

50 Abdelilah Ben Abdeslam, AMDH board member, interview with author, Rabat, 2015. 
"citizenship platform for the promotion of a culture of human rights" through education, awareness campaigns, and training. ${ }^{51}$ The $\mathrm{CNDH}$ joined efforts with other governmental institutions to organize activities and establish HR clubs in secondary schools, universities, vocational training colleges and youth clubs. $A l$ Wassit (the ombudsman of the country), the Royal Institute for Amazigh Culture (IRCAM), the University of Hassan II in Casablanca, and the Ministries of Education, the Interior, Justice, Communication, Islamic Affairs, and Youth, as well as non-governmental organizations $(\mathrm{AMDH}, \mathrm{OMDH}, \mathrm{Amnesty}$ Morocco, and others), were all involved in these initiatives. The AMDH, for instance, partnered with the Ministry of Education and held four training courses: Prometheus, Averroes, Amal, and Mashtal in September 2004, April 2005, October 2007, and April 2008. These benefited more than 2,000 students and 2,000 teachers from secondary schools, 5,400 students and 1,220 teachers from elementary schools, and 750 university students. Moreover, the AMDH has organized a series of 31 human rights summer camps in collaboration with the Ministry of Youth and Sports since 2003, which have seen the participation of over 5,000 young Moroccans. ${ }^{52}$

These workshops clearly aimed to raise awareness and educate Moroccans on liberal concepts of human rights. The AMDH hoped that the trainees would train other students and teachers, as well as translate their knowledge into attitudes that would impact the daily lives of Moroccans, thus disseminating the culture of human rights within the country. The Moroccan government, on the other hand, was obligated to fulfill the United Nations Millennium Development Goals (MDGs) it had endorsed since 1990 to reduce poverty, achieve universal primary education, and promote gender equality, among other objectives. ${ }^{53}$ By 2008 , the Ministry of Education was fiercely implementing the blueprint for education set by various UN agencies in order to meet the 2015 deadline. ${ }^{54}$ In the same year, the European Union granted Morocco an "Advanced Status" that translated into

$51 \mathrm{CNDH}$, "La plateforme citoyenne pour la promotion de la culture des droits de l'homme," http://www.cndh.org.ma/fr/plate-forme-citoyenne-pour-la-promotion-de-la-culture-desdroits-de-lhomme/la-plateforme-citoyenne, accessed July 12, 2017.

52 Association Marocaine de Droits Humains, Jami'at Ibn Rochd li tarbiya wa takwin ala huquq al insan (Rabat: manchurat tadamun, 2005); Association Marocaine de Droits Humains, Jami'at Ibn Rochd li tarbiya wa takwin ala huquq al insan (Rabat: manchurat tadamun, 2006); Association Marocaine de Droits Humains, Jami'at Ibn Rochd li tarbiya wa takwin ala huquq al insan (Rabat: matabi' al ribat, 2012).

53 On the MDGs, see the United Nations, "United Nations Millennium Development Goals," http://www.un.org/millenniumgoals/, accessed July 12, 2007.

54 Kingdom of Morocco, Morocco between Millennium Development Goals and Sustainable Development Goals: Achievements and Challenges (National Report, 2015). 
larger trade exchanges and significant funds with which the kingdom could invest in literacy, medical care, and other development projects. ${ }^{55}$

The Millennium Development Goals came as a response to various shortcomings of Moroccan education. As of 1999, high levels of illiteracy, premature school leaving, and graduate unemployment forced the Moroccan state to put in place a national strategy aligned with the MDGs to reform its educational system. The process was further spurred on by the European Union, which saw a growing number of minors illegally migrating to Europe, especially from the regions of Tangiers-Tetouan and Taza-Alhoceima-Taounate (the Rif). ${ }^{56}$ In a similar context to that which brought about the IER, pressures from international bodies such as the UN as well as local NGOs were able to push for more human rights-related content in textbooks and organize workshops and training around Human Rights Education (HRE). The Ministry of Education, as well as the CNDH, funded and promoted these new developments, primarily through "Human Rights Clubs" that flourished in secondary schools and universities thanks to the training and workshops provided, for example, by the AMDH.

However, neither students nor teachers in Moroccan schools pay civic education the attention it requires. Teachers do not always spend the sixty minutes per week nominally allocated to the subject actually teaching relevant material. When they do so, students are expected to learn concepts by heart solely for the purpose of examination, often without critical reflection. For this reason, citizenship and HR clubs were transformed into learning and training spaces for students and teachers alike. These clubs are usually run by volunteer staff and teachers from the school and involve members of local associations such as the $\mathrm{AMDH}$, the $\mathrm{OMDH}$ and Amnesty International in Morocco. Students are encouraged to be club leaders and board members, but this is not always possible due to student and teacher workloads. The clubs follow a participatory approach to learning methods and include activities such as roundtables, theatre, cinema, music, competitive sport, and visits to ministries and state institutions as well as human rights organizations. These are organized around concepts of human dignity, equality, accountability, democracy, freedom of expression, tolerance, solidarity, and other values. And because these activities are conducted outside a classroom setting centered on a teacher, students are encouraged to think critically about the meaning and application of human rights in a Moroccan context. This is even more the case when activities and discussions are facilitated by a

55 In 2008, the EU granted a total of 227.9 million euros of development aid. See for example UNICEF, The School of Respect: Reform, Participation and Innovation in Morocco's Education System (Learning Series, vol 3) https://www.unicef.org/mena/The_School_of_Respect-Enlow(1).pdf, accessed July 12, 2017.

56 Ibid. 
member of civil society and particularly by AMDH members, who do not shy away from discussing the heavy legacy of the "years of lead."

In a first period between 2005 and 2009, the CNDH sought to support human rights education for students and teachers in primary and secondary schools. Their training also targeted university students, professors, and staff, as well as civil servants and military officers. Since then, the CNDH has shown interest in the Citizenship and Human Rights Clubs and its regional offices have expanded upon their partnerships with the Ministry of Education and other civil-society actors involved in the clubs. The council also partnered with UNESCO and, in December 2015, published a Guide For Citizenship and Human Rights Education that "complied with the best practices and tools necessary for successful activities and the smooth running of an HR club." ${ }^{\text {"58 }}$ According to the publication, the toolkit was compiled in consultation with civil-society actors and HR clubs around the country in an attempt to standardize and facilitate the establishment of such clubs in schools across Morocco. Alongside both international and national human rights conventions, the guide also includes regulating laws, samples of action plans, monitoring and evaluation tools, partnership agreements, and funding sources to help students and teachers organize themselves. The $\mathrm{CNDH}$ has also produced a set of activities and events that HR clubs can arrange to cultivate citizenship skills and attitudes respectful of human rights, detailing the support and capacity-building provided by the $\mathrm{CNDH}$ regional offices for club members.

\section{Conclusion}

From a transitional justice perspective, education can further the achievements of measures such as truth commissions and memorialization initiatives when it clearly acknowledges the legacies of the past. Scholars and practitioners alike recommend teaching the findings of a TRC in schools in order to allow for counter-narratives to be discussed and to foster a dialogue within the classroom..$^{59}$ Without access to the IER archives, however, students who enrolled in the memory studies program Histoire du Temps Present were not able to engage in a genuine investigation of Morocco's violent past. The program itself was abandoned by the $\mathrm{CNDH}$, which diverted its funds to Human Rights Education (HRE) by supporting HR clubs and HR-related content in school textbooks. Yet

57 Rabia el Bouzidi, AMDH administrator, interview with author, June 2015.

$58 \mathrm{CNDH}$; Manuel de l'éducation à la citoyenneté et aux droits de l'Homme (Rabat, 2015).

59 See for example, Elizabeth A. Cole, "Transitional Justice and the Reform of History Education," International Journal of Transitional Justice, Vol. 1, No. 1 (March 2007). 
even when the official history curricula sketchily acknowledge the human rights abuses endured by Moroccans over four decades, Moroccan teachers still struggle to rid themselves of self-censorship and anxiety when addressing the past. As for HR clubs, almost six years after the launch of this initiative, many schools are struggling to maintain the interest of students and teachers. Omar Lamaallem, the principal of a high school in al Hoceima, notes that not all teachers have the time or the resources to invest in extra-curricular activities, and especially that schools in rural Morocco tend to lack teaching staff and funds as compared to educational institutions in the large cities such as Rabat or Casablanca. $^{60}$

Regardless of their actual impact and sustainability, the CNDH has promoted both initiatives as success stories representative of Morocco's democratic transition. As a result of the IER in its various phases (monetary compensation, investigations, public hearings, community reparations, and memorialization), the Moroccan regime considers the past closed. The $\mathrm{CNDH}$, the state institution responsible for the promotion and protection of human rights issues in the country, has shifted its focus to new matters that were deemed urgent by both the Moroccan state and the international community, notably poverty reduction, women's empowerment, and the fight against illegal immigration and terrorism. ${ }^{61}$

Thus, instead of broadening the debate around questions of justice, human rights, political accountability, and democracy, transitional justice in Morocco has rather allowed the regime to expunge from its present the massive human rights violations of the past, while perpetrators still hold office with total impunity. The monarchy in Morocco selected memorialization measures that would not compromise its legitimacy by pushing the crimes committed by the regime back into the past and only partially "exposing" them in the IER final report, in the cinema, in commemorative stones, and photobooks. The regime thus effectively removed the crimes from the present, declaring the past "confronted" and "the page of the Years of Lead turned," and attempts to commemorate victims in museums or memorial sites fell short of the envisaged objective. Had the former detention centers been converted into memorial spaces, visitors would have been able to re-live Morocco's violent past through what Eyal Weizman has called "forensic architecture." This concept refers to the possibility of imagining or reconstructing scenes of violence and torture in the locations where human rights and international law violations occurred, in-

60 Omar Lamaallem, interview with author, al Hoceima, June 2016.

61 These new concerns were repeatedly voiced by the president of the $\mathrm{CNDH}$ in an interview with the author, in various media outlets and are also reflected in the campaigns and reports by the $\mathrm{CNDH}$. 
cluding prisons and mass graves. ${ }^{62}$ Museums, especially those erected to commemorate a traumatic past, serve the purpose of translating past sufferings into material representations. ${ }^{63}$ In the same way, discussing the past in secondaryschool classrooms would have kept transitional justice narratives alive by celebrating the achievements of former political activists and inspiring the next generation to continue in their tradition.

In order to teach about the struggle of Mohand ben Abdelkrim el Khattabi in history textbooks, as called for by Hakim Benchemmas, quoted at the beginning of this chapter, teachers need to be able to break the wall of silence and explain to students the meaning of "turning the page on past abuses" when discussing, for example, the Instance Equité et Réconciliation. If the people of Morocco are to be proud of the founding of the Rif Republic in 1921, when the rest of Morocco was grappling with colonialism, education reforms in Morocco need to move forward and include the findings of the IER report in the classroom. The hope is that curriculum designers will be courageous enough to base their content on the latest and rather conservative publication of the Royal Institute for Research on the History of Morocco ${ }^{64}$ which openly discusses the "years of lead," albeit without naming perpetrators. A prerequisite for such a development, however, would be the decision by the state in general and the National Council for Human Rights (CNDH) to open up the IER archives to the public, and to genuinely implement the recommendations of its final report. Only when memory studies complement human rights teaching can education be an effective measure of transitional justice.

\section{Bibliography}

\section{List of textbooks cited}

Al Shamil fi al Tarikh. $2^{\text {nd }}$ year of high school. Casablanca: al Nashir al Atlassi, 2007.

Fada' al ijtima'iyat. $2^{\text {nd }}$ year of junior high, cycle préparatoire. Rabat: Imprimerie El Maarif, 2004.

Fi rihab tarikh. Year 2 of high school. Rabat: dar al alamiya lil kitab, 2007.

An-najah fi al-ijtima'iyat. Year 2 of junior high. Casablanca: Imprimerie Najah al Jadida, 2004.

Manar al ijtima'iyat. Year 3 of junior high. Casablanca: Top Editions, 2006.

62 Eyal Weizman in Slyomovics, "Inside the Inside: Life in Prison," Middle East Research and Information Project, No. 275. Vol. 45. No. 2 (Summer 2015), 30.

63 Slyomovics, "Inside the Inside: Life in Prison," 30.

64 Mohammed Kably (ed.), Histoire du Maroc: Réactualisation et Synthèse (Rabat: Institut Royal pour la Recherche sur l'Histoire du Maroc, 2011). 


\section{References}

Amnesty International. Les Disparus: Le mur du silence doit tomber. AI Index: MDE 29/01/ 93. April 1993.

Amnesty International. "Morocco/Western Sahara: New Arrests and Allegations of Torture of Sahrawi Human Rights Defenders." 26 August, 2005.

http://www.amnesty.org.au/news/comments/482/. Accessed June 12, 2017.

Association Marocaine de Droits Humains. Jami'at Ibn Rochd li tarbiya wa takwin ala huquq al insan. Rabat: manchurat tadamun, 2005.

Association Marocaine de Droits Humains. Jami'at Ibn Rochd li tarbiya wa takwin ala huquq al insan. Rabat: manchurat tadamun, 2006.

Association Marocaine de Droits Humains. Jami'at Ibn Rochd li tarbiya wa takwin ala huquq al insan. Rabat: matabi' al ribat, 2012.

CNDH. "Présentation du Programme IER2: Archives, Histoire Et Mémoire." http://www. cndh.ma/fr/programme-daccompagnement-aux-recommandations-de-lier-en-matie re-darchives-dhistoire-et-de-memoir-31. Accessed June 2016.

CNDH. L'enfermement et le partage: Lieux et mémoire, 2015. http://www.cndh.org.ma/fr/ ouvrages/lenfermement-et-le-partage-lieux-et-memoire. Accessed October 2017.

$\mathrm{CNDH}$. Signature d'une convention de partenariat entre le CCDH et l'université Mohammed V-Agdal sur la création d'un master d'histoire contemporaine. http://www. cndh.org.ma/fr/partenaires-nationaux/signature-dune-convention-de-partenariat-en tre-le-ccdh-et-luniversite-mohammed. Accessed June 12, 2017.

$\mathrm{CNDH}$. La plateforme citoyenne pour la promotion de la culture des droits de l'homme. http://www.cndh.org.ma/fr/plate-forme-citoyenne-pour-la-promotion-de-la-culturedes-droits-de-lhomme/la-plateforme-citoyenne. Accessed July 12, 2017.

CNDH. Manuel de l'éducation à la citoyenneté et aux droits de l'Homme. Rabat, 2015.

Cole, Elizabeth A. "Transitional Justice and the Reform of History Education." International Journal of Transitional Justice 1, no. 1 (2007): 115-137.

Faour, Muhammad. "A Review of Citizenship Education in Arab Nations." Carnegie Endowment for International Peace. 20 May 2013. http://carnegieendowment.org/2013/ 05/20/review-of-citizenship-education-in-arab-nations-pub-51771. Accessed March $12,2017$.

Hassani-Idrissi, Mostafa. "Manuels d'histoire et identité nationale au Maroc," Revue internationale d'éducation de Sèvres 69 (2015): 53-64.

Kably, Mohammed, ed. Histoire du Maroc: Réactualisation et Synthèse. Rabat: Institut Royal pour la Recherche sur l'Histoire du Maroc, 2011.

Miller, Susan G. A History of Modern Morocco. Cambridge: Cambridge University Press, 2013.

Ministry of Education (Morocco). National Education and Training Charter. http://www. men.gov.ma/Ar/Pages/charteEF.aspx (in Arabic). Accessed March 12, 2017.

Mouline, Nabil. "Reconsidering the Rif Revolt (1958-59)," in Jadaliyya. http://www.jada liyya.com/pages/index/20664/reconsidering-the-rif-revolt-(1958-59). Accessed 16 April, 2016.

Morocco, Kingdom of. Morocco between Millennium Development Goals and Sustainable Development Goals: Achievements and Challenges. National Report, 2015. 
Opgenhaffen, Veerle and Mark Freeman, Transitional Justice in Morocco: A Progress Report. New York: International Center for Transitional Justice, 2005.

Pennell, Richard C. A Country with a Government and a Flag: The Rif War in Morocco, 1921-1926. Wisbech: Middle East and North African Studies Press, 1986.

Pennell, Richard C. Morocco Since 1830: A History. New York: New York University Press, 2001.

Ramírez-Barat, Clara and Roger Duthie, Education and Transitional Justice: Opportunities and Challenges for Peacebuilding. New York: International Center for Transitional Justice and UNICEF, 2015.

Rollinde, Marguerite. Le Mouvement Marocain des Droits de l'Homme. Paris: Karthala, 2002.

Slyomovics, Susan. The Performance of Human Rights in Morocco. Philadelphia: University of Pennsylvania Press, 2005.

Slyomovics, Susan. Inside the Inside: Life in Prison. Middle East Research and Information Project 275 (45), no. 2 (2015).

UNICEF. The School of Respect: Reform, Participation and Innovation in Morocco's Education System. Learning Series. Vol.3. https://www.unicef.org/mena/The_School_of_ Respect-En-low(1).pdf. Accessed July 12, 2017.

United Nations. "United Nations Millennium Development Goals." http://www.un.org/ millenniumgoals/. Accessed July 12, 2007.

United States Institute of Peace. “Truth Commission: Morocco.” https://www.usip.org/ publications/2004/12/truth-commission-morocco. Accessed May 18, 2017.

Valensi, Lucette. "Le roi chronophage. La construction d'une conscience historique dans le Maroc postcolonial." Cahiers d'Études Africaines 30, no. 119 (Maghreb: récits, traces, oublis) (1990): 279-298. 


\title{
Education for Reconciliation: Transitional Justice in the Aftermath of Canada's Truth and Reconciliation Commission
}

\author{
It is precisely because education was the primary tool of oppression \\ of Aboriginal people, and miseducation of all Canadians, that we \\ have concluded that education holds the key to reconciliation. \\ - Justice Murray Sinclair ${ }^{1}$
}

Before beginning, I wish to address my own positionality as an exercise of the decolonizing methodologies I aspire to practice. ${ }^{2}$ I am a Romanian-born settler, who immigrated to Canada as a young girl, and neither myself nor my family have direct ties to the Indian Residential School system. This chapter is intended primarily to act as an introduction to the broader themes of education, decolonization, and the violence of settler colonialism in Canada. My undertaking here is to address, in fairly general terms, some of the core questions relating to these subjects. I do not mean to speak on the matter beyond providing context and introducing some of the leading Indigenous writers and scholars working within Canada today.

I first heard of residential schools when I was already fifteen years old and in my final years of high school. My social studies teacher sensed that his students were largely unaffected by the vagueness of the official curriculum when it came to the subject of colonialism. In fact, I often heard my classmates saying, "Canada has no history" or "Canadian history is boring."3 My teacher tried his best to

1 BC Teachers' Federation, "Education for reconciliation: BCTF launches new resource on residential school history in $\mathrm{BC}$," $\mathrm{BC}$ Teachers' Federation, https://bctf.ca/publications/Tea cherArticle.aspx?id=38000, accessed 30 April, 2016.

2 See Linda Tuhiwai Smith, Decolonizing Methodologies. Research and Indigenous People (New York: Zed Books, 2012) and Emma LaRocque, When the Other is Me. Native Resistance Discourse, 1850-1990 (Manitoba: University of Manitoba Press, 2010).

3 For many years, schoolteachers across Canada have relied on showing their students short videos known as "Heritage Minutes"; these videos were regarded as comical, outdated and overdramatic by my classmates. However, since the TRC, new "Heritage Minutes" have been made with the purpose of educating students on Canada's colonial history. These are more artful in execution as well as significantly less racist in their content. These educational videos are made by the non-profit organization Historica Canada, whose mandate is "enhancing awareness of Canadian history and the values of Canadian citizenship"; in June 2016, the organization finally released a video on the Indian Residential School system, written by an Indigenous novelist: "New Heritage Minute explores dark history of Indian residential 
draw our attention to Indigenous politics, knowing that the limited and "apolitical" presentation of information through classroom materials largely prevented us from connecting to the history itself. I remember that my teacher invited his Indigenous friend to come in and speak to our class about the negative impact of state policy upon his life, describing his frustrations with the Canadian government, particularly concerning the reality of having/not having Indian status. ${ }^{4}$ I looked back on the stories told by my teacher's friend for many years and, certainly, my teacher's efforts are to be commended; he tried his best to teach us about the darker chapter of Canadian history, while keeping our lessons immersive and creative (one of our largest projects, for instance, was to draw our very own comic book about Louis Riel). ${ }^{5}$ However, when I reached university I still had an incomplete understanding of the circumstances that had allowed for the Indian Residential School system or the Indian Act of 1876. I became angrier as I put the pieces together (a slow process over several years) and began to comprehend that Canada (by which I mean the Canadian State and its institutions) had purposefully - and successfully - concealed a history of genocide from me for most of my life. It was only in my final years of university (and largely because of my own interest and insistence) that I learned more extensively about the colonial violence so central to Canada's past and present. Billy-Ray Belcourt asks a question that powerfully pinpoints the responsibility of the Canadian government of the day to the legacy of colonialism: "What of the deeply stubborn traces of a governmental enterprise that lawfully desired our elimination, that corralled and still corals Indigenous peoples in prisons and cemeteries in order to disappear us and the ancient legal and political orders hidden in our breathing?"6

Once I had gained a better understanding of the roots of discrimination against Indigenous peoples, I felt ashamed of being complicit in colonial violence for most of my life. I continue to feel this shame (settler-shame) and the obligation to confront this subject in my research as a means of reflecting on my own

schools," CBC News, 21 June, 2016: http://www.cbc.ca/news/aboriginal/new-heritage-minuteexplores-dark-history-of-indian-residential-schools-1.3643363, accessed 21 June, 2016.

4 The Indian Act of 1876 is a federal law that governs a variety of matters concerning Indian status, bands, and Indian reserves in Canada. The Indian Act enabled (and continues to enable) the government to define who qualifies as "Indian" or of "Indian status." Not all Indigenous peoples are recognized as being "status Indians" in Canada; for instance, the Métis and Inuit are excluded. For more information, see: "The Indian Act," Indigenous Foundations (University of British Columbia), http://indigenousfoundations.arts.ubc.ca/home/govern ment-policy/the-indian-act.html, accessed 30 April, 2016.

5 Louis Riel was a Métis politician who led a number of resistance movements against the Canadian government. He is a popular and well-known Indigenous historical figure.

6 Billy-Ray Belcourt, "The day of the TRC Final Report: On being in this world without wanting it," The Rabble, 15 December, 2015, http://rabble.ca/news/2015/12/day-trc-final-report-onbeing-this-world-without-wanting-it, accessed 30 April, 2016. 
role and taking responsibility as a trespasser living here today. ${ }^{7} \mathrm{I}$ believe that the more education there is about Canada's history, the more possible it becomes for settlers to follow Indigenous leadership and dismantle the systems of violence existing in Canada today. Ultimately, I am choosing to write on this subject matter not as a voice of authority. Rather, I hope that (in a post-Truth and Reconciliation Canada) all students are better educated on the historical relationships between Indigenous peoples and colonizers and at an earlier age than I was. An education grounded in a better understanding of a shared history makes it possible for young students to understand the necessity in decolonizing Canada's present systems and structures. Finally, I strongly believe that it is Canada's youth (both Indigenous and non-Indigenous) who hold the power to alter, improve and repair our divided society and that the quality of education they receive on this topic is, therefore, a priority. ${ }^{8}$

\section{Introduction}

This chapter examines the relationship between education and transitional justice in the aftermath of Canada's Truth and Reconciliation Commission (hereafter referred to just as TRC). While knowledge is generally understood as being acquired through some form of education, in the case of Canada, valuable knowledge was actually eradicated by colonial policy and the nation-wide, statesanctioned Indian Residential School (IRS) system, which deemed Indigenous languages and teachings to be both inferior and unimportant. In Canada, education was systematically used between 1870 and 1996 as a means to harm Indigenous bodies and Indigenous cultures en masse. Within this chapter, I introduce Canada's history of colonialism and use it to reflect on how education can and actually has been used for genocidal purposes, arguing that traditional transitional justice measures do not necessarily fit with Canada's case, where the "conflict" is "non-traditional" for having spanned hundreds of years.

After recognizing some of the limitations of the TRC, the objective of this chapter is to, instead, emphasize innovative, successful, and localized examples

7 I elaborate more on settler-shame in my Master's thesis: Stefana Fratila, "Decolonizing Reconciliation: Refusing Settler Innocence Through Sound," University of British Columbia, https://open.library.ubc.ca/cIRcle/collections/ubctheses/24/items/1.0228649, accessed 30 April, 2016.

8 I am very grateful to have had the opportunity to study traditional, ancestral, unceded and occupied $\mathrm{x}^{\mathrm{w}} \mathrm{m} \partial \mathrm{k}^{\mathrm{w}}$ əýəm (Musquem) territories for my Master's in Political Science at the University of British Columbia. I want to thank Glen Coulthard, Steven Hill, Lindsay Lachance, Sheryl Lightfoot and Deneh Thompson for many enlightening conversations and their generous guidance around this topic. I also want to thank Erin Baines, Alison James, Clara Ramírez-Barat, and Martina Schulze for their ongoing support with this chapter. 
of educational initiatives that meaningfully teach Indigenous peoples and settlers alike about their shared history. My research focuses on the ways in which instructors, students, and community members have memorialized experiences of colonial violence and settler colonialism, and presents the potential for these learning experiences to create space for meaningful knowledge-sharing, memorialization, social transformation, and, eventually, decolonization. If we accept, as I do here, that it is not education but colonialism that has been (and continues to be) the problem in Canada, then the task remains not to correct but to "decolonize" education itself. I argue that education in post-TRC Canada must move beyond the mere inclusion of content on the IRS past and encourage selfreflexivity in students. It is integral to provide non-Indigenous students with pathways towards taking responsibility for their roles as settlers so that they learn to listen and follow their Indigenous counterparts, whether classmates, community members, or Indigenous learnings and pedagogy more widely. In order to enact change, all students must be taught to recognize as well as understand how colonialism still plays out around them.

Taking this position into account, the chapter centers on three initiatives that seek to decolonize education: first, changes in the elementary-level curriculum following the TRC; secondly, Dechinta, an Indigenous-led school in the north grounded in Indigenous teachings and a land-based approach; and finally, a 2015 production of the play, The Unnatural and Accidental Women, about the lives of Indigenous women murdered in Vancouver's Downtown Eastside (DTES) and whose deaths were never adequately investigated or acknowledged, led by an Indigenous dramaturge and performed by an all-settler student cast. In my writing, I am using the concepts of decolonization and Indigenization based on specific definitions and a particular understanding of these words. Karlene Harvey, an Indigenous academic advisor at the University of British Columbia (UBC), explains that decolonization identifies the systematic barriers in changing systems while Indigenization relates to incorporating more indigeneity in institutions (for example, hiring more Indigenous teachers and professors, or taking in more Indigenous students). ${ }^{9}$

9 Emi Sasagawa, "Workshop explores ways of supporting Indigenous students at UBC," UBC, 16 May, 2016, http://aboriginal.ubc.ca/2016/05/16/workshop-explores-ways-of-supportingindigenous-students-at-ubc/, accessed 30 May, 2016. 


\section{The Indian Residential School System: "Kill the Indian"}

In the summer of 2015, Canada's Truth and Reconciliation Commission released its final report, Honouring The Truth, Reconciling for the Future. Widely anticipated across Canada, it begins: "Canada's residential school system for Aboriginal children was an education system in name only," adding that residential schools were created "for the purpose of separating Aboriginal children from their families, in order to minimize and weaken family ties and cultural linkages, and to indoctrinate children." 10 The TRC report goes on to inform readers that residential schools date back as early as $1870 .{ }^{11}$ The last closed only relatively recently in 1996 - all in all, residential schools were open for well over one hundred years. ${ }^{12}$

What was the purpose of the IRS system? The language used by one Reverend in 1938 was that it was only through residential schools that the "Indian problem" in Canada could be "solved." 13 The TRC report states that Canada "wished to divest itself of its legal and financial obligations" to Indigenous people and "gain control over their lands and resources." 14 We are speaking of 130 government-funded and church-run schools with the stated explicit purpose to "kill the Indian" and "save the man" in each child. ${ }^{15}$ Ronald Niezen observes that Indigenous children were "especially vulnerable" because the "ultimate goal behind their incarceration in school was that of correcting the essence of their being." ${ }^{16}$ Over 150,000 Indigenous children were taken by force (often violently) from their families and placed in residential schools across Canada, where they would be far away from their homes and not allowed to see their parents. ${ }^{17}$ They were forbidden to speak their own languages - the significance of this perhaps

10 Truth and Reconciliation Commission of Canada, Honouring the Truth, Reconciling for the Future, Summary of The Final Report of the Truth and Reconciliation Commission of Canada (Montreal and Kingston: Truth and Reconciliation Commission of Canada, 2015), v.

11 Truth and Reconciliation Commission, "Canada's Residential Schools: The History, Part 1, Origins to 1939," The Final Report of the Truth and Reconciliation Commission of Canada, 6 volumes (Winnipeg: Truth and Reconciliation Commission of Canada, 2015), vol. 1, Part 1, 4.

12 CBC News, "A Timeline of Residential Schools: The Truth and Reconciliation Commission," CBC News, 25 March 2014, http://www.cbc.ca/news/canada/a-timeline-of-residentialschools-the-truth-and-reconciliation-commission-1.724434, accessed 30 April, 2016.

13 Mark Cherrington, “Oh, Canada!” Cultural Survival, Fall 2007, https://www.culturalsurvival. org/publications/cultural-survival-quarterly/canada/oh-canada, accessed 30 April, 2016.

14 Truth and Reconciliation Commission, "Honouring the Truth, Reconciling for the Future," 3.

15 Truth and Reconciliation Commission, "Canada's Residential Schools: The History, Part 1 Origins to $1939, " 137$.

16 Ronald Niezen, Truth \& Indignation: Canada's Truth and Reconciliation Commission on Indian Residential Schools (Toronto: University of Toronto Press, 2014), 26-27, emphasis added.

17 Truth and Reconciliation Commission, "Honouring the Truth, Reconciling for the Future," 2. 
better understood when we consider that there are over sixty Indigenous languages from twelve distinct language families. ${ }^{18}$ For these reasons, the TRC concluded that Canada had committed "cultural" genocide and recommended that the Canadian government do its part in preserving Indigenous languages and integrating Indigenous teachings into the country's education systems. ${ }^{19}$ According to Onowa McIvor, director of Indigenous education at the University of Victoria, recommendations like these had already been made by Indigenous leaders multiple times for decades prior to the TRC. ${ }^{20}$

Currently, there are an estimated 80,000 survivors of the residential school system, of varying ages. ${ }^{21}$ Many of the students suffered serious emotional, physical, and sexual abuse. Abusers were sheltered by the institutions in which they worked and children were essentially put into the care of those whose authority went "virtually unquestioned."22 In some cases, medical experiments were performed. ${ }^{23}$ Several women were sterilized, numerous others died while attending these schools, and in many cases families were not informed of their children's illnesses or deaths. ${ }^{24}$ It was also common for their age, gender, or cause of death to go unrecorded and their graves to be unmarked. ${ }^{25}$ The TRC was unable to ascertain the exact number of children who died in the schools. Justice Murray Sinclair, who headed the TRC, suggested that the government stop recording deaths because the number was too high ${ }^{26}$ Regardless, the deaths of

18 Ali Point West, "Aboriginal languages in Canada can and should be made official, expert says," CBC News, 11 July 2015, http://www.cbc.ca/news/canada/british-columbia/aboriginallanguages-in-canada-can-and-should-be-made-official-expert-says-1.3147759, accessed 30 April, 2016.

19 Truth and Reconciliation Commission, Truth and Reconciliation Commission: Calls to Action (Winnipeg, Truth and Reconciliation Commission, 2015), 2.

20 Ali Point West, "Aboriginal languages in Canada."

21 Truth and Reconciliation Commission, "Honouring the Truth, Reconciling for the Future," 370.

22 Ronald Niezen, Truth \& Indignation, 26.

23 Truth and Reconciliation Commission, "Canada's Residential Schools: The History, Part 2, 1939 to 2000," The Final Report of the Truth and Reconciliation Commission of Canada, 6 volumes (Winnipeg: Truth and Reconciliation Commission of Canada, 2015), vol. 1, Part 2, 285.

24 Truth and Reconciliation Commission of Canada, Survivors Speak, (Winnipeg: Truth and Reconciliation Commission of Canada, 2015), vii.

25 APTN, "Number of Indian residential school student deaths may never be known: TRC," APTN National News, 2 June, 2015, http://aptn.ca/news/2015/06/02/number-indian-res idential-school-student-deaths-may-never-known-trc/, accessed 30 April, 2016.

26 Chinta Puxley, "Feds stopped keeping track of children who died in residential schools 'probably because rates were so high'," National Post, 31 May, 2015, http://news.nationalpost. com/news/canada/feds-stopped-keeping-track-of-children-who-died-in-residential-schoolsprobably-because-rates-were-so-high, accessed 30 April, 2016. 
many children were recorded, and the number is catastrophically high; the TRC reported finding at least 6,000 deaths as a result of the IRS system. ${ }^{27}$

Some children died from the poor living conditions, while others died trying to escape the schools. The Canadian Broadcast Company $(\mathrm{CBC})$, reported the statistic that the odds of dying for Canadians serving in WWII was one in twentysix while the odds of dying for children in residential schools was one in twentyfive. ${ }^{28}$ This is telling of the conditions of violence in these schools. Ultimately, Indigenous children were not treated humanely and their experiences in residential schools have resulted in serious intergenerational trauma, leading to survivors and their families identifying themselves as Intergenerational Survivors. ${ }^{29}$ The IRS system has impacted multiple generations of Indigenous peoples. As Niezen notes, “The subject of Indian residential schools doesn't easily let go once it has gotten hold." 30

If we consider that the IRS system began in the late 1800 s, the implementation of the TRC was a long time coming. The Canadian government avoided addressing the legacy of the IRS system for many years, thus contributing to the perpetuation of severe addiction problems and domestic violence within (often isolated) reserve communities. Furthermore, underlying gender-based violence in government policy went ignored. For years, Indigenous women and their children were denied "Indian status" in order to discourage interracial marriage; an Indigenous woman would thus lose her status if she married a non-Indigenous man, or her status would not be passed on to her children (whereas these policies were not applied to Indigenous men). Indigenous writers like Leanne Betasamosake Simpson note that the Canadian government's policies led to matriarchal societies being torn apart and reorganized along colonial and patriarchal lines. ${ }^{31}$ These deeply-rooted harms have not been undone in Canada; the following section elaborates upon the connection between ongoing colonial violence and the work of the TRC.

27 APTN, "Number of Indian residential school student deaths may never be known: TRC."

28 Daniel Schwartz, "Truth and Reconciliation Commission: By the numbers," CBC News, 2 June, 2015, http://www.cbc.ca/news/aboriginal/truth-and-reconciliation-commission-bythe-numbers-1.3096185, accessed 30 April, 2016.

29 Truth and Reconciliation Commission of Canada, Survivors Speak, 12.

30 Ronald Niezen, Truth \& Indignation, xi.

31 See Leanne Betasamosake Simpson, "Queering Resurgence: Taking On Heteropatriarchy In Indigenous Nation Building,” 1 June, 2012, http://leannesimpson.ca/queering-resurgencetaking-on-heteropatriarchy-in-indigenous-nation-building/, accessed 30 April, 2016. 


\section{The TRC: Six Years and Over Six Thousand Witnesses}

Over the course of nearly 900 events organized all over the country, Canada's TRC was convened between 2008 and 2015 with the primary mandate to "educate the public about the legacy of residential schools." 32 These events served the explicit purpose of engaging and educating the general public about the history of the IRS system, the experiences of former students and their families, and the ongoing legacies within Indigenous communities. The events also aimed to provide opportunities to celebrate cultural diversity and to honor those affected by the IRS system. It is important to note that the TRC was established under the terms of the Indian Residential Schools Settlement Agreement (IRSSA), meaning it was created as a result of survivors speaking out about their experiences within residential schools in a legal forum. Mi'kmaq lawyer Pamela Palmater writes that the TRC's mandate was a result of the litigation and subsequent settlement by survivors who wanted Canadians to have "a true understanding of what happened in those schools." 33

Some scholars understand the TRC as being oriented towards surviving witnesses with the need to share their stories, in other words, survivors who for many years had not been given a voice. ${ }^{34}$ Ronald Niezen elaborates on this, adding that survivors also shared other needs: the need for "support" and "affirmation" with their psychological pain, as well as the need to "complete a transition in the emotional composition of their identities." Here, Niezen is referring specifically to the shame that follows sexual abuse and the transition to "personal and collective esteem." "35 One of the TRC reports, entitled Survivors Speak, offers numerous accounts of how residential schools did great harm and indeed the very opposite of educating students. One survivor, Elaine Durocher, states: "They were there to discipline you, teach you, beat you, rape you, molest you, but I never got an education. I knew how to run." 36

The TRC heard from over 6,000 witnesses over the course of six years, most of whom had survived the residential schools as students. ${ }^{37}$ Since the TRC was largely structured to hear from these witnesses, its events generally revolved

32 Truth and Reconciliation Commission, "Honouring the Truth, Reconciling for the Future," 32.

33 Pamela D. Palmater, “Canada's residential schools weren't killing culture, they were killing Indians," The Rabble, 9 June, 2015, http://rabble.ca/blogs/bloggers/pamela-palmater/2015/ 06/canadas-residential-schools-werent-killing-culture-they-were, accessed 30 April, 2016.

34 Niezen, Truth \& Indignation, 95-96.

35 Ibid.

36 Truth and Reconciliation Commission of Canada, Survivors Speak, 120. TRC, AVS, Elaine Durocher, Statement to the Truth and Reconciliation Commission of Canada, Winnipeg, Manitoba, 16 June 2010, Statement Number: 02-MB-16JU10-059.

37 Truth and Reconciliation Commission, "Honouring the Truth, Reconciling for the Future," v. 
around the relationship between giving testimony and bearing witness; that is, Indigenous survivors giving testimony and settlers bearing witness to these testimonies. Collecting stories and providing survivors with a forum in which to share their experiences is absolutely important and admirable work, and the TRC was successful in many ways in this regard. However, in educating on narratives largely imbued within the past, the parameters of the TRC were limited to a space comfortable for present-day colonial systems and structures. Instead of focusing on how the legacy of residential schools informs present-day discrimination and the imbalance of privilege between Indigenous and nonIndigenous peoples, the TRC focused on the need for healing within both Indigenous persons as well as Indigenous communities at large. This focus on healing made it unlikely that settlers would face the fact of their compliance and their own responsibilities to Indigenous peoples and communities, directing the duty to Indigenous peoples instead. As Dene scholar Glen Coulthard aptly puts it, Indigenous subjects were "the primary object of repair, not the colonial relationship." 38

\section{Decolonizing Reconciliation: "Nontransitional" Circumstances}

While the TRC reports do (at one point) state that no process of reconciliation or decolonization can take place without "first recognizing and addressing the legacy of colonialism," 39 the TRC's methods and understanding of "decolonization" remain fixated on the past. The aforementioned "legacy" is understood through the lens of "bearing witness" to past wrongs and therefore does not address the implications of these past wrongs for the present. In other words, colonial violence of the past is not actively connected to issues and injustices considered most pertinent today by Indigenous peoples in Canada. That incarceration rates are rising disproportionately for Indigenous women, that many Indigenous communities are without clean water, or that Indigenous women and girls disproportionately go missing and are murdered, are all facts which are neglected or ignored by the TRC reports and yet these are all examples of the kind of racism that exists in Canada. While the TRC does recommend an inquiry into the cases of missing and murdered Indigenous women and girls, it does not provide any analysis to explain the connection between colonialism and the disproportionate violence against them. Nor do the TRC reports adequately

38 Glen Coulthard, Red Skin, White Masks: Rejecting the Colonial Politics of Recognition (Minneapolis: University of Minnesota Press, 2014), 127.

39 Truth and Reconciliation Commission, "Canada's Residential Schools: The History, Part 1. Origins to $1939, " 24$. 
stress the fact that there are more Indigenous children in government care now than during the residential school era: between 30,000 and 40,000 Indigenous children are in state care today. ${ }^{40}$ The lack of context around current-day statistics and violence in combination with the TRC's (aforementioned) focus on settler witnessing and Indigenous healing allows settlers to remain comfortable in a space of "innocence."

Since the current Canadian government is not "directly" responsible for the IRS system, the crimes of that system (and colonialism in itself) remain imprinted in the past. This is especially significant when we consider former Prime Minister Stephen Harper candidly claiming that Canada has "no history" of colonialism only a year after his 2008 apology for the IRS system. ${ }^{41}$ This is indicative of a system wherein non-Indigenous people are unable to draw connections, see patterns, or accept responsibility for their roles as colonizers/ settlers/trespassers. This circumstance brings forward questions about what transitional justice can contribute in cases where recent violence has to be explained against the backdrop of years of injustice. In Canada, colonial violence has taken place across a time-span of hundreds of years, whereas most TRCs have, so far, addressed violence (usually in the form of human rights abuses) spanning far shorter periods of time. The majority of the perpetrators (and in some cases their descendants) are no longer alive, and the legacy of their crimes is deeply connected to ongoing violence experienced by Indigenous peoples today.

It is critical to understand that the kind of violence Indigenous peoples in Canada have experienced does not completely match the shape of "transitional justice" circumstances and descriptions as we have generally defined them. There is no real way to identify a "pre-" or "post-" to colonial bloodshed as violence against Indigenous peoples still exists en masse (statistics show) and is, therefore, still endemic in Canada today just as it existed until 1996 when the last residential school closed. Furthermore, since most residential schools had closed by the 1960 s, crimes against Indigenous bodies have been generally understood as belonging to a time that has "passed." The problem is therefore twofold: the formal "end" of the IRS system does not mean the end of colonial violence, and settlers have long been miseducated or uneducated around the history of colonialism in Canada. In other words, it becomes difficult to discuss "reconciliation" when the relevant conflict is still very much ongoing.

Terms like "post-conflict" or "peacebuilding" cannot be applied in this con-

40 Palmater, "Canada's residential schools weren't killing culture, they were killing Indians."

41 Derrick O'Keefe, "Harper in denial at G20: Canada has 'no history of colonialism'," The Rabble, 28 September, 2009. http://rabble.ca/blogs/bloggers/derrick/2009/09/harper-denialg20-canada-has-no-history-colonialism, accessed 30 April, 2016. 
text of damage over hundreds of years of (ongoing) colonialism around and beyond the IRS system. Glen Coulthard argues that we are living in "nontransitional circumstances," adding that in "such conditions, reconciliation takes on a temporal character as the individual and collective process of overcoming the subsequent legacy of past abuse, not the abusive colonial structure itself." ${ }^{42}$ In other words, while the settler-colonial state remains intact and colonialism and capitalism continue to be intertwined, the circumstances themselves are not in transition and justice is not served. Coulthard also notes that, in the context of settler colonialism, there is "no period marking a clear or formal transition from an authoritarian past to a democratic present." ${ }^{\prime 43}$ It therefore becomes difficult to navigate concepts such as "forgiveness" when the systems and structures remain so very alive, felt by all Indigenous persons in Canada in their everyday lives.

The major limitation of the TRC was that it sought to apply a transitional justice formula upon a society that is not in transition per se. In other words, through its focus on settler-witnessing and Indigenous healing, the TRC historicized colonial violence - incorrectly - as something of the past, which many have argued made a spectacle of Indigenous trauma. ${ }^{44}$

\section{"Cultural" Genocide on Native Land}

Ten years prior to the TRC, Australian settler anthropologist Patrick Wolfe stated that the "question of genocide" is "never far from discussions of settler colonialism." ${ }^{45}$ Admittedly, perhaps one of the most controversial issues surrounding Canada's TRC is the affirmation that the Canadian government committed "cultural" genocide. The TRC defined this term as "the destruction of those structures and practices that allow the group to continue as a group," marking distinctions between cultural, physical, and biological genocide. ${ }^{46}$ However, the choice to describe the IRS system as "cultural" genocide has been widely critiqued. Writer Jesse Staniforth states that the word "cultural" is a "civilizing adjective" that implies the "policies were not truly evil, just deeply misguided," reminding readers that Indigenous children were in fact "submitted" to a program of forced labour, left to a system of education "designed to destroy" In-

42 Glen Coulthard, Red Skin White Masks, 108.

43 Ibid.

44 See Glen Coulthard, Red Skin, White Masks: Rejecting the Colonial Politics of Recognition; and Simpson, Dancing on our Turtle's Backs.

45 Patrick Wolfe, "Settler Colonialism and the Elimination of the Native," Journal of Genocide Research 8, no. 4 (2006): 387.

46 Truth and Reconciliation Commission, "Honouring the Truth, Reconciling for the Future," 1. 
digenous cultures and civilizations. ${ }^{47}$ Furthermore, an op-ed penned by Pamela Palmater states: "Canada didn't forcibly sterilize Indigenous women and girls without their consent to stop them from speaking their languages - they did it to eliminate the population," adding that, according to the United Nations (UN) definition, "that is genocide." 48 When it comes to Canada's history, therefore, we really are speaking about a system of "education" used for genocidal purposes; a system that was designed so as to ensure the widespread assimilation and destruction of Indigenous languages and cultures, and that ultimately led to a horrific outcome: the deaths of thousands of Indigenous children while in the "care" of the state's "education" system.

There is a section within the TRC reports that explains how the term "cultural" genocide came into use. Although the term is not found in the UNConvention on Genocide, the report argues that the articles within the Convention include actions outside the "immediate physical destruction" of a group of people. ${ }^{49}$ The reports acknowledge that both Canada's forcible sterilization of Indigenous women/girls and the removal of Indigenous children from their families and homes were destructive in nature, yet they conclude that because women, girls, and children were ultimately "allowed" to live, the IRS system does not constitute genocide in terms with which we are familiar. Rather, the reports add the civilizing term of "cultural" to the word expressing the most unspeakable act known to human life. ${ }^{50}$ Moreover, there is only one mention of the word "sterilization" in the entirety of the TRC reports and it is brought up only in the context of an explanation of the term cultural genocide.

Ultimately, any conversation regarding cultural genocide must take into account that history with a capital " $\mathrm{H}$ " has long been critiqued by Indigenous peoples. Scholars such as Linda Tuhiwai Smith speak to this point in a variety of ways in her seminal book, Decolonizing Methodologies: Research and Indigenous Peoples, arguing that Indigenous peoples have protested settler colonialism from the beginning, contesting settler narratives through their weavings, carvings and even within the names people carried, all in a country where Indigenous peoples were forced to learn new names for their own lands. ${ }^{51}$ This aspect about land is critical because, in the aftermath of the TRC, the most pertinent question really

47 Jesse Staniforth, “Cultural genocide’? No, Canada committed regular genocide," Toronto Star, 10 June, 2015, https://www.thestar.com/opinion/commentary/2015/06/10/cultural-gen ocide-no-canada-committed-regular-genocide.html, accessed 30 April, 2016.

48 Palmater, "Canada's residential schools weren't killing culture, they were killing Indians," emphasis added.

49 Truth and Reconciliation Commission, "Canada's Residential Schools: The Legacy," The Final Report of the Truth and Reconciliation Commission of Canada, 6 volumes (Winnipeg: Truth and Reconciliation Commission of Canada, 2015), vol. 5, 125.

50 Ibid.

51 Smith, Decolonizing Methodologies, 34. 
is: Why are settlers unwilling to recognize patterns of ongoing colonialism? The answer: Because it means giving land back.

The return of land ultimately weighs upon any analysis of the TRC, its successes, or failures. No land was returned, nor was the returning of land ever a matter of debate for the TRC. Yet for many Indigenous peoples, "reconciliation" is intrinsically tied to regaining sovereign power over land that is rightfully theirs. This seems highly relevant when we consider how reparations are a transitional justice mechanism. Should not the returning of land have been a form of reparation in the case of Canada? Smith states that Indigenous peoples "are not the final arbiters of what really counts as the truth"; this, too, is an important reaffirmation and insight for the work of the TRC, wherein History is also about power. ${ }^{52}$ Perhaps it is apt to also apply this line of thinking to our understanding of truth and, certainly, to the ever-loaded word reconciliation in the context of the TRC in Canada, where truth and reconciliation are, ultimately, also about power.

However we may interpret the (loaded) " $R$ " word, it is clear that reconciliation takes time. Leanne Betasamosake Simpson, writer and scholar of Michi Saagiig Nishnaabeg ancestry, speaks of reconciliation as a process of regeneration, stating:

For reconciliation to be meaningful to Indigenous Peoples and for it to be a decolonizing force, it must be interpreted broadly. To me, reconciliation must be grounded in cultural generation and political resurgence. It must support Indigenous nations in regenerating our languages, our oral cultures, our traditions of governance and everything else residential schools attacked and attempted to obliterate ... Canada must engage in a decolonization project and a re-education project that would enable its government and its citizens to engage with Indigenous Peoples in a just and honourable way in the future..$^{53}$

\section{Indigenous Education and Indigenizing Education}

Indigenous language, culture, and teachings have a critical role to play in the future of Canada's education system, particularly because of the extensive violence of the IRS system. Both the teaching of Indigenous history and the integration of Indigenous teachings are included in the calls to action of the TRC. ${ }^{54}$

52 Ibid., 34.

53 Leanne Betasamosake Simpson, Dancing On Our Turtle's Backs: Stories of Nishnaabeg Recreation, Resurgence, and A New Emergence (Winnipeg: ARP Books, 2011), 22-23, emphasis added.

54 See "Education for Reconciliation": Truth and Reconciliation Commission, "Calls to Action," 7. 
After all, it is state-sanctioned assimilation tactics that separated multiple generations of Indigenous children from their language, culture, and teachings; in other words, their sense of identity. Since the TRC, the restoration of Indigenous language, culture, and teachings has been discussed widely across Canada. There has been a move to "Indigenize" universities by implementing mandatory Indigenous Studies courses. Although universities which have made curricular changes have received positive attention from the media, important critiques have been made regarding mandatory courses, including the over-burdening of the already under-represented Indigenous professors across Canadian campuses. ${ }^{55}$ Nevertheless, the conversation is taking place, and current Prime Minister Justin Trudeau has even stated that restoring Indigenous languages is "key" to preventing suicide amongst Indigenous youth. ${ }^{56}$

The relationship between education and Indigenous identity is an important one. In British Columbia, the First Nations Education Steering Committee (FNESC) is a permanent organization that advocates for the education of First Nations children. ${ }^{57}$ FNESC aims to reinstil a sense of identity in Indigenous children; Tyrone McNeil, the organization's president, remarks, "too many of our people have been removed over multiple generations from who they are and how they're relating to the land. ${ }^{158}$ Founded in 1992, the FNESC has outlined nine First Peoples Principles of Learning, which "reflect a respectful and holistic approach to teaching and learning":

Learning ultimately supports the well-being of the self, the family, the community, the land, the spirits and the ancestors.

Learning is holistic, reflexive, experiential and relational (focused on connectedness, on reciprocal relationships and a sense of place).

Learning involves recognizing the consequences of one's actions.

Learning involves generational roles and responsibilities.

Learning recognizes the role of Indigenous knowledge.

Learning is embedded in memory, history and story.

Learning involves patience and time.

Learning requires exploration of one's identity.

55 See: Daniel Heath Justice, 21 November, 2015, https://www.facebook.com/daniel.justice. 7393/posts/535094576666580, accessed 30 June, 2016.

56 Chinta Puxley, "Restoring indigenous languages, key to preventing youth suicides, Trudeau says," Toronto Star, 3 June, 2016, https://www.thestar.com/news/canada/2016/06/03/res toring-indigenous-languages-key-to-preventing-youth-suicides-trudeau-says.html, accessed 30 June, 2016.

57 First Nations Education Steering Committee, “About FNESC," FNESC, http://www.fnesc.ca/ about-fnesc, accessed 30 April, 2016.

58 FNESC and FNSA, "The British Columbia First Nations Education System," Vimeo, https:// vimeo.com/44493997, accessed 30 April, 2016. 
Learning involves recognizing that some knowledge is sacred and only shared with permission and/or in certain situations. ${ }^{59}$

FNESC is an organization that demonstrates renewed control over the kind of education that Indigenous children receive, as well as controlling how Indigenous teachings are portrayed and understood by other institutions (including state-funded education systems across Canada). Soon after the TRC ended, provincial governments across Canada announced that young children would begin learning about residential schools as well as other discriminatory government practices, and educators across the country began developing resource guides in order to implement the TRC's recommendations. These measures include children's books that reflect on the experience of residential schools in an age-appropriate manner. ${ }^{60}$

The well-known organization Project of Heart has been working towards engaging young students with these difficult topics. The organization is a national, elementary and secondary-school level art-based educational initiative that commemorates the lives of Indigenous persons who underwent the IRS system. According to their website, "Project of Heart' is an inquiry based, hands-on, collaborative, inter-generational, artistic journey of seeking truth about the history of Aboriginal people in Canada." ${ }^{61}$ Both FNESC and Project of Heart recently recognized 10 books on residential schools as "age-appropriate" for children under $12 .^{62}$ The new curriculum is said to be integrating Indigenous history, culture, and perspectives across subject areas and grade levels (from kindergarten to grade 12). These changes are a direct response to the $94 \mathrm{rec}-$ ommendations in the TRC reports.

All of these efforts serve the purpose of indigenizing education. It is important to clarify a distinction here and provide some useful and concrete definitions, especially for those working in education. Indigenous education is decolonizing education: deconstructing colonial systems of education, creating new ones based on equity and Indigenous principles. Indigenizing education is the integration of Indigenous content, understandings, and processes into "formal" education systems. It is, perhaps, worth adding that the word "formal" most often refers to colonial education systems. This distinction between indigenous

59 First Peoples Principles of Learning: http://www.fnesc.ca/wp/wp-content/uploads/2015/09/ PUB-LFP-POSTER-Principles-of-Learning-First-Peoples-poster-11x17.pdf, accessed 30 April, 2016.

60 Chantelle Bellrichard, "10 books about residential schools to read with your kids: Stories open up 'space for conversation' with children, says educator," CBC News, 26 September, 2015, http://www.cbc.ca/news/indigenous/10-books-about-residential-schools-to-readwith-your-kids-1.3208021, accessed 30 April, 2016.

61 See: http://projectofheart.ca/what-is-project-of-heart/.

62 Ibid. 
education and indigenizing education is taken from Teaching Each Other: Nehinuw Concepts and Indigenous Pedagogies by Linda M. Goulet \& Keith N. Goulet. The authors draw on Cree concepts of education, which include magehin (teacher-directed instruction or learning from another), masowin (teaching oneself or self-directed learning), and matowin (teaching each other or learning in interaction with another). Goulet and Goulet argue that a balance between all three is ideal; in other words, learning to share decision-making power. ${ }^{63}$

These ideas can be applied more broadly through decolonization and the Indigenization of school systems and structures. For example, education systems can incorporate decolonization by identifying how their structures marginalize Indigenous people and how racism is embedded within classrooms and then work to address these issues by actually altering how they function. Indigenization of these institutions might include statements of land recognition being read before school functions and events, or hiring Indigenous teachers and professors, as well as reaching out to Indigenous communities and organizations in order to increase the intake of Indigenous students. However, it is important to keep in mind that the work of decolonization does not end with Indigenization efforts, an oversight continually made by settler educators and institutions at large, which are, after all, colonial in their very composition. Too often, listening to, accepting direction from, and acting upon the guidance of Indigenous teachers and students (even when solicited) fails to be implemented by those with power, demonstrating the degree to which Indigenous voices are undervalued.

\section{Land-based Education}

\section{Learning from the Land}

While colonialism has threatened Indigenous ways of life since first contact, colonizers initially relied on the knowledge of Indigenous peoples for years in order to colonize the land. Yet the IRS system attempted not only to assimilate Indigenous children to colonial values, but also intended to erase and eradicate Indigenous practices of learning. Once the colonial system was established, honoring treaties and cooperation with Indigenous people was regarded as an irrelevant artefact of colonizers of the past, a mindset which ultimately laid the foundations for the Canadian education system. For these reasons, listening to Indigenous scholars and leaders is critical if we are to really talk about recon-

63 Linda M. Goulet and Keith N. Goulet, Teaching Each Other: Nehinuw Concepts and Indigenous Pedagogies (Vancouver: UBC Press, 2014). 
ciliation through education. If education was used for genocide against Indigenous bodies, we must look towards educating non-Indigenous and Indigenous students through Indigenous leadership. If we are to listen, another message becomes quite clear. It is about land: protecting it, returning it, and also learning by and from the land. Leanne Betasamosake Simpson writes: "Like governance, leadership and every other aspect of reciprocated life, education comes from the roots up," adding that education "comes from being enveloped by land." ${ }^{\prime 64}$ Furthermore, multiple Indigenous scholars argue: "Land-based education, in resurging and sustaining Indigenous life and knowledge, acts in direct contestation to settler colonialism and its drive to eliminate Indigenous life and Indigenous claims to land." ${ }^{35}$ Across Canada, it has been written that land-based education provides "a space and a place for self-reflection." ${ }^{66} \mathrm{Gen}$ erally speaking, encouraging students to be self-reflexive and to think critically about their relationship to one another and to the land has been absent from Canada's education practices.

\section{Dechinta}

Dechinta is an Indigenous land-based center for research and learning in the north of Canada. The school offers students the opportunity to become part of a self-governing, sustainable community, and to learn about the environment, politics, and history of the Denendeh from Indigenous experts, leading professors, local leaders, and elders in a co-teaching environment. ${ }^{67}$ Student testimonials speak to the powerful experiences that take place in this unique setting. An Indigenous student writes: "I'm no longer afraid to express my opinions! ... I am a different person because of Dechinta University. I've turned into a hard worker, physically, mentally, emotionally, and spiritually!" ${ }^{68}$ On the other hand, a settler student notes: "my time here has been centered around the painful realizations of my implication in - and my internalization of colonialism - the

64 Leanne Betasamosake Simpson, "Land as Pedagogy: Nishnaabeg Intelligence and Rebellious Transformation," Decolonization: Indigeneity, Education, \& Society 3, no. 3 (2014), 9.

65 Matthew Wildcat, Mandee McDonald, Stephanie Irlbacher-Fox, Glen Coulthard, "Learning from the Land: Indigenous Land based Pedagogy and Decolonization," Decolonization: Indigeneity, Education \& Society 3, no. 3 (2014), III.

66 Ioana Radu, Lawrence M. House, Eddie Pashagumskum, "Land, Life and Knowledge in Chisasibi: Intergenerational Healing in the Bush," Decolonization: Indigeneity, Education \& Society 3, no. 3 (2014), 94.

67 "What Dechinta Offers," Dechinta, accessed 30 April, 2016, http://dechinta.ca/what-de chinta-offers/\#.

68 "Blog 2 - Rebecca," Dechinta, http://dechinta.tumblr.com/post/101004683930/blog-2-re becca, 26 October, 2014, accessed 30 April, 2016. 
horrors of my ancestry and my empty sacredless culture that continues to cause and be built on the oppression of Indigenous people ..."69 These testimonials powerfully demonstrate the program's ability to promote meaningful learning and self-reflexivity among its students. Erin Freeland Ballantyne, a member of staff at Dechinta University, writes:

Weaving and articulating a process where land based education, rooted in Indigenous values, teachings and teachers, and simultaneously accredited by the university, has been and continues to be a journey which simultaneously disrupts settlers and settler colonial enclosures of "education" while carving out space where practices which build self-determination strengthen. ${ }^{70}$

Dechinta offers its students learning opportunities that other educational institutions do not. In the words of Leanne Betasamosake Simpson: "We cannot bring about the kind of radical transformation we seek if we are solely reliant upon state-sanctioned and state-run education systems." ${ }^{\text {"1 }}$

\section{Arts-based Education}

\section{An Encounter with Marie Clements' The Unnatural and Accidental Women}

Arts-based education has been established as a meaningful way in which to enact social and political change. ${ }^{72}$ In Canada, arts-based social work and therapy are used to bring healing to Indigenous groups. ${ }^{73}$ Yet arts-based education that brings together Indigenous and non-Indigenous students is still relatively new. In 2015, the theatre program of Simon Fraser University put on the production An Encounter with Marie Clements' The Unnatural and Accidental Women.

69 “Blog Post 3 - Kira Anderson," Dechinta, 24 October, 2014, http://dechinta.tumblr.com/post/ 100829638185/blog-post-3-kira-anderson, accessed 30 April, 2016.

70 Erin Freeland Ballantyne, "Dechinta Bush University: Mobilizing a Knowledge Economy of Reciprocity, Resurgence and Decolonization," Decolonization: Indigeneity, Education, \& Society 3, no. 3 (2014): 68.

71 Simpson, "Land as Pedagogy: Nishnaabeg Intelligence and Rebellious Transformation," 13.

72 See Linda Archibald, "Dancing, Singing, Painting, and Speaking the Healing Story Healing through Creative Arts," Aboriginal Healing Foundation, 2012, http://deslibris.ca.ezproxy. library.ubc.ca/ID/234673, accessed 30 April, 2016.

73 See the "Holistic Arts-Based Group Methods with Aboriginal Women," (http://wwwl.uwind sor.ca/criticalsocialwork/holistic-arts-based-group-methods-with-aboriginal-women); C. Baskin, "Circles of Resistance: Spirituality in Social Work Practice, Education and Transformative Change," Currents: New Scholarship in the Human Services 1, no. 1 (2002); S. Hoffman, L. Kantner, C, Colbert, C., \& W, Sims, "Nurturing the Expressive Arts," Childhood Education, 68, no. 1 (1991): 23-26, and DW Newsome, D. A. Henderson \& L. J. Veach, "Using expressive arts in group supervision to enhance awareness and foster cohesion," Journal of Humanistic Counseling, Education \& Development 44, no. 2 (2005): 145-157. 
Exploring themes of gender-based violence, colonialism, and racism, the play takes inspiration from the lives of various Indigenous women murdered in Vancouver's Downtown Eastside (DTES) whose deaths were never adequately investigated or acknowledged. The production was directed by a white male settler (Steven Hill) in collaboration with an Indigenous dramaturge (Lindsay Lachance) and (rather controversially) performed by an all-settler student cast. Marie Clements is a well-known and critically acclaimed Métis playwright who gave her permission to the director and students for the production to take place in a classroom setting (the all-white cast would have otherwise been another example of discriminatory casting practices across the country). ${ }^{74}$

Each night, the stage directions were read by Cree actress Renae Morriseau alongside another Indigenous guest. The play finished with Renae Morriseau singing and was then followed by a talk-back between the director, students and audience. I remember that I came out of the theatre feeling a combination of feelings: unresolved, challenged, and awakened. I spoke with a settler student about her own experience as a performer and student in this class; she told me, "I experienced shame for my family's own participation in colonialism, and a deep shame for this province's complete failure to care about thousands of murdered women."75 This goes to show that educational experiences such as these are multi-faceted: that they deeply challenge the core of a student's beliefs and are (often) more giving to a student's learning than other common classroom experiences (i. e., attending a lecture, taking notes, or reading a textbook).

Lindsay Lachance's dramaturgy challenged students to look at the play through an Indigenous worldview that unsettled colonial notions of time, space and place, asking students to consider where they might be re-inscribing colonial relationships. ${ }^{76}$ Marie Clements' own ability to interlock and expand our understandings of time, space, and memory is demonstrated by this excerpt:

VIOLET:

She's sleeping. Dreaming parts of worlds, yours and mine and hers. Dreaming and pressing into things ... old memories and loves and waking in moments wondering where people ended and why even in sleep it hurts. Even in sleep, it occurs, and reoccurs and you wake half here, half there, everything separated.

\section{REBECCA:}

Everything not quite there, because you can't quite touch your own loss. Because it is so hollow. $^{77}$

74 Steven Hill, conversation with author, 11 June, 2015.

75 Valerie Christiansen, email correspondence with author, 21 June, 2015.

76 Lindsay Lachance, conversation with author, 22 May, 2015.

77 Marie Clements, The Unnatural and Accidental Women (Vancouver: Talonbooks, 2005), 79. 
The play explores questions between the living and the dead. Lachance's dramaturgy brought forth the notion that the women have agency after their deaths. After the production, she asked the students, "So now what?", reminding them that violence upon Indigeneity and Indigenous bodies continues even after the school term is over. ${ }^{78}$

Steven Hill, too, remarked that the piece was an "incomplete" and "unsatisfying" gesture and that everyone involved was very aware of this "non-redemption"; yet he also pointed out that the production was ultimately directing some responsibility back to the audience to "bear witness to the student's learning.",79 Deneh Thompson, an Indigenous playwright and actor, participated as a student in the course during the first part of the year. The first term focused on the research process and play-making aspects. He provided the following remarks as a form of conclusion:

I want to say that the most important part of this show, and the intention of Steven Hill and the entire team, was the community discussions that happened at the show and in the community. Doing this play in this context is inherently problematic, but we all need to find ways to address issues like MMIW. ${ }^{80}$ We all: Aboriginal people, settlers, artists, men, women, allies, government, activists, academics, community members, I mean ALL of us. Creating spaces for constructive discussion is at the heart of this work, and we need more like it. ${ }^{81}$

\section{Conclusion}

There is no doubt that "reconciliation" looks different depending on where one stands: what one stands to gain and what one stands to lose. The significance and meaning of "reconciliation" is contingent upon the lived experiences one carries, as well as whether one is Indigenous or not. In 2015, the hashtag "\#My ReconciliationIncludes" gained popularity with social media users. The idea behind the hashtag is that reconciliation goes beyond the vocabulary of the TRC mandate. The hashtag is still regularly used as a form of contesting dominant narratives around the TRC and reminding Canadians that the work of reconciliation is far from finished.

Canadian youth must be included in and incorporated into the ongoing work of reconciliation. Sarah Hunt, a Kwagiulth (Kwakwaka'wakw) writer and scholar, offered the following insight in a recent talk: "I was surprised to find that the TRC calls to action only include one directive aimed at youth - just one - there are five

78 Lindsay Lachance, conversation with author, 22 May, 2015.

79 Steven Hill, conversation with author, 11 June, 2015.

80 MMIW: missing and murdered Indigenous women.

81 Deneh Thompson, email correspondence with author, 22 June, 2015. 
for sports and one for youth. I'm not being critical of the Commissioners here alone, but fear that this reflects a continuing de-valuation within our own communities of young people." ${ }^{\prime 2}$ Newer organizations such as the 4Rs Youth Movement (respect, reciprocity, reconciliation, and relevance) seek to change the relationship between Indigenous and non-Indigenous youth through collaboration and conversation.

Beyond dialogue, it is evident that education systems must be Indigenized and education itself must be decolonized in Canada. Ultimately, Indigenous and nonIndigenous students and teachers alike must be brought together both inside and outside of institutional classroom settings in order to tackle the injustices that have existed in Canada for hundreds of years. In the aftermath of the TRC, the decolonization of education practices is a necessary step towards dismantling colonialism at large; a difficult assignment and one that remains the responsibility of all individuals living on Indigenous land. And ultimately, perhaps one of the larger lessons and the ultimate responsibility facing the field of transitional justice and its practitioners, is the inclusion and involvement of youth, educators, and Indigenous leadership in all discourse and application of transitional justice mechanisms.

\section{Bibliography}

APTN. "Number of Indian residential school student deaths may never be known: TRC." APTN National News. 2 June, 2015. http://aptn.ca/news/2015/06/02/number-indianresidential-school-student-deaths-may-never-known-trc/. Accessed 30 April, 2016.

Archibald, Linda. "Dancing, Singing, Painting, and Speaking the Healing Story Healing through Creative Arts.” Aboriginal Healing Foundation, 2012. http://deslibris.ca.ez proxy.library.ubc.ca/ID/234673. Accessed 30 April, 2016.

Baskin, C. "Circles of Resistance: Spirituality in Social Work Practice, Education and Transformative Change." Currents: New Scholarship in the Human Services 1, no. 1 (2002).

BC Teachers' Federation. "Education for reconciliation: BCTF launches new resource on residential school history in BC.” BC Teachers' Federation. https://bctf.ca/pub lications/TeacherArticle.aspx?id=38000. Accessed 30 April, 2016.

Belcourt, Billy-Ray. "The day of the TRC Final Report: On being in this world without wanting it." The Rabble, 15 December, 2015, http://rabble.ca/news/2015/12/day-trcfinal-report-on-being-this-world-without-wanting-it. Accessed 30 April, 2016.

Bellrichard, Chantelle. "10 books about residential schools to read with your kids: Stories open up 'space for conversation' with children, says educator.” CBC News, 26 September,

82 Sarah Hunt, "Emma Talks Lecture," unpublished paper presented at Simon Fraser University, 27 April, 2016. 
2015, http://www.cbc.ca/news/indigenous/10-books-about-residential-schools-to-readwith-your-kids-1.3208021 Accessed 30 April, 2016.

Betasamosake Simpson, Leanne. Dancing On Our Turtle's Backs: Stories of Nishnaabeg Recreation, Resurgence, and A New Emergence. Winnipeg: ARP Books, 2011.

Betasamosake Simpson, Leanne. "Land as Pedagogy: Nishnaabeg Intelligence and Rebellious Transformation.” Decolonization: Indigeneity, Education, \& Society 3, no. 3 (2014).

Betasamosake Simpson, Leanne. "Queering Resurgence: Taking on Heteropatriarchy in Indigenous Nation Building.” 1 June, 2012. http://leannesimpson.ca/queering-re surgence-taking-on-heteropatriarchy-in-indigenous-nation-building/. Accessed 30 April, 2016.

CBC News. "Aboriginal languages in Canada can and should be made official, expert says." 11 July, 2015. http://www.cbc.ca/news/canada/british-columbia/aboriginal-languagesin-canada-can-and-should-be-made-official-expert-says-1.3147759. Accessed 30 April, 2016.

CBC News, "A Timeline of Residential Schools, the Truth and Reconciliation Commission." CBC News, 25 March, 2014. http://www.cbc.ca/news/canada/a-timeline-of-residentialschools-the-truth-and-reconciliation-commission-1.724434. Accessed 30 April, 2016.

CBC News. "New Heritage Minute explores dark history of Indian residential schools." 21 June, 2016. http://www.cbc.ca/news/aboriginal/new-heritage-minute-explores-darkhistory-of-indian-residential-schools-1.3643363. Accessed 21 June, 2016.

Cherrington, Mark. “Oh, Canada!” Cultural Survival, Fall 2007. https://www.cultur alsurvival.org/publications/cultural-survival-quarterly/canada/oh-canada. Accessed 30 April, 2016.

Clements, Marie. The Unnatural and Accidental Women. Vancouver: Talonbooks, 2005.

Coulthard, Glen. Red Skin, White Masks: Rejecting the Colonial Politics of Recognition. Minneapolis: University of Minnesota Press, 2014.

Dechinta Centre for Research and Learning. "What Dechinta Offers.” http://dechinta.ca/ what-dechinta-offers/\#. Accessed November 2017.

Dechinta Bush University. "Blog 2 - Rebecca." http://dechinta.tumblr.com/post/10100468 3930/blog-2-rebecca. 26 October, 2014. Accessed November 2017.

Dechinta Bush University. "Blog Post 3 - Kira Anderson.” 24 October, 2014. http://de chinta.tumblr.com/post/100829638185/blog-post-3-kira-anderson. Accessed 30 April, 2016.

Durocher, Elaine. Statement to the Truth and Reconciliation Commission of Canada. Winnipeg, Manitoba. 16 June, 2010. Statement Number: 02-MB-16JU10-059.

First Nations Education Steering Committee. “About FNESC.” FNESC. http://www.fnesc. ca/about-fnesc. Accessed 30 April, 2016.

First Peoples Principles of Learning. http://www.fnesc.ca/wp/wp-content/uploads/2015/ 09/PUB-LFP-POSTER-Principles-of-Learning-First-Peoples-poster-11x17.pdf.

FNESC and FNSA. "The British Columbia First Nations Education System.” Vimeo. https:// vimeo.com/44493997. Accessed 30 April, 2016.

Fratila, Stefana. "Decolonizing Reconciliation: Refusing Settler Innocence Through Sound.” University of British Columbia. https://open.library.ubc.ca/cIRcle/collections/ ubctheses/24/items/1.0228649. Accessed 30 April, 2016. 
Freeland Ballantyne, Erin. "Dechinta Bush University: Mobilizing a Knowledge Economy of Reciprocity, Resurgence and Decolonization." Decolonization: Indigeneity, Education, \& Society 3, no. 3 (2014), 68.

Goulet Linda M. and Keith N. Goulet. Teaching Each Other: Nehinuw Concepts and Indigenous Pedagogies. Vancouver: UBC Press, 2014.

Daniel Heath Justice. 21 November 2015. https://www.facebook.com/daniel.justice.7393/ posts/535094576666580. Accessed 30 June, 2016.

Hoffman, S., L. Kantner, C, Colbert, C., and W, Sims. "Nurturing the Expressive Arts." Childhood Education 68, no. 1 (1991): 23-26.

LaRocque, Emma. When the Other is Me. Native Resistance Discourse, 1850-1990. Manitoba: University of Manitoba Press, 2010.

Newsome, D.W., D. A. Henderson and L. J. Veach. "Using Expressive Arts in Group Supervision to Enhance Awareness and Foster Cohesion." Journal of Humanistic Counseling, Education \& Development 44, no. 2 (2005): 145-157.

Niezen, Ronald. Truth \& Indignation: Canada's Truth and Reconciliation Commission on Indian Residential Schools. Toronto: University of Toronto Press, 2014.

O'Keefe, Derrick. "Harper in denial at G20: Canada has 'no history of colonialism'," Rabble, 28 September, 2009. http://rabble.ca/blogs/bloggers/derrick/2009/09/harperdenial-g20-canada-has-no-history-colonialism. Accessed 30 April, 2016.

Palmater, Pamela D. “Canada's residential schools weren't killing culture, they were killing Indians." The Rabble. 9 June, 2015, http://rabble.ca/blogs/bloggers/pamela-palmater/ 2015/06/canadas-residential-schools-werent-killing-culture-they-were. Accessed 30 April, 2016.

Project of Heart. http://projectofheart.ca/what-is-project-of-heart/. Accessed 15 November, 2017.

Puxley, Chinta. "Feds stopped keeping track of children who died in residential schools 'probably because rates were so high'.” National Post. 31 May, 2015, http://news.na tionalpost.com/news/canada/feds-stopped-keeping-track-of-children-who-died-inresidential-schools-probably-because-rates-were-so-high. Accessed 30 April, 2016.

Puxley, Chinta. "Restoring indigenous languages, key to preventing youth suicides, Trudeau says.” Toronto Star. 3 June, 2016, https://www.thestar.com/news/canada/2016/06/ 03/restoring-indigenous-languages-key-to-preventing-youth-suicides-trudeau-says. html. Accessed 30 June, 2016.

Radu, Ioana, Lawrence M. House, and Eddie Pashagumskum. "Land, Life and Knowledge in Chisasibi: Intergenerational Healing in the Bush.” Decolonization: Indigeneity, Education \& Society 3, no. 3 (2014).

Sasagawa, Emi. "Workshop explores ways of supporting Indigenous students at UBC." UBC. 16 May, 2016. Accessed 30 May, 2016: http://aboriginal.ubc.ca/2016/05/16/work shop-explores-ways-of-supporting-indigenous-students-at-ubc/.

Schwartz, Daniel. "Truth and Reconciliation Commission: By the Numbers." CBC News. 2 June, 2015, http://www.cbc.ca/news/aboriginal/truth-and-reconciliation-commissionby-the-numbers-1.3096185. Accessed 30 April, 2016.

Smith, Linda Tuhiwai. Decolonizing Methodologies. Research and Indigenous People. New York: Zed Books, 2012. 
Staniforth, Jesse. “'Cultural genocide'? No, Canada committed regular genocide.” Toronto Star. 10 June, 2015. https://www.thestar.com/opinion/commentary/2015/06/10/culturalgenocide-no-canada-committed-regular-genocide.html. Accessed 30 April, 2016.

Truth and Reconciliation Commission of Canada. Honouring the Truth, Reconciling for the Future. Summary of The Final Report of the Truth and Reconciliation Commission of Canada. Montreal and Kingston: Truth and Reconciliation Commission of Canada, 2015.

Truth and Reconciliation Commission. "Canada's Residential Schools: The History, Part 1 Origins to 1939", The Final Report of the Truth and Reconciliation Commission of Canada, 6 volumes. Winnipeg: Truth and Reconciliation Commission of Canada, 2015.

Truth and Reconciliation Commission. "Canada's Residential Schools: The History, Part 2 1939 to 2000", The Final Report of the Truth and Reconciliation Commission of Canada, 6 volumes. Winnipeg: Truth and Reconciliation Commission of Canada, 2015.

Truth and Reconciliation Commission. "Truth and Reconciliation Commission: Calls to Action.” Winnipeg: Truth and Reconciliation Commission, 2015.

Truth and Reconciliation Commission of Canada. Survivors Speak. Winnipeg: Truth and Reconciliation Commission of Canada, 2015.

Truth and Reconciliation Commission. "Canada's Residential Schools: The Legacy." The Final Report of the Truth and Reconciliation Commission of Canada, 6 volumes. Winnipeg: Truth and Reconciliation Commission of Canada, 2015.

University of British Columbia. “The Indian Act.” Indigenous Foundations. University of British Columbia. http://indigenousfoundations.arts.ubc.ca/home/government-poli cy/the-indian-act.html. Accessed 30 April, 2016.

University of Windsor. "Holistic Arts-Based Group Methods with Aboriginal Women." http://wwwl.uwindsor.ca/criticalsocialwork/holistic-arts-based-group-methods-withaboriginal-women.

Wildcat, Matthew, Mandee McDonald, Stephanie Irlbacher-Fox, and Glen Coulthard. "Learning from the Land: Indigenous Land based Pedagogy and Decolonization." Decolonization: Indigeneity, Education \& Society 3, no. 3 (2014).

Wolfe, Patrick. "Settler colonialism and the elimination of the native." Journal of Genocide Research 8, no. 4 (2006). 
Part II:

Education in Transitional Justice Contexts: Actors and Practices 
Open-Access-Publikation im Sinne der CC-Lizenz BY 4.0

(c) 2018, V\&R unipress $\mathrm{GmbH}$, Göttingen 


\section{Inappropriate Transgressions: Reanimating Necropolitics via Memorialization in Rwanda}

The Murambi Genocide Memorial Center in Gikongoro, Rwanda, constitutes an attempt to commemorate the massacre that occurred there in April of 1994 by preserving its remnants. In 1993, Murambi had opened as a polytechnic teaching college, the Ecole Technique Officielle for the southern region. One year later, during the genocide against the minority Tutsi and moderate Hutu that shattered the country, it hosted the massacre of 45,000 individuals who had been corralled there under the auspices of safety, guaranteed by members of the military that ultimately slaughtered them.

Today, the main building of the college has been transformed into a genocide education center that houses a walking exhibition and classrooms that are commonly used to host visiting school groups, dignitaries, or commemorative events. The walking exhibition provides the viewer with a rendition of history that is closely policed by the Rwandan government with special attention paid to the history of violence in and around Gikongoro between 1959 and 1994. This span of time is denoted as a "generation of genocide" that culminates in the bombardment of Murambi by the interahamwe between April 19 and 22, 1994. The exhibit is similar to those that can be found at other national memorial sites, such as the well-known Gisozi Memorial Center in Kigali. Also similar is the preservation of the grounds where the massacre took place. Demarcations of mass graves dot the landscape; piles of clothes, shoes, and other personal items can be found in outbuildings. And, like other sites of memory in Rwanda, the silence and beauty of the hilltop setting eerily contrasts with the realities of the horror that once visited the place.

What differentiates Murambi from other memorial spaces in the country and raises the questions highlighted below is the use of victims' corpses within the

1 The interahamwe, a word that literally means "those who work together," are a paramilitary group organized and trained by officials within the government of Juvenal Habyarimana. Localized cells were trained, initially, as a response to the emerging civil war that broke out in the north of the country when the Rwandan Patriotic Front attempted to re-nationalize from Uganda. 
memorial. Inside the school classrooms, the very spaces where genocide victims were slaughtered, visitors can come into direct contact with their mummified corpses. Three dozen rooms are filled with bleach-white bodies, laid out on makeshift slat tables that ensure they remain dry. The preservation has been quite astounding. Skin remains intact, some bodies have been dressed by friends and relatives, some clutch rosaries, and many maintain the facial expressions or contortions of the fading moments of their lives. The visitor can approach these bodies at whatever distance they like, for no barriers protect the bodies from the spectator's touch.

The following chapter questions the utilization of corpses at the Murambi Genocide Memorial Center. While it attests to social issues that are prevalent in present-day Rwanda, its argumentative focus is oriented toward theoretical questions regarding commemoration and public history. In particular, the memorial in question is employed within a broader educational mission focused on generating peace and stability within the country. Accordingly, this chapter questions whether the exhibition of corpses is beneficial to this broader curriculum in civic training. This angle of inquiry is useful for two reasons. First, it opens the discussion beyond the boundaries of Rwanda by calling into question the legitimacy of certain methodological approaches to commemoration and its educative potential. Second, it serves as a genuine reflection on the common belief that knowledge is crucial for social advancement.

The Rwandan government, in alignment with most nations that have suffered atrocities, believes that memorials are "crucial to bearing witness, countering genocide denial and solidifying the enduring exceptional status of survivors in perpetuity." 2 This belief also explicitly links commemoration to history education and, in turn, to the process of peacebuilding throughout the post-genocide state. In 2012, for example, a week of commemorative services were organized around the theme "learning from our history to build a brighter future." At the opening ceremonies on April 7, President Paul Kagame spoke to a large crowd in Kigali's Amahoro Stadium. In his speech he declared that "we will always remember ... So that even those who did not experience [the 1994 genocide] may learn the history of the genocide and its causes, and draw lessons that will make it impossible to repeat it. That's the value of history." ${ }^{3}$ During the same week, the

2 Kristin Doughty, "Memorials, Human Remains and Controversy in Post-Genocide Rwanda," Anthropology News: In Focus (September 2011), http://www.anthropology-news.org, accessed 11 November 2015.

3 Paul Kagame, "Speech by H.E. Paul Kagame at the 18th Commemoration of the Genocide Against the Tutsi," 7 April, 2012, http://www.paulkagame.com/2010/index.php?option=com_content\& view $=$ article $\& \mathrm{id}=630 \% 3 \mathrm{Aspeech}$-by-he-paul-kagame-president-of-the-republic-of-rwandaat-the-18th-commemoration-of-the-genocide-against-the-tutsi-amahoro-stadium-7-april-2012 $\&$ catid $=34 \% 3$ Aspeeches $\&$ Itemid $=56 \&$ lang $=$ en, accessed 15 November, 2012. 
director of the National Commission for the Fight Against Genocide (CNLG), Jean de Dieu Mucyo, suggested that "the youth of Rwanda have the great responsibility of - and opportunity to - learn from the past and work together to build a united country, free of genocide ideology."4 This sentiment is a reiteration of his own words now emblazoned along the exhibition wall at Murambi: "education and memory are the foundations of a peaceful future." 5

Given the impetus of memorialization to provide a guiding light from the past toward the future, it is imperative that we analyze the methods employed by memorials as educational spaces. As mentioned previously, this conversation moves well beyond the context of Rwanda, for neither Mucyo nor Kagame are suggesting something radical or even novel. Indeed, there are a number of platitudes that invoke the commonplace logic of avoiding the repetition of history by way of learning about the past and the Rwandan president's assessment that the "value of history" is precisely its capacity to influence the future is widespread. However, the manner in which history is deployed matters to an equal extent. A valuable lesson can be undermined by a problematic methodology; and the chosen methodology provides a lesson in itself about how to engage with a subject. In short, these platitudes must be seriously critiqued and challenged, especially when the stakes of history education are compounded by tragedy.

In the context of Rwanda the problem of sifting through public history is complicated by the fact that the government is highly sensitive in regard to the narratives that are allowed to circulate. At times, they appear to lean on the history of places like Murambi as justification for sociopolitical practices that are largely repressive. This chapter responds to the memorial and, in so doing, points to the underlying problems inherent in this educational strategy in a postdisaster society. If we take the Kagame government at their word, this chapter still effectively critiques the practices of public history they employ as antagonistic to their proclaimed goals of sustainable peace and democracy. If we remain cynical of the so-called Government of National Unity (henceforward referred to as GNU), this chapter lends credence to our suspicions of their underlying intention to silence opposition. Either way, it also serves as an opportunity to reflect on practices of public history in places that we may label as "open societies." Foundational to this examination is the belief that we must elevate our critical awareness of public pedagogies if we are going to resist the closure of social and political space.

4 Hope Magazine, "18th Genocide Commemoration: 'Learning from our history to build a bright future," http://www.hope-mag.com/news.php?option $=$ lnews \& $c a=1 \& a=90$, accessed 18 November, 2012.

5 Murambi Exhibition Walls, personal observation, Gikongoro, 11 January, 2012. 
The following examination will expose one specific pitfall of peacebuilding educational projects that lean heavily on the aforementioned correlation between learning and progress. Murambi constitutes an exemplary model of memorialization that relies on commemorating history while generating or accentuating a sense of prohibition. The essay contends implicitly that relying on a negative response (i.e. "don't do this") is an ineffective way to build a sustainably peaceful society. Although space will limit the ability to render this argument fully here, it should be noted that prohibition-focused educational models guide learners toward allegiance and dogmatism. Creating binary oppositions between what is acceptable and unacceptable within history further limits the learner's capacity and willingness to engage with disparate discourses of knowledge and, in turn, makes the rejection of out-group models more dramatic. Furthermore, it follows that widespread willingness to defer to authority on matters pertaining to history, identity, and social normativity are antagonistic to the goals of generating a self-sufficient citizenry, which is a fundamental requirement for a stable community.

\section{The Appropriate and Appropriable}

In order to be effective historical devices, memorial representations of atrocities must find a space that is neither too sterilized nor too visceral. In both realms of excess, problems regarding the social and political efficacy of such programs for history education become immediately discernable. If depictions of violence are overly censored, the realities of trauma may not be impactful enough to challenge the viewer, generate questions, or compel calls for justice. Sterilized history can easily be swept under the rug, easily forgotten, and paved over by flashier events within the past. Victors often drift toward this extreme in hopes that any historical violence they perpetrated will be glossed over by a story that avoids ruffling feathers, exposing their cruelty, or implicating them in anything that is an obvious crime. Such errors in representation are widely considered inappropriate insofar as they generate space for revision or wholesale denial.

At the other end of the spectrum is what Susan Sontag has described as "intolerable realism." In these cases, representations of violence are too raw or morbid to be appropriate, which can render the viewer educationally inert or even antagonistic to the goals of healing, reconciliation, or peacebuilding. When the viewer is confronted with an overabundance of images of suffering, the response will often be to look away in disgust out of a sense of what is proper. They may also feel overwhelmed afterwards, incapable of responding to the

6 Susan Sontag, Regarding the Pain of Others (New York: Picador, 2003), 63. 
onslaught on their senses. Alternatively, the viewer may be traumatized by the representations of violence that conjure feelings akin to the historical realities of conflict. In short, generating, reproducing, or preserving images - much less entire scenes - of suffering must capture the viewer's attention while not transgressing their sensibilities inappropriately.

The use of corpses at Murambi errs on the side of the intolerably real. In an effort to convince the onlooker of the weight of the tragedy, numerous memorials worldwide choose to render an historical event through stark representations of its most morbid details. At the Topography of Terror museum in Berlin, for example, visitors can watch the only known video of a mass execution by Nazi shooters. The main building at the center of the Killing Fields in Cambodia is filled with human bones. Murambi's exceptionality is thus not its methodology, but its ability to push this methodology to its most dramatic horizon. Murambi is the example, par excellence, within a broader problem that confronts all communities attempting to wrest lessons from the tragic past.

\section{Images of the Murambi Genocide Memorial Center, Gikongoro, Rwanda (Photographs taken by the author)}

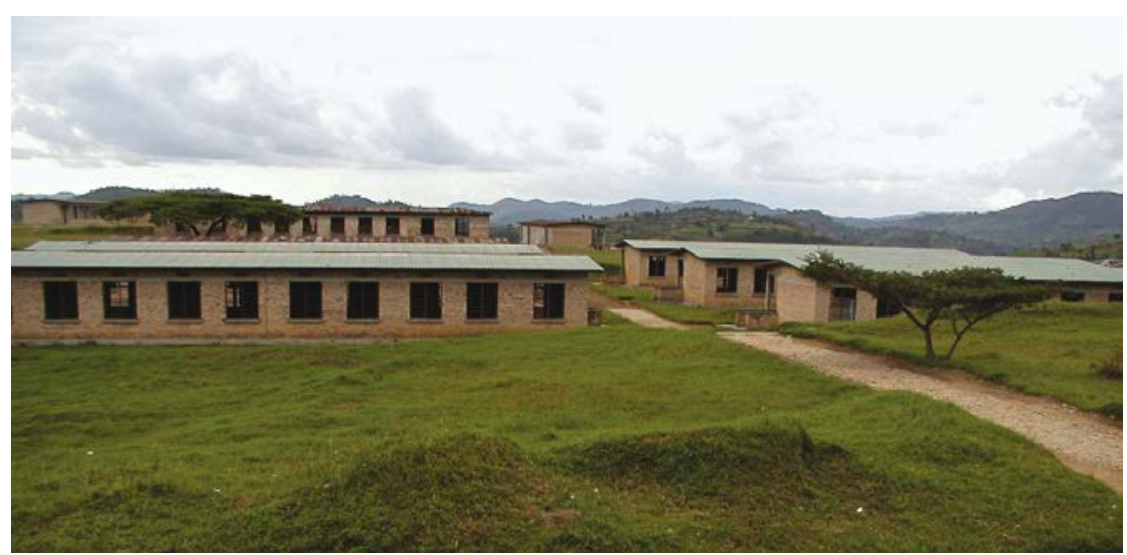



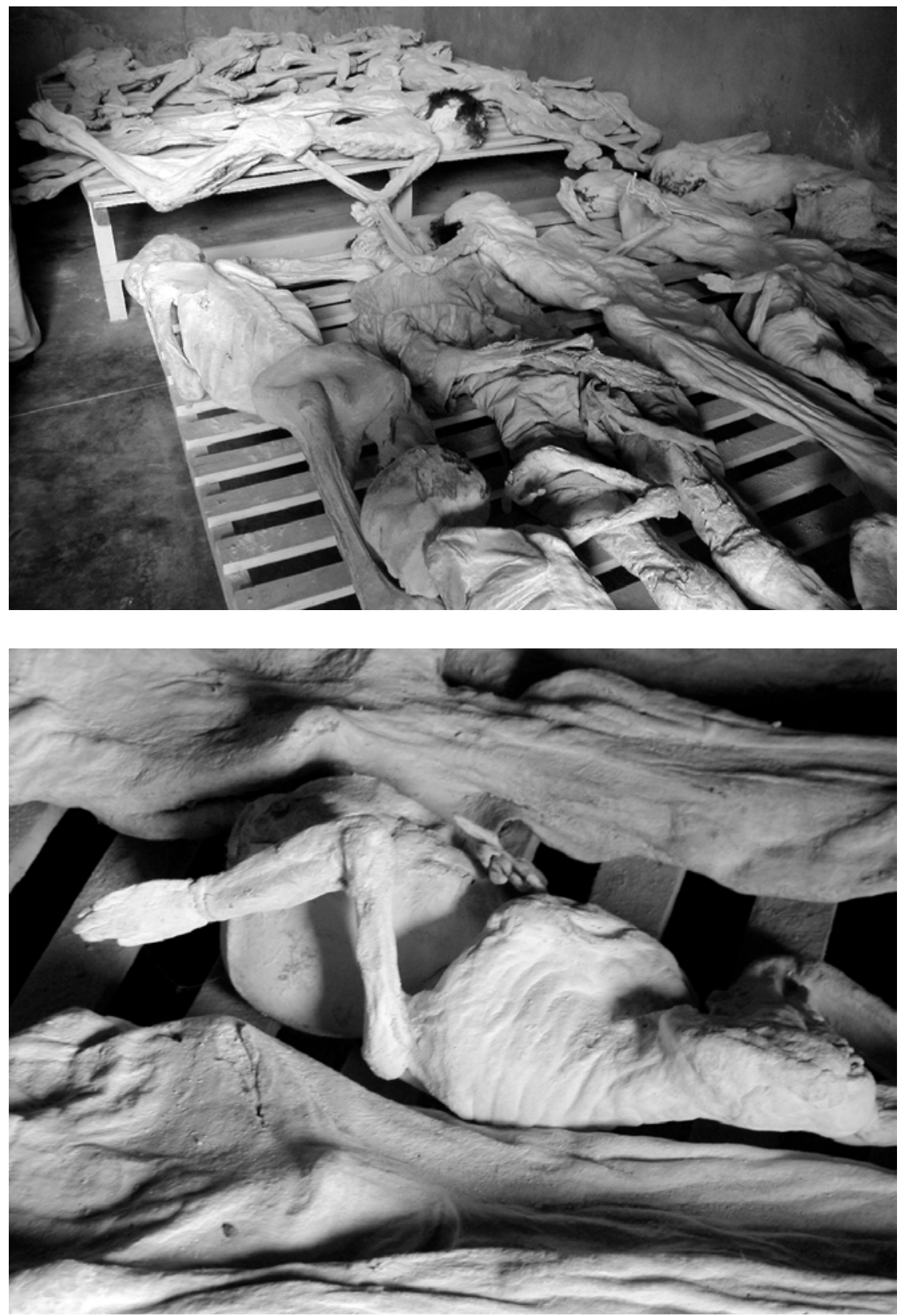

Open-Access-Publikation im Sinne der CC-Lizenz BY 4.0

(c) 2018, V\&R unipress $\mathrm{GmbH}$, Göttingen

ISBN Print: 9783847108375 - ISBN E-Lib: 9783737008372 

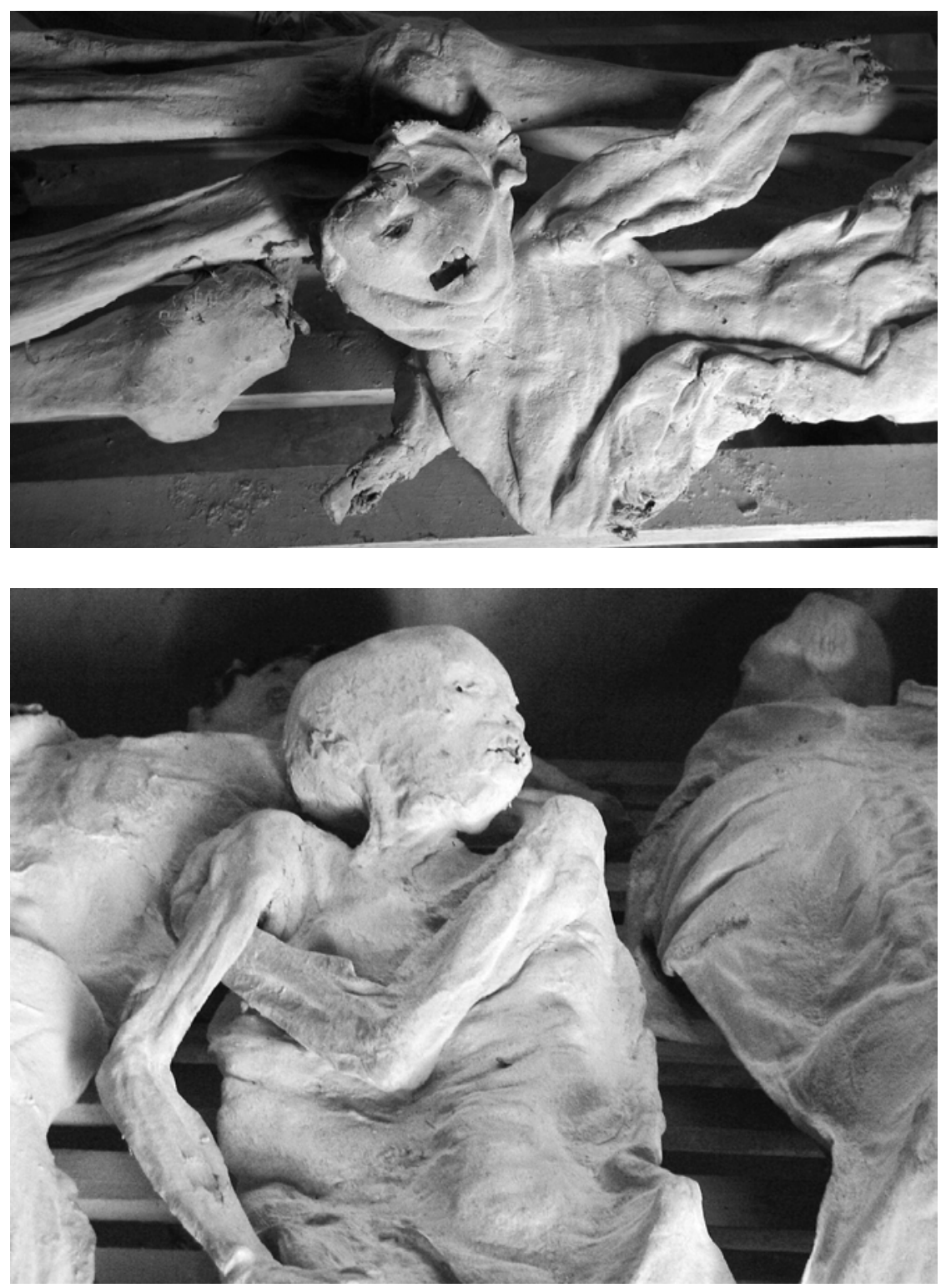

Open-Access-Publikation im Sinne der CC-Lizenz BY 4.0 
We can begin to problematize this strategy, then, by noting an initial fallacy in the logic that founds this compulsion to produce negative responses to violence through an exposition of its cruelty. Simply put, the heinous results of violence do not constitute an argument against bloodshed, war, or crimes against humanity. There are no lessons inherently embedded within carnage that lead the witness, bystander, or viewer to reject violent actions. On the contrary, as Susan Sontag suggests, scenes of death are pornographic; they inspire a morbid curiosity and a voyeuristic intrigue that compels us to stare. Like all forms of pornography, they compose a scene that is intended to excite the carnal or emotional - but not the rational. They inscribe the viewer into a scene that conjures innate responses rather than rational or critical ones. What is learned through this inscription emerges from one's own prohibitive rejection of death, which is concomitant with the will to survive by any means necessary, including violence. Thus, depictions of violence that are too real can induce in the viewer a state of violent reaction rather than non-violent critique, contemplation, or peaceful stoicism.

These fundamental reflections echo the sentiments of French philosopher Georges Bataille, who accounted for the human confrontation with death in his essays on Death and Sensuality (1957). Highlighting this same aspect of too much or too little exposure, Bataille writes "violence, and death signifying violence, have a double meaning. On the one hand the horror of death drives us off, for we prefer life; on the other an element at once solemn and terrifying fascinates us and disturbs us profoundly." 7 The profundity of the corpse is derived from the fact that it "is the image of [man's] own destiny. It bears witness to a violence which destroys not one man alone but all men in the end." 8 Thus, what causes us to recoil from the dead is the recognition of oneself within the figure of death. As mortal beings, we all share the same fate, which simultaneously compels and repulses us through the promise of continuity inherent in death.

As he navigates through an understanding of our relationship to death, Bataille is outlining the structure of taboo or prohibition. Within his philosophical constellation, prohibitions - such as burying the dead to avoid continued interaction with it - are what form the determining structures of social and political life. Humans order their existence through two primary mechanisms that work in tandem. First, we generate rules that prohibit us from certain behaviors that threaten our biological or psychological continuity. Second, we engage in rituals that transgress these rules, subtly expose us to the taboos we have established, and, in turn, reinforce these very maxims. In other words, society is

7 Georges Bataille, Erotism: Death and Sensuality, translated by Mary Dalwood (San Francisco: City Lights, 1986), 45.

8 Ibid., 44. 
founded on our exposure to transgression. As Bataille declares, "organized transgression together with the taboo make social life what it is." therefore, than fully prohibiting our exposure to the other - even the other is death itself - one must allow for a certain level of vulnerability. This means risking some form of injury to one's sense of self in order to engage in society, including and especially in the political realm. This alludes to the concept of the political established in Antiquity, where logos, which is more of a discursive sharing than merely a form of logic or speech, was a prerequisite for politics. By Bataille's calculations too, we must be willing to confront our taboos, transgress our prohibitions, and expose ourselves to an Other in order to engage actively in the world.

Bataille's work highlights the reasons behind our social rituals concerning the dead. Following his conceptualization, it is not surprising that we maintain sites that provide opportunities to expose ourselves to those who have passed away. Rituals associated with death help realign or strengthen our own sociopolitical structures since death is the taboo to which all others allude. Indeed, of all possible transgressions, Bataille suggests that the profound feeling of "anguish is greatest in the face of death" but that it is "what men desire in order to transcend it beyond death and ruination." 10 The torment that accompanies the vision of the dead is useful for re-establishing our ordered existence and reflections about death allow us to confront our own mortality in potentially constructive ways. It seems that Bataille is outlining the basic rationale behind memorializing atrocity insofar as it relies on the profundity of an interaction with death that challenges us to evaluate and improve the way in which we live. It would appear that reflections from this "transcendent" movement can be educational (which is to say appropriable and influential) on an ethical, metaphysical, social, or political plane and can energize the community's investment in building new structures, institutions, or traditions.

However, Bataille is careful to insert a caveat into the discussion by noting that not all encounters with death are useful. He stops short of wholly advocating the induction of anguish with the purpose of transcending it by pointing out that mortal despair "can be overcome ... on one condition only, namely, that the anguish shall be appropriate to the spirit of the man who desires it."11 We thus return to the question of appropriateness as it pertains to levels of exposure or transgression. Failing to confront the continuity of death - or of any other taboo for that matter - means living in an unexamined world in which one's movements will be dictated entirely by normative structures. On the other hand,

9 Ibid., 65.

10 Ibid., 87.

11 Ibid., emphasis added. 
"when the bounds of the possible are over-reached, a recoil is inevitable." ${ }^{12}$ Overexposure causes us to cling steadfastly to the established order, which will ensure that we avoid continued vulnerability. What this reveals is that the same structures sustained by the unexamined life are vigorously defended and accentuated by the life that is over-exposed: "a feeling of nausea would gain the upper hand and reinforce the taboos." ${ }^{\prime 3}$ In these moments, the onlooker clings to his or her sense of prohibition, to the rejection of death at a fundamental level. This disables the possibility of engaging with subjects of mortality on a conceptual level and, in turn, garnering any appropriable lesson from the encounter with death. And if the true goal of a memorial is to transform a community that has recently been gripped by a fear of death, the practice of reinforcing prior conceptions and taboos of death appears to negate these goals.

\section{Necropolitical Lessons}

Rather than simply negating the goals of social transformation and peacebuilding, I will argue that Murambi's lessons work in opposition to these aims. What I see reanimated at Murambi resembles that which Cameroonian political philosopher, Achille Mbembe, has defined with the term "necropolitics." In an article by the same name, Mbembe resumes the argument where Bataille left it. He summarizes the latter's reflections with a concise definition of politics as "the difference put into play by the violation of a taboo." 14 This corroborates the aforementioned suggestion that all discursive interaction in the public realm is initiated at the moment when we allow for a transgression of our normal prohibitions via the influence of an other. Mbembe is also keen to hone in on death as an important factor in political and social structures. In fact, necropolitics refers directly to the idea of "politics as a work of death" wherein sovereignty - which is cooperative with, though not limited to, power - is "expressed predominantly as the right to kill." ${ }^{15}$ As he highlights through an historical overview, this conception of sovereignty constitutes the dominant paradigm of the modern nation state, or "the nomos of the political space in which we still live." ${ }^{16}$ Like Bataille, Mbembe's analysis is highly critical of this conceptual framework and the resultant policies that are initiated on its behalf.

The morbid expression of sovereignty is most highly visible in contested

12 Ibid.

13 Ibid., 88, emphasis added.

14 Achille Mbembe, "Necropolitics," translated by Libby Meintjes, Public Culture 15, no. 1 (2003): 11-40, 16.

15 Ibid., 16.

16 Ibid., 14. 
spaces, and it is from within such localities that Mbembe initiates his critique. In the state of exception or emergency, the paradigm of "power still depends on a tight control over bodies." ${ }^{17}$ When power is contested, however, technologies of control "are less concerned with inscribing bodies within disciplinary apparatuses as inscribing them, when the time comes, within the order of the maximal economy represented by the "massacre."'18 The act of killing delineates the enemy from the friend in a binary rendition of politics as has been described by the likes of Carl von Clausewitz and Carl Schmitt. In such instances where power is up for grabs, the slain becomes the enemy and the survivor the friend. Moreover, the friend is guaranteed this status, concomitant with life, by the force that killed.

In contested territories the task for the aspiring power (the rebel offensive, the terrorist group, the newly-crowned State) is "to keep before the eyes of the victim - and of the people around him or her - the morbid spectacle of severing" ${ }^{\text {"19 }}$ or of death. We see this repeatedly in reports about the Kivu region in the Democratic Republic of Congo, northern Pakistan, or territories contested by the Islamic State: civilians massacred, villages razed, and bodies mutilated and strewn over the area. The point of leaving a trail of corpses is to align consent. To maintain sovereign rule means asserting oneself as the primary authority over death and, therefore, life in a given space. A massacre provides an immediate lesson for those who endure it or discover its remnants: align yourself with this force that can kill or risk your own death. Mbembe equates this lesson to the logic of the survivor "who, having stood in the path of death, knowing of many deaths and standing in the midst of the fallen, is still alive." ${ }^{20}$ What he underscores is the fact that within this framework,

"Each man is the enemy of every other." Even more radically, in the logic of survival one's horror at the sight of death turns into satisfaction that it is someone else who is dead. It is the death of the other, his or her physical presence as a corpse that makes the survivor feel unique. ${ }^{21}$

In this maximal economy where political status and biological survival are directly intertwined, the survivor's uniqueness is attached to the fact that they remain alive, that they have somehow been spared the death that has befallen their counterparts. Consequently, the anguish of the survivor is quickly transformed into a desire for security. ${ }^{22}$

17 Ibid., 34.

18 Ibid.

19 Ibid., 35.

20 Ibid., 36.

21 Ibid.

22 The extreme disciplinary apparatus of the massacre is rarely employed by established states 


\section{Murambi as a Necropolitical Apparatus}

The memorial at Murambi functions as a necropolitical apparatus in the arena of public history and civic education. The Rwandan government's choice to maintain the massacre site, complete with the corpses of the victims, is inappropriate to the proclaimed educative mission of the memorial. When the power structure in Rwanda "continuously refers and appeals to exception, emergency, and fictionalized enemy" 23 via this memorial form, it also betrays a more nefarious understanding of its own authority. The contact that is encouraged between visitor and corpse replicates the experience of survival and, hence, the logic of the survivor as outlined by Mbembe. The sense of threat invoked by the logic of the survivor is, furthermore, antagonistic to the goals of reconciliation, social transformation, and peacebuilding.

Murambi's educative power is derived from its two dominant characteristics which both rely on an over-exposure to the scene of a massacre. The first is the fact that the Ecole Technique Officielle is not a crypt or mausoleum where bodies would commonly be kept. It is a school, a space that is primarily designed for academic learning, where death and tragedy are supposed to be considered abstractly rather than experienced directly. Yet within the classrooms where the massacre took place it is possible to readily access a replicated scene of this exact scenario. Secondly, the abstract consideration of death is further disrupted by the proximity of corpses. Other sites in Rwanda, and elsewhere throughout the world, have also utilized skeletal remains to reinforce the magnitude of a tragedy.

and so may appear irrelevant to the present discussion. However, as Mbembe's essay suggests, numerous strategies replicate the structure of the massacre in less bloody ways. Indeed, his broadly defined "concern is those figures of sovereignty whose central project is not the struggle for autonomy but the generalized instrumentalization of human existence and the material destruction of human bodies and populations" (14). States, no matter how longstanding their authority may be, continue to lean on two strategies that we can identify as necropolitical and which can function separately or cooperatively depending upon the institution. First, in historico-political discourse, an authority will commonly reference the original bloodshed that brought the nation into being or reinforced the mythical narrative that structures one's awareness of nationhood. Such reliance on necropolitics is visible when "power ... continuously refers and appeals to exception, emergency, and fictionalized enemy" (16). This is a common practice across the world, for example in the United States, where the memory of September 11 is evoked as a rationale for restricting immigration, for increasing accessibility to guns, or for waging war on civilian populations throughout the Middle East. The second strategy emerges via disciplinary institutions such as prisons, hospitals, or schools. These focus on the manipulation of bodies and the regulated control over life and death. Such institutions are buoyed by the discourses of death insofar as people willingly defer to the disciplinary authority of the police officer, the doctor, or the teacher. The same narrative justifies the actions of authority and thus serves as a generative force within the community.

23 Ibid., 16. 
But when skeletal remains are on display, the confrontation with death is mediated by the categorization of bones, which disassembles bodies into their structural components - femurs in one pile, skulls in another, etc. Furthermore, bones are perceived as inanimate "things" that can be distanced from the person who formerly used them for support and ambulation. When displaying bones, memorials allow a visitor to understand the magnitude of killing without being forced to directly encounter the taboo of death. Bones, especially disassembled and categorized as they tend to be, indicate a mortal event that has long since passed and have not, themselves, died. A corpse, on the other hand, is a person, fully assembled and obviously dead. At Murambi, the visitor comes into direct contact with dead people, to the extreme limit of being able to touch them.

While the visitor is aware that the death of the other has not been precipitated by the current regime, the logic of survival engendered by this memorial strategy nonetheless encourages a response that is antithetical to the goals of social reconciliation and peace. Rather than encouraging dialogue and an examination of difference, the vision of the corpse compels the visitor to accept the nearest authority, to cling for life to the sovereign who controls the space of killing. Moreover, preserving the massacre as an exhibited artifact is indicative of the state's reliance on displaying power through the inscription of bodies within an economy of death. The dead at Murambi testify to their deaths at the hands of the previous regime; the living who receive this testimony do so under the protection of the current power, which legitimizes its autocratic rule through an allusion to the historical truth of genocide and the continued threat posed by those who perpetrated the crime. Thanks to the complementary walking exhibition, the memorial directs the anguished silence in the presence of corpses toward the sacred appreciation for the heroes who have now liberated the spectators from their own victimhood. In this narrative, there is no question that this sense of security is indissoluble from the Rwandan Patriotic Front (RPF) and the Government of National Unity (GNU) which they initiated and now control.

Thus, Murambi's exhibit allows the Rwandan government to reinforce its authority through the institutionalized apparatus of a massacre site. A rebel militia may stake its own claim to sovereignty in a similar manner, but without the ability to institutionalize death. The GNU distinguishes itself from the rebel militia of the interahamwe by fortifying a story that alludes to their innocence. And it distinguishes itself from its own past as a rebel militia by alluding to its definitive and stifling control over Rwandan society. In short, the visitor is thrust into the logic of survival by the dis-ordering sight of the corpse at the same time that his or her own survival and orderly existence is ensured by the security of the state that claims its own authority over the dead and the story of their death.

It has been suggested that a memorial is optimally employed as an aide 
memoire $;^{24}$ however, instead of providing an arena for communal discourse, the state establishes and bolsters its authority through fear, anguish, and horror at the sight of an original violence. To quote from Mbembe, the Rwandan government uses

history, geography, cartography, and archaeology [to] back the[ir] claims ... Lying beneath the sacred is a constant excavation of missing bones; the permanent remembrance of a torn body hewn in a thousand pieces and never self-same; the limits, or better, the impossibility of representing for oneself an "original crime," an unspeakable death: the terror of the Holocaust. ${ }^{25}$

The legitimacy of RPF rule is established and strengthened through the memory of a sacred crime that persists at the forefront of popular narratives. The memorial presents to the visitor an unspeakable death, both as an historical fact and in a visceral presentation of the slain body. In so doing, Murambi demands that the visitor remain muted and accept the mythologized authority to which both the story and the bodies testify. The memorial is effective in this register, for who would dare speak out against corpses? Whosoever musters enough courage to say anything at all would be hard-pressed to challenge the authority of the dead. The fact of their death, to which a corpse cannot help but convincingly attest, is the steadfast evidence in support of the mythologized authority of the modern state.

What Mbembe points to, and what I am arguing here more directly, is that establishing and strengthening political authority via this mechanism constitutes a politics that is antagonistic to sustainable peace. As the Italian thinker of biopolitics Roberto Esposito explains:

At the moment when the democratic individual, afraid not to know how to defend the particular interests that move him, ends up surrendering "to the first master who appears," the itinerary will already be set in motion, one not so different from another which will push biopolitics nearer to its own opposite, that of thanatopolitics: the herd, opportunistically domesticated, is already ready to recognize its willing shepherd. ${ }^{26}$

Murambi follows a model that founds itself in the fear and anguish of death. The visitor-survivor becomes domesticated to an order that continues to preserve and expose the death of the other; the same order holds the death of the survivor in abeyance. Such a strategy does not enable the visitor to process the historical event on his or her own terms. Instead, the methodology over-determines the lesson at hand. It negates the space for both appropriable reflection and pro-

24 Paul Williams, Memorial Museums: The Global Rush to Commemorate Atrocities (New York: Berg Press, 2007), 157.

25 Mbembe, "Necropolitics," 27.

26 Roberto Esposito, Bíos: Biopolitics and Philosophy, translated by Timothy Campbell (Minneapolis: University of Minnesota Press, 2008), 76-77. 
ductive discourse between citizens. The latter of these exercises is, in fact, discouraged by the heightened sense of prohibition generated by the threat of death. At the same time, it provides an immediate solution to one's sense of vulnerability in the figure of the government.

This approach to commemorating the past does not encourage a brighter, more peaceful, more stable future. On the contrary, Murambi animates a logic that is more closely aligned with genocide. It generates alignment and produces consent through a heightened sense of taboo. The fear and vulnerability accompanying an encounter with death replicates the model of control utilized by agents staking their sovereign claim to a territory. This disciplinary apparatus resembles closely those who encourage a civilian population to abide an authoritative or totalitarian schema. It appears, then, that such mechanisms function as tools of control rather than progressive change. This form of prohibition-focused commemorative education must therefore be carefully reconsidered if the genuine aim is to transform society in a positive manner. We must take seriously the task of generating peace through education and align methodology with the behavior that we wish to replicate within our broader communities.

\section{Bibliography}

Bataille, Georges. Erotism: Death and Sensuality. Translated by Mary Dalwood. San Francisco: City Lights, 1986.

Doughty, Kristin. "Memorials, Human Remains and Controversy in Post-Genocide Rwanda." Anthropology News: In Focus, September 2011, http://www.anthropologynews.org. Accessed 11 November, 2015.

Esposito, Roberto. Bíos: Biopolitics and Philosophy. Translated by Timothy Campbell. Minneapolis: University of Minnesota Press, 2008.

Hope Magazine. "18th Genocide Commemoration 'Learning from our history to build a bright future," http://www.hope-mag.com/news.php?option $=$ lnews \& $\mathrm{ca}=1 \& \mathrm{a}=90$. Accessed 18 November, 2012.

Kagame, Paul. "Speech by H.E. Paul Kagame at the 18th Commemoration of the Genocide Against the Tutsi." 7 April, 2012. http://www.paulkagame.com/2010/index.php?option= com_content\&view=article\&id=630\%3Aspeech-by-he-paul-kagame-president-of-therepublic-of-rwanda-at-the-18th-commemoration-of-the-genocide-against-the-tutsiamahoro-stadium-7-april-2012\& catid $=34 \% 3$ Aspeeches $\&$ Itemid $=56 \&$ lang $=$ en. Accessed 15 November, 2012.

Mbembe, Achille. "Necropolitics." Translated by Libby Meintjes. Public Culture 15, no. 1 (2003): 11-40.

Sontag, Susan. Regarding the Pain of Others. New York: Picador, 2003.

Williams, Paul. Memorial Museums: The Global Rush to Commemorate Atrocities. New York: Berg Press, 2007. 
Open-Access-Publikation im Sinne der CC-Lizenz BY 4.0

(c) 2018, V\&R unipress $\mathrm{GmbH}$, Göttingen 


\section{Insights from Practice: Lessons from Holocaust Education for the Transitional Justice Classroom}

\section{Introduction}

Educating about and for transitional justice raises numerous questions for educators: At what age and in what depth is it appropriate to discuss human atrocities with young people? How should the topic of transitional justice be approached in the classroom? Which cognitive, affective, and behavioral learning outcomes are desired? Which pedagogies will best conduce to such learning? How should the gruesome facts of human violence and sensitivities related to conflicting identities, contested memories, and competing narratives about the recent past be handled in the classroom? What training and support do transitional justice educators especially those native to the conflict context - require? And how should the "success" of transitional justice education be measured?

Being so new a field, the answers to such questions are not easily forthcoming. A growing recognition of the need for broad-based engagement in transitional justice contexts thus compels the search for relevant precedents that could help inform the design and implementation of transitional justice education. A review of the literature reveals that some precedents may be found in the fields of peace education, human rights education, and conflict-sensitive education which, over several decades, have offered unique responses to the human and institutional challenges of societies affected by conflict, injustice, and violence. At times conflated, these three approaches represent distinct, if complementary, educational agendas. While they share common values, they also vary considerably in their approaches to teaching about histories of human atrocity. In this chapter I examine these precedents with the aim of identifying practice-based lessons that can advance educational thinking and practice in transitional justice contexts.

The chapter begins by highlighting shifts in the relationship between transitional justice, outreach, and education over the past 20 years. It then compares the main aims and methods of peace education, human rights education, and conflict-sensitive education with those of transitional justice education. I subsequently argue that a closer and more productive precedent for transitional 
justice education may be found in the field of Holocaust education. Reviewing research on Holocaust education practice, this chapter brings into focus a number of practical, pedagogical, political, ethical, and generational considerations for teachers, curriculum developers, and policymakers intending to support transitional justice education initiatives. The chapter concludes with six guidelines for approaching histories of atrocity in the classroom.

\section{The Aims, Limitations, and Growing Reach of Transitional Justice}

Societies grappling with recent histories of atrocity and mass human rights violations may undertake a variety of transitional justice (TJ) measures "to uncover, address, and redress the wrongs of the past." ${ }^{1}$ These measures can include, but are not limited to, truth commissions, criminal prosecutions, reparations to victims, lustration processes, other types of institutional reform, and memorialization initiatives. Transitional justice processes aim to establish an accurate historical record of the violations committed, to fight against the impunity of perpetrators, to compensate victims, to address grievances among the affected communities, and to prevent such crimes recurring in the future. Transitional justice is a sensitive, complex, and often prolonged undertaking whose political, moral, and social implications extend beyond the individuals directly involved, and indeed beyond the immediate generations associated with the atrocities under scrutiny. Unsurprisingly, many societies with histories of mass human rights abuses demonstrate ambivalence towards transitional justice mechanisms due to the conflict, pain, and frustration these mechanisms can bring to the surface. ${ }^{2}$ Indeed, the success of transitional justice measures in facilitating a sense of truth, justice, and reconciliation can be profoundly affected by both how they are conducted and how they are perceived by the population. ${ }^{3}$

Transitional justice is also a relatively new field of intervention, and research has found that its measures can face a number of limitations. In some cases, they may be perceived as distant from the lives of ordinary citizens and as increasing,

1 Julia Paulson, (Re)Creating Education in Postconflict Contexts: Transitional Justice, Education, and Human Development (New York: International Center for Transitional Justice, 2009), 4.

2 For example, Indonesia: http://www.mei.edu/content/problem-transitional-justice-post-su harto-indonesia. See also on Bosnia-Herzegovina (http://ijtj.oxfordjournals.org/content/ early/2016/03/08/ijtj.ijw005.abstract), Egypt (http://intpolicydigest.org/2011/10/16/failedtransitional-justice-in-egypt/), Iraq (https://www.icrc.org/eng/assets/files/other/irrc-869_ stover.pdf), Nepal (https://www.ictj.org/news/ictj-program-report-nepal), and Sri Lanka https://www.ictj.org/news/sri-lanka-break-cycle-impunity-promises-need-be-kept), all accessed 7 February 2018.

3 Clara Ramírez-Barat and Roger Duthie, Education and Transitional Justice: Opportunities and Challenges for Peacebuilding (New York: ICTJ, 2015), 1. 
rather than decreasing, social division. ${ }^{4}$ Transitional justice processes may be perceived as poorly adapted to cultural expectations of accountability and forgiveness ${ }^{5}$, or as benefiting international actors more than the local surviving populations. ${ }^{6}$ Critics have also expressed concern over failures of transitional justice mechanisms to address structural inequalities that provided the backdrop for past crimes ${ }^{7}$; to achieve a common understanding of the past ${ }^{8}$; to shift hostile attitudes and conflicting collective narratives ${ }^{9}$; to address the grievances of victims ${ }^{10}$; and to facilitate the population's healing of psychological and social wounds. ${ }^{11}$ Analysts such as Gray ${ }^{12}$ are concerned that without a host of complementary policies and measures, transitional justice efforts may be ineffective in preventing future violence.

4 See, for example, Erin Daly, "Transformative Justice: Charting a Path to Reconciliation," International Legal Perspectives 12, no. 1-2 (2002); Priscilla B. Hayner, Unspeakable Truths: Facing the Challenge of Truth Commissions, 2nd ed. (New York: Routledge, 2011 [2001]); Alexander Laban Hinton, ed., Transitional Justice: Global Mechanisms and Local Realities after Genocide and Mass Violence (New Brunswick, N.J.: Rutgers University Press, 2010), and Hugo van der Merwe, Victoria Baxter, and Audrey R. Chapman, eds., Assessing the Impact of Transitional Justice: Challenges for Empirical Research (Washington, DC: US Institute of Peace Press, 2009).

5 C. L. Sriram, "Justice as Peace? Liberal Peacebuilding and Strategies of Transitional Justice," in The Liberal Peace and Post-War Reconstruction - Myth or Reality, edited by Roger MacGinty and Oliver Richmond (New York and Oxon: Routledge, 2009).

6 R. M. Hayden, "What's reconciliation got to do with it? The International Criminal Tribunal for the Former Yugoslavia (ICTY) as Antiwar Profiteer," Journal of Intervention and Statebuilding 5, no. 3 (2011): 313-330, here, 313; Bojan Bilić, "A Concept that is Everything and Nothing: Why not to Study (Post-) Yugoslav Anti-War and Pacifist Contention from a Civil Society Perspective," Sociologija LIII, no. 3 (2011): 297-322, here, 305 and 309; Jelena Subotic, Hijacked Justice: Dealing with the Past in the Balkans (Ithaca/New York: Cornell University Press, 2009), 45-46.

7 Hayner, Unspeakable Truths; Lisa J. Laplante, “Transitional Justice and Peace Building: Diagnosing and Addressing the Socioeconomic Roots of Violence through a Human Rights Framework," International Journal of Transitional Justice 2, no. 3 (2008): 331-355; Fiona C. Ross, "An Acknowledged Failure: Women, Voice, Violence, and the South African Truth and Reconciliation Commission," in Localizing Transitional Justice: Interventions and Priorities after Mass Violence, edited by Rosalind Shaw and Lars Waldorf (Stanford: Stanford University Press, 2010), 69-91.

8 Roland Kostić, "Transitional Justice and Reconciliation in Bosnia-Herzegovina: Whose Memories, Whose Justice?" Sociologija 54, no. 4, (2012): 649-666; here, 658.

9 Janine N. Clark, "The Limits of Retributive Justice: Findings of an Empirical Study in Bosnia and Hercegovina," Journal of International Criminal Justice 7, no. 3 (2009): 463-487.

10 Hayner, Unspeakable Truths.

11 Judy Barsalou, Trauma and Transitional Justice in Divided Societies. Special Report (Washington, D.C.: USIP, 2008); Bronwyn A. Leebaw, "The Irreconcilable Goals of Transitional Justice," Human Rights Quarterly 30, no. 1 (2008): 95-118; and Eric Stover and Harvey M. Weinstein, eds., My Neighbour, My Enemy: Justice and Community in the Aftermath of Mass Atrocity (Cambridge: Cambridge University Press, 2004), 365-368.

12 David C. Gray, "An Excuse-Centered Approach to Transitional Justice," Fordham Law Review 74, no. 5 (2006). 
Growing awareness of these limitations over the past 20 years has led to shifts in how the relationship between transitional justice processes and the general public is managed. The International Criminal Tribunal of the former Yugoslavia (ICTY) offers an illustrative case in this regard. Established in 1993, the ICTY "initially had no outreach activities in the languages of the affected populations." 13 Responding to a "huge deficit of acceptance," the ICTY set up its Outreach programme in 1999 with the aim "to build direct channels of communication with affected communities, in order to raise awareness of the justice process and promote understanding of its work."14 "Outreach" as defined by the International Criminal Court is:

[The] process of establishing sustainable, two-way communication between the Court and communities affected by the situations that are subject to investigations or proceedings, and [of] promot[ing] understanding and support of the judicial process at various stages, as well as the different roles of the organs of the ICC. Outreach aims to clarify misperceptions and misunderstandings and to enable affected communities to follow trials. ${ }^{15}$

The ICTY began disseminating information locally about its activities in the form of press releases, case reports, transmissions of court proceedings, and presentations to key audiences. ${ }^{16}$ By 2004 newer forms of dialogic engagement, intended to "bridge the gap" with transitional justice "stakeholders" (i.e. those "most affected by crimes"), were also launched. ${ }^{17}$ Through presentations and workshops with local community leaders, journalists, victims, returnees, legal professionals, law enforcement personnel, scholars and other members of the public, the Court aimed to increase community-level understanding of the nature, purposes, challenges and milestones of the criminal justice process. As the need was recognized, the UN General Assembly encouraged outreach programs

13 Elizabeth Cole, "Transitional Justice and the Reform of History Education," International Journal of Transitional Justice 1, no. 1 (2007): 115-137.

14 Quoted from Martina Fischer and Ljubinka Petrović-Ziemer, Dealing with the Past and Peacebuilding in the Western Balkans (Osnabrück: Deutsche Stiftung Friedensforschung, 2015), 16, and Ramírez-Barat, Making an Impact, respectively. See also Laurel E. Fletcher and Harvey M. Weinstein, "A World unto Itself? The Application of International Justice in the Former Yugoslavia," in My Neighbor, My Enemy: Justice and Community in the Aftermath of Mass Atrocity, edited by Eric Stover and Harvey M. Weinstein (Cambridge: Cambridge University Press, 2004).

15 See the ICC website: https://www.icc-cpi.int/en_menus/icc/structure\%20of\%20the\%20 court/outreach/Pages/outreach.aspx, accessed 7 February 2018.

16 See the ICTY outreach program archive: http://www.icty.org/en/outreach/activities-archive/ 1999, accessed 7 February 2018.

17 ICTY website: http://www.icty.org/en/outreach/bridging-the-gap-with-local-communities, accessed 7 February 2018. See also Clara Ramírez-Barat, Making an Impact: Guidelines on Designing and Implementing Outreach Programs for Transitional Justice (New York: International Center for Transitional Justice, 2011). 
to develop age-appropriate resources for children and youth. ${ }^{18}$ The main objective was to help prevent future atrocities by raising young people's awareness of their historical occurrence, criminal nature, negative impact on society and the world, and of the importance of redress and prevention. ${ }^{19}$ The ICTY Outreach office in Sarajevo gradually followed suit, extending its outreach efforts to the education sector in 2011. Thousands of university level and secondary school students across former Yugoslavia have now attended ICTY Outreach guest lectures and non-formal education workshops. ${ }^{20}$ It should be noted, however, that despite this progress such opportunities often remain an elite privilege of small groups of student delegates rather than an inclusive process reaching all young people in the affected countries through normal classroom lessons.

\section{Transitional Justice Education}

Until now, the little existing literature on transitional justice and education has framed these spheres of activity as appendiary, rather than necessary, to the other. Recent developments are, however, moving beyond the notion of outreach as the public information appendage to transitional justice measures, towards a fuller notion of "education for transitional justice" or what I will identify here as "transitional justice education." This shift anticipates a wider form of public engagement in which institutions of socialization - principally schools - are regarded as necessary partners for ensuring that transitional justice processes succeed in facilitating the transition from social and structural violence to justice and peace. ${ }^{21}$ Through this lens, transitional justice education aims not only to

18 See, for example, student-oriented materials developed by the ICTR at: http://www.un.org/ en/preventgenocide/rwanda/education/education.shtml. For an extended discussion of international practices and recommendations regarding print, audio-visual, and interactive resources and activities for children, youth, and teachers, see also Ramírez-Barat, Making an Impact.

19 See the 2005 UN General Assembly Resolution A/RES/60/225, Art. 4, which "urges Member States to develop educational programmes that will inculcate future generations with the lessons of the genocide in Rwanda in order to help to prevent future acts of genocide." And Art. 5, which "requests the Secretary-General to establish a programme of outreach entitled 'The Rwanda Genocide and the United Nations' as well as measures to mobilize civil society for Rwanda genocide victim remembrance and education, in order to help to prevent future acts of genocide."

20 ICTY Outreach Programme website: http://www.icty.org/en/outreach/youth-outreach, accessed 7 February 2018.

21 Cole, "Transitional Justice and the Reform of History Education"; Ramírez-Barat and Duthie, Education and Transitional Justice; Ramírez-Barat, Making an Impact, and Clara RamírezBarat, Engaging Children and Youth in Transitional Justice Processes: Guidance for Outreach Programs (New York: ICTJ, 2012). 
strengthen public confidence in the necessity and legitimacy of transitional justice measures, but also to cultivate shared responsibility and capacity among individuals, institutions and communities to build sustainable peace characterized by open recognition of past wrongs, by social inclusion and dialogue, critical citizenship, justice, and reconciliation. Thus, from teaching about transitional justice in primarily informational terms, schools may increasingly encourage students to develop and exercise agentic capacities related to and supportive of social and structural transformation. Transitional justice education is emerging from the recognized need to further transitional justice goals through inclusive engagement at the community and institutional levels.

The earliest conceptualization of transitional justice education was put forward by Guinn as a tailored approach to human rights education. He wrote: "[A]n opportunity has commonly been lost to tailor educational programming to address the special needs of transitional societies. Specifically, human rights education in post-conflict environments must address three broad goals: correcting social dysfunction; contextualizing truth; and establishing normative values [my emphasis]."22

By "correcting social dysfunction" he means counteracting the social impacts of rights-abusive regimes which tend to create a passive and easily manipulable citizenry. He also means breaking down the demonizing and dehumanizing constructions of the enemy Other. By "establishing normative values" he means a "primary effort must be to re-establish the humanity, human dignity, and worth of all citizens." And by "contextualizing truth" Guinn explains:

One of the ways victims are victimized by an abusive regime is that their stories are hidden ... The magnitude of the crime [is] denied ... In order to understand what has happened, the state must not only assemble the raw data of facts, but must find ways to provide normative context for those facts. The abuses ... must be communicated in ways that identify not only what happened, but why - and why it was wrong.

Guinn argues that "the first objective" of transitional justice education "must be to re-establish the human connection among all citizens and 'restore the capacity of society to be moved'." Programming "designed to reach out to all of the members of the society: abusers and abused alike" must re-awaken the population's senses, re-establish their connection to society and their capacity to act as responsible agents. This normative framing of transitional justice education is one dimension that distinguishes it from simple public information strategies or history education.

Given the newness of the field, transitional justice education remains a site of

22 David E. Guinn, "Human Rights Education: The Third Leg of Post-Conflict/Transitional Justice," Human Rights and Human Welfare: Working Papers, no. 42 (2005), 17 and, below, 19-20. 
experimentation. While there is a growing base of teaching materials in certain contexts, there is still little research or evaluation on how it is practiced, what its goals are, or how to measure its impact. We know very little about how teachers implement it, which pedagogical techniques are most effective, what challenges educators face, how students perceive these lessons and materials, and what understandings, attitudes, and behaviours students retain from such learning.

In terms of certain basics, we can say that transitional justice education is most likely to occur within the first few decades of a nation's violent past, although it can be delayed by generations. ${ }^{23}$ It tends to involve teachers and students who have a living memory of the conflict and its associated crimes, and it is distinguished by its focus on exploring the recent past from a critical human rights perspective. Transitional justice education can be approached narrowly, in the sense of the outreach programmes mentioned above, or it can be approached broadly with the aim of reaching beyond those immediately affected to engage successive generations of children and youth through the formal education system and a range of institutions and structures. ${ }^{24}$ The purpose of the latter approach is to generate broad-based societal awareness of the facts and consequences of the violent conflict on all sides, and to generate a shared commitment to uncovering, acknowledging, addressing, and ultimately preventing such atrocities in a bid to strengthen a society's capacity for peace and social cohesion.

Recent developments in discourses on transitional justice and education draw on human rights and conflict-sensitive education frameworks to extend the mandate of transitional justice to include a redress of structural inequalities in education systems, calling for a "transitional justice lens" or "approach" to holistic education reform. ${ }^{25}$ It is productive to adopt these various lenses in order to better inform the recommendations of transitional justice mechanisms in

23 See, for example, initiatives related to the cultural genocide of indigenous peoples in Australia: http://www.reconciliationsa.org.au/assets/media/files/Education\%20Packs/Stolen Generations.pdf and http://www.racismnoway.com.au/teaching-resources/factsheets/index. html, as well as in Canada: http://www.rcinet.ca/en/2015/09/13/truth-and-reconciliation-ineducation-a-beginning, http://www.theglobeandmail.com/news/british-columbia/new-bcschool-curriculum-will-have-aboriginal-focus/article25003962/ and https://www.thestar. com/opinion/commentary/2015/06/03/education-the-first-step-to-reconciliation.html, all accessed 7 February 2018.

24 Karen Murphy, Educational Reform through a Transitional Justice Lens: The Ambivalent Transitions of Bosnia and Northern Ireland (New York: ICTJ, 2015), 1.

25 "A transitional justice approach to education reform requires first to understand and acknowledge the role that education played in fuelling or nurturing the previous conflict (including access to education, cultural and linguistic exclusion from the curricula or the use of educational means to promote repression and manipulate students), to avoid some of the mistakes made in simply recreating education as it was." Ramírez-Barat and Duthie, Education and Transitional Justice, 6. 
terms of structural reforms and reparations to victims. Another distinguishing contribution of "transitional justice education" is arguably this new field's unique concern with assisting new generations of students to confront their own recent histories of mass violence in ways that facilitate their society's transition to truth, justice, peace, and reconciliation.

In this light, transitional justice education can be conceived of as both a subject and a pedagogy that is specific in terms of historical time and place, and that forms part of a given society's evolving collective narrative, identity, and purpose. It is necessarily rooted amid particular peoples and within relatively clear temporal and geographical contexts. It entails familiarization with specific past acts of violence, terror, dehumanization, abuses of power, torture, deprivation, and death. It confronts true accounts of human vulnerability and cruelty, and it must be realistic in its portrayal of the often protracted and inevitably limited processes of tracing and holding accountable those responsible for the worst of these crimes. It is a subject that can evoke strong feelings in both teachers and students. Depending upon the emphasis placed on the perpetrators versus the victims of atrocities, transitional justice education may or may not touch upon issues of survival, trauma, healing, and reconciliation. In all cases, transitional justice education deals with contested memories and narratives, as well as with issues of power, powerlessness, and the quest for agency. These challenges and the questions they raise concerning classroom practice lead us to search for relevant precedents that could guide thinking and practice in the new field of transitional justice education.

\section{Educational Responses to Violent Conflict}

As already mentioned, there are several precedents in academic, practitioner, and policy literature on educational responses to violent conflict that may be useful to the development of transitional justice education. These include peace education, human rights education, and, most recently, conflict-sensitive education. Each attempts, in different ways, to support violence prevention and promote justice and sustainable peace, and they are increasingly recommended by international organizations for inclusion in peacebuilding and development strategies. ${ }^{26}$ While occasionally conflated, they represent distinct, if complementary, educational agendas which vary considerably in their approaches to

26 UN General Assembly, Transforming our World: The 2030 Agenda for Sustainable Development (New York: UN, 2015); UNESCO, The Hidden Crisis: Armed Conflict and Education. EFA Global Monitoring Report (New York: UNESCO, 2011); UNICEF Education Section, Proposal on Peacebuilding and Education presented to the Ministry of Foreign Affairs Government of the Netherlands (New York: UNICEF, 2011). 
teaching about the recent past in post-conflict contexts. Each is, thus, of varying relevance to the classroom practice of transitional justice education. A brief overview of each is provided here.

Peace education has the longest history as an educational response to violent conflict. ${ }^{27}$ It dates back to the early $20^{\text {th }}$ century and has developed significantly following the creation of UNESCO in the aftermath of WWII. ${ }^{28}$ Especially during the UN's 2001-2010 International Decade for a Culture of Peace and Non-violence for the Children of the World, international peace education practice came to focus on fostering "cultures of peace" through the learning of values, attitudes, skills, and behaviours, such as respect for diversity, tolerance, and mutual understanding, non-violent conflict resolution, participatory decision-making, and civic engagement. ${ }^{29}$ Unlike transitional justice education, peace education practice rarely examines the violent past of a given society except to create a justificatory backdrop for peace learning or to underscore exemplary peacepromoting behaviour. While peace education sometimes incorporates a social justice emphasis on identifying and overcoming barriers to equality, protection, and sustainable well-being, most programs of peace education pay little attention to specific histories of violence. Exceptionally, approaches which emphasize psychosocial dimensions of peacebuilding may examine context-specific causes and effects of violence as part of promoting intergroup contact, healing, and reconciliation. ${ }^{30}$ But these tend not to include a close examination of the actors and events that have led to human atrocities.

27 Peace education came into particular focus in 1994 at UNESCO's $44^{\text {th }}$ Session of the International Conference on Education which produced the 1995 Integrated Framework of Action on Education for Peace, Human Rights and Democracy. This was followed by concerted international engagement with peace education during the 2001-2010 United Nations International Decade for a Culture of Peace and Non-violence for the Children of the World (A/ $\mathrm{RES} / 53 / 25)$.

28 James S. Page, "The United Nations and Peace Education," in Encyclopedia of Peace Education (Charlotte, NC: Information Age Publishing, 2008).

29 Susan Fountain, Peace Education in UNICEF, Working Paper, Education Section (New York: UNICEF, 1999), 1-52. Retrieved from http://www.unicef.org/education/files/PeaceEduca tion.pdf, accessed 7 February 2018. For other relevant literature on peace education, see: Monisha Bajaj, ed., Encyclopedia of Peace Education (Charlotte, NC: Information Age Publishing, 2008); Ian M. Harris and Mary Lee Morrison, Peace Education, $3^{\text {rd }}$ ed. (Jefferson, NC: McFarland, 2012); David W. Johnson and Roger T. Johnson, "Essential Components of Peace Education," Theory into Practice 44, no. 4 (2005): 280-292; Claire McGlynn et al., Peace Education in Conflict and Post-Conflict Societies: Comparative Perspectives (New York: Palgrave, 2009); Betty Reardon, Comprehensive Peace Education: Educating for Global Responsibility (New York: Teachers College Press, 1988); Gabriel Salomon and Baruch Nevo, Peace Education: The Concept, Principles, and Practices Around the World (London: Psychology Press, 2005); and Christoph Wulf, ed., Handbook on Peace Education (Frankfurt: International Peace Research Association, 1974).

30 See, for example, the Education for Peace Program in Bosnia and Herzegovina, and H.B. 
Human rights education (HRE) has been promoted internationally by $\mathrm{UNESCO}^{31}$ and other organizations since the 1960 s and especially during the 1995-2004 UN Decade for Human Rights Education. ${ }^{32}$ Its main purpose is to promote awareness about human rights frameworks to combat and prevent violations. The normative agenda underlying human rights education stems from numerous international human rights conventions to which signatory nations are obliged..$^{33} \mathrm{~A}$ core component of HRE is familiarizing students with these conventions. Often HRE also focuses on historical and contemporary examples of human rights violations with the aim of generating broad-based awareness of and a sense of responsibility towards protecting human rights to survival, dignity, well-being, and justice, among others. Students are trained to recognize discriminatory behaviours, and are encouraged to live by and promote values of tolerance, equality, and inclusive democratic participation. ${ }^{34}$ Examples of past human rights abuses are cited in lessons in order to highlight a given normative principle but, unlike transitional justice education, such examples are not necessarily connected to students' own (local or national) histories of violence. Rarely are gross atrocities studied in depth or problematized in their complexity. ${ }^{35}$

Danesh, "Creating a Culture of Healing in Multiethnic Communities: An Integrative Approach to Prevention and Amelioration of Violence-induced Conditions." Journal of Community Psychology 36, no. 6 (2008): 814-832.

31 See, in particular, UNESCO's 1960 Convention against Discrimination in Education, 1974 Recommendation concerning Education for International Understanding, Co-operation and Peace and Education relating to Human Rights and Fundamental Freedoms, and 1995 Declaration and Integrated Framework of Action on Education for Peace, Human Rights and Democracy.

32 UN Resolution (A/RES/49/184). For relevant literature on human rights education, see Ali A. Abdi and Lynette Shultz, eds., Educating for Human Rights and Global Citizenship (Albany: SUNY Press, 2009); George J. Andreopoulos and Richard Pierre Claude, eds., Human Rights Education for the Twenty-First Century (Philadelphia: University of Pennsylvania Press, 1997); Tracey Holland, "Human Rights Education in Peace-Building: A Look at Where the Practice has Come From, and Where it Needs to Head," Human Rights \& Human Welfare 62 (2010); Ulrike Niens and Jacqueline Reilly, "Education for Global Citizenship in a Divided Society? Young People's Views and Experiences," Comparative Education 48, no. 1 (2012): 103-118; and Felisa Tibbitts and William R. Fernekes, "Human Rights Education," in Teaching and Studying Social Issues: Major Programs and Approaches, edited by Samuel Totten and Jon E. Pedersen (Charlotte, NC: Information Age Publishing, 2011).

33 See the Office of the United Nations High Commissioner for Human Rights (OHCHR) website for a list of core HR instruments: http://www.ohchr.org/EN/ProfessionalInterest/ Pages/CoreInstruments.aspx, accessed 7 February 2018.

34 See Commission on Human Rights Resolution 2004/71 (21 April 2004), preambular paragraph 4.

35 Margherita Rendel, "Some Problems in Teaching Human Rights," in Human Rights, Education, and Global Responsibilities, edited by James Lynch, Celia Modgil, and Sohan Modgil (London: The Falmer Press, 1992), 151-162. 
Conflict-sensitive education (CSE) is the most recent international response to violent conflict within the field of education. ${ }^{36}$ Unlike previous approaches, CSE is not a classroom program or resource, nor is it associated with specific topics or curricula. Rather, as promoted by the Inter-Agency Network of Education in Emergencies, CSE is an analytical framework that helps planners reflect on and avoid conflict-aggravating educational policies and practices. ${ }^{37}$ Conflictsensitive education recognizes that education policies and provision can both aggravate and mitigate conflict. ${ }^{38}$ It thus provides a generic set of principles for planning and provision, such as equity, inclusion, and "do no harm" in order to minimize the negative effects and maximize the positive impacts of education on conflict-affected environments. It can usefully inform short- and medium-term educational planning and provision, and may be used to identify educational inequalities and injustices that transitional justice measures may seek to redress. A conflict-sensitive analysis can offer transitional justice practitioners a broader understanding of how grievances within and between communities are aggravated not only by the manner in which histories of atrocity are covered in classroom teaching, but also by ongoing discrimination within educational structures including inequalities of recognition, representation, and redistribution. ${ }^{39}$ On its own, however, CSE provides no substantive guidance for engaging classrooms in coming to terms with the past or for laying the foundations for future reconciliation.

36 Conflict-sensitivity became an international development priority in the mid-2000s (see DFID benchmarking paper: http://local.conflictsensitivity.org/wp-content/uploads/2015/ 05/CSA-Benchmarking-paper-full.pdf), accessed 7 February 2018. As awareness of the role of education in conflict grows, conflict-sensitive approaches to education have been increasingly mainstreamed. For relevant literature on CSE, see Kenneth D. Bush and Diana Saltarelli, The Two Faces of Education in Ethnic Conflict: Towards a Peacebuilding Education for Children (New York: UNICEF/Innocenti, 2000); INEE, Guidance Note on Conflict Sensitive Education (Geneva: Inter-Agency Network for Education in Emergencies, 2013); and UNESCO, The Hidden Crisis: Armed Conflict and Education. EFA Global Monitoring Report (New York: UNESCO, 2011).

37 INEE Guidance Note on Conflict Sensitive Education.

38 Bush and Saltarelli, The Two Faces of Education in Ethnic Conflict.

39 Nancy Fraser, "Social Justice in the Age of Identity Politics: Redistribution, Recognition and Participation," in Redistribution or Recognition? A Political-Philosophical Exchange, edited by Nancy Fraser and Axel Honneth, (London: Verso, 2003), 7-109; Mario Novelli, Mieke T.A. Lopes Cardozo, and Alan Smith, A Theoretical Framework for Analysing the Contribution of Education to Sustainable Peacebuilding: 4Rs in Conflict-Affected Contexts (New York: UNICEF Consortium on Education and Peacebuilding, 2015); UNICEF, Case Study Guidance and Template: Peacebuilding Education and Advocacy (PBEA) Programme in Conflict-Affected Contexts (New York: UNICEF, 2012). 


\section{A Closer Precedent: Holocaust Education}

This chapter argues that, in comparison to the above mentioned approaches, Holocaust education offers a much closer precedent for the emerging field of transitional justice education based on its direct engagement with histories of atrocity and its normative orientation. Born to prevent ignorance and denial of Nazi crimes against humanity and to make understood and to avert the processes by which societies are led to mass violence, Holocaust education has, over the past 60 years, had a significant impact on curricular, textbook, and pedagogical reforms internationally. ${ }^{40}$ Arguably, Holocaust-themed unit and lesson frameworks, instructional strategies, activities, teaching supports, and learning resources offer a vast reservoir of educational theory and practice that may be adapted for transitional justice contexts. However, despite the vast literature on Holocaust education, its insights into effective strategies for and challenges emerging from teaching about histories of atrocity have only scarcely entered into discourses on education for transitional justice and post-violence peacebuilding.

Like transitional justice education, Holocaust education has both specific and general aims. In the narrow sense, it aims to inform young generations about the systematic actions of the Nazi regime and its allies during the period of 1933 to 1945 to eradicate European Jewry and other minority groups, and aims to keep the memory of these victims and the wrongs of these perpetrators alive. In this respect, Holocaust education is a form of memorialization. More generally, Holocaust education aims to inoculate successive generations against the risks of unbridled discrimination and human rights abuses by promoting awareness, acceptance of diversity, solidarity, a sense of responsibility, and moral courage to defend human dignity and equality. To do so, Holocaust education engages deeply with histories of atrocity, as transitional justice education might do, in order to critically examine the roles that individuals, institutions and societies have played, then and today, in the occurrence and prevention of abuses.

The International Holocaust Remembrance Alliance (IHRA) ${ }^{41}$ expresses the broader aims of Holocaust education as follows:

$40 \mathrm{Liz}$ Airton, Literature Review on Genocide Pedagogies and Curricula 1980 to Present (Montreal: Life Stories in Education Working Group, 2009), retrieved from www.lifestories montreal.ca, accessed 7 February 2018; Patricia Bromley and Susan Garnett Russell, "The Holocaust as History and Human Rights: A Cross-national Analysis of Holocaust Education in Social Science Textbooks, 1970-2008," Prospects 40 (2010): 153-173; Peter Carrier, Eckhardt Fuchs, and Torben Messinger, The International Status of Education about the Holocaust: A Global Mapping of Textbooks and Curricula (New York: UNESCO/GEI, 2015).

41 Formerly the Task Force for International Cooperation on Holocaust Education, Remembrance and Research (ITF). 
A thorough study of the Holocaust helps students think about the use and abuse of power, and the roles and responsibilities of individuals, organisations and nations when confronted with human rights violations. It can heighten awareness of the potential for genocide in the contemporary world. Study of the Holocaust assists students in developing an understanding of the ramifications of prejudice, racism, anti-Semitism and stereotyping in any society. It helps students develop an awareness of the value of diversity in a pluralistic society and encourages sensitivity to the positions of minorities. The Holocaust provides a context for exploring the dangers of remaining silent and indifferent in the face of the oppression of others. As students gain insight into the many historical, social, religious, political and economic factors that cumulatively resulted in the Holocaust, they gain awareness of the complexity of the historical process and a perspective on how a convergence of factors can contribute to the disintegration of democratic values. Students come to understand that it is the responsibility of citizens in a democracy to learn to identify the danger signals and to know when to react. ${ }^{42}$

Holocaust education is thus conceptualized as having a "civilizing influence" on society. ${ }^{43}$ Driving this approach is the notion that critical historical consciousness leads to collective enlightenment. ${ }^{44}$ Holocaust education is regarded not only as a site for transmitting historical knowledge, but also as a site for socializing new generations both morally and politically.

Many of the cognitive, affective, and behavioral learning objectives commonly associated with Holocaust education resonate with broader transitional justice goals. Among the most salient are:

- To raise awareness that human atrocities have occurred in the recent past and continue to occur in today's world;

- To understand the root causes of genocide and other atrocities, which are social-psychological, cultural, and political in nature. Important themes in this area include "the use and abuse of power, and the roles and responsibilities of individuals, organisations and nations when confronted with human rights violations"; 45

- To understand the effects of genocide and other atrocities on the communities and individuals concerned, as well as on world history and culture;

- To deter future crimes against humanity, by helping people recognize that genocide is a criminal act in international military and humanitarian law,

42 ITF, 2010 Education Working Group Paper on the Holocaust and Other Genocides, 4.

43 Paul Salmons, "Teaching or Preaching? The Holocaust and Intercultural Education in the UK," Intercultural Education 14, no. 2 (2003): 139-149.

44 Wolfgang Meseth and Matthias Proske, "Mind the Gap: Holocaust Education in Germany, between Pedagogical Intentions and Classroom Interactions," Prospects 40 (2010): 201-222.

45 Salmons, "Teaching or Preaching?" 
informing the future "command generation" of the criminal status of these acts and to imbue them with a sense of moral duty to protect populations; ${ }^{46}$

- To process personal and collective grief over the losses, injustices, and indignities that were endured; ${ }^{47}$

- To expand the sphere of moral belonging and empathize with victims of injustice in other contexts;

- To promote tolerance of diversity and pluralism among diverse groups in contemporary society and around the world;

- To build solidarity among peoples, especially those at risk of being deprived of rights, at the international, national and community levels;

- To engender moral responsibility in new generations to remember such "terrible truths" as the Holocaust, to "fight the evils" of genocide and identify possible strategies for prevention, ${ }^{48}$ "to promote the development of a more humane and informed citizenry"; ${ }^{49}$

- To protect world heritage in recognition of the fact that whenever a group of people ceases to exist the knowledge and richness of humanity is diminished and impoverished;

- To earn national redemption and promote reconciliation by writing critical reflexivity and regret into histories of non-responsiveness and collusion. ${ }^{50}$

Since 1998, signatory nations to the Stockholm Declaration of the International Holocaust Remembrance Alliance have committed themselves to educating their young people about the Holocaust and the ethical imperatives it dictates for today's world. The United Nations and UNESCO have each passed resolutions to promote Holocaust education ${ }^{51}$ and to support the development of curricula in cooperation with specialized organizations around the world such as the Yad Vashem Memorial and Research Center in Israel, the United States Holocaust Memorial Museum, the International Holocaust Remembrance Alliance, and Facing History and Ourselves. Such organizations engage with the subject in slightly different ways, providing resources, curricular guides, and trainings for educators and schools. International commemorations like Holocaust Memorial

46 F.A. Stone, “Teaching Genocide Awareness in Multicultural Education," Ethnic Studies Bulletin 6 (Mansfield: University of Connecticut, 1984).

47 Judy Barsalou and Victoria Baxter, The Urge to Remember: The Role of Memorials in Social Reconstruction and Transitional Justice (Washington, D.C.: USIP, 2007).

48 IHRA, Declaration of the Stockholm International Forum on the Holocaust (Berlin: IHRA, 2000), retrieved from https://www.holocaustremembrance.com, accessed 7 February 2018.

49 See Facing History and Ourselves Mission Statement (https://www.facinghistory.org/get-toknow-us/mission-statement), accessed 7 February 2018.

50 Salmons, "Teaching or Preaching?"

51 UN resolution 60/7 (1 November 2005), UNESCO resolution 34c/61 (2007). 
Day provide a locus around which participating schools organize awarenessraising and sensitizing activities.

As detailed by Carrier, Fuchs, and Messinger in their global study of 2015 on representations of the Holocaust in school curricula and textbooks, conceptualizations and practices of Holocaust education in state education systems vary considerably around the world. For example, in the UK, where the Holocaust has been a mandatory topic of instruction within the state secondary school history curriculum since 1991, classroom coverage ranges from 1-20 teaching hours per year and a range of textbooks and other resources from various publishers are available for elective classroom use. ${ }^{52}$ In stark contrast, in Israel, where the Holocaust has been a mandatory, examined subject in secondary schools since 1982, a single textbook whose coverage of the Holocaust has increased from 20 pages in the 1960 s to 450 pages in the 1990 s is used throughout the country. And since 2014, Holocaust education has been extended to all grades including kindergarten. ${ }^{53}$

\section{Six Lessons for Transitional Justice Education from Holocaust Education}

Drawing from the vast research literature on Holocaust education practice, highlighted here below are six lessons that may be of value to the design and implementation of transitional justice education. ${ }^{54}$ Guiding this selection was a focus on how to enable meaningful classroom learning within shifting social and political contexts through effective preparation and teaching. "Meaningful learning" in this context is intended to signify learning that is characterized by deep reflection and self-assessment which leads to the adoption or reaffirmation of values, choices, and actions that favor human connection, a critical under-

52 Alice Pettigrew, Paul Salmons, and Stuart Foster, Teaching About the Holocaust in English Secondary Schools: An Empirical Study of National Trends, Perspectives and Practice (London: University of London, 2009).

53 Lidar Gravé-Lazi, "New Holocaust Education Program in Israel to Start in Kindergarten," Jerusalem Post, 24 April 2014, 9-10. Retrieved from http://www.jpost.com/printarticle.as px?id=350335, accessed 7 February 2018.

54 More guidelines on "How to Teach the Holocaust" which may be of interest to teachers in transitional justice contexts may be found on the websites of the International Holocaust Remembrance Alliance (https://www.holocaustremembrance.com/node/319) and the Holocaust Memorial Museum (https://www.ushmm.org/educators/teaching-about-the-holo caust/general-teaching-guidelines). Another helpful briefing paper is the IHRA Education Working Group's "The Holocaust and other Genocides" (https://www.holocaustremem brance.com/sites/default/files/the_holocaust_and_other_genocides_0.pdf), all accessed 7 February 2018. 
standing of history, a sense of inclusive human solidarity and mutual responsibility, and an increased commitment to truth, justice, and non-violent action for social change.

\section{Meaningful coverage necessitates adequate curricular time and a clear} purpose

Teaching young people about histories of atrocity is a complex task. Not only is the history itself complex, but so too are the desired learning outcomes if they are to contribute meaningfully to transitional justice goals of promoting more just, inclusive, and peaceful societies. Teachers, students, communities, and authorities may have differing expectations of what classroom practice is intended to achieve, especially when terminologies like reconciliation, social reconstruction, and justice, which are frequently used in transitional justice contexts, are contested. It is difficult, if not impossible, to ensure educational value from learning about histories of atrocity if taught in a perfunctory manner, as a passing topic in one or two classroom lectures. Totten and Pederson remind us that back in 1979, historian and Holocaust surviver Henry Friedlander argued that educators must avoid "shallow and facile" coverage that can result from "lack of focus and attention to detail, such as accuracy of content and sound teaching methodologies." ${ }^{55}$ However, limited time and resources can lead teachers to make instructional choices on the basis of expediency rather than meaning. Adequate curricular space, teaching time, and clear learning objectives are needed for teachers and especially students to process what they are learning in productive ways that are aligned to desired cognitive, affective, and behavioral objectives.

\section{Lesson content and pedagogy are equally important}

Even with clear goals and definitions, teachers can struggle to represent the scope and significance of histories of atrocity in the classroom. Accurate and adequate coverage of the topic necessitates efforts to use a range of primary and secondary sources representing multiple perspectives, as well as active alertness on the part of the teacher to any selectiveness or bias in classroom representations of the

55 Henry Friedlander, "Toward a Methodology of Teaching about the Holocaust," The Teachers' College Record 80, no. 3 (1979): 519-542; Samuel Totten and Jon E. Pedersen, eds. Teaching and Studying Social Issues: Major Programs and Approaches (Charlotte, N.C.: Information Age Publishing, 2011); Barsalou and Baxter, The Urge to Remember, 3; Karen L. Riley and Samuel Totten, "Understanding Matters: Holocaust Curricula and the Social Studies Classroom," Theory \& Research in Social Education 30, no. 4 (2002): 541-562. 
events in question. Adapting materials and learning activities to the developmental capacities of students will also help make lessons more meaningful. However, collecting, synthesizing, and deriving pedagogical value from documentary and supplementary materials can be a major challenge for teachers when records of the events surrounding the country's human rights abuses are lacking, inaccessible or, indeed, overly abundant. Materials are only a startingpoint, however, and do not guarantee effective teaching about sensitive and contested histories. The selection of appropriate pedagogical strategies is equally important.

Totten ${ }^{56}$ identifies a number of common pedagogical pitfalls in the field of Holocaust education that may equally apply to transitional justice education. These include:

- Focusing on the factual issues of "who," "what," "where," and "when" of human rights abuses, to the neglect of ethical questions around "why" and "how" such actions occurred;

- Assaulting students with a series of horrific images that may simply overwhelm them or depersonalize the victims;

- Conversely, denying the grim reality of atrocities by minimizing the fact that perpetrators committed ghastly crimes;

- Failing to provide an accurate representation of not only perpetrators and victims of crimes, but also of collaborators, bystanders, and rescuers;

- Failing to transcend selective outgroup-centered accounts of atrocities and bringing together opposing collective narratives of the violent past;

- Failing to locate atrocities within the historical context of inter-related political, social, and economic factors;

- Skewing history by minimizing or overstating various aspects of the atrocities;

- Providing simple answers to complex questions and situations;

- Allowing students to believe that history "happens" rather than being the result of a series of choices.

Teachers must exercise sensitivity to the developmental maturity of students and the corresponding appropriateness of learning activities. This includes vigilance to the "dosing" of student exposure to atrocities and critical reflection by the teacher on the benefits and limits of such exposure. Disbelief, disgust, shame, and outrage are among the range of normal emotional responses to human atrocity, and students may not be able to avoid experiencing them. But the pedagogical value of such emotions arguably depends upon the extent to which

56 Samuel Totten, ed., Teaching about Genocide: Issues, Approaches, and Resources (Greenwich, CT: Information Age Publishing, 2006). 
these emotions are then channelled to produce among students an increased commitment to truth, to human connection, to redress, and to prevention of human rights abuses. Training is essential to preparing teachers to identify relevant documentary resources, to use effective pedagogical strategies for critical and coherent exploration with students, and to support teachers in assessing (and recuperating from) their own engagement with these sensitive materials and discussions.

Classroom methods that have been used successfully in Holocaust education include the study of first-person non-fictional narratives such as oral histories and court testimonies. Inquiry into moral dilemmas, teacher and student reflective journaling, school visits by survivors and their descendants, educational visits to sites of memorialization such as former concentration camps or killing fields, and use of online and multimedia resources are also recommended. ${ }^{57}$ Helping students to process the social and political complexities of mass human violence creates important opportunities for multi-perspectival learning through active questioning and discussion. Comparative studies in genocide, however, are regarded with caution, as they risk relativizing or ranking the suffering of atrocities in different contexts. ${ }^{58}$ Controversial methods such as shock tactics and simulations are strongly discouraged, as Salmons and Airton have pointed out. ${ }^{59}$

Totten argues that the best pedagogical practices in this difficult subject area are student-centered:

[Activities] in which the students are not passive but rather actively engaged ... that, in the best sense of the word, "complicates" the students' thinking, engages them in critical and creative thought, and involves in-depth versus superficial coverage of information. It should also involve students in reading and examining primary sources ... in conjunction with first person accounts by survivors and other witnesses ... [in order to] help students grapple with the choices, decisions, actions and inaction made by perpetrators, collaborators, bystanders, victims, and others. ${ }^{60}$

Student-based research is also advocated by Cole as a means for exploring "history from below." Tasks that encourage critical and ethical self-reflection

57 See, respectively, Airton, Literature Review on Genocide Pedagogies; Salmons, "Teaching or Preaching?"; David H. Lindquist, "A Necessary Holocaust Pedagogy: Teaching the Teachers," Issues in Teacher Education 16, no. 1 (2007): 21-36; UK Foreign and Commonwealth Office. Report on Holocaust Education in the United Kingdom (London: FCO, 2010); IHRA, Using Social Media in Holocaust Education (Berlin: IHRA, 2015).

58 ITF, 2010 Education Working Group Paper on the Holocaust and Other Genocides.

59 Airton, Literature Review on Genocide Pedagogies; Salmons, "Teaching or Preaching?".

60 Totten, ed., Teaching about Genocide, 215-216. See also Samuel Totten and Stephen Feinberg, Teaching and Studying the Holocaust (Charlotte, NC: IAP, 2009).

61 Cole, "Transitional Justice and the Reform of History Education." 
enable young people to move beyond facts and figures to recognize the psychological and structural supports that enabled mass crimes, and to contrast criminal and bystander behaviour with the actions and legacies of defenders of human rights and human dignity. Student-centered learning better enables young people to become aware of their power to choose how they participate in history, and to experience their own agency as social, moral, and political actors:

By integrating the study of history and literature with ethical decision-making and innovative teaching strategies, [the] program enables secondary school teachers to promote students' historical understanding, critical thinking, and social-emotional learning, and facilitate transformative dialogue in their classrooms. As students explore the complexities of history, they reflect on the choices they confront today and consider how they can make a difference. ${ }^{62}$

While it is natural that educators may use a combination of instructional methods, Lindquist warns against teacher-training programs focusing wholly on methods to the exclusion of helping teachers understand and frame the events in question within a clearly defined historical context. Too often, he argues, "teachers who attend such programs return to their classrooms with a potpourri of activities that are neither coherent with each other nor contextually based from the historical perspective." ${ }^{63}$

\section{Resistance to policy integration and classroom instruction is common}

Despite the normative arguments and policy agreements in favor of addressing histories of human atrocity through education, research on Holocaust education reveals that there are many reasons why countries and schools fail to do so. Contestation, lack of support and active opposition at the political, social, or cultural level can occur due to one or several of the following reasons:

- Taboo and/or trauma: The subject matter is perceived as uncomfortable, shameful, and/or potentially (re)traumatizing for teachers and especially children and young people;

- Historical complexity: The complexity of the historical events, their roots and the array of roles and experiences they contain, can be perceived as too difficult to represent justly;

62 See the Facing History and Ourselves website: https://www.facinghistory.org/for-educators/ educator-resources/our-pedagogy, accessed 7 February 2018.

63 Lindquist, "A Necessary Holocaust Pedagogy." 
- Pedagogical complexity: Concern that mere exposure to horror does not ensure that students become informed, morally courageous decision-makers and actors ${ }^{64}$

- Literature dilemmas: Apart from the Holocaust, there is a dearth of multiperspectival pedagogic literature on other histories of atrocity and genocide. Most literature is either anecdotal, technical/legalistic, or political i.e. produced by interested parties to the conflict; ${ }^{65}$

- Political controversy: There is a desire to avoid agitating surviving participants, accomplices, victims, and their respective descendants, and to avoid facing unpleasant aspects of one's own national history (e.g. collaboration with Nazis, Britain's policies towards Jewish refugees during the Holocaust, and events in Nazi-occupied Channel Islands). There can also be fears of eliciting criticism against present state policies (e.g. toward domestic minorities, refugee quotas, international military interventions or lack thereof, etc.) and other unresolved issues (e.g. looted items in state collections), or of being associated with disfavored contemporary political actors $;{ }^{66}$

- Political threat: The subject matter is perceived as a direct threat to the continued power of domestic military and political apparatuses and is therefore suppressed; ${ }^{67}$

- Religious controversy: There is a desire to avoid covering histories of institutionally-sanctioned religious prejudice (e.g. anti-Semitism) which have contributed decisively to the unfolding of genocide in order to avoid unpleasant encounters with one's own religious convictions and with religiously affiliated students and teachers from one's community; ${ }^{68}$

- Personal fears: Teachers who have witnessed human atrocities may be unwilling to teach the subject even if mandated because of fear of confronting their own identities, legacies, and biases. ${ }^{69}$

64 Nicholas Kinloch, "Learning about the Holocaust: Moral or Historical Question?," Teaching History 93 (1998): 44.

65 Airton, Literature Review on Genocide Pedagogies.

66 See UK Foreign and Commonwealth Office, Report on Holocaust Education in the United Kingdom and Simone Schweber, "Holocaust Fatigue in Teaching Today," Social Education 7, no. 1 (2006): 44-50.

67 Antoon de Baets, "The Dark Side of Historical Writing: Reflections on the Censorship of History Worldwide (1945-2012)," in Riparare, risarcire, ricordare: un dialogo tra storici e giuristi, vol. 1, edited by Giorgio Resta and Vincenzo Zeno-Zencovich (Napoli: Editoriale Scientifica, 2012), 343-370; Antoon de Baets, "Post-Conflict History Education Moratoria: A Balance," World Studies in Education 16, no. 1 (2015): 5-30.

68 Schweber, "Holocaust Fatigue."

69 Gail Weldon, A Comparative Study of the Construction of Memory and Identity in the Curriculum in Societies Emerging from Conflict: Rwanda and South Africa. Doctoral dissertation, University of Pretoria, 2009. 
These various concerns necessitate that educators aiming to teach the violent past in the classroom receive ample support for personal reflection and preparation. Educators will also need professional support to reflect carefully upon the selection of material and monitor students' responses to it. Finally, educational leaders and administrators, as well as the community of parents and guardians, should be informed of the nature and purpose of transitional justice education and be offered opportunities to participate in outreach activities. Prerequisite to all of this is the need for "being clear and upfront about the goals the project is trying to achieve."70

\section{Educators must remain vigilant to the negative instrumentalization of memory}

Teaching about one's own history of atrocity is different in important ways from teaching about the histories of others. A risk in transitional justice education is that social groups, institutions, teachers, and families hijack and counteract the transitional justice agenda. While classroom discussion of mass human rights abuses can support the formation of new national and community identities, narratives of remembrance which fail to connect students to a sense of shared humanity, moral inclusivity, and universal responsibility can fuel conflict dynamics by reinforcing "chosen traumas." 71

In British and American schools, teachers and students tend to approach the subject of the Holocaust as something that happened in another time and place, (mostly) to other people, but with important lessons that may be gleaned for the here and now, whereas in Israeli and Palestinian schools, Holocaust education is characterized by strong "us versus them" narratives and competing claims to victimhood. ${ }^{72}$ The same is evident in other societies, like Bosnia and Herzegovina, where proximal groups have been divided by violent atrocities. Classroom narratives about the recent past focus on "our" people, our history, our struggle, our sacrifices, our purposes as a nation, our past, present, and future. The underlying messages received by students are that "we" are the victims of "their"

70 Barsalou and Baxter, The Urge to Remember, 3.

71 Vamik D. Volkan, “On Chosen Trauma," Mind and Human Interaction, 3, no. 1 (1991): 13.

72 Samira Alayan, "The Holocaust in Palestinian Textbooks: Differences and Similarities in Israel and Palestine," Comparative Education Review 60, no. 1 (2016); Ilan Gur-Ze'ev, “The Production of Self and the Destruction of the Other's Memory and Identity in Israeli/Palestinian Education on the Holocaust/Nakbah," Studies in Philosophy and Education 20 (2001): 255-266; Ayana Nir, “The Crisis in Israel's Holocaust Education," Tikkun Daily, April 23, 2014. Retrieved from http://www.tikkun.org/tikkundaily/2014/04/23/the-crisis-in-israelsholocaust-education/. 
heinous acts, their evils, their guilt. "We" are duty-bound to inform each generation of this victimhood in order to honor our past losses and heroes, to remain vigilant to threats, to defend ourselves against possible future attacks, and we are justified in doing so. Such "limiting constructions of the [collective] self" lead to an "institutionalized unwillingness ... to acknowledge each other's suffering" manifested in discursive silences and denials which are generally intolerant to both external and internal critique. ${ }^{73}$ Memories of atrocity are thereby instrumentalized to legitimize the goals of nation-building and to resist peacebuilding and reconciliation. ${ }^{74}$

The Israeli-Palestinian case demonstrates that while international commitments to Holocaust education are focused on sensitizing students to others' suffering under genocidal persecution with the objective to activate younger generations as defenders of human rights for all, the proximity of that history and its intersection with contemporary Israeli-Palestinian politics undermines such a transformative educational agenda. Similar risks may be encountered in transitional justice contexts.

Teaching and learning about historical atrocities can diminish hope and agency

Another insight to be gleaned from Holocaust education research is that learning about histories of atrocity can lead to pessimism and feelings of helplessness among young people. Students may be daunted by the scale of injustice in the world and their limited capacity as individuals to effect a significant change. The challenge, as Cole sees it, is "balancing a frank critique of the past with a narrative that is positive enough to engage students. ${ }^{37}$ Especially in transitional societies where the legacies of conflict and non-democratic modes of governance present obstacles to social and economic reconstruction, peace, justice, and reconciliation, teachers risk nurturing despair and passivity in young people if classroom instruction focuses on perpetrators and victims, and the exclusion of heroes; and if milestones in the progress of $\mathrm{TJ}$ measures and constructive roles for young people are not brought to their attention. "Students need a useable past ... in which they can find values and projects to take as their legacies ... 'something

73 Gur-Ze'ev, “The Production of Self," 255. Genocide scholar Gregory Stanton identifies denial as the last of eight stages of genocide. Denial is a by-product of impunity and can fuel future instances of mass violence. Gregory H. Stanton, "The Eight Stages of Genocide," Yale Genocide Studies Series, GS01 (1998), 6-7.

74 Barsalou and Baxter, The Urge to Remember.

75 Cole, "Transitional Justice and the Reform of History Education," 128. 
perfectible' [to be] carried forward." "76 In order to address this concern, Shawn and Lindquist both argue for comprehensive subject preparation, including personal preparation of teachers in regard to their own feelings towards the past, the future, and their own sense of agency. ${ }^{77}$ Teachers need to have a plan for how they will channel students' understanding of the past in ways that equip, inspire, and empower them to build a better future. A conscious focus on the development of student agency to initiate and/or participate in activities related to transitional justice can strengthen hope in and commitment to social healing, community rebuilding and positive peace.

\section{Curricula and pedagogy have to evolve as meanings and classroom attitudes shift over time}

Research on Holocaust education in the UK and USA shows that students' attitudes towards histories of atrocity change from generation to generation. Schweber has documented shifts from "Holocaust sacralization" to "Holocaust fatigue" to "Holocaust trivialization," and increasingly to "Holocaust denial" (especially in the form of virulent anti-Semitism on the internet) ${ }^{78}$ Whereas the perceived sanctity of the Holocaust in the early years of curricular inclusion risked standing in the way of history being critically investigated, questioned, and understood, subsequent perceptions of "over-exposure" - the notion that "this particular event is being taught to death" due to perennial curricular inclusion - ultimately produced topical fatigue and counter-productive cultural and commercial trivialisation that diminished students' abilities to understand the Holocaust's significance. ${ }^{79}$

Barsalou and Baxter also found that "the meaning of memorials often shifts over time and depends on the life experiences of the viewer ... It may [therefore] be necessary for memorial sites to evolve to accommodate social transformations." ${ }^{80}$ Indeed, as generations shift, teachers are advised to be sensitive to changes in the political climate and in classroom demographics. Different vantage points and sensitivities may need to be managed when discussing

76 Robert K. Fullinwider, “Patriotic Education,” in Robert K. Fullinwider, ed., Public Education in a Multicultural Society: Policy, Theory, Critique (Cambridge: Cambridge University Press, 1996), 222.

77 Karen Shawn, "Current Issues in Holocaust Education," Dimensions: A Journal of Holocaust Studies 9, no. 2 (1995): 16 and Lindquist, "A Necessary Holocaust Pedagogy."

78 Schweber, "Holocaust Fatigue."

79 UK Foreign and Commonwealth Office, Report on Holocaust Education in the United Kingdom (2010).

80 Barsalou and Baxter, The Urge to Remember, 17. 
complex histories. ${ }^{81}$ Particularly as young people are increasingly exposed to hate speech, genocide denial, and other forms of extremism via social media, teachers may need special preparation to guide students constructively through controversial exchanges. ${ }^{82}$

\section{Conclusions}

Transitional justice education aims to offer younger generations an opportunity to engage critically with their country's recent violent past, to make sense of what they have witnessed and heard about, and to understand how "their own experiences [form] part of a larger and more complex phenomenon that ... left enduring legacies in the present political and social space." ${ }^{83}$ If planned and practised effectively, transitional justice education can enable "offspring of both victims and perpetrators [to] discuss these issues safely, critically and without fear," thereby "harness[ing] memory to learn lessons from the past in an effort to avoid repeating it in future." 84

As this chapter indicates, the opportunities and challenges in this regard are numerous. Ideally, proximal groups who have been divided by violent atrocities and have begun to engage in transitional justice processes will adopt a common, albeit complex narrative that centers on the rights of all human beings to dignity, safety, and whole development, recognizing that any violation of these rights is a threat to all. Ideally also, authorities and the population-at-large will recognize that past injustices can only be averted in future through the responsibilisation ${ }^{85}$ of all individuals, groups, and institutions. Learning for this purpose, however, does "not occur spontaneously." Holocaust education practice offers invaluable lessons for designing and teaching about and for transitional justice. In this chapter, I examined only a handful of those insights, including the need for "meaningful" learning ob-

81 Z. Bekerman and M. Zembylas, Teaching Contested Narratives: Identity, Memory and Reconciliation in Peace Education and Beyond (Cambridge: Cambridge University Press, 2011).

82 See Lindquist, "A Necessary Holocaust Pedagogy"; and Christopher Wolf, "Holocaust Denial and Freedom of Speech in the Internet Era," in Berlin Conference on Holocaust Denial and Freedom of Speech in the Internet Era (Berlin, 2011). Retrieved from http://www.adl.org/ combating-hate/cyber-safety/c/holocaust-denial-and-freedom.html.

83 Ramírez-Barat and Duthie, Education and Transitional Justice, 15.

84 Barsalou and Baxter, The Urge to Remember, 4.

85 Responsibilization implies not only the awareness and acceptance of one's moral and civil responsibility to act, but also the development of a corresponding moral courage, maturity, and capacity necessary to fulfil that responsibility.

86 Ana María Rodino, "Pedagogical Guidelines for Teaching about the Recent Past and Citizenship Education in Processes of Democratic Transition," paper given at the Georg Arnhold Summer School on Transitional Justice and Education (2015). 
jectives and the importance of teacher preparation. I highlighted some of the pedagogical pitfalls that are best avoided, drew attention to political and ethical challenges that may have to be negotiated in the classroom, and observed that generational shifts may demand the revision of educational strategies over time. Further research may explore the application of these insights within and across unique transitional justice contexts.

\section{Bibliography}

Abdi, Ali A. and Lynette Shultz, eds. Educating for Human Rights and Global Citizenship. Albany: SUNY Press, 2009.

Airton, Liz. Literature Review on Genocide Pedagogies and Curricula: 1980 to Present. Montréal: Life Stories in Education Working Group, 2009.

Alayan, Samira. "The Holocaust in Palestinian Textbooks: Differences and Similarities in Israel and Palestine." Comparative Education Review 60, no. 1 (2016): 80-104.

Andreopoulos, George J. and Richard Pierre Claude, eds. Human Rights Education for the Twenty-First Century. Pennsylvania Studies in Human Rights. Philadelphia: University of Pennsylvania Press, 1997.

Bajaj, Monisha. Encyclopedia of Peace Education. Charlotte, N.C.: Information Age Publishing, 2008.

Barsalou, Judy. Trauma and Transitional Justice in Divided Societies. Special Report. Washington, D.C.: USIP, 2005.

Barsalou, Judy and Victoria Baxter. The Urge to Remember: The Role of Memorials in Social Reconstruction and Transitional Justice. Washington, D.C.: USIP, 2007.

Bekerman, Zoi and Michalinos Zembylas. Teaching Contested Narratives: Identity, Memory and Reconciliation in Peace Education and Beyond. Cambridge: Cambridge University Press, 2011.

Bilić, Bojan. “A Concept that is Everything and Nothing: Why not to Study (Post-) Yugoslav Anti-War and Pacifist Contention from a Civil Society Perspective." Sociologija LIII, no. 3 (2011): 297-322.

Bromley, Patricia and Susan Garnett Russell. "The Holocaust as History and Human Rights: A Cross-national Analysis of Holocaust Education in Social Science Textbooks, 1970-2008." Prospects 1 (2010): 153-173.

Bush, Kenneth D. and Diana Saltarelli. The Two Faces of Education in Ethnic Conflict: Towards a Peacebuilding Education for Children. New York: UNICEF/Innocenti, 2000.

Carrier, Peter, Eckhardt Fuchs and Torben Messinger. The International Status of Education about the Holocaust: A Global Mapping of Textbooks and Curricula. New York: UNESCO/Georg Eckert Institute for International Textbook Research, 2015.

Clark, Janine N. "The Limits of Retributive Justice: Findings of an Empirical Study in Bosnia and Hercegovina." Journal of International Criminal Justice 7, no. 3 (2009): 463-487.

Cole, Elizabeth. "Transitional Justice and the Reform of History Education.” International Journal of Transitional Justice 1, no. 1 (2007): 115-137. 
Daly, Erin. Transformative Justice: Charting a Path to Reconciliation. International Legal Perspectives 12, no. 1-2 (2002): 73-183.

Danesh, Hossain B. "Creating a Culture of Healing in Multiethnic Communities: An Integrative Approach to Prevention and Amelioration of Violence-induced Conditions." Journal of Community Psychology 36, no. 6 (2008): 814-832. doi:10.1002/jcop.

de Baets, Antoon. "The Dark Side of Historical Writing: Reflections on the Censorship of History Worldwide (1945-2012)." In Riparare, risarcire, ricordare: un dialogo tra storici e giuristi, edited by Giorgio Resta and Vincenzo Zeno-Zencovich. Vol. 1, 343-370. Napoli: Editoriale Scientifica, 2012.

de Baets, Antoon. "Post-Conflict History Education Moratoria: A Balance." World Studies in Education 16, no. 1 (2015): 5-30.

Fischer, Martina and Ljubinka Petrović-Ziemer. Dealing with the Past and Peacebuilding in the Western Balkans. Osnabrück: Deutsche Stiftung Friedensforschung, 2015.

Fletcher, Laurel E. and Harvey M. Weinstein. "A World unto Itself? The Application of International Justice in the former Yugoslavia." In My Neighbor, My Enemy: Justice and Community in the Aftermath of Mass Atrocity, edited by Eric Stover and Harvey M. Weinstein. Cambridge: Cambridge University Press, 2004.

Fountain, Susan. Peace Education in UNICEF. New York: UNICEF, 1999. Retrieved from http://www.unicef.org/education/files/PeaceEducation.pdf. Accessed 7 February 2018.

Fraser, Nancy. "Social Justice in the Age of Identity Politics: Redistribution, Recognition and Participation." In Redistribution or Recognition? A Political-Philosophical Exchange, edited by Nancy Fraser and Axel Honneth. 7-109. London: Verso, 2003.

Friedlander, Henry. "Toward a Methodology of Teaching about the Holocaust." The Teachers College Record 80, no. 3 (1979): 519-542.

Fullinwider, Robert K. "Patriotic Education." In Public Education in a Multicultural Society: Policy, Theory, Critique, edited by Robert K. Fullinwider. Cambridge: Cambridge University Press, 1996.

Gravé-Lazi, Lidar. "New Holocaust Education Program in Israel to Start in Kindergarten." Jerusalem Post, 24 April 2014.9-10. Retrieved from http://www.jpost.com/printarti cle.aspx?id=350335, accessed 7 February 2018.

Gray, David C. "An Excuse-Centered Approach to Transitional Justice." Fordham Law Review 74, no. 5 (2006): 2621-2693.

Guinn, David E. "Human Rights Education: The Third Leg of Post-Conflict/Transitional Justice." Human Rights and Human Welfare: Working Papers, no. 42 (2005).

Gur-Ze'ev, Ilan. "The Production of Self and the Destruction of the Other's Memory and Identity in Israeli/Palestinian Education on the Holocaust/Nakbah." Studies in Philosophy and Education 20 (2001): 255-266.

Harris, Ian M. and Mary Lee Morrison. Peace Education. Third edition. Jefferson, NC: McFarland, 2012.

Hayden, Robert M. "What's reconciliation got to do with it? The International Criminal Tribunal for the Former Yugoslavia (ICTY) as Antiwar Profiteer." Journal of Intervention and Statebuilding 5, no. 3 (2011): 313-330.

Hayner, Priscilla B. Unspeakable Truths: Facing the Challenge of Truth Commissions. Second edition. New York: Routledge, 2011 [2001, 2002].

Hinton, Alexander Laban, ed. Transitional Justice: Global Mechanisms and Local Realities After Genocide and Mass Violence. New Brunswick, N.J.: Rutgers University Press, 2010. 
Holland, Tracey. "Human Rights Education in Peace-Building: A Look at Where the Practice has Come From, and Where it Needs to Head." Human Rights \& Human Welfare. Working Paper 62. 2010.

IHRA. Declaration of the Stockholm International Forum on the Holocaust. Berlin: IHRA, 2000.

IHRA. Using Social Media in Holocaust Education. Berlin: IHRA, 2015.

INEE. INEE Guidance Note on Conflict Sensitive Education. Geneva: Inter-Agency Network for Education in Emergencies, 2013.

ITF. 2010 Education Working Group Paper on the Holocaust and Other Genocides.

Johnson, David W. and Roger T. Johnson. "Essential Components of Peace Education." Theory into Practice 44, no. 4 (2005): 280-292.

Kinloch, Nicolas. "Learning about the Holocaust: Moral or Historical Question?” Teaching History 93 (1998): 44-46.

Kostić, Roland. "Transitional Justice and Reconciliation in Bosnia-Herzegovina: Whose Memories, Whose Justice?" Sociologija 54, no. 4 (2012): 649-666.

Laplante, Lisa J. “Transitional Justice and Peace Building: Diagnosing and Addressing the Socioeconomic Roots of Violence through a Human Rights Framework." International Journal of Transitional Justice 2, no. 3 (2008): 331-355.

Leebaw, Bronwyn A. “The Irreconcilable Goals of Transitional Justice." Human Rights Quarterly 30, no. 1 (2008): 95-118.

Lindquist, David H. “A Necessary Holocaust Pedagogy: Teaching the Teachers." Issues in Teacher Education 16, no. 1 (2007): 21-36.

McGlynn, Claire, Michalinos Zembylas, Zvi Bekerman, and Tony Gallagher. Peace Education in Conflict and Post-Conflict Societies.New York: Palgrave Macmillan, 2009.

Meseth, Wolfgang and Matthias Proske. "Mind the Gap: Holocaust Education in Germany, between Pedagogical Intentions and Classroom Interactions." Prospects 40 (2010): 201-222.

Murphy, Karen. Educational Reform through a Transitional Justice Lens: The Ambivalent Transitions of Bosnia and Northern Ireland. New York: International Center for Transitional Justice, 2015.

Niens, Ulrike and Jacqueline Reilly. "Education for Global Citizenship in a Divided Society? Young People's Views and Experiences.” Comparative Education 48, no. 1 (2012): 103-118.

Nir, Ayana. “The Crisis in Israel's Holocaust Education.” Tikkun Daily, 23 April, 2004. Retrieved from http://www.tikkun.org/tikkundaily/2014/04/23/the-crisis-in-israelsholocaust-education/.

Novelli, Mario, Mieke T. A. Lopes Cardozo, and Alan Smith. A Theoretical Framework for Analysing the Contribution of Education to Sustainable Peacebuilding: 4Rs in ConflictAffected Contexts. University of Amsterdam, UNICEF Consortium on Education and Peacebuilding, 2015.

Opotow, Susan. "Psychology of Impunity and Injustice: Implications for Social Reconciliation." In Post-Conflict Justice, edited by M. C. Bassiouni, 201-216. Ardsley, NY: Transnational Press, 2002.

Page, James S. "The United Nations and Peace Education.” In Encyclopedia of Peace Education. Charlotte, N.C.: Information Age Publishing, 2008. 
Paulson, Julia. (Re)Creating Education in Postconflict Contexts: Transitional Justice, Education, and Human Development. ICTJ report. New York: International Center for Transitional Justice, 2009.

Pettigrew, Alice, Paul Salmons, and Stuart Foster. Teaching About the Holocaust in English Secondary Schools: An Empirical Study of National Trends, Perspectives and Practice. London: University of London, 2009.

Ramírez-Barat, Clara. Making an Impact: Guidelines on Designing and Implementing Outreach Programs for Transitional Justice. New York: International Center for Transitional Justice, 2011.

Ramírez-Barat, Clara. Engaging Children and Youth in Transitional Justice Processes: Guidance for Outreach Programs. Report. New York: International Center for Transitional Justice, 2012.

Ramírez-Barat, Clara and Roger Duthie. Education and Transitional Justice: Opportunities and Challenges for Peacebuilding. New York: International Center for Transitional Justice, 2015.

Reardon, Betty. Comprehensive Peace Education: Educating for Global Responsibility. New York: Teachers College Press, 1988.

Rendel, Margherita. "Some Problems in Teaching Human Rights." In Human Rights, Education, and Global Responsibilities, edited by James Lynch, Celia Modgil, and Sohan Modgil. Vol. 4, 151-162. London: The Falmer Press, 1992.

Riley, Karen. L. and Samuel Totten. "Understanding Matters: Holocaust Curricula and the Social Studies Classroom." Theory \& Research in Social Education 30, no. 4 (2002): 541-562.

Ross, Fiona C. "An Acknowledged Failure: Women, Voice, Violence, and the South African Truth and Reconciliation Commission." In Localizing Transitional Justice: Interventions and Priorities after Mass Violence, edited by Rosalind Shaw and Lars Waldorf, 69-91. Stanford University Press, 2010.

Salmons, Paul. "Teaching or Preaching? The Holocaust and Intercultural Education in the UK." Intercultural Education 14, no. 3 (2003): 139-149.

Salomon, Gavriel and Baruch Nevo. Peace Education: The Concept, Principles, and Practices Around the World. London: Psychology Press, 2005.

Schweber, Simone. "Holocaust Fatigue in Teaching Today." Social Education 7, no. 1 (2006): 44-50.

Shawn, Karen. “Current Issues in Holocaust Education.” Dimensions: A Journal of Holocaust Studies 9, no. 2 (1995): 15-18.

Sriram, Chandra Lekha. "Justice as Peace? Liberal Peacebuilding and Strategies of Transitional Justice." In The Liberal Peace and Post-War Reconstruction-Myth or Reality, edited by Roger MacGinty and Oliver Richmond. New York and Oxon: Routledge, 2009.

Stanton, Gregory H. “The Eight Stages of Genocide.” Yale Genocide Studies Series, GS01 (1998). Retrieved from http://www.keene.edu/cchs/pdf/p_Genocide_8stages.pdf., accessed 7 February 2018.

Stone, Frank A. "Teaching Genocide Awareness in Multicultural Education." Ethnic Studies Bulletin 6 (1984).

Stover, Eric and Harvey M. Weinstein, eds. My Neighbour, My Enemy: Justice and Community in the Aftermath of Mass Atrocity (Cambridge: Cambridge University Press, 2004). 
Subotić, Jelena. Hijacked Justice: Dealing with the Past in the Balkans. Ithaca/New York: Cornell University Press, 2009.

Tibbitts, Felisa and William R. Fernekes. "Human Rights Education." In Teaching and Studying Social Issues: Major Programs and Approaches, edited by Samuel Totten and Jon E. Pedersen, 87-118. Charlotte, NC: Information Age Publishing, 2011.

Totten, Samuel. Teaching about Genocide: Issues, Approaches, and Resources. Greenwich, CT: Information Age Publishing, 2006.

Totten, Samuel. "Holocaust Education." In Educating about Social Issues in the 20th and 21st Centuries: A Critical Annotated Bibliography, edited by Samuel Totten and Jon E. Pedersen, 223-250. IAP, 2012.

Totten, Samuel and Stephen Feinberg. Teaching and Studying the Holocaust. IAP, 2009. Totten, Samuel and Jon E. Pedersen, eds. Teaching and Studying Social Issues: Major Programs and Approaches. Charlotte, N.C.: Information Age Publishing, 2011.

UK Foreign and Commonwealth Office. Report on Holocaust Education in the United Kingdom. London: FCO, 2010.

UN General Assembly. Transforming our World: The 2030 Agenda for Sustainable Development. doi:10.1007/s13398-014-0173-7.2. New York: UN, 2015.

UNESCO. The Hidden Crisis: Armed Conflict and Education. EFA Global Monitoring Report. doi: ISBN 978-92-3-104191-4. New York: UNESCO, 2011.

UNICEF. Case Study Guidance and Template: Peacebuilding Education and Advocacy (PBEA) Programme in Conflict-Affected Contexts. New York: UNICEF, 2012.

UNICEF Education Section. Proposal on Peacebuilding and Education presented to the Ministry of Foreign Affairs Government of the Netherlands. New York: UNICEF, 2011. van der Merwe, Hugo, Victoria Baxter, and Audrey R. Chapman, eds. Assessing the Impact of Transitional Justice: Challenges for Empirical Research. Washington, DC: US Institute of Peace Press, 2009.

Volkan, Vamik D. "On Chosen Trauma." Mind and Human Interaction 3, no. 1 (1991). Weldon, Gail. A Comparative Study of the Construction of Memory and Identity in the Curriculum in Societies Emerging from Conflict: Rwanda and South Africa. Doctoral dissertation, University of Pretoria, 2009.

Wolf, Christopher. "Holocaust Denial and Freedom of Speech in the Internet Era." In Berlin Conference on Holocaust Denial and Freedom of Speech in the Internet Era. Berlin: ADL, 2011. Retrieved from http://www.adl.org/combating-hate/cyber-safety/c/holocaustdenial-and-freedom.html.

Wulf, Christoph., ed. Handbook on Peace Education. Frankfurt: International Peace Research Association, 1974. 
Open-Access-Publikation im Sinne der CC-Lizenz BY 4.0

(c) 2018, V\&R unipress $\mathrm{GmbH}$, Göttingen 


\section{"People's Power" in the Age of Human Rights: Victims' Contributions to Education in Post-Apartheid South Africa}

Since South Africa's first democratic elections in 1994, the country's transitional justice process has been criticized for inadequately addressing the race-based historical and structural injustices entrenched under colonialism and apartheid, which have left the country with one of the highest levels of inequality in the world today. ${ }^{1}$ This chapter looks at the links between the transition and ongoing socioeconomic exclusion from the perspective of education, arguing that postapartheid education reforms illustrate how the institutional reforms that have accompanied the global rise and dominant practice of human rights and transitional justice in the post-Cold War period do not fulfil their potential for enabling social transformation. Concentrating on the transitional preoccupation with mainstreaming human rights culture, the chapter contrasts human rights education as expressed in South Africa's post-1994 formal curriculum and as reflected in the informal educational activities of the national apartheid victims' organization, Khulumani Support Group.

Khulumani is a membership-based organization established in 1995 to inform victims and provide assistance when engaging with the South African Truth and Reconciliation Commission (TRC). With a national membership of more than 100,000 victims and branches in every province of South Africa, the organization continues to this day to advocate for accountability, truth recovery, and reparations for past abuses, while also fostering self-empowerment, solidarity, and healing among victims and their families and communities. While education is not stated as a primary aim of the organization, Khulumani engages

1 See, e.g., Colin Bundy, "The Beast of the Past: History and the TRC," in After the TRC: Reflections on Truth and Reconciliation in South Africa, edited by Wilmot James and Linda van de Vijver (Athens: Ohio University Press, 2001). The election of Nelson Mandela to the presidency in 1994 ended more than four decades of apartheid, a system of segregation that institutionalized the racial hierarchies initiated under colonialism. Using the ideology of white supremacism, the apartheid government classified the population according to race - native/ Bantu/black, coloured, Indian/Asian, or European/white - and ensured the political, economic, and social subjugation of the majority, with lasting effects. 
in a range of informal educational activities that have received little scholarly attention. ${ }^{2}$ This chapter suggests that Khulumani's educational activities draw on the example of apartheid-era struggles for alternative and inclusive education as articulated in the concept of "People's Education." It argues that these activities go further than the post-apartheid education system in supporting active citizenship and social transformation. The activities indicate that victims' groups like Khulumani are in a position to fill a gap in national transitional justice processes by highlighting and addressing structural injustices of the past and their legacies in the present.

The chapter begins with a brief history of education reform in South Africa in relation to human rights and transitional justice in the 1990s in the context of the TRC, including Khulumani's engagement with formal education in this period. It then discusses the influence of the concept of a political, community-led, and empowerment-based People's Education as an alternative to apartheid education on the development of human rights education in the post-apartheid curriculum, as well as the failure of human rights education in South Africa to live up to its transformative promise to date. It discusses Khulumani's educational activities with the public broadly and with youth specifically beginning in the 2000s, showing how they come closer to fulfilling the goals of People's Education by dealing with historical and structural injustices in response to the "unfinished business" of the TRC after its closing. The chapter concludes with reflections on the potential role of victims' groups in education reform, with a view to bringing a more transformative agenda into transitional justice efforts to deal with past abuses.

2 For more information on Khulumani, see http://www.khulumani.net. As the national victims' movement in South Africa, which is considered a global "model" for transitional justice, Khulumani and its activism over the years have inspired an extensive base of scholarly literature, focusing on victims' experiences and perceptions of the truth commission (e.g., Richard Wilson, The Politics of Truth and Reconciliation in South Africa: Legitimizing the PostApartheid State, Cambridge: Cambridge University Press, 2001), experiences and discourses around psychological trauma (e.g., Christopher J. Colvin, "Shifting Geographies of Suffering and Recovery: Traumatic Storytelling after Apartheid," in Borders and Healers: Brokering Therapeutic Resources in Southeast Africa, edited by Tracy J. Luedke and Harry G. West (Bloomington: Indiana University Press, 2006), and contributions to transitional justice practice, including a groundbreaking lawsuit seeking corporate accountability for apartheid collusion using the United States Alien Tort Statute (Rita Kesselring, Bodies of Truth: Law, Memory, and Emancipation in Post-Apartheid South Africa, Stanford: Stanford University Press, 2016). 


\section{Human Rights and Education Reform during Political Transition}

Education was central to the apartheid government's efforts to entrench the discriminatory practices initiated under colonialism and to institutionalize the political, social, and economic marginalization of the majority black population. In a 1953 speech on the Bantu Education Act, which effectively created a parallel education system for black South Africans, then Education Minister H. F. Verwoerd asserted,

The school must equip the Bantu to meet the demands which the economic life will impose on him.... There is no place for him in the European community above the level of certain forms of labour. ... What is the use of teaching a Bantu child mathematics when it cannot use it in practice?

Apartheid-era education policies ensured that black South Africans had less access to schooling and received an inferior education in under-resourced institutions with poor facilities. ${ }^{4}$ They also promoted the myth of white superiority and black inadequacy, teaching, as post-apartheid Education Minister Naledi Pandor noted, "white learners to see themselves as part of a larger world, while black learners were taught to accept the confines of their racial and ethnic enclaves."

Although the TRC found that the deprivation of adequate education was a cornerstone of apartheid and itself a human rights violation, the commission did not address the education system in depth. This is largely because the TRC focused on gross violations of civil and political rights, particularly relating to bodily integrity, rather than on violations of social and economic rights or the historical injustices that characterized apartheid. The commission viewed itself as but one of a number of government and civil society institutions established to address the legacies of past oppression. ${ }^{6}$ As a result of its resource and time constraints, the TRC made general recommendations regarding the need for transformation in education and for a human rights culture to be built through the mainstreaming of human rights education in schools. ${ }^{7}$ It left the detailed

3 Quoted in A. N. Pelzer, ed., Verwoerd Speaks: Speeches 1948-1966 (Johannesburg: APB Publishers, 1966), 83.

4 Each racial group had its own education system under apartheid, with "white" students having access to high-quality and compulsory schooling, "coloured" and "Asian/Indian" students to compulsory schooling of a lesser quality, and "Bantu" students to inferior and non-compulsory schooling.

5 Grace Naledi Pandor, "Educating the Nation," in After the TRC: Reflections on Truth and Reconciliation in South Africa, edited by Wilmot James and Linda van de Vijver (Athens: Ohio University Press, 2001), 187.

6 Madeleine Fullard and Nicky Rousseau, "Uncertain Borders: The TRC and the (Un)Making of Public Myths," KRONOS: Southern African Histories 34, no. 1 (2008): 215-239.

7 This focus on human rights education is common among truth commissions. See Clara 
thinking on education reform to other institutions, as it did with most structural issues.

The commission has since been criticized for not including the education sector in its institutional hearings, which - in order to complement public hearings where individual victims and perpetrators gave testimony - were designed to encourage institutions working in sectors such as health, media, religious communities, and business and labor to acknowledge the extent of their collaboration with the apartheid regime. The argument is that a special hearing on education might have highlighted the structural inequalities engendered by apartheid, provided insight into victims' experiences, and led to more specific recommendations, an implementation plan, and partnerships among bodies involved in implementation, including the Department of Education. ${ }^{8}$ As it was, little testimony was heard regarding education, with most participants in the victims' hearings focusing on loss of schooling as a result of events or traumas of apartheid, rather than on the failures and injustices of the education system itself. $^{9}$

Already in 1998, members of Khulumani Support Group, then focused on following the work of the TRC, identified education as one of the areas the commission must address. Among their recommendations to the TRC as it drafted its final report, members included the following:

Human rights education: We recommend that the history of South Africa be presented by school textbooks in such a manner that the suffering of victims across the political spectrum be recognised. The horrendous impact of both the system of apartheid, as well as the violence that destroyed communities, should be sensitively portrayed. In this regard, the TRC should write recommendations that fit in with current re-structuring of the Education Department and ideas for a new curriculum. Similarly, we recommend that programmes that provide intensive human rights education to the general public be encouraged and institutionalised within our schools and universities. Human rights education should start at as an early age as possible. ${ }^{10}$

While Khulumani members at the time noted the need for apartheid to be recognized as an abusive system beyond individual rights violations, and stressed the need for specific recommendations on education, their demands in

Ramírez-Barat and Roger Duthie, Education and Transitional Justice: Opportunities and Challenges for Peacebuilding (New York: ICJT and UNICEF, 2015).

8 Veerle Dieltiens, Learning Anew: Truth and Reconciliation in Education (Johannesburg: Centre for the Study of Violence and Reconciliation, 2005).

9 Ibid.

10 Centre for the Study of Violence and Reconciliation and Khulumani Support Group, "Survivors' Perceptions of the Truth and Reconciliation Commission and Suggestions for the Final Report," 1998, http://www.csvr.org.za/index.php/publications/1705-submission-tothe-truth-and-reconciliation-commission-survivors-perceptions-of-the-truth-and-reconci liation-commission-and-suggestions-for-the-final-report.html, accessed 17 January 2018. 
this respect were limited to the mainstreaming of human rights education in the curriculum. They did not recommend that the TRC push for victim participation in education reform, nor did Khulumani publicly seek to work with the Department of Education on developing the new curriculum. Having acknowledged the importance of education, Khulumani, much like the TRC, left the specifics of education reform to post-apartheid government institutions and civil society organizations that specialized in the field. Given its focus on reparations, and in response to victim testimonies before the TRC, Khulumani began lobbying the government to provide financial assistance to victims and their family members to gain access to educational opportunities. ${ }^{11}$

As the TRC was doing its work, the Department of Education was already in the process of developing a new curriculum "infused" with human rights as articulated in the new South African constitution. After being critiqued for adopting a future-oriented curriculum that was, as Linda Chisholm argues, "a compromise between old and new forces [in which] new values to which all could subscribe were articulated [and] the social content of the curriculum was underplayed," 12 the department revised the curriculum to engage more directly with the human rights abuses of the past and their legacies, starting in Grade 4. This included the introduction of lessons on apartheid history and the TRC in Grade 9 and, in more detail, in Grade $11 .{ }^{13}$ While victim testimonies were used in these lessons and in various supplementary teaching resources on the TRC produced in a civil society context, Khulumani was not directly involved in the development of this educational material. ${ }^{14}$ Khulumani undertook a variety of informal educational activities that evolved over time, as will be detailed below, but its engagement with reforms in the formal education system was largely limited to the above-mentioned call for human rights mainstreaming.

The emphasis on human rights displayed by the TRC, victims, and the De-

11 Oupa Makhalemele, Southern Africa Reconciliation Project: Khulumani Case Study (Johannesburg: Centre for the Study of Violence and Reconciliation, 2004). This was also one of the TRC's recommendations.

12 Linda Chisholm, "The State of Curriculum Reform in South Africa: The Issue of Curriculum 2005," in State of the Nation: South Africa 2003-2004, edited by John Daniel, Adam Habib, and Roger Southall (Cape Town: Human Sciences Research Council Press, 2003), 272. This included avoiding the crisis in the subject of history, which previously had been used to promote colonial and apartheid ideology, by integrating it into a general Human and Social Studies learning area.

13 For an analysis of truth and reconciliation in education in South Africa, see in particular Dieltiens, Learning Anew. Also see Penny Enslin, "Citizenship, Identity and Myth: Educational Implications of South Africa's Truth and Reconciliation Commission," Change: Transformations in Education 3, no. 1 (2000): 80-90.

14 For example, Institute for Justice and Reconciliation, Truth Justice Memory: DVD and Teacher Guide (2008); Choices Program, "Freedom in Our Lifetime: South Africa's Struggle," http://www.choices.edu/resources/detail.php?id=35, accessed 17 January 2018. 
partment of Education following the end of apartheid reflects the increasing reliance on human rights discourse that accompanied, and to some extent grew out of, political transitions as the Cold War came to an end. Human rights discourse was a way to grasp and discuss the complex shifts in values, social relations, and notions of citizenship that attended these changes in the local and global political order. As Paige Arthur has argued, human rights gained currency globally in the context of the decline of left-wing political movements and thought with the fall of the Berlin Wall, and the attendant increase in the relevance of democratic systems, preference for rapid legal-institutional reform over theories of long-term socioeconomic "modernization," and move from structural analyses of social change to an emphasis on agency and choice. ${ }^{15}$ In the South African transitional context, the idea of a human rights culture suggested a decisive break with the abuses of apartheid and the advent of a new order consisting of active citizenship, social transformation, reconciliation, and a common political identity. ${ }^{16}$

Yet, in its connection with transitional justice, the human rights discourse has proved inadequate in addressing historical and structural injustices that hinder real transformation, given both its historical focus on civil and political rights and its post-Cold War application as a tool of abrupt legal-institutional reform. In addition, human rights discourse in transitional contexts, combined with the increasing emphasis on individual agency over structural change noted by Arthur, legitimizes not only political liberalization but also economic liberalization. ${ }^{17}$ In this context, human rights and transitional justice as practiced in most countries, while containing the potential for enabling social transformation and greater equality, have become instrumental to the spread of the neoliberal free market paradigm and its focus on individual competitiveness, as well as its attendant increases in socioeconomic inequality and tendency to deepen historical and structural marginalization. ${ }^{18}$

Although education in transitional justice contexts has received limited attention, ${ }^{19}$ education reform is a site where the conservative implications of the interaction of transitional justice, human rights, and liberalization are visible. As is demonstrated in the next section, the rapid institutional reform that accom-

15 Paige Arthur, "How 'Transitions' Reshaped Human Rights: A Conceptual History of Transitional Justice," Human Rights Quarterly 31 (2009): 321-367.

16 Enslin, "Citizenship, Identity and Myth."

17 Rosemary Nagy, "Transitional Justice as Global Project: Critical Reflections," Third World Quarterly 29, no. 2 (2008): 275-289.

18 Paul Gready and Simon Robins, "From Transitional to Transformative Justice: A New Agenda for Practice," International Journal of Transitional Justice 8, no. 3 (2014): 339-361. See also William Davies, The Limits of Neoliberalism: Authority, Sovereignty and the Logic of Competition (Thousand Oaks: Sage, 2014).

19 Ramírez-Barat and Duthie, Education and Transitional Justice. 
panies political transitions often fails to take into account the socioeconomic legacies of the previous period, and as a result the change is often more symbolic than actual, a nod to international norms rather than a response to local specificities. This approach prioritizes what Paul Gready and Simon Robins describe as "the creation of institutions over a contextualized engagement with the welfare of the population, creating 'empty' organizations paralyzed by a lack of capacity rather than responding to the everyday needs of the new state's citizens." ${ }^{20}$

Discussing the South African education system, Jonathan Jansen has similarly argued that the state after the political transition was preoccupied with "settling policy struggles in the political domain rather than in the realm of practice,"21 which accounts for much of the disconnect between educational policy and implementation. As the following brief history of curriculum reform demonstrates, this is particularly clear in regard to human rights education in South Africa.

\section{Human Rights Education, Curriculum Reform, and New Citizens in South Africa}

Post-apartheid educational reform was a response to the country's "transitional moment" but also emerged from long-standing efforts to challenge the apartheid education system. In fact, education was long a site of struggle in South Africa, with examples including resistance to segregated schooling under colonialism, the establishment of alternative schools for black workers in the early twentieth century, the establishment of independent schools for black students in the 1940s, and frequent unrest after the passing of the Bantu Education Act that culminated in the 1976 Soweto student uprising and massacre, today commemorated as Youth Day. ${ }^{22}$ Subsequent school boycotts around the country led educationalists, activists, politicians, and other stakeholders into a public debate regarding the future of education in South Africa that by the mid-1980s coalesced into a broad-based movement for People's Education.

People's Education as a concept was characterized by an emphasis on collective experience and a "culture of sharing"; knowledge arising from organization and action; education being political; respect for ordinary people's knowledge and skills; and education being empowering and leading to trans-

20 Gready and Robins, "From Transitional to Transformative Justice," 341.

21 Jonathan Jansen, "Political Symbolism as Policy Craft: Explaining Nonreform in South African Education after Apartheid," Journal of Education Policy 17, no. 2 (2002): 199-215.

22 Peter Kallaway, ed., The History of Education under Apartheid, 1948-1994 (New York: Peter Lang, 2002); Rehana Muhammad, "The People's Education Movement in South Africa: A Historical Perspective," MA thesis (Rand Afrikaans University, 1996). 
formation. ${ }^{23}$ Although participants disagreed on whether the movement was an effort to design a new education system, an approach to encouraging critical thinking and dialogue on the meaning of education while acknowledging everyday realities in marginalized communities, or even a method for political mobilization, ${ }^{24}$ People's Education was generally understood as "education that puts people in command of their lives" to the extent that "every initiative must come from the people themselves and must advance the broad mass of students, not just a select few." 25 This gave rise to the movement's slogan: "people's education for people's power." While it very much emerged from South African responses to exclusionary education, People's Education was also influenced by Paulo Freire's Pedagogy of the Oppressed. ${ }^{26}$

As André Keet and Nazir Carrim argue, the principles of People's Education shaped the post-apartheid understanding of human rights education. They note that "constructions of [human rights education] within curricula across the world are determined by particular historical, social, economic and political trajectories and encompassed by the idea of a human rights culture." ${ }^{27}$ In South Africa, this meant a focus on reconciliation, active citizenship, equality through social transformation, and the construction of a common political identity. Human rights education, with its promotion of social change and reference to Freire's work, seemed like an organic and legitimate outgrowth of apartheid-era attempts at inclusive education. Human rights education was also, like transitional justice, an increasingly accepted international norm that signalled a state's "maturation" into a democracy and that was applied particularly in countries undergoing political transition. ${ }^{28}$

While the rationale for including human rights education in the new curriculum had clear links to the past in South Africa, the fact that human rights education as a subject is not clearly defined, either conceptually or in practice, allowed it to be implemented in a manner that in many ways fell short of the principles of People's Education. As outlined by Nancy Flowers, this is an issue endemic to human rights education globally, as different stakeholders have different understandings of what it actually means and what its role in social

23 Linda Cooper, "The Implications of the National Qualifications Framework for Emancipatory Education in South Africa," in Reconstruction, Development and the National Qualifications Framework (Johannesburg: Centre for Education Policy Development, 1998).

24 Glenda Kruss, People's Education: An Examination of the Concept (Bellville: Centre for Adult and Continuing Education, University of the Western Cape, 1988).

25 Zwelakhe Sisulu, quoted in ibid., 18.

26 Paulo Freire, Pedagogy of the Oppressed, trans. Myra Ramos (New York: Continuum, 1968).

27 André Keet and Nazir Carrim, "Human Rights Education and Curricular Reform in South Africa," Journal of Social Science Education 5, no. 1 (2006): 91.

28 Felisa Tibbitts and Peter G. Kirchschlaeger, "Perspectives of Research on Human Rights Education," Journal of Human Rights Education 2, no. 1 (2010): 8-29. 
change could be. According to Flowers, while governmental definitions of human rights education tend to center on the role of the state and on preserving order and continuity, interpretations within civil society tend to be more varied and to stress transformation, critical thinking, and grassroots experiences and solutions, at times in opposition to the state order. ${ }^{29}$ This dynamic can be seen in education as well as other policy areas in South Africa, where most assumed that the post-apartheid government and other institutions would follow through on transformative agendas outlined during the struggle period, particularly as many anti-apartheid activists entered the government in the 1990s. As noted above, this expectation certainly informed the TRC's work. After the political transition, however, the negotiated settlement and governmental interests gave rise to conservative interpretations of reform that once more rendered education policy formation and implementation sites of contestation.

Human rights education and the development of a human rights culture in education encompass many elements, including policy formation, curriculum and educational materials development, management, budgeting, ensuring access to schooling, and taking into account teacher and student capacities. Each of these elements comes with a host of challenges, ${ }^{30}$ the most salient of which for the purposes of this chapter is the tension created by the combination of political and economic liberalization that attends transitional justice, and how it manifests in education.

On a practical level, the South African government has been attempting to address apartheid-era inequality by guaranteeing access to quality education for previously marginalized communities. At the same time, however, it has also adopted a neoliberal framework that demands budget cuts as part of a smaller role for government, the establishment of independent school-governing bodies which in an effort to ensure high-quality education set school fees that exclude many students, and the adoption of an international model of outcomes-based education that has faced implementation problems, for example due to teacher and student capacity emerging from apartheid-era inequality. ${ }^{31}$ Although improvements have been made overall to the education system, the socioeconomic make-up of most schools and the communities in which they are based has not changed since apartheid.

With regard to a human rights culture, the government has reformed the

29 Nancy Flowers, “What Is Human Rights Education?" in A Survey of Human Rights Education (Gütersloh: Bertelsmann Verlag, 2003), 107-118.

30 For more on education reform in post-apartheid South Africa, see Kallaway, The History of Education; Dieltiens, Learning Anew; Linda Chisholm, "The State of South Africa's Schools," in State of the Nation: South Africa 2004-2005, edited by John Daniel, Roger Southall, and Jessica Lutchman (Cape Town: Human Sciences Research Council Press, 2005), 201-226.

31 Chisholm, "The State of South Africa's Schools." 
curriculum so as to teach post-apartheid citizens reparative values based on reconciliation, equality, and solidarity in commonality, while simultaneously teaching individual competitiveness and productivity in the South African and the global economy that promotes the image of "pulling oneself up by one's bootstraps." ${ }^{\text {"2 }}$ As noted in Daniel Hammett and Lynn Staeheli's study of citizenship education in South African schools, students in well-resourced schools see little direct evidence around them of the inequality that must be addressed, while students in historically under-resourced schools must reconcile discussion of human rights and economic opportunity with their lived reality of struggling to pay school fees and the low likelihood of finding employment even in the event of graduating. ${ }^{33}$ Although the curriculum acknowledges apartheid-era oppression, it is forward-looking to the extent that the continuities between past and present inequalities are masked and the onus of both ensuring and embodying human rights while also creating economic opportunity for oneself is individualized. ${ }^{34}$ Rather than being taught to accept the confines of their racial and ethnic enclaves as they were under Bantu Education, ${ }^{35}$ most post-apartheid black students are taught that their inability to access the job market and improve their family's living conditions is more a result of individual failure than of structural constraints, ${ }^{36}$ and in fact that structural constraints are no longer a sociopolitical issue.

The Department of Education linked values and market readiness in its 2001 Manifesto on Values, Education and Democracy, noting that

being educated for "meaningful participation in society" means being educated for the marketplace as much as for good citizenship and that, indeed, productivity and responsibility are interdependent. ... We educate young people not only for the market but for good citizenship, too. ${ }^{37}$

The Manifesto thereby both asserts the relationship and acknowledges the potential tension between the two. While the Manifesto outlines very broad strategies for incorporating values, good citizenship, and human rights into education, it offers little specific guidance on how to actually teach these, particularly as human rights are not a separate subject but rather are intended to be "infused" throughout the curriculum. ${ }^{38}$

32 Keet and Carrim, "Human Rights Education."

33 Daniel Hammett and Lynn A. Staeheli, Citizenship Education in South Africa: A Report to Schools (Swindon: Economic and Social Research Council, 2009).

34 Salim Vally, "From People's Education to Neo-Liberalism in South Africa," Review of African Political Economy 34 (2007): 39-56.

35 Pandor, "Educating the Nation."

36 Vally, "From People's Education."

37 Department of Education, Manifesto on Values, Education and Democracy (2001), 11.

38 For example, the document cites previous research on infusing human rights into the cur- 
In 2005, the Department of Education attempted to concretize human rights education with a guide on Values and Human Rights in the Curriculum, which offers direction on how to use a variety of teaching materials to illustrate and encourage critical thinking about human rights. The guide recommends using materials such as apartheid-era newspaper clippings and post-apartheid images of townships to generate discussion of, for example, inequality, discrimination, and exploitative practices in business. ${ }^{39}$ While issues of social justice are raised, the guide is an example of the governmental approach to human rights education, highlighting the role of the state, the importance of order, and approaches to social justice that focus on mutual tolerance, common political identity, individual responsibility, and reform, as opposed to substantive redress and transformation. ${ }^{40}$

This brief discussion of human rights education suggests how the postapartheid government adopted educational policies that did not take into account the socioeconomic realities of South Africa or how these would undermine the reforms, creating another largely "empty" institution along the lines argued by Gready and Robins, as noted above. ${ }^{41}$ These socioeconomic realities emerged from apartheid, but they have become more entrenched through the free market paradigm and its focus on individual competitiveness in the democratic period. While the inclusion of human rights education symbolically signals a break with past abuses and the government's commitment to transformation through the incorporation of international norms, the way in which it has been implemented in the transitional context undermines the principles and efforts towards social change from which the human rights education approach emerged. In contrast, the next section shows how Khulumani members have used their positionality as victims, activists, and members of marginalized communities to raise public and youth awareness of increasing social inequality and of the continuities between apartheid-era and post-apartheid socioeconomic exclusion. They have thus adopted an approach to human rights education that is closer to the transformative principles of People's Education.

riculum, stating, "In the natural sciences, students will be encouraged to understand environmental issues and allied human rights concerns that go with them," but without specifying how this would be operationalized. Ibid., 26.

39 Department of Education, Values and Human Rights in the Curriculum: A Guide (2005).

40 This orientation is prevalent throughout the document (ibid.). An example is the guide's approach to geography, which focuses on increasing students' "critical awareness of issues of fairness, equity and justice" (128), with specific reference to socioeconomic rights and sustainable development. The guide fails to link the legacy of apartheid-era segregation and forced removals to the socioeconomic marginalization of areas previously earmarked for populations classified as "non-white," and also neglects grassroots efforts to address this marginalization.

41 Gready and Robins, "From Transitional to Transformative Justice," 341. 


\section{Khulumani's Contributions to (People's) Education}

As described above, Khulumani's engagement with the formal educational reform process in South Africa has been limited to lobbying for financial assistance for education as a form of reparation and recommending the mainstreaming of human rights education in the curriculum. While Khulumani did not participate in the reform process, it did begin engaging in public education campaigns soon after its formation. Over time, this evolved into informal educational activities - ranging from mentoring youth arts groups and organizing youth dialogues to offering training in "citizen journalism" - with an increasing focus on socioeconomic exclusion as a legacy of apartheid. While Khulumani's educational work calls for further research, this short chapter offers a close reading of Khulumani's public statements in order to demonstrate the organization's links to People's Education, which has implications for human rights education in the South African and other transitional contexts.

Khulumani's early public education campaigns took the form of demonstrations and submission of demands to the government, raising awareness through the media, and the recruitment and mobilization of new members. In time, the organization developed two memory projects, the 1997 performance piece "The Story I Am About to Tell," which saw founding members of Khulumani participating in the writing and performance of a play about their experiences under apartheid, and the 2004 exhibition "Breaking the Silence: A Luta Continua," which presented artwork by Khulumani members depicting the effects of apartheid-era traumas on their bodies and lives. The projects had both developmental and dialogic elements, encouraging the sharing of experiences among members through storytelling with a view to building solidarity and facilitating healing as well as promoting dialogue in their audiences on the often hidden realities and legacies of apartheid..$^{42} \mathrm{~A}$ later showing of "Breaking the Silence" explicitly stated the organization's educational goals, noting that the exhibition aimed "to give the unacknowledged heroes and survivors of the struggle against apartheid a chance to remember and express their experiences, and to create a record that might honour their sacrifice and educate future generations." ${ }^{\prime 3}$

42 See April Sizemore-Barber, "Stages of Complicity, Stages of Healing: A Look at Two Theatrical Responses to South Africa's Truth and Reconciliation Commission," and Kay Schaffer, "Memory Work and Memorialisation in the New South Africa," in Pumla Gobodo-Madikizela and Chris Van Der Merwe, eds., Memory, Narrative and Forgiveness: Perspectives on the Unfinished Journeys of the Past (Cambridge: Cambridge Scholars Publishing, 2009).

43 Khulumani, "Breaking the Silence: A Luta Continua - An Exhibition of Memory and Healing Work," 10 June 2011, http://www.khulumani.net/component/k2/item/484-breaking-the-si 
In the mid-2000s, after the closing of the TRC, Khulumani decided to expand its work beyond "apartheid atrocities" and engage with current human rights issues, including socioeconomic rights. ${ }^{44}$ In 2009-2010, this evolved into a strategic focus on promoting "socioeconomic transformation" in victims' lives. ${ }^{45}$ Khulumani's public education activities accordingly began to engage with post-apartheid realities and the challenges of poverty and inequality faced by members in their families and communities. Acknowledging the intergenerational impact of apartheid-era oppression as well as post-apartheid marginalization, Khulumani also began working explicitly with youth, including children, adolescents, and people in their early 20 s, engaging in informal educational activities that emphasized intergenerational dialogue and learning. These new activities have highlighted Khulumani members' awareness of the continuities between past and present exclusion as well as their own resilience, solutions to problems, and roles as educators for young people.

Khulumani's national director Marjorie Jobson acknowledged this shift in the organization's approach, noting that, in the late 2000s, members increasingly asserted "their perspectives and contributions to the continuing struggle to build a society based on 'democratic values, social justice and fundamental human rights' in which the quality of life of all citizens is progressively improved." 46 In a personal essay published on the organization's website, Khulumani's national coordinator NomaRussia Bonase went further in articulating the shift:

In my community, we see inequalities which stand at the roots of our lives: the poverty of information, the poverty of justice, the poverty of skills; all of these inter-relate with the poverty of fundamental needs - we lack food, water, housing, even a clean environment. These poverties build upon each other. Even if you have food and water, if you do not have information and skills and access to justice, you cannot come up with ways to create a better life. ... We fought apartheid to create a system where our people can discuss and debate, and vote for our own government. Now, we need forums and structures which create space to explore ideas and possibilities to work through to completion.... Our vision is that in ten years time poverty should be alleviated. But this will depend upon what we do, whether we can implement our strategies and tactics, and make fundamental changes in our lives. ${ }^{47}$

lence-a-luta-continua-an-exhibition-of-memory-and-healing-work.html, accessed 17 January 2018.

44 Khulumani, "Resolutions: National Steering Committee Meeting," internal document (2006), 3.

45 Email communication, Khulumani national director, 1 August 2017.

46 Khulumani, Annual Report, 2012-2013 (2013), 4. Emphasis in original, referencing the Preamble to South Africa's constitution.

47 Khulumani, "Exploring My Thinking on Poverty - An Essay," 16 August 2010, http://www. khulumani.net/active-citizens/item/511-exploring-my-thinking-on-poverty-an-essay.html, 
Khulumani has employed a range of strategies in addressing post-apartheid socioeconomic exclusion, such as working with a community in Eastern Cape Province on accessing clean water and supporting the widows of striking miners killed by police at Marikana through memory projects and advocacy aimed at improving living conditions. ${ }^{48}$ However, much of Khulumani's work in this regard has consisted of informal educational activities with young people. Examples include mentoring youth arts groups, involving youth in arts and crafts projects aimed at capacity building and income generation, training community-based "citizen journalists," organizing youth dialogues on apartheid legacies, and holding workshops with secondary-school students on issues such as active citizenship, community organizing, and healthy sexual relationships. ${ }^{49}$

More specifically, in 2010, Khulumani began working with Officially Offside, a group of young community activists in Grahamstown in Eastern Cape Province who use art forms such as music, performance, and comics to encourage "social interaction and political conscientising" and to support young people to, as activist Xolile Madinda notes,

find our freedom in our art to take back the capacities that seem to have been taken from people and communities. Apartheid caused the destruction of our communities and also the capacities of people to think for themselves and to direct their own lives. Finding the stories of Khulumani Support Group has been a blessing to us as the youth. ${ }^{50}$

In 2012, the organization formed the Khulumani Forum Theatre Group, training young people in Soweto in Gauteng Province to develop performance pieces based on dialogue with Khulumani members and addressing topics such as reparations, identity, and the effects of HIV/AIDS. This form of community interactive theatre is informed by Augusto Boal's theatre of the oppressed, itself influenced by Paulo Freire's thinking. It aims to educate young people, draw on Khulumani members' experiences as victims and as community-based activists, and to encourage dialogue in the communities where the pieces are performed. ${ }^{51}$

accessed 17 January 2018. In 2017, Ms. Bonase received the Anne Klein Women's Award from the Heinrich Böll Foundation for her women's rights activism.

48 See Khulumani.net.

49 Khulumani, “Some Examples of Khulumani’s Active Citizenship,” 16 July 2010, http://www. khulumani.net/active-citizens/item/394-some-examples-of-khulumanis-active-citizenship. html, accessed 17 January 2018. See also more examples in the "Active Citizenship" and “Truth and Memory" archives on Khulumani's website.

50 Quoted in Khulumani, “Acoustic Soul Presents: Freedom Express!” 23 April 2012, http:// www.khulumani.net/active-citizens/item/650-acoustic-soul-presents-freedom-express-25april-makhayas-lodge-fingo-township-grahamstown.html, accessed 17 January 2018.

51 Khulumani, “Appreciation for Mouhamadou Diol's Work at the Khulumani Forum Theatre Group,” 26 July 2012, http://www.khulumani.net/active-citizens/item/676-appreciation-for- 
In 2014, Khulumani organized a Youth Day PhotoWalk with students based in Soweto to examine the extent to which young people understand what happened during the Soweto uprising and identify gaps in the teaching of history in schools. ${ }^{52}$ In 2017, Khulumani began designing a research-based advocacy project to improve the education, healthcare, and housing situations of victims' families in Western Cape Province, which includes intergenerational dialogues with an educational bent between elderly Khulumani members and their younger family members. ${ }^{53}$

These examples demonstrate ways in which Khulumani's informal educational activities link the past and the present, emphasizing the value of members' experiences as apartheid-era victims and as post-apartheid activists, as well as encouraging youth and their communities to use their knowledge to effect change. In particular, they are rooted in ordinary people's lived experiences, with initiatives designed and implemented by participants based on their stories. Here, Khulumani members are seen as embedded in their communities, both empowered and empowering others, particularly youth, to address immediate and structural problems and to see themselves as collectively instrumental in social transformation. As such, Khulumani follows firmly in the tradition of People's Education. ${ }^{54}$

In line with Flowers' argument that state approaches to human rights education tend to be more conservative than those from civil society, ${ }^{55} \mathrm{Khulumani} \mathrm{s}$ educational activities demonstrate a more transformative vision of human rights education than that displayed in the formal curriculum, encouraging critical thinking, learning from ordinary people's experiences, and validating grassroots solutions while explicitly using and connecting the language of human rights and social transformation within the framework of intergenerational exchange and learning. ${ }^{56}$ The organization's educational activities often stress autonomy from

mouhamadou-diols-work-at-the-khulumani-forum-theatre-group.html, accessed 17 January 2018.

52 Khulumani, "Report on the Khulumani National Youth Day Photowalk in Soweto on 16 June 2014," 4 July 2014, http://www.khulumani.net/truth-memory/item/978-report-on-the-khu lumani-national-youth-day-photowalk-in-soweto-on-16-june-2014.html, accessed 17 January 2018.

53 Yanelisa Sishuba, Sindiswa Nunu, Nompumelelo Njana, Agnes Ngxukuma, Brian Mphahlele, and Jasmina Brankovic, Conducting Participatory Action Research with Apartheid Survivors: Lessons from "Addressing Socioeconomic Drivers of Violence in Khulumani Communities" (Cape Town: Khulumani Support Group Western Cape and Centre for the Study of Violence and Reconciliation, 2017).

54 See Cooper, "The Implications of the National Qualifications Framework."

55 Flowers, "What Is Human Rights Education?"

56 For example, Jobson has noted that "central to [Khulumani's] advocacy efforts is the focus on measures for socioeconomic transformation of the lives of victims through efforts to facilitate access to equal rights, resources and power. ... Khulumani is committed to remem- 
the state, which, in combination with its demands for redress from government - frequently through adversarial tactics such as demonstrations and challenges in the media - question the state order as it currently stands. Demonstrating the impact of this approach to human rights education, a Grade 12 student, Pretty Masombuka, at the 2011 Khulumani Mpumalanga Victim Empowerment for Active Citizenship Workshop asserted, "We are born free and equal. We all have the right to freedom of expression. This means that we are free to think and to share what we think." 57

\section{Victims' Groups and Education in Transition}

Khulumani Support Group's informal educational activities are part of its work of addressing the "unfinished business" of the TRC and highlighting that South Africa's transition is ongoing. After the TRC closed in the early 2000s, Khulumani decided to expand its work on redress for past abuses to current human rights issues, as well as to engage with young people. Both decisions point to its increasing concern with the persistence of historical and structural injustices after the shift to democracy and with the intergenerational effects of socioeconomic marginalization on victims and their families and communities. With these decisions, the organization demonstrated an awareness that apartheid-era struggles for inclusion and transformation would not end with the change in government or with the legal-institutional reforms that accompanied the transitional justice process, despite expectations to the contrary shared by most South Africans in the 1990s.

Khulumani in effect queries the ways in which human rights and transitional justice are practiced in most transitional contexts, including their contribution to the rise of economic liberalization and a culture of competitiveness, which do not address, and in fact often exacerbate, historical injustices and structural inequality. This chapter has argued that educational reform in countries undergoing political transition is a site where the conservative implications of the interaction of transitional justice, human rights, and economic liberalization

bering and honouring the committed actions of its members and to creating opportunities for intergenerational exchanges to inform understandings of the present with this knowledge and experiences." Quoted in Khulumani, "Living with the Past: Remembering Dis(re)membering and Ideals of Justice," 11 June 2011, http://www.khulumani.net/truth-me mory/item/489-living-with-the-past-remembering-disremembering-and-ideals-of-justice. html, accessed 17 January 2018.

57 Khulumani, "Grade 12 Learner Speach at Active Citizenship Workshop, Mpumalanga," 1 April 2011, http://www.khulumani.net/active-citizens/item/446-grade-12-learner-speachat-active-citizenship-workshop-mpumalanga.html, accessed 17 January 2018. 
become visible. The discussion of Khulumani's informal educational activities, specifically as an example of a civil society-driven approach to human rights education that stands in contrast to state-driven efforts and that questions state order in its current form, has attempted to show an alternative engagement with human rights and transitional justice that has more transformative potential.

The chapter invites the question as to whether state institutions and reforms necessarily stress order and continuity, and whether it is therefore the role of civil society, social movements, and ordinary citizens to push a more transformative agenda, at least in today's global economic and political environment. Do the latter need to be on the "outside" in order to promote and effect substantive change? Looking at education reform in transitional contexts, could victims' groups like Khulumani push a transformative agenda if they worked with the government to develop new curricula, particularly within human rights education?

To date, victims have been included in curricula primarily in the form of their stories. Victims' experiences as articulated in testimony before truth commissions or courts, in media accounts, or in civil society knowledge products, are used to root lessons in real experience and to promote dialogue among students, as well as to represent human rights abuses. While victims' stories are valuable as an educational tool - and Khulumani accepted this by recommending in 1998 that victims' experiences be "sensitively portrayed" in school textbooks ${ }^{58}$ - this approach places victims in the familiar position of passivity. In most teaching materials, victims are frozen in the moment of their victimization or in the moment of first articulating their experience of victimization in public. Their experience in other roles, particularly as agents of change, is eclipsed by their positionality as subjects of transitional justice policies. ${ }^{59}$ In addition, abuses are framed as occurring in the past and not the present, while transition is portrayed as a time-bound event rather than an ongoing process with stakeholders negotiating political, social, and economic realities long after the moment of political transition from authoritarianism or conflict. The context of victims' experiences and stories is not provided by the victims themselves.

Victims' groups are in a position to frame and present victims' stories in a way that highlights a holistic view of human rights and challenges pre-transition historical narratives, as well as emphasizing continuities between the past and present. In most transitional contexts, they are in a position to demonstrate the relevance of socioeconomic rights and to challenge hierarchies of victimhood

58 CSVR and Khulumani, "Survivors' Perceptions."

59 For insights into agency and victimhood, see Gudrun Dahl, "Sociology and Beyond: Agency, Victimisation and the Ethics of Writing," Asian Journal of Social Science 37 (2009): 391-407; Tessa Lacerda, “Victim': What Is Hidden Behind This Word?" International Journal of Transitional Justice 10 (2016): 179-188. 
promoted by the traditional emphasis on civil and political rights violations, providing a broader view of who suffered pre-transition harms. They can show the importance of addressing historical and structural injustices through ongoing transitional justice efforts and through government institutions and policies in order to prevent their reoccurrence. This approach could place victims at the center of ongoing transitions rather than on the periphery of transitional justice. ${ }^{60}$

The choice between collaborating with government on formal education reform or working on informal educational activities may be a false one, as victims' groups could work with government while at the same time undertaking independent educational activities, collaborating with other civil society groupings on supplementary teaching materials, or taking another route. In any case, the role of victims' groups in education as well as the relationship between transitional justice and education call for additional research given that education throws into relief many of the challenges of political transition in the age of human rights.

\section{Bibliography}

Arthur, Paige. "How 'Transitions' Reshaped Human Rights: A Conceptual History of Transitional Justice." Human Rights Quarterly 31 (2009): 321-367.

Bonase, NomaRussia. "Exploring My Thinking on Poverty - An Essay." 16 August 2010, http://www.khulumani.net/active-citizens/item/511-exploring-my-thinking-on-pov erty-an-essay.html. Accessed 17 January 2018.

Bundy, Colin. "The Beast of the Past: History and the TRC." In After the TRC: Reflections on Truth and Reconciliation in South Africa, edited by Wilmot James and Linda van de Vijver. Athens: Ohio University Press, 2001.

Centre for the Study of Violence and Reconciliation and Khulumani Support Group. "Survivors' Perceptions of the Truth and Reconciliation Commission and Suggestions for the Final Report." 1998. http://www.csvr.org.za/index.php/publications/1705-sub mission-to-the-truth-and-reconciliation-commission-survivors-perceptions-of-thetruth-and-reconciliation-commission-and-suggestions-for-the-final-report.html. Accessed 17 January 2018.

60 See Simon Robins, "Towards Victim-Centred Transitional Justice: Understanding the Needs of Families of the Disappeared in Postconflict Nepal," International Journal of Transitional Justice 5 (2011): 75-98. Clearly this would be a simpler project with a unified national victims' group, such as Khulumani. Many transitional contexts have multiple and at times contesting victims' groups with varying demands as a result of different cycles of violence and their effects on different population groups. The line between perpetrator and victim is frequently blurred. The relationship between the state and victims' groups is also often adversarial. Finally, the urge to romanticize or overburden victims' groups must be acknowledged. 
Chisholm, Linda. "The State of Curriculum Reform in South Africa: The Issue of Curriculum 2005." In State of the Nation: South Africa 2003-2004, edited by John Daniel, Adam Habib, and Roger Southall. Cape Town: Human Sciences Research Council Press, 2003.

Chisholm, Linda. “The State of South Africa's Schools." In State of the Nation: South Africa 2004-2005, edited by John Daniel, Roger Southall, and Jessica Lutchman. Cape Town: Human Sciences Research Council Press, 2005.

Choices Program. "Freedom in Our Lifetime: South Africa's Struggle." http://www. choices.edu/resources/detail.php id=35. Accessed 17 January 2018.

Colvin, Christopher J. "Shifting Geographies of Suffering and Recovery: Traumatic Storytelling after Apartheid." In Borders and Healers: Brokering Therapeutic Resources in Southeast Africa, edited by Tracy J. Luedke and Harry G. West. Bloomington: Indiana University Press, 2006.

Cooper, Linda. "The Implications of the National Qualifications Framework for Emancipatory Education in South Africa." In Reconstruction, Development and the National Qualifications Framework. Johannesburg: Centre for Education Policy Development, 1998.

Dahl, Gudrun. "Sociology and Beyond: Agency, Victimisation and the Ethics of Writing." Asian Journal of Social Science 37 (2009): 391-407.

Davies, William. The Limits of Neoliberalism: Authority, Sovereignty and the Logic of Competition. Thousand Oaks: Sage, 2014.

Department of Education. Manifesto on Values, Education and Democracy. 2001.

Department of Education. Values and Human Rights in the Curriculum: A Guide. 2005.

Dieltiens, Veerle. Learning Anew: Truth and Reconciliation in Education. Johannesburg: Centre for the Study of Violence and Reconciliation, 2005.

Enslin, Penny. "Citizenship, Identity and Myth: Educational Implications of South Africa's Truth and Reconciliation Commission." In Change: Transformations in Education 3, no. 1 (2000).

Flowers, Nancy. “What Is Human Rights Education?” In A Survey of Human Rights Education. Hamburg: Bertelsmann Verlag, 2003.

Freire, Paulo. Pedagogy of the Oppressed. Trans. Myra Ramos. New York: Continuum, 1968.

Fullard, Madeleine and Nicky Rousseau. "Uncertain Borders: The TRC and the (Un)Making of Public Myths." KRONOS: Southern African Histories 34, no. 1 (2008): 215-239.

Gready, Paul and Simon Robins. "From Transitional to Transformative Justice: A New Agenda for Practice." International Journal of Transitional Justice 8, no. 3 (2014): 339-361.

Hammett, Daniel and Lynn A. Staeheli. Citizenship Education in South Africa: A Report to Schools. Swindon: Economic and Social Research Council, 2009.

Institute for Justice and Reconciliation. Truth Justice Memory: DVD and Teacher Guide. 2008.

Jansen, Jonathan. "Political Symbolism as Policy Craft: Explaining Nonreform in South African Education after Apartheid." Journal of Education Policy 17, no. 2 (2002): 199-215.

Kallaway, Peter, ed. The History of Education under Apartheid, 1948-1994. New York: Peter Lang, 2002. 
Keet, André and Nazir Carrim. "Human Rights Education and Curricular Reform in South Africa." Journal of Social Science Education 5, no. 1 (2006): 87-105.

Kesselring, Rita. Bodies of Truth: Law, Memory, and Emancipation in Post-Apartheid South Africa. Stanford: Stanford University Press, 2016.

Kruss, Glenda. People's Education: An Examination of the Concept. Bellville: Centre for Adult and Continuing Education, University of the Western Cape, 1988.

Khulumani. "Breaking the Silence: A Luta Continua - An Exhibition of Memory and Healing Work." 10 June 2011. http://www.khulumani.net/component/k2/item/484breaking-the-silence-a-luta-continua-an-exhibition-of-memory-and-healing-work. html. Accessed 17 January 2018.

Khulumani. "Resolutions: National Steering Committee Meeting." Internal document. 2006.

Khulumani. Annual Report, 2012-2013. 2013.

Khulumani. "Some Examples of Khulumani's Active Citizenship." 16 July 2010. http:// www.khulumani.net/active-citizens/item/394-some-examples-of-khulumanis-activecitizenship.html. Accessed 17 January 2018.

Khulumani. “Acoustic Soul Presents: Freedom Express!” 23 April 2012. http://www.khuluma ni.net/active-citizens/item/650-acoustic-soul-presents-freedom-express-25-april-makha yas-lodge-fingo-township-grahamstown.html. Accessed 17 January 2018.

Khulumani. “Appreciation for Mouhamadou Diol's Work at the Khulumani Forum Theatre Group.” 26 July 2012. http://www.khulumani.net/active-citizens/item/676-appre ciation-for-mouhamadou-diols-work-at-the-khulumani-forum-theatre-group.html.

Accessed 17 January 2018.

Khulumani. "Report on the Khulumani National Youth Day Photowalk in Soweto on 16 June 2014." 4 July 2014. http://www.khulumani.net/truth-memory/item/978-reporton-the-khulumani-national-youth-day-photowalk-in-soweto-on-16-june-2014.html. Accessed 17 January 2018.

Khulumani. "Living with the Past: Remembering Dis(re)membering and Ideals of Justice." 11 June 2011. http://www.khulumani.net/truth-memory/item/489-living-with-thepast-remembering-disremembering-and-ideals-of-justice.html. Accessed 17 January 2018.

Khulumani. "Grade 12 Learner Speach at Active Citizenship Workshop, Mpumalanga." 1 April 2011. http://www.khulumani.net/active-citizens/item/446-grade-12-learnerspeach-at-active-citizenship-workshop-mpumalanga.html. Accessed 17 January 2018.

Lacerda, Tessa. “'Victim': What is Hidden Behind This Word?" International Journal of Transitional Justice 10 (2016): 179-188.

Makhalemele, Oupa. Southern Africa Reconciliation Project: Khulumani Case Study. Johannesburg: Centre for the Study of Violence and Reconciliation, 2004.

Muhammad, Rehana. "The People's Education Movement in South Africa: A Historical Perspective." MA thesis. Rand Afrikaans University, 1996.

Nagy, Rosemary. “Transitional Justice as Global Project: Critical Reflections.” Third World Quarterly 29, no. 2 (2008): 275-289.

Pandor, Grace Naledi. "Educating the Nation." In After the TRC: Reflections on Truth and Reconciliation in South Africa, edited by Wilmot James and Linda van de Vijver. Athens: Ohio University Press, 2001. 
Pelzer, A.N., ed. Verwoerd Speaks: Speeches 1948-1966. Johannesburg: APB Publishers, 1966.

Ramírez-Barat, Clara and Roger Duthie. Education and Transitional Justice: Opportunities and Challenges for Peacebuilding. New York: ICTJ and UNICEF, 2015.

Robins, Simon. “Towards Victim-Centred Transitional Justice: Understanding the Needs of Families of the Disappeared in Postconflict Nepal." International Journal of Transitional Justice 5 (2011): 75-98.

Schaffer, Kay. "Memory Work and Memorialisation in the New South Africa." In Memory, Narrative and Forgiveness: Perspectives on the Unfinished Journeys of the Past, edited by Pumla Gobodo-Madikizela and Chris Van Der Merwe. Cambridge: Cambridge Scholars Publishing, 2009.

Sishuba, Yanelisa, Sindiswa Nunu, Nompumelelo Njana, Agnes Ngxukuma, Brian Mphahlele, and Jasmina Brankovic. Conducting Participatory Action Research with Apartheid Survivors: Lessons from "Addressing Socioeconomic Drivers of Violence in Khulumani Communities." Cape Town: Khulumani Support Group Western Cape and Centre for the Study of Violence and Reconciliation, 2017.

Sizemore-Barber, April. "Stages of Complicity, Stages of Healing: A Look at Two Theatrical Responses to South Africa's Truth and Reconciliation Commission." In Memory, Narrative and Forgiveness: Perspectives on the Unfinished Journeys of the Past, edited by Pumla Gobodo-Madikizela and Chris Van Der Merwe. Cambridge: Cambridge Scholars Publishing, 2009.

Tibbitts, Felisa and Peter G. Kirchschlaeger. "Perspectives of Research on Human Rights Education." Journal of Human Rights Education 2, no. 1 (2010): 8-29.

Vally, Salim. "From People's Education to Neo-Liberalism in South Africa." Review of African Political Economy 34 (2007): 39-56.

Wilson, Richard. The Politics of Truth and Reconciliation in South Africa: Legitimizing the Post-Apartheid State. Cambridge: Cambridge University Press, 2001. 
Open-Access-Publikation im Sinne der CC-Lizenz BY 4.0

(c) 2018, V\&R unipress $\mathrm{GmbH}$, Göttingen 


\section{At the Frontlines of Education and Peace: Arts-based Storytelling in the Classroom}

The discourse around the role of education in peacebuilding contexts is becoming rich in theory and practical recommendations, ${ }^{1}$ but what still remains under-examined is the experience of educators in teaching transitional justice, new history and/or peace-oriented curricula in divided societies. It requires strength and a modicum of bravery to openly grapple with identity and history in these contexts and the impact of such pedagogy has reverberations for generations to come. Given that most educators in places of transition have their own narratives of repression and/or conflict-related experiences, teaching these topics is even more fraught. This holds true in most transitional justice contexts where legacies of oppression, political violence, and war have reached across generations. Confronting these narratives in the classroom, perhaps for the very first time, is a difficult and even traumatic endeavor particularly when educators themselves have no outlet to process their own histories, perspectives, and biases as well as those expressed by students. The implications of this are vast and speak to the need for creative and safe spaces for educators in countries dealing with their pasts to give voice to the challenges they face as they seek strategies to overcome them.

Arts-based forms for storytelling, including what is known as participatory theatre, can be useful tools for teaching transitional justice, history, and peace given that these forms are a potentially useful means for addressing the need for self-articulated, personal, and shared narratives, opening up a space in which

1 See, for example, Education Committee Forum, Education and Social Cohesion: Education Strategies for Social Cohesion and Democratic Security (Strasbourg: Council of Europe, 2000); Elizabeth A. Cole, ed., Teaching the Violent Past: History Education and Reconciliation (Lanham, MD: Rowman \& Littlefield, 2007); Alan Smith, "The Influence of Education on Conflict and Peace Building," background paper for the Education for All Global Monitoring Report 2011: The Hidden Crisis: Armed Conflict and Education; and Clara Ramírez-Barat and Roger Duthie, Education and Transitional Justice: Opportunities and Challenges for Peacebuilding (New York: ICTJ/UNICEF, 2015). The author wishes to express deep thanks to Michelle O'Connor-Hill, Brisa Areli Muñoz, and Lili Nikolova for their critical input on earlier versions of this chapter. 
people can collectively share their stories and create "meaning about what happened in the community." This can serve as an important step not only toward individual healing and understanding, but also more broadly toward restoring collective memory and repairing the social fabric in which individuals are embedded. ${ }^{3}$ In highlighting points of connection and creating a more fluid understanding, such processes can break "crude" forms of cohesion among groups, allowing for the integration of other experiences across previously codified narratives and beliefs. ${ }^{4}$ Because of this, they could also help establish a creative space for educators to explore how their personal experiences of war and violence affect their perceptions of history. This is critical in ensuring that teachers are not only willing but also able to teach difficult topics and feel they have the support to do so in a manner that fosters dialogue and reflection, often in opposition to the views students receive at home and in wider society. These techniques could additionally serve as ways to support one another and develop strategies for stronger classroom engagement. Establishing a space for greater self-awareness as well as awareness of others can further help to bolster social cohesion by modeling "how to live in harmony in an environment which respects freedom of thought and conscience, encourages [individuals] to open up to others and develop a critical mind, while providing adequate support to those who need it." ${ }^{5}$ In other words, such a creative space allows for a better understanding of how to live as part of a community, how to acquire the values underpinning a democratic society, and how to achieve a better quality of life. ${ }^{6}$ These objectives are also aims of transitional justice.

This chapter ${ }^{7}$ is an attempt to both understand how arts-based storytelling methodologies can be used in educational settings to help teach transitional

2 Beatrice Pouligny, "Understanding Situations of Post-Mass Crime by Mobilizing Different Forms of Cultural Endeavors," (panel contribution, Nineteenth International Political Science Association World Congress, Durban, South Africa, July 1, 2003).

3 Stephanie Stepakoff, "Telling and Showing: Witnesses Represent Sierra Leone's War Atrocities in Court and on Stage," Drama Review 52, no. 1 (2008): 17.

4 Andrew Norton and Arjan de Haan, "Social Cohesion: Theoretical Debates and Practical Applications with Respect to Jobs," background paper, World Development Report 2013 (Washington, D.C.: World Bank, 2013), 4.

5 Nils Muižnieks, "Inclusive Education Vital for Social Cohesion in Diverse Societies," The Commissioner's Human Rights Comment, 5 May, 2015, http://www.coe.int/en/web/commis sioner/-/inclusive-education-vital-for-social-cohesion-in-diverse-societies, accessed $1 \mathrm{Fe}-$ bruary 2018.

6 Education Committee Forum, Education and Social Cohesion, 14.

7 Some of the material contained here also appears in a different form in Nadia Siddiqui, Hadi Marifat, and Sari Kouvo, "Culture, Theatre and Justice: Examples from Afghanistan," in The Arts of Transitional Justice: Culture, Activism and Memory after Atrocity, edited by Olivera Simic and Peter D. Rush. Springer Series in Transitional Justice 6 (New York: Springer Science + Business Media, 2014), 113-34. 
justice and to explore how these same methodologies can establish creative spaces of support to educators who are expected to teach this topic in difficult and divided settings. I will do this by first explaining the links between the act of storytelling, education, and transitional justice broadly, before more specifically presenting storytelling and performative processes used in formal and informal education settings in Lebanon, Afghanistan, and Iraq, and then analyzing the role of educators in these processes and the toll this work takes on them. Subsequently, I will examine examples of creative spaces for support developed for educators and others in "helping" professions, including Iraqi professors, Israeli and Palestinian community leaders, and American social workers as well as recommendations for taking this practice forward in other transitional justice settings and divided communities.

\section{Art, Culture, and Transitional Justice}

Catastrophes can pull societies apart, and they can also shatter the ordinary divides and patterns that separate people. In these circumstances, new communities can emerge, where people find purposefulness and connectedness in coming together amid death, chaos, fear, and loss. ${ }^{8}$ Rebecca Solnit argues that, in the aftermath of disaster, be it a hurricane or a bombing, the demolished status quo can create a space "in which we are who we hope to be, do the work we desire, and are each our sister's and brother's keeper." In contexts of prolonged conflict and/or repression in particular, however, as abuses and violence compound, survivors often find that their experiences are open-ended; they live with an event that "has no ending ... no closure and therefore ... continues into the present." 10 Performative arts and storytelling in conflict and transitional or peacebuilding settings can, for some at least, build a bridge to "whom we hope to be" by engaging with what has been termed the "moral imagination." This term refers to the capacity of individuals to stay grounded in the troubles of the real world while simultaneously remaining open to the possibilities of a better one. ${ }^{11}$

In these contexts, theatre and storytelling methodologies in particular can

8 Rebecca Solnit, A Paradise Built in Hell: The Extraordinary Communities that Arise in Disaster (New York: Penguin Books, 2009), 3.

9 Ibid.

10 Shoshana Feldman and Dori Laub, Testimony: Crisis of Witnessing in Literature, Psychoanalysis, and History (New York: Routledge, 1992), 62.

11 John Paul Lederach, The Moral Imagination: The Art and Soul of Building Peace (New York: Oxford University Press, 2005), 29; Cynthia E. Cohen, Roberto Gutierrez Varea, and Polly O. Walker, eds., Acting Together: Performance and the Creative Transformation of Conflict, vol.1, Resistance and Reconciliation in Regions of Violence (Oakland, CA: New Village Press, 2011), 11. 
play an important role when geared towards giving a voice to the marginalized while also demanding the right to speak publicly without fear. ${ }^{12}$ These forms of expression encourage understanding of the present and potential for future change by making relationships central and acknowledging interdependence among people and societies; cultivating paradoxical curiosity through inquiry about identities, values, and beliefs leading to understanding that is above simple dualities; making space for the creative act in contexts where political violence would make it seem that there are no options for cultural action and response; and finally, enabling risk-taking to allow people to examine possibilities of what a peaceful society could look like. ${ }^{13}$ In short, these practices can help in addressing the outer social world, the inner psychological world, and the transitional zone between the two within individuals and communities, which are crucial elements to post-conflict and/or repression reconstruction.

Having people actively participate in such a transformation process is a central principle not only of transitional justice but of community-based theatre as well. When explicitly crafted, participatory theatre exercises and games can offer participants an aesthetic instrument with which to analyze their past in the context of the present, without having solutions imposed on them by postconflict workers and experts. ${ }^{14}$ The underlying assumption of these methodologies is that all people are equipped to be actors and to take center stage. The main theatrical focus is on dialogue, which in these contexts (as well as in nonviolent conflict settings) has the explicit aim of allowing participants to take control of situations rather than simply having things happen to them.

Community-based theatre is most closely identified with Brazilian theatre director Augusto Boal and his Theatre of the Oppressed. For Boal, many ordinary citizens feel powerless in their daily lives and are, in fact, blocked in the face of oppression and injustice. To address this, he developed the Theatre of the Oppressed process whereby audience members, so-called spect-actors, can interrupt a performance and come onstage to change the dramatic action, propose various solutions, discuss plans for change, and train themselves for social action, taking on a "protagonistic function in the theatre and in society." 15 Through these processes, the theatrical act itself becomes a conscious intervention and a

12 Jonothan Neelands, "Acting Together: Ensemble as Democratic Process in Art and Life," Research in Drama Education: The Journal of Applied Theatre and Performance 14, no. 2 (2009): 180.

13 Cohen et al., Acting Together, 11-12.

14 United Nations Assistance Mission in Afghanistan (UNAMA), "Tears into Energy: Community-based Theatre and Transitional Justice," unpublished report, April 2008.

15 Ibid. See also Augusto Boal, Theatre of the Oppressed, trans. Charles A. Leal McBride, MariaOdilia Leal McBride, and Emily Fryer (London: Pluto Press, 2008), 95. 
rehearsal for social action based on spect-actors' collective analysis of a given conflict, its causes, and its possible resolution. ${ }^{16}$

Among the main components of Boal's approach are (1) Image Theatre, a basis for other participatory theatre work that asks participants to transform their own or others' bodies into representations of particular situations, emotions, or ideas; and (2) Forum Theatre, which allows audience members to stop a scene showing a conflict that the characters do not know how to resolve or transform, and suggest and try out possible solutions. In this context, "joker" characters serve as neutral moderators between the actors and the spect-actors, setting up the rules of the event for the audience, facilitating the spect-actors' replacement of the protagonist on stage, and summing up the essence of each proposed solution in the intervention. ${ }^{17}$

Storytelling methodologies and exercises also require a neutral moderator and can be used either in tandem with Theatre of the Oppressed approaches or on their own. One of the most prominent techniques is the so-called "story circle" in which participants sit unencumbered in a circle and, within a specific period of time, each tells a personal story around a given theme. The role of the other participants is to listen intently to what is being said. Once each individual has shared his or her narrative, participants can engage in cross-talk or dialogue about what they have just heard. They may ask clarifying questions or generate themes connecting these experiences. ${ }^{18}$ The importance of these techniques lies in the way in which they empower individuals as "personal stories position even the least powerful individual in the subject position, the I, since everyone is an expert on his or her own life." ${ }^{19}$ At the same time, they allow participants to identify and explore patterns relating to an experience, problem, or issue and find common threads of experience, building deeper relationships by illuminating these connections. ${ }^{20}$

Taken together, participatory theatre and storytelling exercises can help develop a creative space "in which people feel safe enough to take risks and to allow themselves and others to experience vulnerability." ${ }^{21}$ This space and these processes can present stories about specific communities or groups, whether or

16 Singhal, "Empowering the Oppressed," 146.

17 The term itself derives from the joker or wild card in a deck of playing cards, where that card is not tied to a specific suit or value. Similarly, the Theatre of the Oppressed joker has no allegiance to any one performer, spect-actor, or interpretation of events. Ibid., 148.

18 Research Center for Leadership Action, Story Circle Method, Practice Note (New York: Wagner School, New York University, 2008), 2.

19 Jan Cohen-Cruz, Local Acts: Community Based Performance in the United States (New Brunswick, NJ: Rutgers University Press, 2005), 139.

20 Research Center for Leadership Action, Story Circle Method, 1.

21 Helen Nicholson, Applied Drama: The Gift of Theatre (New York: Palgrave Macmillan, 2005), 129. 
not they are emerging from violent conflict and/or repression or dealing with other more ordinary tensions, laying the groundwork for bonding and interactivity within the community. ${ }^{22}$ This is important in bringing divided communities together and in helping to activate what William Ury terms the "third side," the surrounding community within a conflict which can serve as a container for escalating violence. ${ }^{23}$ Without it, "serious conflict ... all too easily turns into destructive strife. Within the container, however, conflict can gradually be transformed from confrontation into cooperation." 24

\section{Participatory Theatre and Storytelling in Education}

Arts practices used within transitional contexts can help promote empathy, moral development, connectedness, social agency, and critical thinking, ${ }^{25}$ and it is the potential for conveying these skills that connects them to educational practices and approaches in these environments. In societies that have experienced violent conflict and/or repression, education plays a fundamental role in the longer-term development of the post-conflict and/or repression context, to the extent that it can help successive generations understand the violence that took place - or continues to take place - within their own society. How this past and present is portrayed can also potentially contribute to the success or failure of future peacebuilding. Two aspects of this portrayal are (1) the teaching of history and (2) the unpacking of the concepts of truth and reconciliation. Setting aside the ethical and theoretical debates on teaching these topics in such contexts, ${ }^{26}$ the fact remains that it is common in affected countries to point to a role for education in promoting longer-term reconciliation as a means of preventing the recurrence of violence. This underlines the fact that peace is often tentative, relapses into violence are frequent, and that the main purpose of educational interventions at any stage in such a cycle is to promote a peacebuilding trajectory. ${ }^{27}$

22 Rustom Bharucha, "Between Truth and Reconciliation: Experiments in Theatre and Public Culture," Economic and Political Weekly 36, no. 39 (2001): 3767.

23 William Ury, The Third Side: Why We Fight and How We Can Stop (New York: Penguin Books, 1999), 7.

24 Ibid.

25 Cohen et al., Acting Together, 11.

26 These include but are not limited to debates around whose version of history is taught; whether truth is objective, subjective, or inter-subjective and whether people are more interested in establishing truth to seek justice rather than reconciliation; if it is possible to have reconciliation without justice; and whether reconciliation needs to be reciprocal. See Smith, "The Influence of Education on Conflict and Peace Building," 2-3.

27 Ibid. 
Often, "what" is being taught may be a point of contention, and curriculum reform and textbook development may be weighed down by a lack of political will, competing political narratives of events, or limited resources in post-conflict societies. Nonetheless, the way in which history and related topics are taught - that is, the "how" - can and should be prioritized to emphasize students' critical thinking skills and expose them to multiple historical narratives helping to reinforce democratic and peaceful tendencies in societies emerging from conflict and/or repression. ${ }^{28}$ Indeed, in the absence of will or resources, helping educators promote critical inquiry among students, through a variety of pedagogical means, may be more urgent or more impactful than reforming the curriculum. ${ }^{29}$ This is, however, much easier said than done, particularly in contexts where educators themselves have experienced violence or repression and where external societal factors and internal family dynamics further influence students' thinking and behavior. The burden for educators, then, already high in ensuring students meet specific learning objectives, increases with this role, both materially and psychologically.

Both factors certainly seem to be the case in Lebanon, Afghanistan, and Iraq, where participatory theatre and storytelling techniques have been used to start examining narratives of conflict. This has been initiated despite the lack of official curricula on the history of conflict, transitional justice, and peace in these respective contexts, and formal and informal educators alike report of the negative impact of this work on their own well-being. Each context will now be discussed in turn, followed by greater reflection on the impact this work has on educators and practitioners, and finally, on the presentation of methods for creating safe and creative spaces for educators in this regard using examples from the field.

\section{Creative Formal and Informal Curricula in Lebanon, Afghanistan, and Iraq}

A consortium of NGOs in Lebanon launched the oral history project Badna Naaref (We Want to Know), in 2011. While not the first program focused on youth, education, and the war in Lebanon, it was the first time a project en-

28 Dylan Wray, “The Past is Passed Down: An Introduction to the South African History Teacher Professional Development Programme, Facing the Past - Transforming Our Future," in Transitional Justice and Education: Learning Peace, edited by Clara Ramírez-Barat and Roger Duthie (New York: Social Science Research Council, 2017).

29 Elizabeth A. Cole and Judy Barsalou, "Unite or Divide? The Challenges of Teaching History in Societies Emerging from Violent Conflict," Special Report 163 (Washington, D.C.: United States Institute for Peace, 2006), 10. 
couraged young people to talk to their elders directly about the war. In this sense it helped to create an inter-generational dialogue between those who experienced the war and its impact directly and those who live with its consequences but who have little to no comprehension of the connection between how they live today and the broader legacy of conflict and its violence. ${ }^{30}$ High schools across the country were approached to provide input for the project in terms of its aims and methods, and also to participate. In total, 44 second-year high school students from 12 schools participated in the project under the supervision of their teachers. Students and teachers alike were trained in oral history and storytelling techniques. By the end of the project, 150 narratives were audio-recorded by students, capturing the daily experiences of people living in Lebanon during the war. These narratives are presented in Arabic, French, and English on a website launched at the end of the project with a party in south Beirut in April 2012. ${ }^{31}$

In the presence of religious and political figures, the media, and their families, several students gave speeches about their experiences interviewing family members and learning about their lives during the war. In so doing, a "safe" zone was established where students who would not normally interact given sectarian divisions were able to meet in person and swap stories. The launch event itself was therefore designed to build on the core purpose of the overall project: to demystify the "other," to share common experiences with fellow citizens, and to build relationships across borders so that young people in the country are less inclined to sectarian violence. ${ }^{32}$

Grappling with personal narratives to expose common themes that are relevant across communities, regions, and religions is also a key factor in the work of the Afghanistan Human Rights and Democracy Organization (AHRDO), Azdar Theatre/International Psychosocial Organization (IPSO), and International Relief \& Development (IRD) with theatre methodologies in Afghanistan and Iraq. While none of these organizations work in formal educational settings, they connect with people in marginalized communities and/or disputed territories using participatory theatre to create a space in which people come together to analyze the past in the context of the present. They thus initiate grassroots strategies for dealing with grievances, and become active protagonists in shaping a more peaceful and just society. ${ }^{33}$ In Afghanistan, for instance, the development

30 Lynn Maalouf and Christalla Yakintou, "Grappling with Lebanon's Enduring Violence: The Case of Badna Naaref, an Inter-Generational Oral History Project," in Transitional Justice, Education, and Peacebuilding, edited by Clara Ramirez-Barat and Roger Duthie (New York: Social Science Research Council, forthcoming).

31 See, http://www.badnanaaref.org/, accessed 1 February 2018.

32 Ibid.

33 Nadia Siddiqui, Hadi Marifat, and Sari Kouvo, "Culture, Theatre and Justice: Examples from Afghanistan," in The Arts of Transitional Justice: Culture, Activism and Memory after 
of two new theatre plays, Infinite Incompleteness (2010) and Heartbeat: the Silence after the Explosion (2014), by AHRDO and Azdar Theatre, respectively, sought to better connect the disparate stories of war victims and bring them to a wider audience in Afghanistan and abroad. The objective was to have these experiences and stories acknowledged as part of the culture of Afghanistan and be included as part of ongoing discussions for national stability. This work, while small in scale compared to the enormity of the legacies of conflict in these contexts, continues to provide openings for the discussion of history, transitional justice, and peace that challenge the prevailing political and societal status quo.

Despite - or because of - ongoing conflict, change seems to slowly be coming to Iraq in this regard, at least at university level. The University of Duhok has established its own Peace and Conflict Studies Program, and several professors from universities around the country have developed a draft curriculum for similar programs. Given the interest in teaching these topics, New York University and the University of Duhok undertook a cooperative capacity-building and exchange initiative, wherein Iraqi university professors were given training in peacebuilding instruction and practice. As part of this initiative, eight Iraqi professors from Duhok, Baghdad, and Kirkuk participated in training seminars in New York in 2011 on experiential, participatory theatre and storytelling techniques to use in their classrooms. Evaluation of the initiative indicated that the professors were willing to suspend their inhibitions in order to participate in new teaching methodologies. At the end of the seminar, a number of professors reported prioritizing the need for understanding and utilizing interdisciplinary methods within their own courses because such an approach would allow them to examine and teach peace and conflict studies from a new perspective. ${ }^{34}$ This further indicates not only that arts-based methodologies are useful approaches in history, transitional justice, and peacebuilding pedagogy in conflict-affected communities, but that appropriate pedagogical training is also necessary. Indeed, with the Badna Naaref project in Lebanon, educators identified a lack of resources and a feeling that, while there was a great deal of interest among their students to learn about Lebanon's recent past, they lacked the tools and skills to teach it. $^{35}$

Atrocity, edited by Olivera Simic and Peter D. Rush. Springer Series in Transitional Justice 6 (New York: Springer Science + Business Media, 2014), 125; and Ali Dahr (Iraq Program Director, IRD), in discussion with author, 27 March, 2014.

34 Rita Naman, "Monitoring and Evaluation Report for Building Capacity of Iraqi Academics in Peacebuilding Instruction and Practice," unpublished report, March 2012.

35 Maalouf and Yakintou, “Grappling with Lebanon's Enduring Violence." 


\section{The Role of Educators and the Toll of Teaching}

Appropriate training alone, however, is not enough to ensure educators have the resources - material and psychosocial - to teach history, transitional justice, and a peace-oriented curriculum in divided contexts. Training often underestimates and at worst overlooks the enormous pressure under which educators work. This pressure includes the expectation that they play multiple roles, from psychologist and guidance counselor to conflict resolution expert and mediator. ${ }^{36} \mathrm{Un}$ derlying this expectation is the assumption that educators are fundamental agents of social change even though evidence shows that many do not feel comfortable in this role and doubt that anything they teach can counter what history students learn at home. ${ }^{37}$ This may explain why a number of teachers refused to participate in the Badna Naaref project on the grounds either that the topic was too sensitive or that they did not see any merit in encouraging dialogue about the war. ${ }^{38}$ Those who are willing to broach these subjects do so whether in formal or informal educational settings, and face the risk of strong public criticism if not worse. One of Azdar Theatre's performances, for example, was the target of a suicide bomb attack in 2014. AHRDO staff have also had to endure abuse and derision when first entering a community because their approach entails introducing members of different groups to each other. This, coupled with the difficult personal narratives presented and their other nonperformancerelated duties within the organization, can take a physical and emotional toll. ${ }^{39}$ Ali Dahr, a Program Director for IRD in Iraq, also indicates that finding and keeping actors for the duration of program implementation is a difficult challenge with this type of work. ${ }^{40}$ In other words: "for these teachers ... what must it mean to have to relive the past every year? At what point does the telling become numbing and damaging and at what point does it present the possibility for healing?" 41

Left unchecked, these stressors and the experience of direct or vicarious trauma can lead to professional burnout rather than healing: emotional exhaustion or depletion of emotional resources; depersonalization manifested in detachment from the job and the people being served; and a reduced sense of personal accomplishment. ${ }^{42}$ These symptoms are problematic for educators in

36 Cole and Barsalou, "Unite or Divide," 11.

37 Ibid.

38 Maalouf and Yakintou, “Grappling with Lebanon's Enduring Violence.”

39 Siddiqui et al., "Culture, Theatre and Justice," 128.

40 Ali Dahr (Iraq Program Director, IRD), in discussion with author, 27 March, 2014.

41 Wray, "The Past is Passed Down."

42 Christina Maslach, Wilmar B. Schaufeli, and Michael P. Leiter, "Job Burnout," Annual Review of Psychology 52 (2001): 403. 
particular because they are the mediators of any curriculum and, even in a limited way, they impart values, model behavior, and play a role in socialization, whether they are aware of this role or not. ${ }^{43}$ In educational settings within transitional justice contexts, part of this socialization focuses on promoting value-laden, critically thinking, active, compassionate, and democratic citizenship and longer-term reconciliation. ${ }^{44}$ Given the intergenerational nature of violence ${ }^{45}$ in many of these contexts, if educators are not able to seriously engage with their pasts, share stories, hear from "the other," and think deeply about what their students might be hearing from them when they teach, it will be difficult for them to nurture the ethics needed for a livable future in their classrooms. ${ }^{46}$ This makes it even more imperative, then, that educators be able to explore their own experiences, perspectives, and biases in a self-reflective, nonjudgmental, community-oriented setting with their peers. ${ }^{47}$ Establishing this space with other educators can also help to prevent or reduce burnout and trauma because, while social support is important in general, the support of colleagues specifically seems to have a positive influence on both. ${ }^{48}$

The participatory theatre and storytelling training with Iraqi professors, while not used explicitly as a support space at the time, is one model in which arts-based methodologies have helped not only to foster camaraderie among educators - facilitators of the workshop noted how much fun everyone seemed to have with each other ${ }^{49}$ - but also allowed participants to explore difficult topics. In one story circle exercise, each participants had to listen as, one by one, individuals told a personal narrative around the theme of "home." Through this process, home was revealed as a place to which one will never be able to return and a place that is easily taken away. These ideas offer a small glimpse of the depth of experience with which these professors have to come to terms and not only facilitate classroom discussion and dialogue, but to assess how it impacts upon their own scholarship in peace and conflict studies.

With a space for this type of self-reflection, professional discussion, and play, educators may be able to unveil amongst themselves and their peers that which

43 Smith, "The Influence of Education on Conflict and Peace Building," 22.

44 Wray, "The Past is Passed Down."

45 Karen Murphy (International Director, Facing History and Ourselves), in discussion with author, 15 April, 2014.

46 Wray, "The Past is Passed Down."

47 Elizabeth A. Cole and Karen Murphy, "History Education Reform, Transitional Justice and the Transformation of Identities," Research Brief (New York: International Center for Transitional Justice, 2009), 4.

48 Christina Maslach and Julie Goldberg, "Prevention of Burnout: New Perspectives," Applied and Preventative Psychology 7 (1998), 72.

49 Leah Page Taisey (co-facilitator of participatory theatre and storytelling workshop with Iraqi professors), in discussion with author, 26 March, 2014. 
they "do not know now ... Whose stories, memories, and struggles might become visible?" ${ }^{50}$ And perhaps more importantly, they can help lay the bedrock in communities and classrooms on which the social trust needed for dealing with legacies of conflict must stand.

\section{Establishing A Creative Space: Examples from the Field}

A critical component in establishing a creative space for educators is bringing together individuals from different and/or opposed communities, particularly in divided societies. This is important because reconciliatory processes must reach beyond macro-level political processes and at some point "become part of people's lives, and also part of the midlevel and grassroots institutions, such as schools whose workings relate more closely to the lives of average citizens." ${ }^{\text {} 1}$ Having individuals from different communities or groups come together, much like the workshop described above for Iraqi professors, helps highlight the centrality of social/community relationships, curiosity, creativity, and risk in establishing a creative space not only for support but also for peacebuilding objectives. $^{52}$

An ideal setting for these exercises, then, would be one that neutralizes hostility, away from the space where conflict or stressors normally occur. As this setting is not owned or considered home turf by any of the people involved in the process, a power equilibrium occurs. ${ }^{53}$ The Outward Bound Peacebuilding's Emerging Leaders Program provides a useful example of this. The program seeks to contribute to a sustained shift in how Israeli and Palestinian leaders relate to each other, their own communities, and the Arab-Israeli conflict, and as such begins its work with a specific cohort with a catalyst ten-day, overseas, wilderness expedition. ${ }^{54}$

Because the daily context in which these leaders live and work is so fraught with tension, conflict, and seemingly codified identity politics, taking them out of this setting and into one that has less specific or no connotations of conflict for them allows a greater opportunity to engage as individuals rather than as fixed

50 Diana Taylor, The Archive and the Repertoire: Performing Cultural Memory in the Americas (Durham, NC: Duke University Press, 2003), xviii.

51 Elizabeth A. Cole, "Introduction: Reconciliation and History Education," in Teaching the Violent Past: History Education and Reconciliation (Lanham, MD: Rowman \& Littlefield, 2007), 14.

52 Lederach, The Moral Imagination, 34.

53 Lisa Schirch, Ritual and Symbol in Peacebuilding (Bloomfield, CT: Kumarian Press, 2005), 68.

54 Outward Bound Peacebuilding, Palestinian-Israeli Emerging Leaders Program (2008-2013), Flyer (New York: Outward Bound Center for Peacebuilding, 2013). 
opponents in an ongoing struggle. The use of a natural setting is also deliberate as research is increasingly establishing that being in a natural environment tends to relieve anxiety and stress and, in terms of peacebuilding, in engaging all human senses, adversaries tend to be more able and willing to recognize their shared humanity. ${ }^{55}$ Creating this kind of liminal space; that is, an in-between, set-aside context where the rules for acting and interpreting meaning are different from the rest of life, ${ }^{56}$ requires not only a specific physical space and a bringing together of people from different communities, but also symbolic objects, activities, and specific smells, tastes, and sounds. These help delineate the space created, both physically and emotionally, as a break from everyday routine or interaction.

Participatory theatre and storytelling exercises and practices can offer opportunities for participants to step outside their routines and, as a result, find new symbols, meaning, and connection for themselves and in relation to others. This held true for the child and family specialists from Appalachian Foster Care and Adoption Services, who participated in a two-day arts-based workshop in Tennessee in 2013. The workshop was designed to illuminate their assets as well as their interpersonal conflicts and concerns related to their work with traumatic and violent histories on a daily basis as they respond to the needs of some 400 vulnerable children and families on any given day in a rural, poverty-stricken, and isolated region of the United States. The structure of the workshop sessions, beginning with energizing and focusing activities which fed into larger theatre and storytelling procedures, and ending with reflection exercises, helped to create a set-aside transcendent space for connection and interaction. ${ }^{57}$

As one participant later recalled, "the moments of connection and communion were profound ones and I will carry them throughout my walk on this Earth." ${ }^{" 58}$ Another participant noted that this experience allowed her to move beyond her comfort zone, her regular behavior: "This is a big thing for me. I like my comfort zone. I don't like doing certain things. For me, to just get like this [on the floor] and do this, this is a big thing for me ... so this is good." 59 The embodied aspects of these performative approaches are also important. Stripped away of the language and rhetoric of difference and division, bodies in motion have the power to captivate and connect, engrained as they are with centuries of

55 Stephanie Westlund, “Incorporating 'the Earth and Skies, the Wind and Rocks:' Nature as an Active Participant in Conflict Transformation and Peacebuilding," Global Change, Peace \& Security 22, no. 3 (2010): 300-302.

56 Schirch, "Ritual and Symbol," 69.

57 Michelle O'Connor-Hill, "Celebrating Community: An Applied Theatre Workshop for Child and Family Specialists," Master's thesis, The City University of New York, June 5, 2013, 62.

58 Ibid., 60.

59 Ibid., 62. 
meaning in particular contexts that people in those contexts intrinsically understand. In using these methods with peace mediators to discuss support needs, the non-verbal aspects were found particularly important in creating such a liminal space, as one participant noted: "I would hope more people would dare to use body language ... it is much older than verbal language and is much faster and deeper." 60

The intensive, embodied, and immersive nature, then, of both the catalyst trip within Outward Bound Peacebuilding's Emerging Leaders Program and the workshop with child and family specialists allowed for participants in each group to gain a sense of trust and community with each other. This lays the groundwork for future and regular communication and support as each individual carries out his/her work in bringing their respective communities together. As one child and family specialist reported after the initial workshop, "I most definitely feel the strategies go beyond the workshop and impact community. Particularly the 'I Come From' activity: recognizing the complexities of my own experience and listening to those of others increased my awareness of our human connectedness ... it provides me with comfort when I remember our sharing circle and the ability to heal simply being present with one another." ${ }^{31}$ While acknowledging the power of such work, this statement also highlights the difficulties in sustaining these new perspectives without regular meaningful interaction with others and the space to do so when returning to daily life. ${ }^{62}$ This is particularly true when the ideas gained are at odds with those of the prevailing context and group to which one belongs.

In order to both address this and maintain connection and professional solidarity, the facilitators of this workshop created a private, password protected, Tumblr page ${ }^{63}$ on which participants could post sayings, narratives, and photographs. It is worth noting that while the Tumblr was set up in advance of the workshop, the bulk of the posts on the site appeared afterwards, suggesting participants continued to support one another. Similarly, participants of the Emerging Leaders Program created a Facebook group as a way to keep in touch and the program's curriculum provides for semi-regular shorter retreats via which to reconnect throughout the region. Utilizing participatory theatre and

60 Michelle O’Connor-Hill et al., "Creative Approaches for Support: Arts-Based Dialogue for Building Professional Support Amongst Mediators," interactive workshop facilitated at the $7^{\text {th }}$ Annual Mediators Beyond Borders International Congress (Bucharest, Romania, 23-26 April, 2015).

61 O'Connor-Hill, "Celebrating Community," 67.

62 See Ted Cantle, "What Works" in Community Social Cohesion (London: Department for Community and Local Government, 2007), 127; and George Allport, The Nature of Prejudice (Reading, MA: Addison-Wesley, 1954), 262.

63 Tumblr is a microblogging platform and social networking site. 
storytelling methodologies during initial immersion in both scenarios allowed for a relatively fast development of deep bonds within the groups. The sense of support and strength participants report gaining from these experiences prompted them to continue to build relationships online as well as through semiregular gatherings. This type of process could be adapted and replicated in contexts where educators are asked to push the bounds of not just what is taught regarding peace, justice, conflict and understanding history but also how it is taught. As these processes continue, bringing educators together to discuss their struggles and triumphs and understand their experiences can serve as a microcosm of the changes on which they are working at a broader level in their respective societies as a whole.

\section{Conclusion}

Context is important when considering how to broach transitional justice, history, and a peace-oriented curriculum in societies emerging from repression and/or conflict, particularly when that violence is motivated in part by identity. Participatory theatre and storytelling methods can be useful techniques for this purpose, to the extent that they "create space for discussion and can allow for local ownership of the process of remembering, taking into account its religious, ethical, cultural, social, and psychosocial dimensions by addressing individual and collective needs." ${ }^{\prime 4}$ Being able to grasp these complexities and multiplicities is critical in ensuring the positive effects of teaching the past by preventing renewed humiliation of one group or favoritism of another. ${ }^{65}$

This said, focusing solely on curriculum and pedagogy without taking into account the toll this work takes on educators, who themselves often have their own experiences of repression or violence, negates any kind of reform in this sector. Because educators are the medium through which any new curriculum or pedagogy is delivered to students, their ability to cope, process, and buy-in to the need to discuss sensitive topics is imperative to fostering longer-term transitional justice and peacebuilding aims within schools. Making room for educators to come together and establish a creative space in which to build relationships and discuss personal and professional experiences ahead of having to teach difficult topics to their students gives them the opportunity to understand and prepare, and thus improving their confidence in the pedagogy.

64 Ly Davaruth, "Notes of Pchum Ben," working paper, Recasting Reconciliation through Culture and the Arts, Coexistence International (Waltham/Boston: Brandeis University, 2005), 4.

65 Ramírez-Barat and Duthie, Education and Transitional Justice, 15. 
Participatory theatre and storytelling methodologies are useful both in the classroom and in building this space for educators. As one theatre practitioner states, "Through these methods we are able to move something in time. The aesthetic distance makes it powerful. Participants do not have to relive the trauma to tell the story." At the same time, these methods allow participants "to be able to look at the cube from different angles ... it is going to allow you to reexamine. Looking at the causes and effects helps [participants] discover new ways of moving through [trauma], pushing through it, and gaining a wider perspective." ${ }^{66}$ If educators are responsible for helping to shape the hearts and minds of subsequent generations of their societies - a task that itself is daunting in even the best of circumstances - it only follows that they not only be allowed but even encouraged to expand their own hearts and minds first.

\section{Bibliography}

Allport, George. The Nature of Prejudice. Reading, MA: Addison-Wesley, 1954.

Ames Key, Linda. Interview with author. Personal interview. New York City, 27 March, 2014.

Bharucha, Rustom. "Between Truth and Reconciliation: Experiments in Theatre and Public Culture.” Economic and Political Weekly 36, no. 39 (2001): 3763-3773.

Cantle, Ted. "What Works" in Community Social Cohesion. London: Department for Community and Local Government, 2007.

Cohen, Cynthia E., Roberto Gutierrez Varae, and Polly O. Walker, eds. "Acting Together: Performance and the Creative Transformation of Conflict." In Resistance and Reconciliation in Regions of Violence, vol. 1. Oakland, CA: New Village Press, 2011.

Cohen-Cruz, Jan. Local Acts: Community Based Performance in the United States. New Brunswick, NJ: Rutgers University Press, 2005.

Cole, Elizabeth A. "Introduction: Reconciliation and History Education." In Teaching the Violent Past: History Education and Reconciliation, edited by Elizabeth A. Cole. Lanham, MD: Rowman \& Littlefield, 2007, 1-22.

Cole, Elizabeth A. and Judy Barsalou. "Unite or Divide? The Challenges of Teaching History in Societies Emerging from Violent Conflict." Special Report 163. Washington, D.C.: United States Institute for Peace, 2006.

Cole, Elizabeth A. and Karen Murphy. "History Education Reform, Transitional Justice and the Transformation of Identities.” Research Brief. New York: International Center for Transitional Justice, 2009.

Dahr, Ali. Interview by author. Video call. 27 March 2014.

Davaruth, Ly. "Notes on Pchum Ben.” Working paper, Recasting Reconciliation through Culture and the Arts. Coexistence International. Waltham/Boston: Brandeis University, 2005.

66 Linda Ames Key (Education Director, Vital Theatre Company), in discussion with author, March 27, 2014. 
Education Committee Forum. Education and Social Cohesion: Education Strategies for Social Cohesion and Democratic Security. Strasbourg: Council of Europe, 2000.

Feldman, Shoshana and Dori Laub. Testimony: Crisis of Witnessing in Literature, Psychoanalysis, and History. New York: Routledge, 1992.

Lederach, John Paul. The Moral Imagination: The Art and Soul of Building Peace. New York: Oxford University Press, 2005.

Maalouf, Lynn and Christalla Yakintou. "Grappling with Lebanon's Enduring Violence: The Case of Badna Naaref, an Inter-Generational Oral History Project." In Transitional Justice, Education, and Peacebuilding, edited by Clara Ramirez-Barat and Roger Duthie. New York: Social Science Research Council, forthcoming.

Maslach, Christina and Julie Goldberg. "Prevention of Burnout: New Perspectives." Applied and Preventative Psychology 7 (1998): 63-74.

Maslach, Christina, Wilmar B. Schaufeli, and Michael P. Leiter. "Job Burnout." Annual Review of Psychology 52 (2001): 397-422.

Muižnieks Nils. "Inclusive Education Vital for Social Cohesion in Diverse Societies." The Commissioner's Human Rights Comment, 5 May, 2015, http://www.coe.int/en/web/ commissioner/-/inclusive-education-vital-for-social-cohesion-in-diverse-societies.

Murphy, Karen. Interview with author. Personal interview. New York City/Boston, 15 April, 2014.

Naman, Rita. "Monitoring and Evaluation Report for Building Capacity of Iraqi Academics in Peacebuilding Instruction and Practice." Unpublished report. March 2012.

Neelands, Jonothan. "Acting Together: Ensemble as Democratic Process in Art and Life." Research in Drama Education: The Journal of Applied Theatre and Performance 14, no. 2 (2009): 173-189.

Nicholson, Helen. Applied Drama: The Gift of Theatre (New York: Palgrave Macmillan, 2005).

Norton, Andrew and Arjan de Haan. "Social Cohesion: Theoretical Debates and Practical Applications with Respect to Jobs." Background paper. World Development Report 2013, Washington, D.C.: World Bank, 2013.

O'Connor-Hill, Michelle. "Celebrating Community: An Applied Theatre Workshop for Child and Family Specialists.” Master's thesis, The City University of New York. 5 June, 2013.

O’Connor-Hill, Michelle, Brisa Munoz, Lili Nikolova, and Nadia Siddiqui. “Creative Approaches for Support: Arts-Based Dialogue for Building Professional Support Amongst Mediators." Interactive workshop facilitated at the $7^{\text {th }}$ Annual Mediators Beyond Borders International Congress. Bucharest, Romania, 23-26 April 2015.

Outward Bound Peacebuilding. "Palestinian-Israeli Emerging Leaders Program (20082013).” Flyer. New York: Outward Bound Peacebuilding, 2013.

Ramírez-Barat Clara and Roger Duthie, Education and Transitional Justice: Opportunities and Challenges for Peacebuilding. New York: International Center for Transitional Justice/UNICEF, 2015.

Research Center for Leadership Action. "Story Circle Method." Practice Note. New York: Wagner School, New York University, 2008.

Schirch, Lisa. Ritual and Symbol in Peacebuilding. Bloomfield, CT: Kumarian Press, 2005. Siddiqui, Nadia, Hadi Marifat, and Sari Kouvo. "Culture, Theatre and Justice: Examples from Afghanistan." In The Arts of Transitional Justice: Culture, Activism and Memory 
after Atrocity, edited by Olivera Simic and Peter D. Rush. Springer Series in Transitional Justice 6. New York: Springer Science + Business Media, 2014, 113-134.

Singhal, Arvind. "Empowering the Oppressed through Participatory Theatre." Investigacion y Desarrollo 12, no. 1 (2004): 138-163.

Smith, Alan. "The Influence of Education on Conflict and Peace Building." Background paper for the Education for All Global Monitoring Report 2011: The Hidden Crisis: Armed Conflict and Education.

Solnit, Rebecca. A Paradise Built in Hell: The Extraordinary Communities that Arise in Disaster. New York: Penguin Books, 2009.

Stepakoff, Stephanie. “Telling and Sharing: Witnesses Represent Sierra Leone's War Atrocities in Court and on Stage." Drama Review 52, no. 1 (2008): 17-31.

Taisey, Leah Page. Personal interview with author. New York City, 26 March, 2014.

Taylor, Diana. The Archive and the Repertoire: Performing Cultural Memory in the Americas. Durham, NC: Duke University Press, 2003.

United Nations Assistance Mission in Afghanistan (UNAMA). "Tears into Energy: Community-Based Theatre and Transitional Justice.” Unpublished report. April 2008.

Ury, William. The Third Side: Why We Fight and How We Can Stop. New York: Penguin Books, 1999.

Westlund, Stephanie. "Incorporating 'the Earth and Skies, the Wind and Rocks': Nature as an Active Participant in Conflict Transformation and Peacebuilding." Global Change, Peace \& Security 22, no. 3 (2010): 297-313.

Wray Dylan. "The Past is Passed Down: An Introduction to the South African History Teacher Professional Development Programme, Facing the Past - Transforming Our Future." In Transitional Justice, Education, and Peacebuilding, edited by Clara Ramírez-Barat and Roger Duthie. New York: Social Science Research Council, forthcoming. 


\section{Building Bridges between Research and Education: The Institute for Historical Justice and Reconciliation}

\section{Introduction}

History is not a static record of the past but a force that shapes the present and future. Nowhere is this truer than for some of the most intractable conflicts of the modern world. Many communities, if not all, have histories of resentment and opposing interpretations of their past that can sometimes reach back centuries. Efforts to replace violence and hatred with dialogue and reconciliation are often unsustainable without addressing deeply complex legacies beneath the surface of conflict. Whereas most peacebuilding concepts put aside the past as a source for renewed conflict, reconciliation dedicates prominent if contested space to dealing with a divisive past in order to achieve a common future. ${ }^{1}$ It is here that the Institute for Historical Justice and Reconciliation (IHJR) does its work. ${ }^{2}$ The IHJR is committed to promoting reconciliation by directly tackling the historical roots of conflicts in divided societies through its innovative shared-narrative approach. In 2004, historians Elazar Barkan and Timothy Ryback established the IHJR as a project of the Salzburg Global Seminar. ${ }^{3}$ The IHJR is an independent, non-political and non-religious facilitator of projects targeting scholars, educators, and young people. Reaching out to younger generations in divided communities through historical research and education, the IHJR translates the abstract into the concrete, enabling its academic work to have a social impact. Changing youth perspectives on contentious history holds the key to finally

1 B. Tint, "History, Memory, and Intractable Conflict," Conflict Resolution Quarterly 27, no. 3 (2010): 247-248.

2 The IHJR began as a project at the Salzburg Global Seminar, moved to The Hague, and is now a project of the European Association for History Educators (EUROCLIO). For more information on its ongoing activities, see http://historyandreconciliation.org/.

3 "The Salzburg Global Seminar is a foundation originally created in 1947 to encourage the revival of intellectual dialogue in postwar Europe. Today it designs, facilitates, and hosts international strategic convening and multi-year programs to tackle systems challenges critical for the next generation in the areas of imagination, sustainability, and justice." See more at http://www.salzburgglobal.org/. 
breaking cycles of conflict and hatred in order to deliver sustainable peace. This chapter will explain IHJR's efforts to bridge the academic work of committed historians into projects that have relevance to society, and more precisely to young people. ${ }^{4}$ We will argue that its pioneering approach to using historical research projects has significantly contributed to developing its shared-narrative approach as an enabler in historical reconciliation. ${ }^{5}$

The shared-narrative approach can be considered an increasingly important part of the non-judicial set of instruments available within the field of transitional justice. ${ }^{6}$ Using history to allow a society to come to terms with its abusive past has its roots in the role of dialogue on divisive history between adversaries, or what Ann Rigney calls "the mediated production of common memory narratives." In such a dialogue, adversaries, whether states or communities, are required to face a shared history of mutual violence, mediate between opposing perspectives, and to acknowledge their own role and guilt in order to develop empathy towards one another. Examples of this approach would include, for instance, historical commissions on France and Germany, Germany and Poland, or Germany and Israel. For the IHJR the challenge is twofold: at the academic level the challenge is to bring academics from opposing perspectives together to construct shared narratives, while, at the educational level, the challenge is to find ways in which a dialogue about a divisive past can become part of policy, curricula and informal mechanisms that aim to change "children's abilities and skills for participating in a country's productive and socio-political realms."

This chapter will further take stock of the more practical challenges that the IHJR faces in its work. It is, in part, a personal account of how the IHJR has transitioned slowly from a research-based organization into one of both scholarship and dissemination. We will discuss the IHJR's approach in three sections. Using its theory of change, the chapter will explore the meaning of the term "reconciliation" and the role historians can play in it, highlighting some of the academic debates regarding its approach. The two phases of IHJR intervention will be described: the research phase and the educational phase of its work; and

4 E. Cole, "Transitional Justice and the Reform of History Education," International Journal of Transitional Justice 1, no. 1 (2007): 115-137.

5 The authors would like to thank Clara Ramírez-Barat and Martina Schulze for their patience and helpful comments on previous drafts. Marie-Lousie Ryback also provided helpful input on earlier versions of this chapter.

6 C. Ramírez-Barat and R. Duthie, Education and Transitional Justice: Opportunities and Challenges for Peacebuilding (New York: ICTJ and UNICEF, 2015). For a recent discussion, see also the online debate organized by ICTJ in 2016, "Does Collective Remembrance of a Troubled Past Impede Reconciliation?” https://www.ictj.org/debate/remembrance/opening-remarks.

7 A. Rigney, “Reconciliation and Remembering: (How) does it work?” Memory Studies 5, no. 3 (2012): 251-52.

8 C. Ramírez-Barat and R. Duthie, Education and Transitional Justice, 1. 
finally, in the last section, we will focus on identifying the most significant challenges faced by the organization while accomplishing these tasks.

\section{The IHJR Approach}

The IHJR is a non-governmental organization aiming to promote reconciliation in societies divided by historical conflict and gross human rights violations by producing shared historical narratives. Between 2005 and 2013, it successfully completed seven projects pertaining to shared narratives in the contexts of five long-term conflicts. ${ }^{9}$ For this purpose, the Institute brought together some 100 scholars with different perspectives from Israel-Palestine, Armenia-Turkey, and the Balkans during the same period in order to draft seven unique, high-quality publications. To accompany the process, the IHJR partnered with, amongst others, the University of Leiden, Brandeis University, the European Association of History Educators (EUROCLIO), Physicians for Human Rights, the Arab Thought Forum, the Institute for the Study of Human Rights at Columbia University, the Ukrainian Jewish Encounter Initiative, the Salzburg Global Seminar, and the Scholar's Initiative. Support for these projects was received from a wide range of donors, both public and private, including the European Commission, the Dutch Foreign Ministry, the Adessium Foundation, the Sigrid Rausing Trust, the Ford Foundation, and the MacArthur Foundation.

The IHJR's working approach to interventions is based on its theory of change ${ }^{10}$ which is comprised of seven steps or benchmarks, including:

Step 1: Historians and experts from antagonistic communities are invited to come together to discuss the construction of a shared historical narrative.

Step 2: Historians and experts from antagonistic communities agree on the framework of a project to create an informed interpretation of a conflict.

Step 3: Historians and experts produce information that shows the shared historical narrative from all sides of the conflict that can be of use to teachers, educators, university professors, and those engaged with youth.

Step 4: Local actors, university professors, educators, and media disseminate at the national level the information produced about the shared narrative in order to create an awareness of the other's perspectives among youth.

Step 5: Young people become engaged in peacebuilding networks, using the work of the IHJR to confront and prevent the misuse of disputed historical legacies by local, regional, and national authorities.

9 IHJR, Internal Report (2013). Copy on file with authors.

10 H. Clark and D. Taplin, Theory of Change Basics: A Primer on Theory of Change (New York: Actknowledge, 2012). 
Step 6: Local, regional, and national governments translate the work of the IHJR into policies that support reconciliation.

Step 7: Reconciliation policies are implemented by local, regional, and national governments and support reconciliation among groups from antagonistic communities.

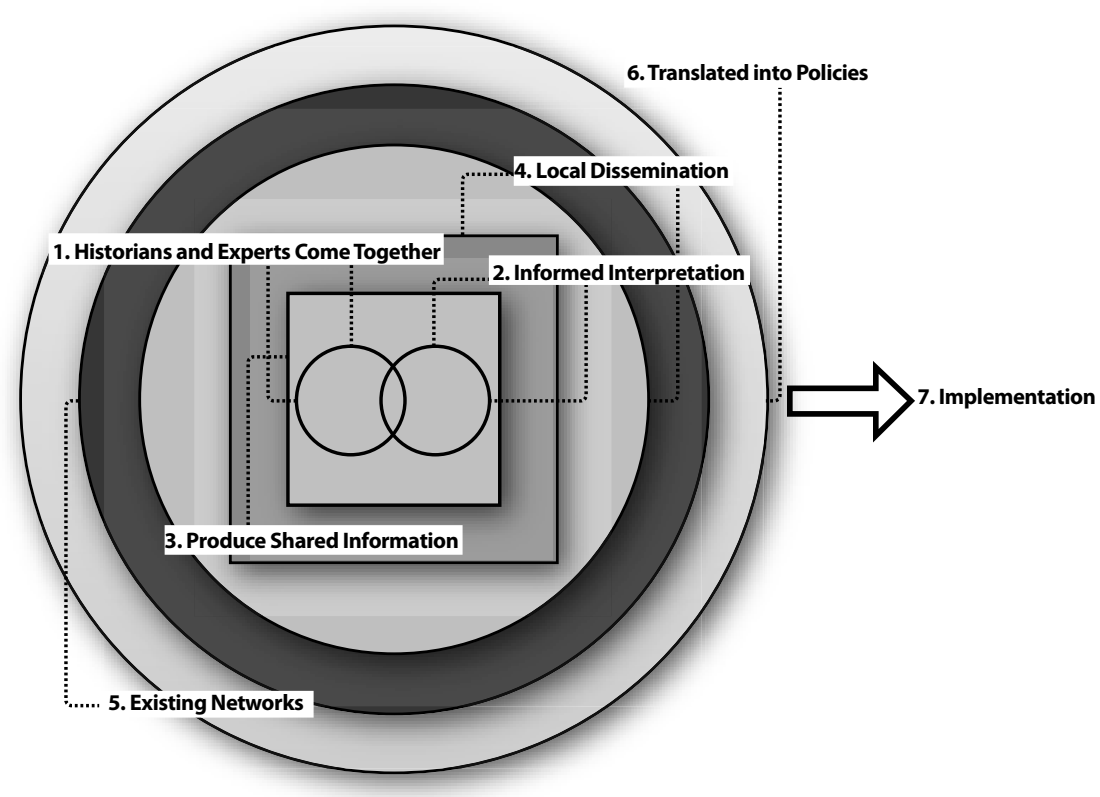

Fig. 1: Diagram of the IHJR's Theory of Change

In terms of process, the IHJR selects projects on historical issues that are highly sensitive and often still part of tense political and societal relationships. The Institute's non-partisan, academic approach to history appeals to groups and governments who disagree over historical facts, events, or perceptions of history at the root of a longstanding conflict. This has resulted in demands from different groups and stakeholders. In some cases, such as the Armenia-Turkey narrative, for example, the project was the indirect result of the rapprochement between the governments of Turkey and Armenia in 2008. In other cases, such as the IsraelPalestine project, the demands came from different actors, including civil-society coalitions and academics. ${ }^{11}$ In most projects, the political context is taken as an important or even crucial factor in deciding which topics to address. From there, the IHJR identifies a set of agreed historical benchmarks to be assessed and addressed by the participants in the project. In the words of Barkan and Ryback,

11 T. Ryback, “Enter the Historians, Finally," International Herald Tribune, 24 November 2006. 
"history is best when it is researched and debated before it is lobbied and legislated." 12

On balance, the IHJR has worked on conflicts in several different regions and on many areas of focus over the past few years, including a project on the narratives of the recent electoral violence in Kenya ${ }^{13}$ and a program on the Former Yugoslavia, aiming to counter xenophobic myths and prejudices in the region. ${ }^{14}$ In some cases, such as the Armenia-Turkey project, the proposal combined visual and cultural expression, with a photographic exhibition on the contested border region, a shared narrative on the construction of the railroad between Tbilisi and Kars, and a short documentary on the subject. ${ }^{15}$ Finally, and perhaps most importantly, the Institute has worked on historical reconciliation in Israel and Palestine. In four different research projects, the IHJR has successfully engaged Israeli and Palestinian historians in writing narratives about their region. ${ }^{16}$

\section{The Work of the IHJR and Academic Research on Dealing with the Past}

After a brief introduction to the IHJR's approach, this section develops the argument further by focusing on current debates surrounding the role of history as an enabler of reconciliation, a premise on which the IHJR focuses its work. ${ }^{17}$ The IHJR's theory of change relies on the role played by historians and experts in contributing to reconciliation. However, difficulties with terminology are abundant. What is the meaning of reconciliation? And in what ways can the historical profession with its emphasis on archival and source-based inquiry produce activist historians whose shared narratives can contribute substantially to conflict resolution? To further understand the role of history in reconciliation we will explore in more length some of the debates surrounding the term "reconciliation" and reflect on the debate among historians on their role as "reconciliation activists." In this section, we will look at some of the key concepts that feed into the IHJR's logic of intervention, beginning with the meaning of "reconciliation" in itself and subsequently exploring the difficulties and conceptual

12 E Barkan and T. Ryback, “A \$12 Billion History Lesson,” International Herald Tribune, 25 February 2008.

13 http://historyandreconciliation.org/our-work/projects/kenya/.

$14 \mathrm{http}: / /$ historyandreconciliation.org/our-work/projects/former-yugoslavia/.

15 http://historyandreconciliation.org/our-work/projects/armenia-turkey/.

16 http://historyandreconciliation.org/our-work/projects/israel-palestine/.

17 According to its statutes, the IHJR promotes "reconciliation in societies divided by historical conflict." 
challenges often experienced by historians when seeking to utilize their 'trade' to achieve social change.

\section{What is Reconciliation?}

The concept of reconciliation has become increasingly popular since the 1990s, and now often serves as one of the most popular buzzwords when dealing with the legacy of violent pasts. Yet despite its popularity, reconciliation remains an elusive term. Practitioners and academics alike acknowledge that the term is complex and often used in extremely different ways. "Reconciliation means different things to different people," writes Luc Huyse, "its significance varies from culture to culture, and changes with the passage of time."18 Archbishop Desmond Tutu - chairman of the South African Truth and Reconciliation Commission - reportedly said he had not met two people with the same definition of reconciliation. ${ }^{19}$ This lack of conceptual clarity is one of the greatest problems faced by both academics and practitioners working in the field.

In the work of the IHJR, the absence of a single, authoritative understanding of the term has resulted in a pragmatic attitude towards the concept of reconciliation. Indeed, despite many internal discussions, the IHJR does not offer a public working definition of the concept, opting instead for a vision and a theory of change that could lead to "reconciliation" - considering that the term can be interpreted on a case-to-case basis attending to the specific needs of different post-conflict situations. For the purposes of positioning the work of the IHJR in its efforts to promote reconciliation in countries divided by historical conflict, however, we would like to offer an additional explanation.

A recent practice-oriented handbook on the topic defines reconciliation simply as "a process through which a society moves from a divided past to a shared future." ${ }^{20}$ Moreover, according to other scholars, reconciliation could include "the rebuilding of fractured individual and communal relationships after conflict, with a view to encouraging meaningful interaction and cooperation between former antagonists ... the reshaping of parties' relationships, to lay the foundation for future engagement between them. ${ }^{21}$ Crocker's distinction be-

18 L. Huyse, "The Process of Reconciliation," in Reconciliation after Violent Conflict. A Handbook, edited by D. Bloomfield et al. (Stockholm: IDEA, 2003), 19.

19 See his No Future without Forgiveness (New York: Doubleday, 1999).

20 D. Bloomfield, "Reconciliation: an introduction," in Reconciliation after Violent Conflict, 12.

21 P. Clark, "Establishing a Conceptual Framework: Six Key Transitional Justice Themes," in After Genocide: Transitional Justice, Post-Conflict Reconstruction and Reconciliation in Rwanda and Beyond, edited by P. Clark and Z. K. Kaufman (London: Oxford University Press, 2008), 194. 
tween "thin" and "thick" forms of reconciliation has gained a certain authority within the field of peace and conflict studies. "Thin" reconciliation represents the absence of violence or "simple coexistence." The middle ground entails mutual respect and (democratic) dialogue, while "thick" reconciliation implies "reconciliation as forgiveness, mercy (rather than justice), a shared comprehensive vision, mutual healing, or harmony." 22 Drawing on Crocker's distinction, Borer further differentiates between what she calls "interpersonal/individual reconciliation" (IR) and "national unity and reconciliation" (NUR). IR deals with individual victims and perpetrators (or even the self after trauma) and is associated with the religious and therapeutic discourse of "thick reconciliation." NUR, by contrast, is located in the domain of statecraft and deals with political institutions. Inspired by the power politics of realism, NUR logic follows a "thin" reconciliation of coexistence and functioning democracy. ${ }^{23}$

The mission of the IHJR is to foster reconciliation between societies and communities; it thus follows the logic of both IR and NUR considering that, through the interpersonal connections between researchers, the process attempts to have a societal (intrastate) and perhaps even political impact on the perceptions of history between states. As an early visionary document of the IHJR states, "these events are frequently misunderstood and manipulated to serve partisan political ends, often serving public propaganda to fuel prejudice, hatred and destructive nationalist sentiments. The IHJR seeks to confront and overcome these ... laying the building blocks for peace and inter-communal reconciliation." ${ }^{24}$ Nevertheless, the mechanism through which the IHJR seeks to foster reconciliation is first and foremost the analysis of competing histories and understanding, thereby tending more toward "thick" versions of reconciliation.

\section{Historians and Activism on Historical Dialogue}

The perspective of the historian as an active agent of reconciliation needs to be considered in the context of the discipline of history. This section will discuss some of the arguments in favor of and against such involvement. In theory, the issue of societal engagement on the part of historians has been discussed within the profession ever since its inception as an academic discipline. The role of historiography in helping to create a better world and, to that end, occasionally

22 D. A. Crocker, "Reckoning with Past Wrongs: A Normative Framework," Ethics and International Affairs 13, no. 1 (1999): 60.

23 T. A. Borer, "Truth Telling as Peace-building Activity. A Theoretical Overview," in T.A. Borer, ed. Telling the Truths: Truth Telling and Peace Building in Post-Conflict Societies (Notre Dame: University of Notre Dame Press, 2006), 32-33.

24 IHJR Vision Document, 2009. Copy on file with authors. 
sacrificing its claim to (total) objectivity has been a difficult balancing act. Accordingly, many historians have been reluctant to risk their academic reputations by embarking upon projects that seek to promote reconciliation.

The question of the role that professional historians might play when addressing a violent, repressive past has flared up in the wake of post-conflict reconciliation and dealing with the past. ${ }^{25}$ For this reason, the IHJR has always tried to encourage historians to play an atypical activist role and view their contributions as providing constructive tools in reconciliation initiatives at the diplomatic and/or legal levels. According to the founders of the IHJR, Elazar Barkan and Timothy Ryback, history had for many years been the missing link in the field of conflict resolution. They asked historians to step outside their academic "comfort zone" and produce shared narratives that could contribute to the reconciliation process. Such was the context in which the IHJR was founded. ${ }^{26}$

The idea that historians could play an active role in fostering reconciliation in divided societies is seemingly winning some ground. Alexander Karn argues that from the mid-1990s onwards, there was an increasing interest in the capacity of professional historians to engage in the politics of the past and to help improve relations haunted by past injustices: "Scholars began to seriously contemplate the importance of confronting traumatic episodes from the past and accepting the moral obligations attached to historical injustice." ${ }^{27}$ As "activists" or "jurisprudential historians" they began to use history as a tool in mediation, taking part in historical commissions, joint history projects and various other projects all over the world. ${ }^{28}$ Examples of this include some initiatives such as the Scholars Initiative for the Western Balkans, the multiple joint history textbook com-

25 See also the online debate organized by the ICTJ: "Does a Collective Remembrance of a Troubled Past Impede Reconciliation?" at https://www.ictj.org/debate/remembrance/ope ning-remarks, accessed 12 January 2018.

26 It should be noted that we have focused here on the role of historians. The institute's theory of change uses the phrase "historians and experts" to reflect the more interdisciplinary outlook and the recognition of complementarity in fields such as social anthropology, political science and sociology.

27 A. M. Karn, "Depolarizing the Past: The Role of Historical Commissions in Conflict Mediation and Reconciliation," Journal of International Affairs 60, no. 1 (2006): 31.

28 See, for instance, K. V. Korostelina and S. Lässig, eds., History Education and Post-Conflict Reconciliation: Reconsidering Joint Textbook Projects (London and New York: Routledge, 2013). See also the Security Council open debate on "War, its Lessons and the Search for a Permanent Peace," which aimed to enable the Council to draw lessons from the understanding of war and to establish the requirements for a permanent peace. The debate was held in New York on 29 January, 2014 (more information at http://historyandreconciliation.org/ the-unsc-war-its-lessons-and-the-search-for-a-permanent-peace/), accessed 15 November 2017. 
missions that have been created in East Asia, or even the recently founded Finnish initiative Historians Without Borders. ${ }^{29}$

Many historians, however, would likely contest the need for such a role. ${ }^{30}$ Barkan acknowledges that his approach can cause what he has referred to as historiographical paradoxes: "advocacy and activism have traditionally been viewed as the polar opposites of dispassionate scholarship. Similarly, the study of history as the study of the past has been understood as distinct from an intentional activism aimed at influencing the future." ${ }^{31}$ While he acknowledges the challenges, he claims that these can be overcome by means of the professional methodology of historians, a classic argument of engaged scholarship: it is about "first-rate history" that also "explicitly contributes to political reconciliation." 32 Flanking the question of historical engagement is the question of impact. While joint history projects often have a symbolic impact - working together to overcome old hatreds - their results are often meagre. There is often a large gap between the ideal of a joint textbook commission and the difficult reality of transferring the shared accounts into a history education dictated by a nationalist agenda. Truth does not always lead to transformation; being confronted with authoritative data is no guarantee that attitudes will change, let alone identities. ${ }^{33}$

In fact, many authors are sceptical as to whether the search for historical truth and political change can ever be successfully combined. Can both be equally prioritized? Does one not automatically mean a compromise on the part of the other $?^{34}$ Tension between the professional ethics and emotional investment of historians is very likely to remain inherent to the history-based approach.

$29 \mathrm{http} / / /$ www.historianswithoutborders.fi/en/, accessed 15 November 2017.

30 N. Wouters, "The Use of History in the Field of Transitional Justice: A Critical Introduction," in N. Wouters ed., Transitional Justice and Memory in Europe (1945-2013) (Cambridge: Intersentia, 2014), 1-25, provides a solid introduction on the use (and abuse) of history in transitions and reconciliation processes, including the role of historians therein. See also K., Neumann, "Historians and the Yearning for Historical Justice," Rethinking History: The Journal of Theory and Practice 18, no. 2 (2014): 145-164. Classic texts on the role and (im)possibilities of historians regarding these matters: C. S. Maier, "Doing History, Doing Justice: The Narrative of the Historian and of the Truth Commission," in Truth v. Justice. The Morality of Truth Commissions, edited by R. I. Rotberg and D. Thompson (Princeton: Princeton University Press, 2000), 261-279; and C. S. Maier, "Overcoming the Past? Narrative and Negotiation, Remembering and Reparation: Issues at the Interface of History and the Law," in J. Torpey, ed., Politics and the Past. On Repairing Historical Injustices (Lanham: Rowman \& Littlefield Publishers, 2003), 295-305.

31 E. Barkan, "Introduction: Historians and Historical Reconciliation," The American Historical Review 114, no. 4 (2009): 906.

32 Barkan, "Introduction," 900.

33 Korostelina and Lässig, eds., History Education and Post-Conflict Reconciliation.

34 See B. Bevernage, "Transitional Justice and Historiography: Challenges, Dilemmas and Possibilities," Macquarie Law Journal 13 (2014): 7-24. 
Wouters concisely voices the dilemma at hand: "the risk of isolating the historic profession from important and acute societal developments seems real. At the same time, the risk of delegitimizing the historic profession by serving other interests is equally real." ${ }^{\prime 5}$ Historians of the IHJR have privately voiced similar concerns, and scholars participating in IHJR projects have echoed both positions. Adel Manna and Motti Golani, for example, in referring to their joint book project that resulted from an IHJR project in the Middle East, state in their introduction that: "Amongst other reasons, this book is unique in that we, the authors, are professional historians committted to the rules of academic research employed by research universities, but who also recognize contemporary narratives of the 1948 war as an influential force shaping the present and as a tool that can be used to shape the future." ${ }^{36}$

\section{The Research Challenge, Phase I (Steps 1 to 3 of the Theory of Change)}

The above discussion has highlighted several of the principal theoretical issues faced by the IHJR in its work. This section will focus on the IHJR's methodology and discuss the ways in which scholars in IHJR projects have typically constructed a shared narrative, corresponding to the first steps of the IHJR theory of change as indicated above. For each step we will try to highlight the primary elements and challenges to be overcome.

Following the IHJR theory of change, projects typically begin with a phase of historical research in which historians and experts from antagonistic communities come together to discuss and construct a shared, yet nonetheless contested, historical narrative. This process consists of three closely related steps. The first step generally focuses on the selection of participants, the establishment of the agenda and format of the meetings, and the framework of the dialogue with the aim of identifying the issues that might be included and the positions participating scholars might represent. In relation to the selection of the participants, the IHJR endeavors as far as possible to invite scholars of the highest reputation in the target countries to a meeting. These scholars are also expected to represent a perspective or background that might be identified as divisive. Often, they agree to participate on an individual basis without in-

35 Wouters, "The Use of History in the Field of Transitional Justice," 13.

36 M. Golani and A. Manna, Two Sides of the Coin: Two Narratives of the 1948 War and its Outcome (Dordrecht: Institute for Historical Justice and Reconciliation and Republic of Letters Publishing, 2011), 6. 
stitutional affiliation, due to the politically sensitive nature of the topics selected for the discussion. Representing an institution is often seen as too problematic.

The choice of location for these meetings is another point to consider. In principle, the IHJR aims to organize them in the country or region of the conflict in order to guarantee that the process of reconciliation is fully rooted in its geographical and political context. In some instances, however, the work has had to be done elsewhere. For example, in the case of the Israel-Palestine project, meetings that took place on neutral ground, such as The Hague, Salzburg (where the IHJR was initially based), or "third party territory," were instrumental in convincing scholars from both sides to agree to work together at all.

As a second step of the process, the IHJR moves from format to content: historians and experts from antagonistic communities collectively work to produce an informed interpretation of a conflict. Several meetings are organized in which scholars convene and discuss potential cases or historical benchmarks that can then be developed into a shared narrative. These are multi-level discussions that have political, academic, social and personal implications. At these meetings the IHJR typically acts as an independent facilitator, mediating between the diverging positions of scholars on historically tense issues. Scholars are asked to bring their concerns and priorities to the table; for example, in a recent project on the Western Balkans historians from several countries jointly authored a list of specific historical benchmarks that would be addressed by the project. Most discussions focus on the question as to which benchmarks directly address public myths, and what the subsequent outcome would be if researched. Subsequently, the researchers evaluate which dimensions might have the greatest social impact on the identified target audience.

In a third step, historians and experts produce information depicting the shared historical narrative from all sides of the conflict. In this phase, the production of the shared narrative implies that each of the historians needs to be committed to researching and writing a new unifying narrative. This could be a narrative that includes two opposing versions, or a joint narrative in which differences are recognized by both sides. In some cases, a controversial issue can be addressed by means of mediation efforts. For example, the IHJR decided in the case of the project on Israel-Palestine to focus on 1948, one of the most contested dates in terms of narrative (see box below). In other cases, such as the ArmeniaTurkey project, a more indirect approach was necessary in order to bring Armenian and Turkish scholars together. This is the reason why the ArmeniaTurkey research team opted to map the history of railway workers on the TbilisiAleksandropol-Kars Railway $1895-1899,{ }^{37}$ which focuses on the peaceful coex-

37 http://historyandreconciliation.org/resources/publications/the-construction-of-the-tiflisaleksandropol-kars-railway/, accessed 25 October 2017. 
istence between multiple communities while building a railway in the Ottoman Empire, as opposed to the much more controversial history of Armenians in Eastern and Western Anatolia in 1915.

\section{Case I. Institute for Historical Justice and Reconciliation: The Middle East Project ${ }^{38}$}

A powerful example of how the first three stages of the IHJR theory of change work is the Israel-Palestine project. This was prepared in 2004 and funded from October 2006 to April 2011. In 2005, there was strong willingness on both sides to work on peace and reconciliation. Initially conceived as a mapping project, it ultimately produced three shared narrative publications: one on the war of 1948 and its maps, another on refugee issues related to 1948 , and a final shared narrative on sacred sites in Jerusalem. In a separate process, the IHJR produced a shared narrative on Haifa, explaining its many spaces of cultural interaction and co-existence.

The publication Two Sides of the Coin: Independence and Nakba is particularly illustrative of how important the first step of the theory of change can be. The IHJR asked two of the lead historians of this joint endeavor, Adel Manna and Motti Golani, to describe the events of 1948, referred to as the "Nakba" (catastrophe) by Palestinians and "Independence" by Israelis, in one narrative. In some cases, the project teams had to convene in other countries such as France, Austria or the Netherlands in order to continue their work.

The second step of the theory of change is perhaps the most visible in all of the IHJR projects. Historians have an informed interpretation of a specific conflict. Appreciation of other researchers' perspectives is therefore crucial. Adel Manna and Motti Golani have become champions of the approach and frequently share with third parties the beneficial impact of working together on two completely opposed narratives of the events of 1948 . They frequently lecture on how this has impacted their work on an individual level.

The third step is particularly well exemplified by the work of Motti Golani and Adel Manna. Instead of writing separate chapters, they were asked to write all the chapters together. They were thus able to construct a best practice approach, and their joint endeavor resulted in a shared historical narrative. Every sentence had to be a form of consensus between the authors; to recognize the grievances and perspectives of the other, despite tense debates, and is one of the rare attempts to present one unified narrative of 1948 to the public sphere. Such a unified narrative approach is most challenging to achieve in many respects; in this case, for instance, the publications did not integrate both Hebrew and Arab script, instead, separate Hebrew and Arabic versions had to be developed for each of the shared narratives.

Having examined the substantive side of establishing a joint narrative, it is also necessary to consider some of the practical challenges to be faced when publishing the results of a shared-narrative project. During the publication phase,

38 See, http://historyandreconciliation.org/our-work/projects/israel-palestine/, accessed 15 September 2017. 
the IHJR decides on the design of a book in consultation with the project participants, and whether it may or may not include multiple translations on one cover. For example, the publications from the Israel-Palestine project received separate Arabic-English and Hebrew-English editions. This was due in part to the political sensitivities of target audiences and in part to the difficulties involved in finding a publisher willing to include Hebrew, Arabic, and English script in one volume. In the experience of the IHJR, the shared-narrative approach typically does not mean a "one size fits all" publication, but rather one that must overcome several editorial and linguistic barriers. One publication from the Israel-Palestine project, ${ }^{39}$ for example, was produced in English only, whereas others were published in separate Hebrew and Arabic editions. In some cases, the IHJR succeeded in creating a unified shared narrative whereas in other publications professors from both sides preferred to write from their own perspective with the result that both stories could be presented in parallel.

At least seven separate publications have resulted from the work of the IHJR, including a publication on internally displaced peoples in Kenya, ${ }^{40}$ four publications on Israel and Palestine, ${ }^{41}$ one on Armenia and Turkey, ${ }^{42}$ and finally a separate publication on political myths in the former Yugoslavia, ${ }^{43}$ all of which may be considered projects seeking a shared narrative. In these endeavors, historians with contrasting and sometimes opposing perspectives successfully managed to jointly draft a text that would ideally serve to dispel some of the myths. As of November 2014, all these publications have been available and free to download, which has considerably improved their accessibility in the relevant regions as well as for universities around the globe. The seven publications have been downloaded some 18,000 times in less than two years.

On balance, we can identify three related challenges in the first three steps of the IHJR theory of change, based on several internal reports and the project documentation gathered over the years. First of all, the IHJR had to run many of these projects in the face of significant resource and capacity constraints. Con-

39 For an overview of similar initiatives see R. Nets-Zehngui, "Palestinians and Israelis Collaborate in Addressing the Historical Narratives of their conflict," Quest Issues in Contemporary Jewish History, 5 (2013): 238-243.

40 Hassan Mwakimako and George Gona, eds., IDP's Narratives as Political Discourses of Identity. Interviews with Internally Displaced Persons In Kenya Resulting from the PostElection Violence of 2007-2008 (The Hague: Institute for Historical Justice and Reconciliation, 2011).

41 See, http://historyandreconciliation.org/our-work/projects/israel-palestine/, accessed 12 November 2017.

42 S. Mirzoyan and C. Badem, eds., The Construction of the Tiflis-Aleksandropol-Kars Railway (1895-1899) (The Hague: Institute for Historical Justice and Reconciliation, 2013).

43 D. Gavrilovic and P. Vjekoslav, eds., Political Myths in the Former Yugoslavia and Successor States (Dordrecht: Institute for Historical Justice and Reconciliation and Republic of Letters Publishing, 2011). 
vening scholars with opposing agendas in particular proves to be highly resource-intensive. Disputed historical legacies are by definition sensitive between and within communities and countries. The delicate nature of the work resulted in real or perceived repercussions for scholars and the IHJR. Scholars were sometimes actively discouraged from participating or even forced to withdraw. In other cases, political considerations dictated the extent to which sensitive myths might be addressed or where project meetings could be held. Nevertheless, quite possibly the most important challenge concerned the impact the IHJR was hoping to achieve - and indeed was required to demonstrate by its donors.

The second challenge followed on from the first. The necessity that the IHJR coach and guide the participating scholars intensively during the process meant that the Institute was obligated to focus a great deal of attention on fostering interpersonal group dynamics. Guiding a group of scholars working on publications based on a radically different approach to historical research meant less capacity to develop and integrate an active dissemination strategy. A possible explanation for this might be that the IHJR developed the work - on the historians' initiative - within civil society rather than at the political level. Early attempts to engage at the political level underscored the difficulty of maintaining objective positions free of political influence, both for the IHJR staff and for those participating in the project work.

The limited space for the dissemination of results subsequently diminished the ability of the IHJR to achieve its desired broad social impact. As a result, the IHJR decided to maintain a low profile and remain independent in order to assure that the process of reaching a shared narrative was not negatively impacted. While this proved effective with regard to the joint working processes, it impeded the dissemination process in the later stages, as the IHJR had to rely on partners who had not participated in the initial research effort. Confronted with a limited track record at civil-society level, for example, the Institute might potentially have struggled to develop a fully-fledged dissemination strategy in parallel with its joint narrative work that would not negatively impact the writing process.

\section{The Education Challenge, Phase II (Steps 4 to 7 of the Theory of Change)}

In 2013, the IHJR carried out an exercise in order to assess the accomplishments and challenges of its work. Having concluded seven shared-narrative publications by that time, the IHJR decided to take a step back and reflect on its 
approach and strategy. As a result of this exercise, the IHJR identified several main lessons. While there was a sense that the approach offered by the Institute was much in demand, its project design did not allow it to sufficiently drive a change in attitudes and to combat (mis)perceptions of history in society at large. The principal challenge was perhaps that the question of identifying the target audience had not yet been decisively addressed. As part of the exercise, the IHJR team discussed whether the strategy might focus on building a network of scholars or whether the organization should consider other alternatives to maximize the impact of its work. The results from a range of interviews conducted with board members, external stakeholders, staff, and project participants suggested that, while the IHJR ultimately aimed to promote reconciliation in societies by convening historians to participate in its projects, the Institute was only successfully reaching academic and student audiences. While there was general agreement that the IHJR should retain the role of historians in its work, the need to invest more heavily in its educational development and outreach aspects was also considered important.

In sum, the work of the IHJR needed to be seen as part of a broader societal response to addressing the legacies of the past, and it sought to become embedded within wider-reaching educational measures in this regard. ${ }^{44}$ As noted by Ramírez-Barat and Roger Duthie in a recent report on Education and Transitional Justice, "once the conflict or repression comes to an end, ... education can be an important vehicle for remembering the past, facilitating the transmission of memory, and contributing to the promotion of peace. Because of its formative potential, education can help to shape new norms, mediate between contending narratives of the past, and nurture a culture of respect for human rights across generations." ${ }^{\prime 5}$ From 2014 onwards, the primary challenge facing the IHJR thus became effectively building bridges between the scholars producing shared narratives and the partners in the education sector who would assist in turning that research into products of social value. Shared narratives would thus be converted into socially impactful "products," first and foremost for the purposes of history education, and seek a closer alignment with transitional justice initiatives.

In the strategic evaluation, young people were identified as the target group to gain the most from IHJR interventions. On many levels, the mission and vision of the Institute had promoted youth engagement from the outset, and the importance of involving them in such programs is generally underlined in peace education literature. ${ }^{46}$ The IHJR's strategic plan of 2014 noted that the Institute

44 C. Ramírez-Barat and R. Duthie, Education and Transitional Justice, 2.

45 Ibid., 11.

46 See, for example, D. Bar-Tal and Y. Rosen, "Peace Education in Societies Involved in In- 
had to "correct this shortcoming and ensure that youth are efficiently and professionally reached." ${ }^{\prime 7}$ To a certain extent, this was a continuation of the approach already taken for the publication $\mathrm{Zoom} \mathrm{In.}{ }^{48}$ As part of the IsraelPalestine project, IHJR had worked with Israeli and Palestinian students on interpreting images from $1948 .^{49}$

In order to connect with younger generations, education, and in particular history education at high school and university level, is a clear and unambiguous choice. Indeed, there is an emerging academic trend supporting the powerful impact that education may have on societies transitioning out of conflict. As Cole has argued, "one place where history becomes more concrete and relevant to non-elites is in schools: in history classrooms but also in related subjects." ${ }^{50}$ At the same time, high-school history education is a highly conservative area of education, one that is often affected by political agendas seeking to prevent sensitive discussions. The IHJR began to discuss the notion of having historians involved in its projects work directly with students in order to discuss and debate their personal histories. They would then also use their historical expertise in talks to find commonality among students with diverse histories, allowing the other to be rehumanized in real-time discussions of historical myths. ${ }^{51}$

As a result, the IHJR decided to focus on redesigning its educational outreach capacity in three ways. In May 2014, the IHJR established an institutional partnership with the Faculty of Humanities of Leiden University in the Netherlands. This partnership sought to develop projects of mutual benefit for both the university and the institute, and to establish a course based on the methodology of the IHJR as well as on the core academic readings on transitional justice and reconciliation. The course, entitled "Collective Memory: A Shared Historical Narrative in Reconciliation?" was taken by 40 students from diverse backgrounds.

The second step was the establishment of a partnership with the European Association of History Educators (EUROCLIO). EUROCLIO agreed to work with the IHJR in December 2013, and allowed it to tap into its network of experienced educators and teacher-training solutions in order to mainstream the shared-

tractable Conflicts: Direct and Indirect Models," Review of Educational Research 79, no. 2, (2009): 557-575.

47 IHJR Strategic Plan (The Hague, IHJR, 2014), 6. Document on file with authors.

48 S. Adwan et al., Zoom In: Palestinian Refugees of 1948, Remembrances (Dordrecht: Republic of Letters Publishing, 2011). For more information see http://historyandreconciliation.org/ resources/publications/zoom-in/, accessed September 2017.

49 IHJR, Strategic Plan, 6.

50 E. Cole, “Transitional Justice and the Reform of History Education,” 120. See also C. RamírezBarat and R. Duthie, Education and Transitional Justice.

51 See J. Halpern and H. Weinstein, "Dehumanizing the Other: Empathy and Reconciliation," Human Rights Quarterly, 26, no. 3 (2004): 561-583. 
narrative approach. By 2014, EUROCLIO was already a key partner in developing the IHJR project "Depolarizing the Past"52 (see box below).

A final way in which the IHJR developed its new strategy became discernable in the above-mentioned project "Depolarizing the Past." This was the first IHJR project in which students with diverging narratives were asked directly to share their personal histories and listen to academic experts speak on the historical controversies. The aim of this project was to recognize, as noted by Alan McCully, that "listening to personal accounts, genuinely told, makes history meaningful and influences beliefs or behaviors in the present based on what is learned from the past." 53

\section{Case II. Depolarizing the Past (Examples of Steps 4 and 5 of the Theory of Change)}

In the wake of the attack on the Charlie Hebdo office in early 2015 and protests in the Netherlands and elsewhere against Israelis in Western Europe, the IHJR launched a dialogue initiative among particularly disenfranchised youth in Western Europe in November 2015. The key objective of this project was to create greater understanding and contact between communities on "imported conflicts" such as the Armenian Genocide question and tensions between Israel and Palestine, two areas of expertise at the IHJR. To achieve this ambitious objective, the IHJR held five informal dialogue meetings and public events in Rotterdam on the historical conflicts between Armenia and Turkey, and Israel and Palestine.

The fourth step of the IHJR theory of change is exemplified in this project. The focus was entirely on local actors: university professors, history teachers, and student organizations. Historians from Leiden University were invited to take part together with representatives from Armenian and Turkish student organizations. They were asked to first jointly discuss the needs within their respective communities. At the public event, the results of these informal closed-door consultations were shared. This significantly strengthened the capacity of the students to act as champions of dialogue and build networks between Armenian and Turkish communities that had previously not existed.

The project also built on existing networks within the Armenian and Turkish communities that perfectly illustrate the fifth step of the IHJR theory of change. Existing networks of engaged citizens from academia, civil society and the media use the work of the IHJR to confront the prevailing stereotypes and historical myths. In informal meetings, personal oral histories were used to draw out the specific nature of young people's experiences. The IHJR created a steering group of community leaders that also significantly advanced the project.

52 The term derives from Alexander Karn's seminal article on joint historical commissions; see note 27.

53 Alan McCully, "History Teaching, Conflict and the Legacy of the Past," Education, Citizenship and Social Justice 7 (2012): 156. 
During the implementation of the project, the IHJR focused the discussions with Armenian and Turkish students on their personal family histories, with a view to connecting the latter with the prevailing narratives in their communities about the events of 1915. Facilitated by two scholars with expertise on the fall of the Ottoman Empire and on Armenian diaspora communities, as well as a history teacher, the participants were faced with ambivalence (i.e. not all Armenians were directly exposed to the genocide, and not all Turkish people were either perpetrators or bystanders). The project sought to encourage the students to truly involve themselves in the history of the other and to endeavor to understand his or her perspective. This ultimately led to some emotional openness and yet also curiosity on both sides. Students and high-school teachers alike returned with a more nuanced, less dualistic understanding of the ways in which communities perceive the events of 1915 , events that have dominated relations between these two peoples for decades.

\section{Conclusion}

In this chapter we have sought to explain and discuss the approach taken by IHJR in the field of historical justice and reconciliation since its foundation in 2004. We have explored the origins and debates surrounding its work using the seven steps of its theory of change. The theoretical section of the chapter has examined in more detail the mission of the IHJR to foster reconciliation between and within societies, and explained the tensions between different notions of reconciliation and the role historians and experts are expected to adopt when working on such projects. An important conclusion drawn in this chapter is that this theoretical tension was to some extent borne out in the practice of the IHJR. In the section on the implementation of the IHJR theory of change we have endeavored to demonstrate how the IHJR has been able to transition from a research-driven organization to one with an approach incorporating educational outcomes. We have depicted the journey of the IHJR, one that began with a focus on research and has evolved into a mission to build bridges between education, historical research, and the promotion of peace. Further, this chapter also demonstrates that a dialogue between scholars and young people from antagonistic communities that combines the best of personal histories with insights from firstrate research may well be a powerful way to bring about genuine empathy, understanding and stability in post-conflict societies. 


\section{Bibliography}

Adwan, S., E. Ben-Ze'ev, M. Klein, I. Saloul, T. Sorek, and M. Yazbak. Zoom In: Palestinian Refugees of 1948, Remembrances. Dordrecht: Republic of Letters Publishing, 2011. http://historyandreconciliation.org/resources/publications/zoom-in/.

Barkan, E. and T. Ryback. “A \$12 Billion History Lesson.” International Herald Tribune, 25 February, 2008.

Barkan, E. "Introduction: Historians and Historical Reconciliation." The American Historical Review 114, no. 4 (2009): 899-913.

Bar-Tal, D. and Y. Rosen. "Peace Education in Societies Involved in Intractable Conflicts: Direct and Indirect Models." Review of Educational Research 79, no. 2 (2009): 557-575.

Bevernage, B. "Transitional Justice and Historiography: Challenges, Dilemmas and Possibilities." Macquarie Law Journal 13 (2014): 7-24.

Bloomfield, D. "Reconciliation: An introduction." In Reconciliation after Violent Conflict: A Handbook, edited by D. Bloomfield, T. Barnes and L. Huyse, 10-18. Stockholm: International IDEA, 2003.

Borer, T. A. “Truth Telling as A Peace-building Activity: A Theoretical Overview.” In Telling the Truths: Truth Telling and Peace Building in Post-Conflict Societies, edited by T.A. Borer, 1-57. Notre Dame: University of Notre Dame Press, 2006.

Clark, H. and D. Taplin. Theory of Change Basics: A Primer on Theory of Change. New York: Actknowledge, 2012.

Clark, P. "Establishing a Conceptual Framework: Six Key Transitional Justice Themes." In After Genocide: Transitional Justice, Post-Conflict Reconstruction and Reconciliation in Rwand a and Beyond, edited by P. Clark and Z. K. Kaufman. London: Oxford University Press, 2008.

Cole, E. “Transitional Justice and the Reform of History Education." International Journal of Transitional Justice 1, no. 1 (2007): 115-137.

Crocker, D. A. "Reckoning with Past Wrongs: A Normative Framework." Ethics and International Affairs 13, no. 1 (1999): 45-62.

Gavrilovi, D. and P. Vjekoslav, eds. Political Myths in the Former Yugoslavia and Successor States. Dordrecht: Institute for Historical Justice and Reconciliation and Republic of Letters Publishing, 2011.

Golani, M. and A. Manna. Two Sides of the Coin: Independence and Nakba 1948. Two Narratives of the 1948 War and its Outcome. Dordrecht: Institute for Historical Justice and Reconciliation and Republic of Letters Publishing, 2011.

Halpern, J. and H. Weinstein. "Rehumanizing the Other: Empathy and Reconciliation." Human Rights Quarterly, 26, no. 3 (2004): 561-583.

Huyse, L. "The Process of Reconciliation." In Reconciliation after Violent Conflict. A Handbook, edited by D. Bloomfield, T. Barnes and L. Huyse, 19-32. Stockholm: International IDEA, 2003.

ICTJ. “Does Collective Remembrance of a Troubled Past Impede Reconciliation?" https:// www.ictj.org/debate/remembrance/opening-remarks.

IHJR. IHJR Vision Document. The Hague: IHJR, 2009. Copy on file with authors.

IHJR. IHJR Internal Report. The Hague: IHJR, 2013. Copy on file with authors.

IHJR. IHJR Strategic Plan. The Hague: IHJR, 2014. Copy on file with authors. 
Karn, A. M. "Depolarizing the Past: The Role of Historical Commissions in Conflict Mediation and Reconciliation." Journal of International Affairs 60, no. 1 (2006).

Korostelina K. V. and S. Lässig, eds. History Education and Post-Conflict Reconciliation: Reconsidering Joint Textbook Projects. New York and Oxon: Routledge, 2013.

Maier, C. S. "Doing History, Doing Justice: The Narrative of the Historian and of the Truth Commission." In Truth v. Justice: The Morality of Truth Commissions, edited by R. I. Rotberg and D. Thompson, 261-278. Princeton: Princeton University Press, 2000.

Maier, C. S. "Overcoming the Past? Narrative and Negotiation, Remembering and Reparation: Issues at the Interface of History and the Law." In Politics and the Past. On Repairing Historical Injustices, edited by J. Torpey. Lanham: Rowman \& Littlefield Publishers, 2003, 295-305.

McCully, A. "History Teaching, Conflict and the Legacy of the Past." Education, Citizenship and Social Justice 7 (2012): 145-159.

Mirzoyam, S. and C. Badem, eds. The Construction of the Tiflis-Aleksandropol-Kars Railway (1895-1899). The Hague: Institute for Historical Justice and Reconciliation, 2013.

Mwakimako, H. and G. Gona, eds. IDP's Narratives as Political Discourses of Identity: Interviews with Internally Displaced Persons in Kenya Resulting from the Post-Election Violence of 2007-2008. The Hague: Institute for Historical Justice and Reconciliation, 2011.

Nets-Zehngut, R. "Palestinians and Israelis Collaborate in Addressing the Historical Narratives of their Conflict." Quest: Issues in Contemporary Jewish History 5 (2013): 238-243.

Neumann, K. "Historians and the Yearning for Historical Justice." Rethinking History: The Journal of Theory and Practice 18, no. 2 (2014): 145-164.

Ramírez-Barat, C. and R. Duthie, Education and Transitional Justice: Opportunities and Challenges for Peacebuilding. New York, International Center for Transitional Justice and UNICEF, 2015.

Rigney, A. "Reconciliation and Remembering: (How) does it work?" Memory Studies 5, no. 3 (2012): 251-258.

Ryback, T. "Enter the Historians, Finally." International Herald Tribune, 23 November, 2006.

Tint, B. "History, Memory, and Intractable Conflict." Conflict Resolution Quarterly 27, no. 3 (2010): 239-256.

Tutu, D. No Future without Forgiveness. New York: Doubleday, 1999.

Wouters, N. "The Use of History in the Field of Transitional Justice: A Critical Introduction.” In Transitional Justice and Memory in Europe (1945-2013), edited by N. Wouters, 1-25. Cambridge: Intersentia, 2014. 


\section{About the Authors}

Najwa Belkziz is a Fulbright scholar and sessional lecturer at the University of Melbourne, Australia. She is also an associate editor of the Melbourne Historical Journal. Her research interests include oral history, memory, transitional justice, and the historiography of the Middle East and North Africa. She completed a $\mathrm{PhD}$ in history at the University of Melbourne and holds a master's degree in international affairs from Columbia University. Najwa Belkziz has extensive experience working on issues of good governance, education, and human rights in the MENA region.

Denise Bentrovato is a research fellow of the Department of Humanities Education at the University of Pretoria and co-director of the African Association for History Education (AHE-Afrika). Her research combines an interest in postconflict memory politics, transitional justice, and history education, and primarily focuses on Africa. Throughout her career she has combined scholarship and practice in peacebuilding, education, and youth projects, working both in academia and for international organizations and NGOs, including UNESCO, the Inter-Agency Network for Education in Emergencies (INEE), and the Georg Eckert Institute for International Textbook Research (GEI). Denise Bentrovato holds a PhD in international and political history from the University of Utrecht and an MA in conflict resolution from the University of Bradford. Her most recent publications include Narrating and Teaching the Nation: The Politics of Education in Pre-and Post-Genocide Rwanda (2015), History Can Bite: History Education in Divided and Postwar Societies (with K. Korostelina and M. Schulze, eds., 2016), and Learning to Live Together in Africa through History Education: An Analysis of School Curricula and Stakeholders' Perspectives (2017).

Jasmina Brankovic is a senior researcher with the Centre for the Study of Violence and Reconciliation, South Africa, and the associate editor of the International Journal of Transitional Justice. She is a $\mathrm{PhD}$ candidate in political studies at the University of Cape Town, and her research interests include context-re- 
sponsive approaches to transitional justice, the role of civil society in shaping the field, and the intersection of transitional justice and socioeconomic transformation. Her publications include Advocating Transitional Justice in Africa: The Role of Civil Society (2018) and The Global Climate Regime and Transitional Justice (2018).

Ruben Bücking is a historian and a former research assistant of the Institute for Historical Justice and Reconciliation (IHJR). He currently organizes training seminars on dealing with the past, depolarization, and reconciliation aimed at educators and youth workers in the Caucasus region. He holds a master's degree in modern history and international relations from the University of Groningen. His research interests include dealing with the past, transitional justice and reconciliation, and the possible roles of historiography therein.

Sara Clarke-Habibi completed her PhD in education at the University of Cambridge in 2017 as a Gates Cambridge scholar. She also holds an MPhil in education research from Cambridge (2012), an MA in conflict resolution from Landegg International University (2002), and a BA in ethics, society and law from the University of Toronto (1999). For more than 15 years, Sara Clarke-Habibi has worked as a consultant and trainer with universities, schools, and civil-society organization in Bosnia-Herzegovina, Croatia, Israel-Palestine, Azerbaijan, Cyprus, Austria, Germany, Colombia, Mexico, Canada, Switzerland, and Ukraine on post-conflict peacebuilding initiatives, conflict-sensitive education reform, school development, and youth empowerment. She researches, teaches and advises internationally on the role of education in conflict transformation, transitional justice and dealing with the past, peacebuilding, social healing, and intergroup reconciliation. She is currently based in Switzerland.

Roger Duthie is Director of Research at ICTJ, where he has managed research projects examining how transitional justice relates to education, forced displacement, and development. His publications include Justice Mosaics: How Context Shapes Transitional Justice in Fractured Societies (2017, co-edited with Paul Seils); Transitional Justice and Education: Learning Peace (2016, co-edited with Clara Ramírez-Barat); Transitional Justice and Displacement (2012); and Transitional Justice and Development (2009, co-edited with Pablo de Greiff); as well as articles published in the International Journal of Transitional Justice and the International Human Rights Law Review. He also co-edited (with Megan Bradley) a special issue of the Journal of Refugee Studies on accountability and redress for displacement (2014). He has a BA in history from Cornell University and an MA in international relations from Yale University. 
Stefana Fratila is a Romanian-born scholar and sound artist based in Toronto, Canada. Since 2012, she has been composing for dance and theatre as well as creating sound pieces for public gallery spaces, including "december 6th 1989" (in memory of the women killed twenty-eight years ago at École Polytechnique in Montréal) and "no history" (written as a gesture of bearing witness to ongoing colonial violence and as an enactment of settler-shame). She recently finished her master's degree in political science at UBC on unceded $x^{\mathrm{w}}$ mə $\theta \mathrm{k}^{\mathrm{w}} \partial y$ ým (Musquem) territories, focusing on how sound and performance can be used to critically engage in and educate on historical as well as ongoing colonial violence prevalent in settler-colonial society.

Daniel Haumschild is the Holocaust Education Fellow at Cardinal Stritch University and the Nathan and Esther Pelz Holocaust Education Resource Center in Milwaukee, Wisconsin. He also serves as a lecturer in the Honors College at the University of Wisconsin-Milwaukee. His work responds to contemporary social and political phenomena by employing the disciplines of philosophy and critical theory. He holds a PhD in comparative literature from the University at Buffalo (SUNY) and has been the recipient of numerous grants and scholarships that have enabled his field work in Rwanda and the Great Lakes region. His current research addresses the relationship between public history and reconciliation in communities that have experienced mass violence.

Clara Ramírez-Barat is director of the educational policies program at the Auschwitz Institute for Peace and Reconciliation. Before joining the Auschwitz Institute, she was a senior research associate at the International Center for Transitional Justice (ICTJ), where she worked for more than four years after having served for two years as a Fulbright postdoctoral fellow. At ICTJ, her research focused on various aspects of transitional justice with a particular interest in outreach, media, and the cultural sphere. More recently, Clara Ramírez-Barat has worked at the intersection of transitional justice and education, both by developing a child-friendly version of the Kenyan Truth Commission's final report and as part of a broader two-year research project on transitional justice, education, and peacebuilding. Born in Madrid, Spain, she obtained her $\mathrm{PhD}$ in 2007 from the University Carlos III of Madrid with a thesis on transitional justice, and holds an MA in philosophy from Columbia University (2002). She is currently based in São Paulo, Brazil.

María Andrea Rocha is coordinator of the pedagogical team of the National Center for Historical Memory (Centro Nacional de Memoria Histórica) in Bogotá, Colombia. Since 2013 she has been involved in the design of strategies to generate social appropriation of and public debate about Colombia's recent 
history. Among these strategies is a teacher's toolbox that facilitates learning and classroom discussion about Colombia's violent past. María Andrea Rocha completed her master's degree in political science at Andes University in Bogotá. Her research interests include armed conflict, peacebuilding, transitional justice, and education.

Martina Schulze is head of the International Office at Hamburg University of Applied Sciences. She was academic program coordinator of the Georg Arnhold Program on Education for Sustainable Peace and coordinator of international affairs at the Georg Eckert Institute (GEI) from May 2013 to September 2016. Before joining the GEI, she worked for more than 15 years as a cultural affairs specialist for the US Consulate General in Hamburg and as an educational advisor at the Amerika Haus Hamburg. She holds an MA in international relations from Boston University and an MA in American studies and history from the University of Hamburg.

Nadia Siddiqui is a co-founder and researcher at Social Inquiry, an Iraq-based not-for-profit institution focused on influencing policy and praxis. The organization seeks to establish civic trust and repair the social fabric within and between fragile communities, and between communities and the state. She also helped form the Applied Theatre Collective, which seeks to establish creative space for dialogue through the arts. Her work focuses on the intersections of cultural practice, social dynamics, and justice. Previously, Nadia Siddiqui has worked with a number of international and intergovernmental organizations on research and programming related to transitional justice, social cohesion, policy advocacy, strategy, and design. She holds a BA (Honors) in psychology from the University of Michigan and a MSc in evidence-based social intervention from the University of Oxford.

Ties Olivier Schelfhout is the former executive director of the Institute for Historical Justice and Reconciliation (IHJR) and now works as policy advisor for international affairs at the City of The Hague. His main fields of interest include transitional justice, peacebuilding and education, and conflict prevention. $\mathrm{He}$ holds an MA in political science from Leiden University and an LLM in international and European law from the University of Amsterdam. Before joining the IHJR, he worked in various roles in both the public and private sectors, including on human rights, governance, and security issues. 